\title{
INFLUENCE OF INTERNAL COURTYARDS ON THE ENERGY LOAD AND HOURS OF ILLUMINANCE IN ROW HOUSES IN TORONTO
}

\author{
by \\ Germán Vaisman \\ Bachelors in Architecture \\ Universidad de Buenos Aires, 2011. \\ A Major Research Project \\ presented to Ryerson University \\ in partial fulfillment of the \\ requirements for the degree of \\ Master of Building Science \\ in the Program of \\ Building Science
}

Toronto, Ontario, Canada, 2015

(C) Germán Vaisman, 2015 


\section{Author's declaration}

I hereby declare that I am the sole author of this MRP. This is a true copy of the MRP, including any required final revisions.

I authorize Ryerson University to lend this MRP to other institutions or individuals for the purpose of scholarly research.

I further authorize Ryerson University to reproduce this MRP by photocopying or by other means, in total or in part, at the request of other institutions or individuals for the purpose of scholarly research.

I understand that my MRP may be made electronically available to the public. 


\title{
INFLUENCE OF INTERNAL COURTYARDS ON ENERGY LOAD AND HOURS OF ILLUMINANCE IN ROW HOUSES.
}

\author{
Master of Building Science 2015 - Germán Vaisman \\ Building Science Program - Ryerson University
}

\section{Abstract}

Natural daylight is desirable in locations where winter days are short. With narrow front and long depth, row houses interiors in Toronto tend to be dark, as natural light cannot penetrate to the central portion of the house. This study aims to contribute to the development of guidelines for designers using courtyards to create better space quality and to add to occupants' delight, health and wellbeing. It examines the potential benefits and drawbacks of internal courtyards in houses located in cold climates and the implications of such design on the energy performance, natural light and lighting consumption. The simulations showed that the window to wall ratio doesn't have major influence on the hours of daylight inside the house. The main results also show significant improvement of the hours of illuminance in the interior, with higher increases in the shorter days of the year when light is more needed. 


\section{Acknowledgement}

I want to thank to my supervisor Dr. Miljana Horvat for her constant advise, support and encouragement. I would also like to thank my second reader Dr. Mark Gorgolewski for all his guidance before and throughout the school year.

I want to thank my friends and colleagues at Ryerson University for sharing their time and feedback.

It is important for me to acknowledge and share how grateful I am with Canada, for giving me the opportunity to learn and become part. It's been an exciting and fulfilling journey than could not have been possible without the support of this wonderful country. Thank you Canada.

And to my family. To my brothers and my parents for their love and support. And to my love and companion of life, Federico, who has been by my side all this time. 
Table of Contents

AUTHOR'S DECLARATION II

ABSTRACT III

ACKNOWLEDGEMENT IV

Table of Contents ii

List of Figures $\quad v$

List of Tables viii

List of Acronyms $\quad$ ix

List of Units $\quad$ ix

1 INTRODUCTION 1

1.1 Motivation 1

1.2 Problem statement 2

1.3 Opportunities 3

2 LITERATURE REVIEW 4

2.1 Courtyards and row houses in history 4

$\begin{array}{lll}2.2 & \text { Courtyards as a protective configuration in cold climates } & 7\end{array}$

2.3 Internal courtyards in contemporary houses 9

$\begin{array}{lll}2.4 & \text { The row house archetype in Toronto } & 15\end{array}$

2.5 Energy performance of row houses with internal courtyards 22

2.6 Footprint and height of the courtyard 23

2.7 Hybrid system: Courtyard/atrium. 28

$\begin{array}{lll}2.8 & \text { Literature review summary } & 30\end{array}$ 
$\begin{array}{lll}3.1 & \text { Objectives } & 33\end{array}$

4 METHODOLOGY 34

$\begin{array}{lll}4.1 & \text { Existing house } & 34\end{array}$

$\begin{array}{lll}4.2 & \text { Base cases } & 36\end{array}$

$\begin{array}{lll}4.3 & \text { Layouts } & 37\end{array}$

4.4 Simulation model $\quad 40$

4.4.1 Envelope $\quad 42$

4.4.2 Weather file and run period $\quad 45$

4.4.3 Hours of illuminance 46

4.4.4 Internal loads: Lighting, appliances and people $\quad 47$

4.4.5 Equipment: Furnace, air conditioning and domestic hot water 47

4.4.6 Energy model verification 48

$\begin{array}{ll}4.4 .7 \text { Courtyard geometry and height } & 49\end{array}$

4.4.8 Window to wall ratio $\quad 50$

4.4.9 Orientation $\quad 55$

$\begin{array}{lll}4.5 & \text { Performance indicators } & 56\end{array}$

5 RESULTS $\quad 57$

$\begin{array}{lll}5.1 & \text { Benchmarks } & 57\end{array}$

$\begin{array}{lll}5.2 & \text { Base cases } & 58\end{array}$

$\begin{array}{lll}5.3 & \text { Energy use for the lights } & 61\end{array}$

5.3.1 Illuminance $\quad 62$

$\begin{array}{ll}\text { 5.3.2 Window to wall ratio } & 70\end{array}$

5.3.3 Total energy use of the row houses with courtyards 71

$\begin{array}{lll}5.4 & \text { Priority scales } & 79\end{array}$

$\begin{array}{lll}5.5 & \text { Design guidelines } & 85\end{array}$

$\begin{array}{lll}5.6 & \text { Summary of results } & 88\end{array}$

6 CONCLUSIONS 93

7 RECOMMENDED WORK FOR THE FUTURE 94 
8 APPENDICES 95

APPENDIX A - SOUTH ORIENTATION RESULTS 96

APPENDIX B - EAST ORIENTATION RESULTS 104

APPENDIX C - NORTH ORIENTATION RESULTS 112

APPENDIX D - WEST ORIENTATION RESULTS 120

$\begin{array}{ll}\text { APPENDIX E - ENERGY BILLS CALIBRATION } & 128\end{array}$

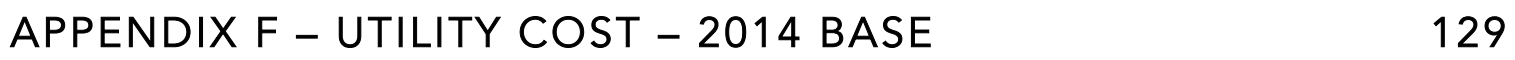

APPENDIX G - BUILDING CODE AND ZONING 130

APPENDIX H - EXISTING HOUSE 132

APPENDIX I - ILLUMINANCE INCREASE VS. HEATING AND COOLING ENERGY INCREASE

9 REFERENCES

135 


\section{List of Figures}

FIGURE 1: ALVAR AALTO'S SÄYNÄTSALO TOWN HALL. INTERIOR COURTYARD FROM THE INTERIOR OF THE BUILDING. (KPANEN, M., ALVAR AALTO MUSEUM, N.D.) .................. 1

FIGURE 2: ALVAR AALTO'S SÄYNÄTSALO TOWN HALL PLAN. (TEITTINEN, U., ALVAR AALTO

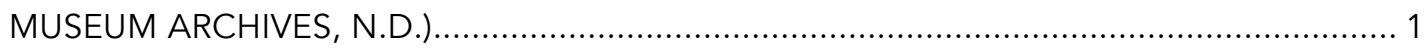

FIGURE 3: RETROFITTED ROW HOUSE IN TORONTO (SHAPTON, 2014) ................................ 2

FIGURE 4: ALVAR AALTO'S SÄYNÄTSALO TOWN HALL. EXTERIOR VIEW. (MOSER, L., ALVAR AALTO MUSEUM, N.D.).

FIGURE 5: INTERIOR COURTYARD IN A HOUSE IN BUENOS AIRES, ARGENTINA. (VAISMAN,

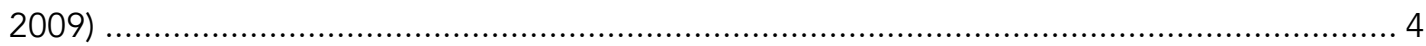

FIGURE 6: TYPOLOGICAL PROCESS OF A COURTYARD HOUSE (PETROCCIOLI, 2006) ........... 5

FIGURE 7: MIDDLE AGE ROW HOUSE IN CHESTER, UK. (FRIEDMAN, 2012) ......................... 6 FIGURE 8: RESIDENCE ANDALOUS IN SOUSSE, TUNISIA. SERGE SAUTELLI (ÖZKAN, 2005) .... 6 FIGURE 9: INTERNAL COURTYARD AND GLAZED BALCONIES BUILDINGS IN HARBIN, CHINA.

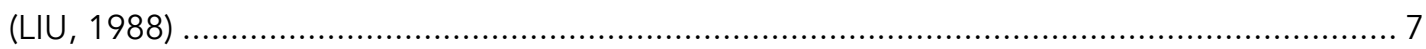

FIGURE 10: FARM IN DALARNA, NORWAY. 1926. (CUJLAT ET AL, 1988).............................. 8

FIGURE 11: ØSTGÅRD, NORWAY. FARM AND VILLAGE. (CULJAT ET AL, 1988). ..................... 9 FIGURE 12: THE "LUNG" PATTERN USED IN FINNISH NEIGBOURHOOD PLANNING IN THE 1960'S. SOURCE: OLLI KIVINEN, HÄMEENLINNA GENERAL PLAN, 1957. (MÄNTY, 1998) 9

FIGURE 13: COURTYARDS USED TO SEPARATE THE KITCHEN FROM THE LIVING AREA AND THE ROOM. WEEKEND HOUSE. TOKYO, 1998. RYUE NISHIZAWA. (PFEIFER \&

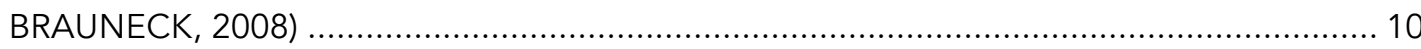

FIGURE 14: THE INTERNAL COURTYARD IS USED TO SEPARATE THE KITCHEN FROM THE DINING ROOM. GROUP OF HOUSES "KLEINE RIETEILAND". AMSTERDAM, 2004.

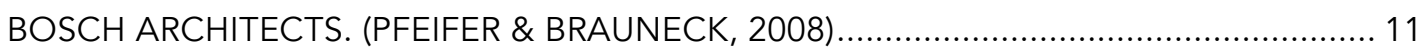

FIGURE 15: NO EXPOSURE TO THE STREET. THE COURTYARD IS THE MAIN CONNECTION WITH THE EXTERIOR. "MACHIYA" HOUSE. DAITA, JAPAN. KAZUNARI SAKAMOTO.

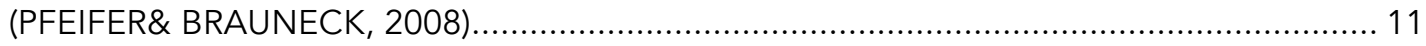

FIGURE 16: SLICE HOUSE, PORTO ALEGRE, BRAZIL. BY PROCTER-RIHL ARCHITECTS. 2005.

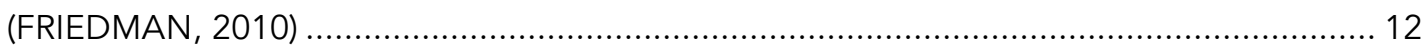

FIGURE 17: HOUSE WITH AND INTERNAL COURTYARD IN NORWAY . (SNØHETTA, 2014 .... 12

FIGURE 18: MECHANICAL SCHEME OF A HOUSE WITH A COURTYARD IN NORWAY.

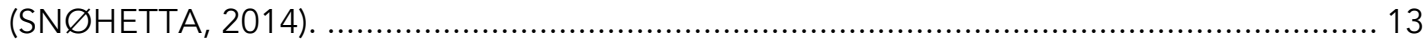

FIGURE 19: SINO-ITALIAN ECOLOGICAL AND ENERGY EFFICIENT BUILDING. BEIJING,

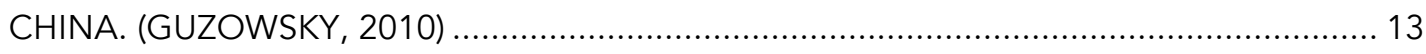

FIGURE 20: INTERNAL COURTYARD IN A ROW HOUSE IN MONTREAL. 2014. (FORTIN, 2014)

FIGURE 21: ROW HOUSE BUILDINGS COVERAGE AVERAGES 60\% OF THE AVAILABLE LAND.

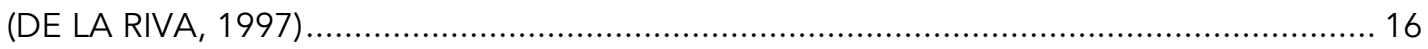

FIGURE 22: ROW HOUSES AT 24 MCGILL ST, TORONTO. YOU CAN SEE THE SIDE SETBACKS ON THE REAR OF THE HOUSE.

FIGURE 23: ROW HOUSES IN TORONTO LOCATED AT 486 SHAW ST. WITH 4.2M WIDE LOTS.

FIGURE 24: ROW HOUSE PLAN FROM 1887 IN JARVIS ST., TORONTO. (WARD, 1999) ........... 18 
FIGURE 25: (A) INTERIOR AND (B) EXTERIOR. LANEWAY HOUSE. SUPERKÜL STUDIO.

(SUPERKÜL, 2014)

FIGURE 26: ROW HOUSE WITH AN INTERNAL COURTYARD LOCATED IN TORONTO. (DWELL, 2014)

FIGURE 27: (A) (B) ROW HOUSE WITH AN INTERNAL COURTYARD LOCATED IN TORONTO (SHAPTON, 2014).

FIGURE 28: FLOOR TO SURFACE RATIOS: THE HIGHER THE RATIO THE LOWER THE ENERGY

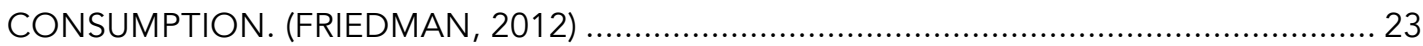

FIGURE 29: DAYLIGHT ENTERING THE HOUSE ACCORDING TO THE ORIENTATION. (FRIEDMAN, 2012)

FIGURE 30: SIDE GLAZED WINDOWS AND SKYLIGHTS. THIN FLATS. PHILADELPHIA,

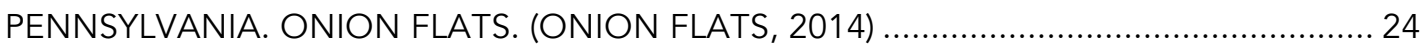

FIGURE 31: HIGHER AMOUNT OF SUN LIT CONFIGURATION. WITH A DECREASE OF $6.6 \%$ OF SUNLIT FOR EACH FLOOR ADDED. (MUHAISEN, 2006) ........................................... 25

FIGURE 32: EFFECT OF CHANGING THE ORIENTATION ON THE PERCENTAGE OF SURFACE

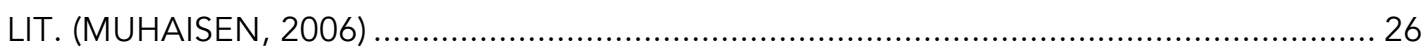

FIGURE 33: COURTYARD GLAZING PERFORMANCE AT 67\% SURFACE AREA IN TEMPERATE

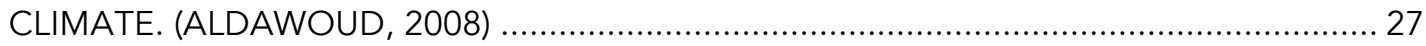

FIGURE 34: MODELS FOR THE ANALYSIS OF INTERNAL COURTYARDS IN THE

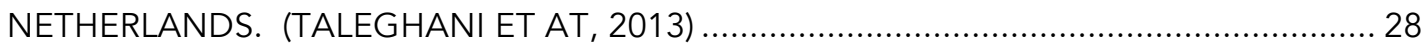

FIGURE 35: ELEVATIONS AND SECTION OF THE EXISTING HOUSE. UNITS ARE IN METERS. 35 FIGURE 36: PLANS AND ELEVATIONS OF THE EXISTING HOUSE. UNITS ARE IN METERS..... 36

FIGURE 37: BASE CASE MODEL BASED ON THE EXISTING HOUSES BUT WITHOUT AN

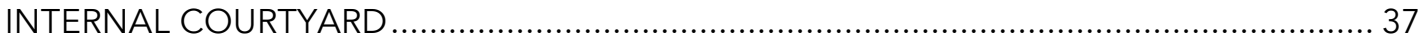

FIGURE 38: LAYOUT 2 - CLASSIC. BEDROOMS ARE IN THE UPPER FLOOR AND THE LIVING

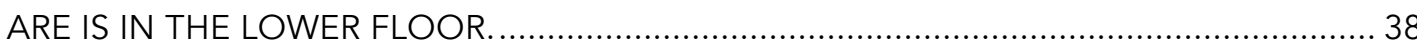

FIGURE 39: LAYOUT 1. THE BEDROOMS ARE LOCATED IN THE LOWER FLOOR AND THE LIVING AREA IS LOCATED THE UPPER LEVEL, AS IN THE EXISTING ROW HOUSE IN THE

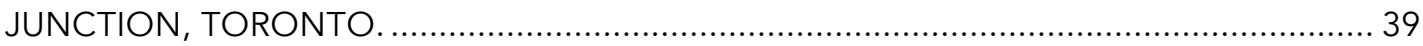

FIGURE 40: PREDICTED ANNUAL ENERGY USE AND COST OF THE EXISTING HOUSE. ........ 49

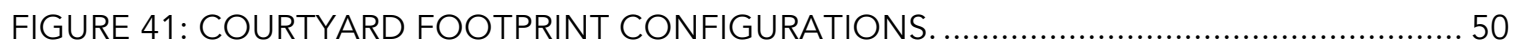

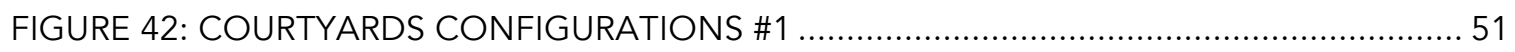

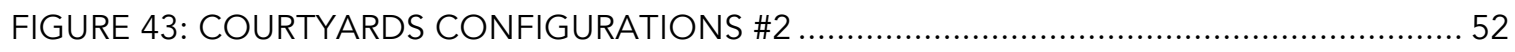

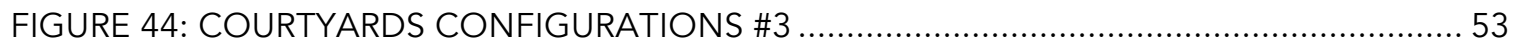

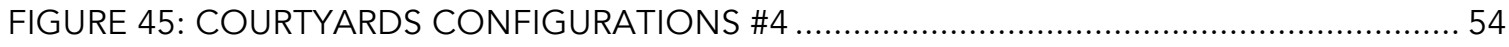

FIGURE 46: TYPICAL LOT ORIENTATIONS IN TORONTO (CITY OF TORONTO, 2014) ........... 55

FIGURE 47: EXISTING ROW HOUSE AND ADJACENT LOTS. (CITY OF TORONTO, 2014)....... 55

FIGURE 48: COURTYARD LOCATION AND LOT ORIENTATIONS USED IN THE ENERGY

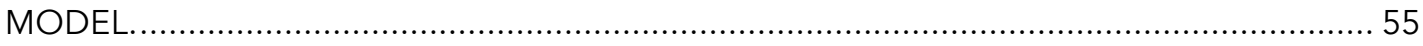

FIGURE 49: LOCATION OF SENSOR AT BASE CASES WITHOUT COURTYARD ….................. 59 FIGURE 50: INFLUENCE OF THE ENVELOPE SHAPE ON THE ENERGY LOADS IN WINTER ....60 FIGURE 51: ENERGY SAVED BY THE REDUCTION OF ENERGY USE IN ARTIFICIAL LIGHT. ... 61

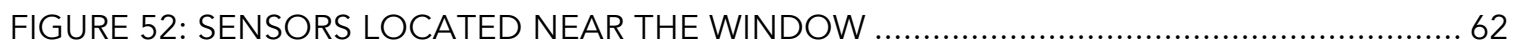
FIGURE 53: (A) (B) THE SENSORS NEAR THE WINDOWS DO NOT SHOW MUCH INCREMENT IN THE ILLUMINANCE HOURS WHEN THEY HAVE ALSO THE SOURCE OF THE INTERNAL COURTYARD. 
FIGURE 54: (A) SENSOR LOCATED IN THE MIDDLE OF TE FLOOR PLAN. (B) THE SENSOR IN THE CENTRE OF THE HOUSE SHOW HIGHER IMPROVEMENTS THAN THE ONES NEAR THE WINDOWS. .64

FIGURE 55: LOWER PERFORMER, OPTION 3-B NORTH SHOWING 329 MORE HOURS PER YEAR OR 9\% MORE THAN IT BASE CASE. 3-C AND 3-D HAVE LESS TIME THAN IT BASE CASE.

FIGURE 56: INCREASE IN THE AMOUNT OF HOURS OF NATURAL LIGHT COMPARED TO EACH BASE CASE. FROM HIGHER TO LOWER

FIGURE 57: SENSOR LOCATED FAR FROM THE LIGHT SOURCE IN COURTYARDS 3-C AND 3D.

FIGURE 58: BEST PERFORMER IN ILLUMINANCE: OPTION 1-A WEST SHOWING 714 MORE HOURS PER YEAR OR 20\% MORE THAN THE BASE CASE.

FIGURE 59: DIFFERENCE IN THE HOUR'S RANGE OF ILLUMINANCE BETWEEN THE HIGHEST AND THE LOWEST WWR FOR EACH COURTYARD ON EACH MONTH .......................... 70

FIGURE 60: HOURS OF ILLUMINANCE VS. ENERGY USE FOR COURTYARDS 1 WEST ........... 72

FIGURE 61: TOTAL ENERGY USE FOR HEATING AND COOLING. ORDERED FROM BEST TO WORST PERFORMER COMPARED TO THEIR BASE CASES.

FIGURE 62: TOTAL ENERGY USE FOR HEATING AND COOLING COMPARED TO THEIR BASE CASE

FIGURE 63: COMPARISON BETWEEN THE INCREASE IN ENERGY USE AND THE INCREASE IN THE ILLUMINANCE TIME. ORDERED FROM LOWER TO HIGHER ENERGY USE FOR HEATING AND COOLING 75

FIGURE 64: COMPARISON BETWEEN THE INCREASE IN ILLUMINANCE TIME AND ENERGY USE. ORDERED FROM HIGHER ILLUMINANCE INCREASE TO LOWER

FIGURE 65: ENERGY USE FOR HEATING AND COOLING OFFERED FROM LOWER TO HIGHER

FIGURE 66: BEST RESULTS IN 22 OF THE 24 PRIORITY SCALES ............................................. 80

FIGURE 67: HOURS OF ILLUMINANCE FOR THE BEST RESULTS ON PRIORITY SCALES ......... 81

FIGURE 68: ENERGY USE OF THE BEST RESULTS ON PRIORITY SCALES …......................... 81

FIGURE 69: 2014 UTILITY COSTS FOR THE BEST RESULTS ON PRIORITY SCALES .................. 81

FIGURE 70: EXAMPLE OF THE INFORMATION TO BE FOUND IN THE CHART ....................... 85 


\section{List of Tables}

TABLE 1: COMPARISON OF ENERGY INTENSITY USE BETWEEN THE MODELS. (TALEGHANI ET AL, 2013)

TABLE 2: BASE CASE. SB-12 PACKAGE A REQUIREMENTS AND SPECIFIED MATERIAL FOR THE WALL ASSEMBLY.

TABLE 3: CONSTRUCTION ASSEMBLIES___ 43

TABLE 4: WINDOWS SPECIFICATIONS

TABLE 5: WEATHER DATA REPORT FROM ENERGYPLUS. __ 45

TABLE 6: LIGHTS SCHEDULE AND INTENSITY __ 47

TABLE 7: SIMULATION RESULTS OF THE BASE CASES WITH THE NEIGHBOURING PROPERTIES 59

TABLE 8: SIMULATION RESULTS OF THE BASE CASE WITHOUT THE NEIGHBOURING PROPERTIES 59

TABLE 9: BEST PERFORMER 1-A. SUNRISE AND SUNSET TIME COMPARED TO THE TIME OF THE DAY WHEN THE SENSORS REACH 100 LUX. BETWEEN BRACKETS IS THE TOTAL AMOUNT OF HOURS THAT THE SENSORS REACH 100 LUX.

TABLE 10: PRIORITY SCALE RESULTS FOR THE SOUTH ORIENTATION 83

TABLE 11: PRIORITY SCALE RESULTS FOR THE EAST ORIENTATION. 83

TABLE 12: PRIORITY SCALE RESULTS FOR THE NORTH ORIENTATION. 84

TABLE 13: PRIORITY SCALE RESULTS FOR THE WEST ORIENTATION. 84

TABLE 14: SOUTH ORIENTATION INFORMATION CHART. 86

TABLE 15: EAST ORIENTATION INFORMATION CHART. 86

TABLE 16: NORTH ORIENTATION INFORMATION CHART. 87

TABLE 17: WEST ORIENTATION INFORMATION CHART. 87 


\section{List of Acronyms}

AFUE annual fuel utilization efficiency

CCHT Canadian Center for Housing Technology

GTA Greater Toronto Area

NRCan Natural Resources Canada

OBC Ontario Building Code

WWR window to wall ratio

CIBSE Chartered Institution of Building Services Engineers

IESNA Illuminating Engineering Society of North America

List of Units

kWh kilowatt hours

m meter

$\mathrm{m}^{2}$ square meter

$\mathrm{m}^{3}$ cubic meter

RSI thermal resistance; $\left(\mathrm{m}^{2} \cdot \mathrm{K}\right) / \mathrm{W}$

$\mathrm{U}$ thermal transmittance; $\mathrm{W} /\left(\mathrm{m}^{2} \cdot \mathrm{K}\right)$ 


\section{Introduction}

\subsection{Motivation}

Inherently, the row house archetype implies lower energy consumption as a result of sharing interior walls and consequently less exposed surfaces. In Toronto, the need of light generated a vernacular design that detaches the back end of the sidewall from the adjacent house. This configuration generates a bay of light and air within the middle of the row house. Older row houses make use of this configurations but it's almost inexistent in new builds. In contrast, the reduced exposed surfaces of a row house don't have enough area for windows, thus increasing the need of artificial lighting.

The centre of the row house is the location with lower levels of natural light, an issue often resolved with skylights and light wells. In hot climates, internal courtyards have been used to control light, temperature, to improve cross ventilation and as shaded exterior spaces. There are also examples of internal courtyards in colder locations like insome examples of vernacular and contemporary architecture in Scadinavia. The Säynätsalo Town Hall in Finland, designed by Finnish

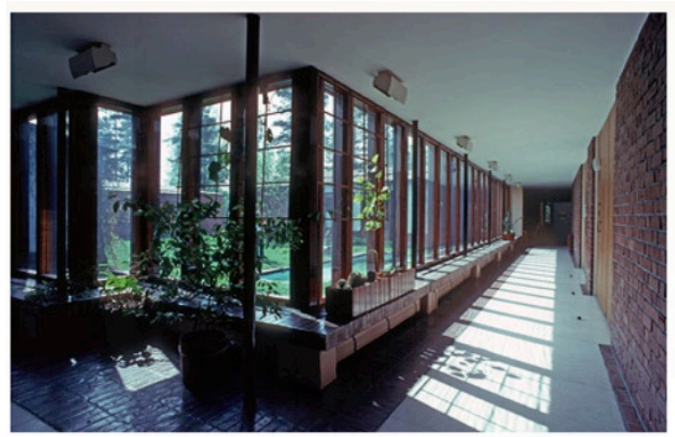

Figure 2: Alvar Aalto's Säynätsalo Town Hall. Interior courtyard from the interior of the building. (Kpanen, M., Alvar Aalto Museum, n.d.)

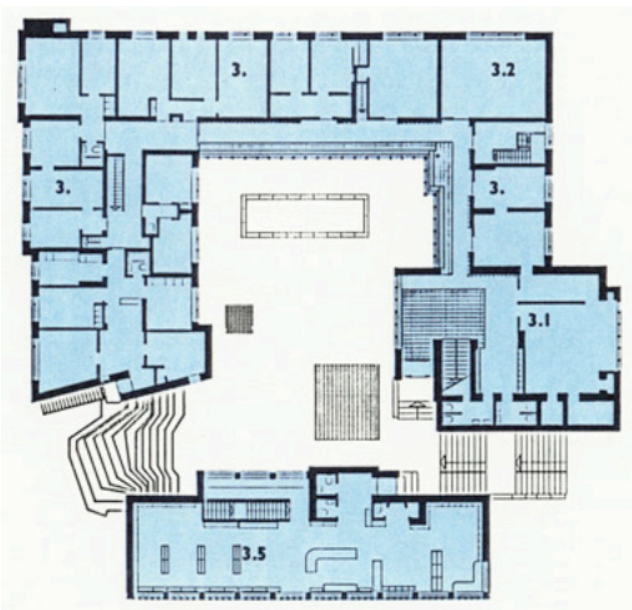

Figure 1: Alvar Aalto's Säynätsalo Town Hall plan. (Teittinen, U., Alvar Aalto Museum Archives, n.d.) 
architect Alvaar Alto, uses it the internal courtyard maximizing the light through orientation and window placement (Figure 2 and Figure 1). In this case the internal courtyard is used in a small public building stating the social importance of maximizing the incoming light in a location characterized with low temperatures and short days. Small and medium sized buildings are able to take advantage of the internal courtyard to maximize the incoming natural light.

\subsection{Problem statement}

Internal courtyards have been used in residential building on warm climate locations, but their residential use in cold climate regions has been limited (Figure 3). In Toronto, most of the newly built and retrofitted row houses only get good use of natural light close to the front and back windows, making the centre of the house a dark spot

throughout the day. Exposure to the sun is highly sought in places where winter days are short. It has been proved that the natural light is related to the

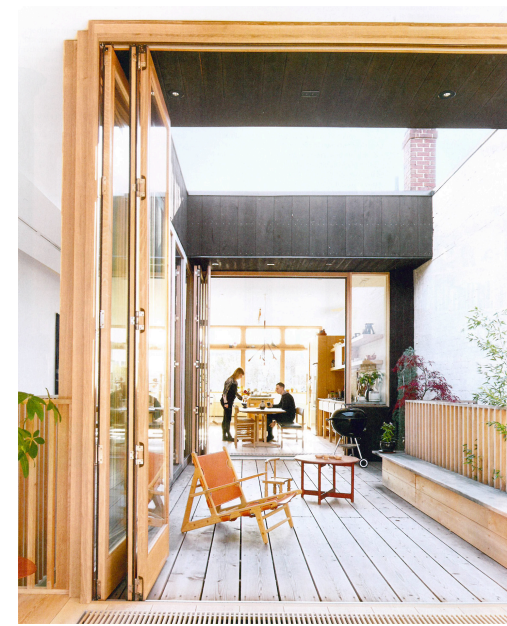

Figure 3: Retrofitted row house in Toronto (Shapton, 2014) wellbeing of the occupants. People are impacted by daylight, and it has been considered to improve the performance of workers and to help cure certain illness. Students in classrooms with natural light had also shown better performance that those in poorly lit ones (Edwards \& Torcellini, 2002). Newly built and retrofitted row houses have the opportunity to increase the interior natural light through layout design. In Canada, and more specifically in Toronto, internal courtyards are not commonly included in row houses. They could they be considered as a tool to increase the natural light inside the house. 
In the context of a high cost housing market in the Greater Toronto Area (GTA), row houses offer an affordable ownership option and a response to density increase. In highly populated cities, row houses use the internal courtyard as an accessible exterior space and to improve the interior light (Figure 3). What would be the implications of an internal courtyard in a row house? What would be the optimal geometry and orientation of that courtyard? Does the window to wall ratio have a major influence in the hours of illuminance and in the cooling and heating loads?

\subsection{Opportunities}

In Scandinavia, internal courtyards are used as exterior spaces that are protected from chilly winds and snow (Figure 4). In colder locations this archetype expands the use of exterior spaces throughout shoulder seasons (Borbe, 1988) and could be replicated to improve the interior lighting in a location like Toronto. It might also provide alternative heating sources through solar gains, and cross

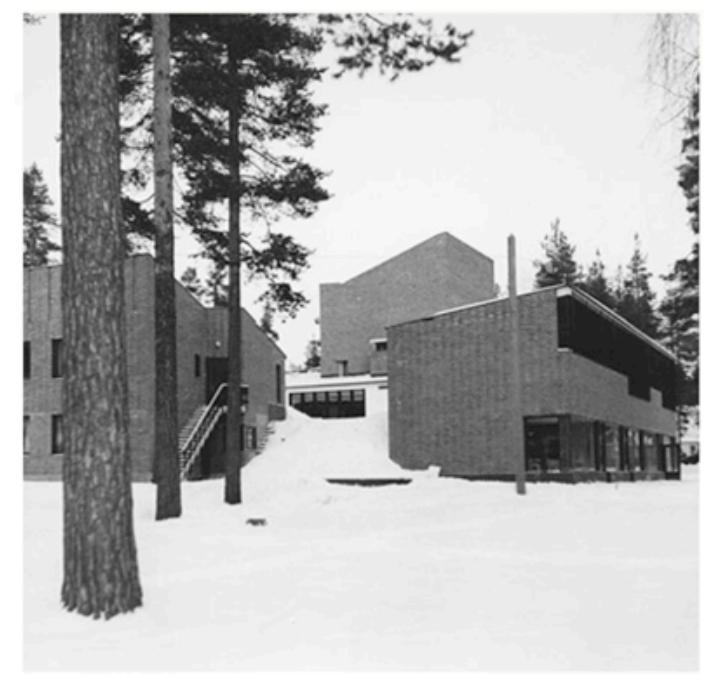

Figure 4: Alvar Aalto's Säynätsalo Town Hall. Exterior view. (Moser, L., Alvar Aalto Museum, n.d.). ventilation strategies could reduce cooling loads in the summer as well. The internal courtyard could also be used as the exterior space in properties lacking backyards. In locations with traffic noise, the internal courtyard might allow to open the windows towards a more quite area. Newly constructed row houses could take advantage of this feature to optimize the energy consumption and increase natural lighting. In many cases the introduction of skylights increase 
the amount of light in the house, but it does not provide visuals to an exterior or access to an outdoor space. The retrofit of existing row houses could also make good use of the natural light in the house to improve the wellbeing of the dwellers using a design like the house located in Buenos Aires, Argentina shown in Figure 5. It could also take advantage of open concept living areas by organizing the house around the internal courtyard.

Although there are examples of inner courtyards explored architecturally in Toronto, there is no evidence that this design feature has been examined from a building science aspect. This study will try to offer new information to those ones that appreciate internal courtyards as a mean to improve the natural light. It will also try to find information to understand energy performance implications and to explore passive strategies for heating and cooling.

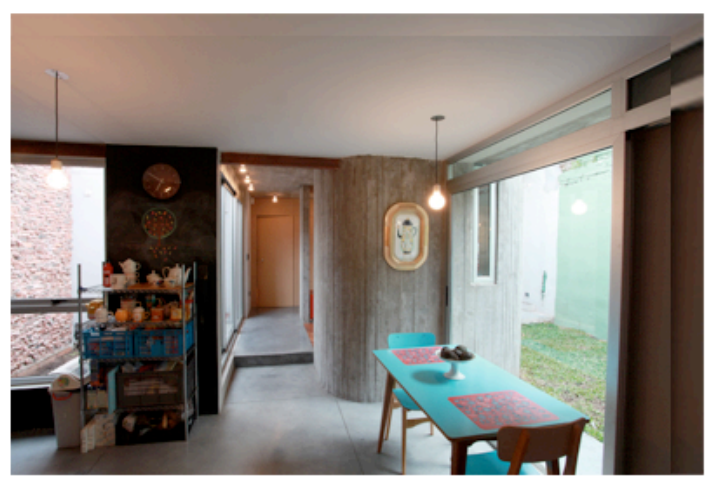

Figure 5: Interior courtyard in a house in Buenos Aires, Argentina. (Vaisman, 2009)

\section{Literature review}

\subsection{Courtyards and row houses in history}

Back in Neolithic settlements, the courtyard provided a protective configuration against outside dangers such as animals and human invasions. In urban areas the courtyard evolved into an efficient configuration to control sunlight (Özkan, 2005). Atillio Petruccioli (2006) analyzes the evolution of courtyards starting as an enclosing wall that evolves with the addition of cells around that space. $\mathrm{He}$ explains that the closed courtyard "is thus a product of cultural polygenesis dating from the Bronze Age, and it has endured in the Mediterranean basin in a 
form of the classical Roman atrium and Greek pasta house" (2006 P. 4). In Europe the row house archetype appears as a transformation of the domus, an archetype that does have a front, usually of shorter length than the sides and that is directly accessible from the street (Figure 6) (Ibid.).
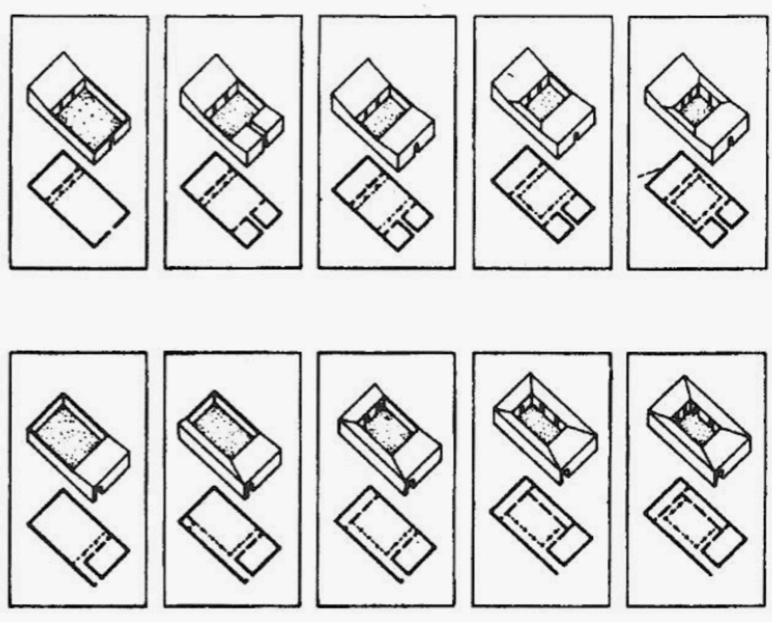

Figure 6: Typological process of a courtyard house (Petroccioli, 2006)
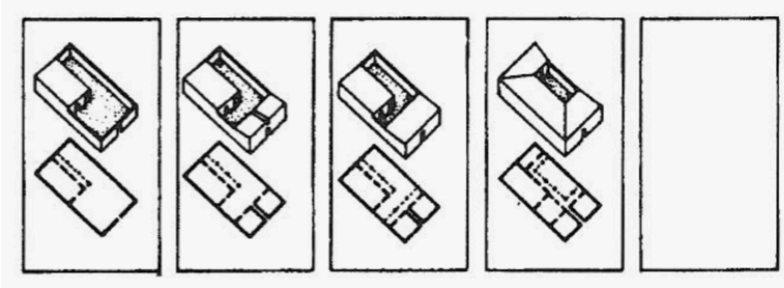

The domestic cell, as the starting configuration, evolves according to the culture. Back in the Roman times, row houses were designed linearly off a central axis, entering through a central vestibule into an internal courtyard, allowing light and fresh air inside the two-story building. Within the Middle Ages cities fortifications, two to five stories row houses were built as a result to the limited availability of land. The internal courtyard was also used as a service separator (Figure 7) (Friedman, 2012) and as the space between the public and the private domain. It can also be considered a cultural typology. In Islamic cultures, for example, the internal courtyard defined areas for gender separation, used 
exclusively by members of the family as an extension of the living rooms (Figure 8) (Özkan, 2005). Within hot arid climates, the internal courtyard configuration also offered urban density within low-rise buildings.

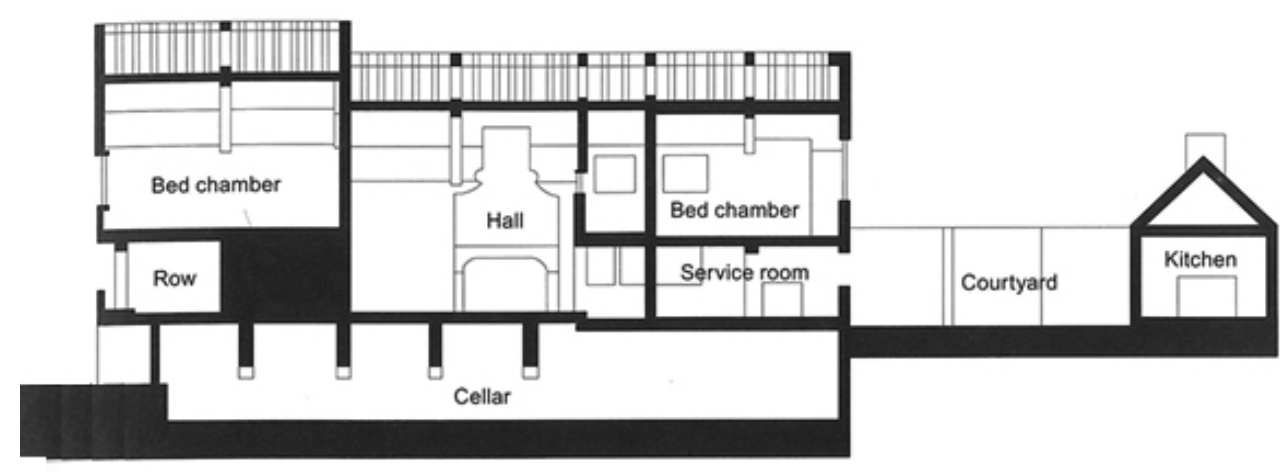

Section

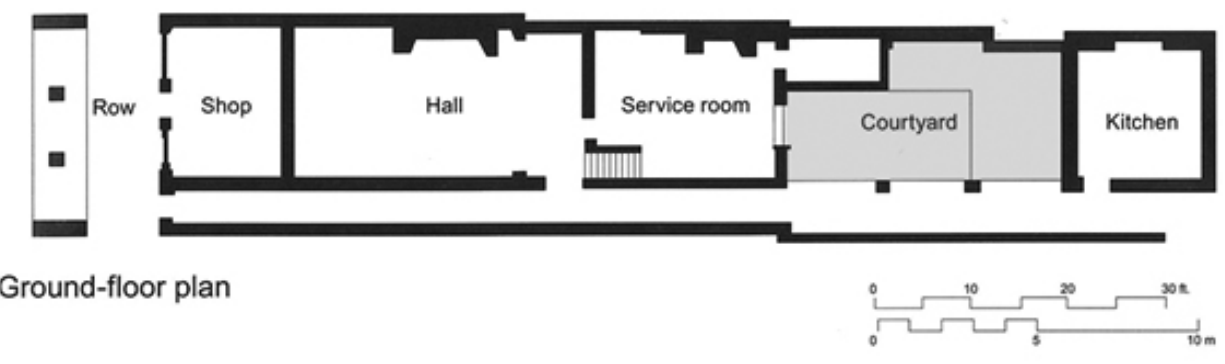

Figure 7: Middle age row house in Chester, UK. (Friedman, 2012)

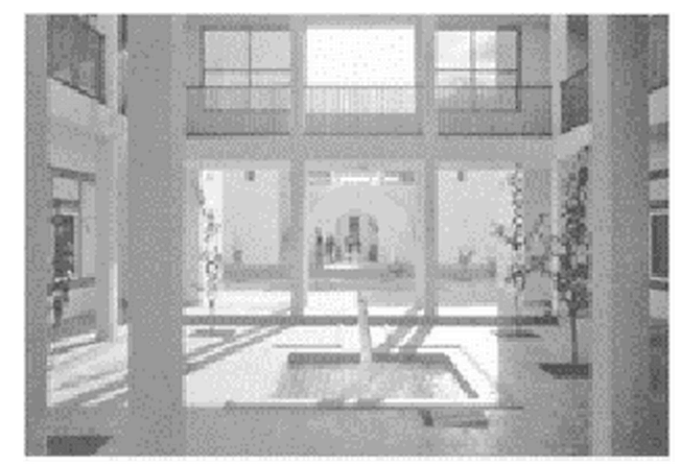

Figure 8: Residence Andalous in Sousse, Tunisia. Serge Sautelli (Özkan, 2005) 


\subsection{Courtyards as a protective configuration in cold climates}

In cold climates the effect of wind is usually a major concern and courtyards between houses could be used as a protection. Jorma Mänty, 1988, explains that vernacular urban courtyards have the ability to create pockets of solar gains and balance the harshness of the cold winter climates. Considering a larger scale, in communities in northern China buildings require internal courtyard as a health measure to protect the occupants from strong cold winds while maximizing the solar exposure. For example, in the city of Harbin, China, the introduction of the

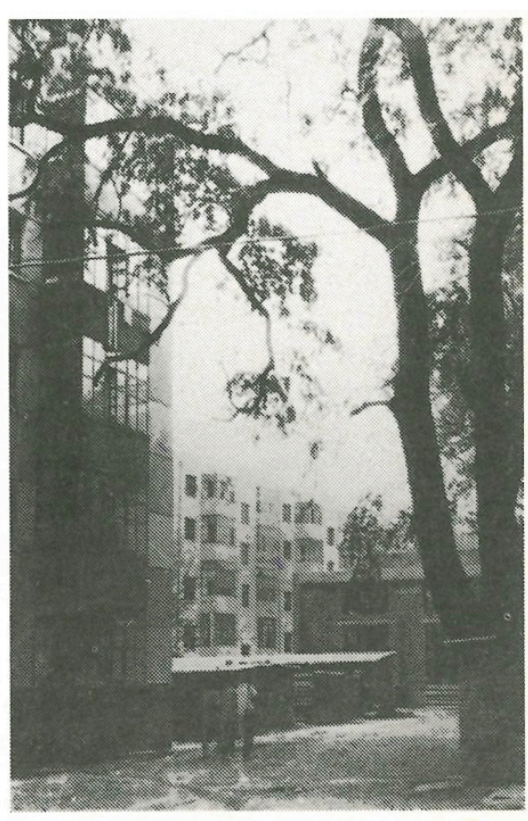

Figure 9: Internal courtyard and glazed balconies buildings in Harbin, China. (Liu, 1988) sun light in the neighborhood design has been a standard for many years, requiring no less than one hour of sunshine into south oriented first floor rooms on the winter solstice day. Plan developments in the 1950's maintained an interior open space design for five-stories buildings, where sun pockets are formed in the corner of two buildings while wind is buffered out (Figure 9) (Liu, 1988). An internal courtyard also generates a microclimate with increased average temperatures and it also shelter the dwellings from winds reducing the heat loss of the buildings surrounding it (Raydan et al, 2003).

The courtyard has also a long tradition in Scandinavia. It was used to organize a group of buildings to constitute a farm (Figure 10), as small buildings surrounding an open space with their small windows facing inwards (Ibid.). It is also used to extend the "outdoor season", with spaces to accommodate outdoor activities both for children and adults. The courtyard has a long history 
on urbanization used also as a physical setting for outdoors activities and socialization with examples where the courtyard becomes more important than the street (Ibid.) (Figure 11). In urban design, the courtyard can be considered as a "non-built part of the space between buildings". It was widely adopted in continental Europe and Scandinavia as an architectural requirements for light, air and contact with nature (Culjat et al, 1988). These spaces are achieved by a micro-climatic planning: protection from the wind, optimization of the orientation and the use of materials to absorb heat (Figure 12).

In some locations in Norway people are able to stay outside without feeling uncomfortable only between 64 to 133 days a year because of the low temperatures, but an internal courtyard can extend the outdoor season up to 42 more days (Ibid.). This urban design also uses the courtyard as a space for social interaction. While a row house with an internal courtyard has a lower scale, it offers possibilities for socialization as well.

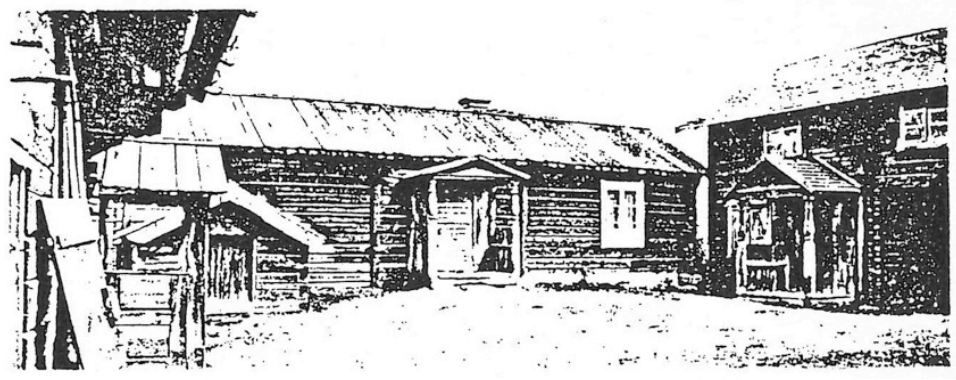

Figure 10: Farm in Dalarna, Norway. 1926.

(Cujlat et al, 1988). 


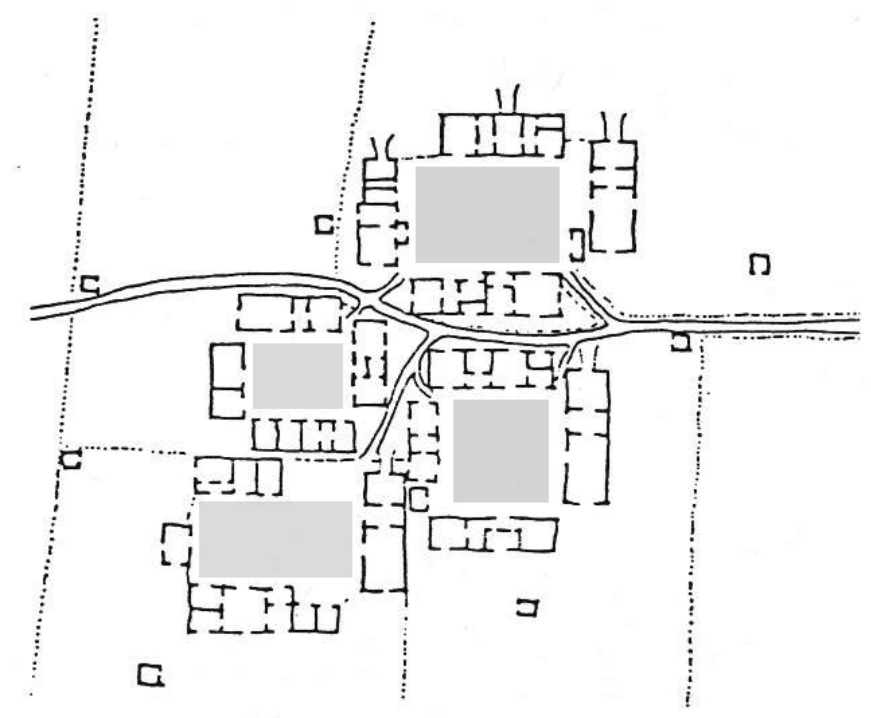

Figure 11: Østgård, Norway. Farm and Village. (Culjat et al, 1988).

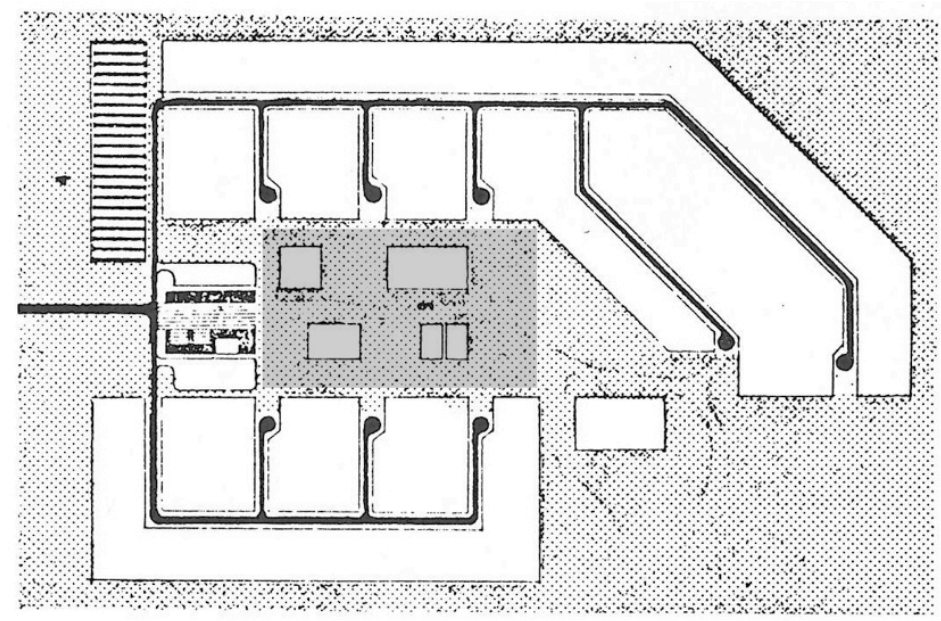

Figure 12: The "lung" pattern used in Finnish neigbourhood planning in the 1960's. Source: Olli Kivinen, HÄMEENLINNA GENERAL PLAN, 1957. (Mänty, 1998)

\subsection{Internal courtyards in contemporary houses}

Contemporary dwellings around the world offer alternative configurations of the courtyard according to the lot size, sun angle and code restrictions. Many of them use the internal courtyard as a design feature to enhance the interior space, combined with usable outdoor areas and landscaping. The internal courtyard offers new perspectives from the interior defining public and private 
areas as well (Figure 13). In some cases they are used to separate the entrance from the family zone, or the dining area from the rooming area (Figure 14) (Pfeifer et al, 2008). It can also be used as the only exterior space in locations where urban layouts require party walls for privacy.
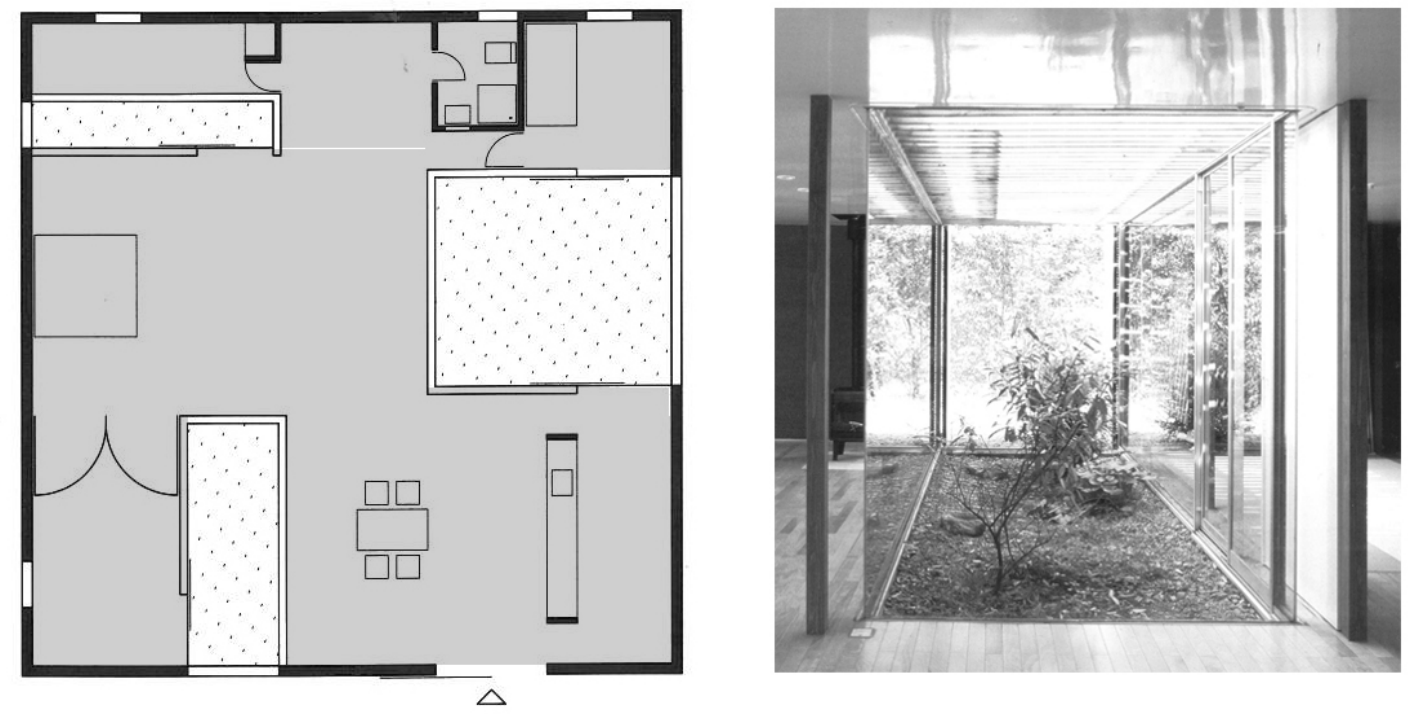

Figure 13: Courtyards used to separate the kitchen from the living area and the room. Weekend house. Tokyo, 1998. Ryue Nishizawa. (Pfeifer \& Brauneck, 2008)

For example, the "Machiya" house in Daita, Japan, shows almost no exposure to the public sphere using the internal courtyard as it main outdoor space (Figure 15). The need for privacy can also be found in a contemporary example from Brazil, where the courtyard is used as a private exterior space for a house within a narrow $3.7 \mathrm{~m}\left(12^{\prime}\right)$ wide lot. Located in the city of Porto Alegre, this house has an asymmetrical design complexity with a front garden and an internal courtyard to control light and ventilation. It has been designed to minimize the use of air conditioning (Friedman, 2010) (Figure 16). The internal courtyards are becoming a feature for high performance houses as well, like the 
house recently finished, designed by the architecture firm Snøhetta. The Zero Emission Buildings Multi-Comfort House is the result of a cooperation between the architecture firm Snøhetta, Scandinavia's largest independent research body SINTEF, ZEB partner Brødrene Dahl, and Optimera (Snøhetta, 2014) (Figure 17 and Figure 18).
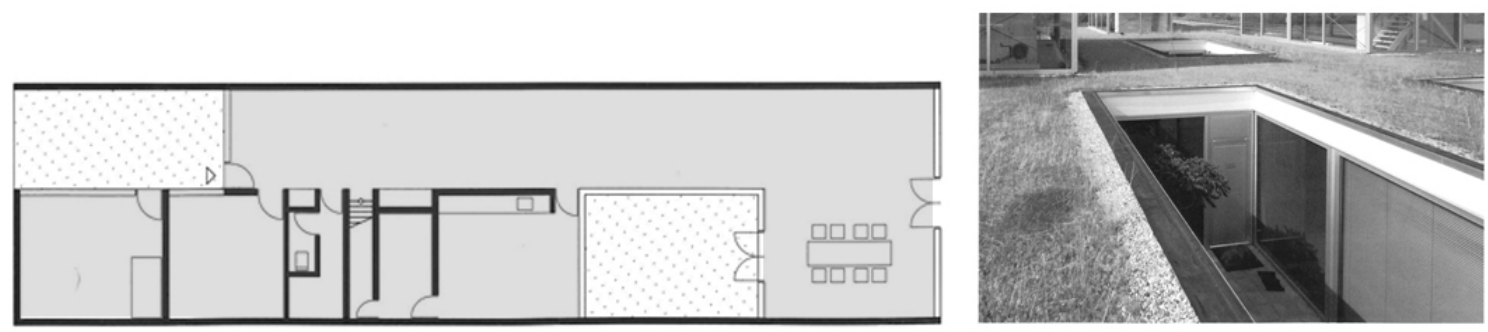

Figure 14: The internal courtyard is used to separate the kitchen from the dining room. Group of houses "Kleine Rieteiland". Amsterdam, 2004. Bosch Architects. (Pfeifer \& Brauneck, 2008)
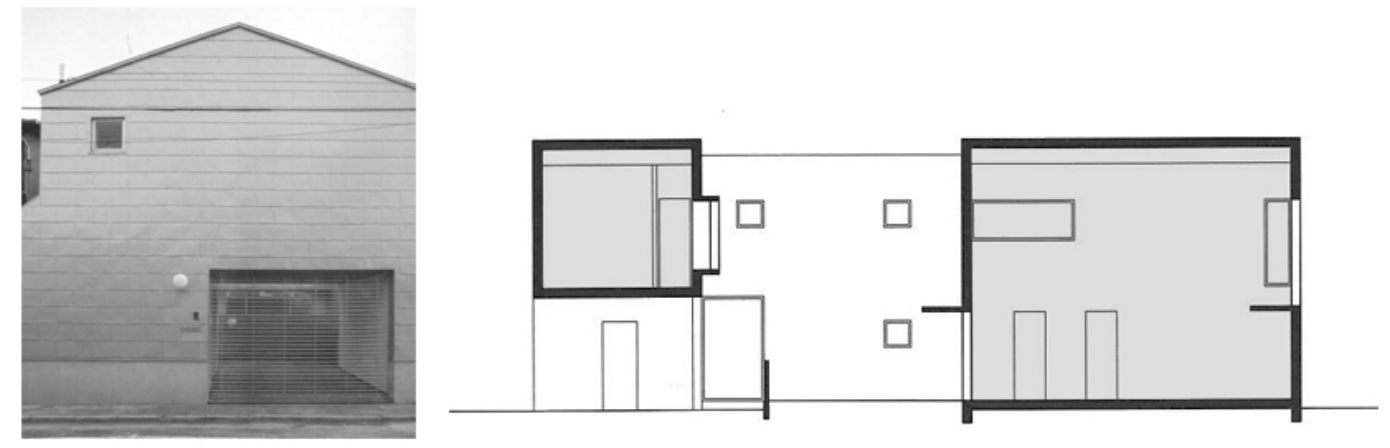

Figure 15: No exposure to the street. The courtyard is the main connection with the exterior. "Machiya" house. Daita, Japan. Kazunari Sakamoto. (Pfeifer\& Brauneck, 2008) 

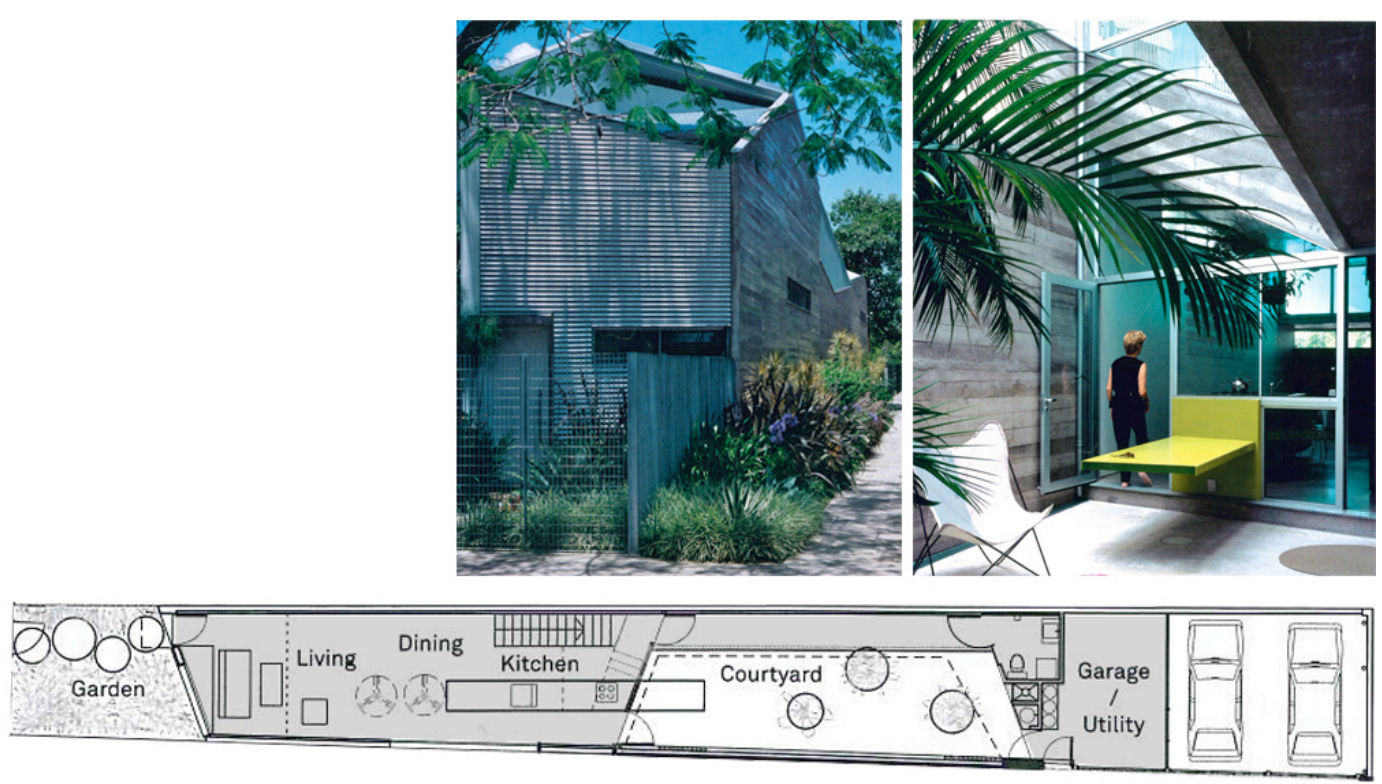

Figure 16: Slice House, Porto Alegre, Brazil. By Procter-Rihl Architects. 2005. (Friedman, 2010)

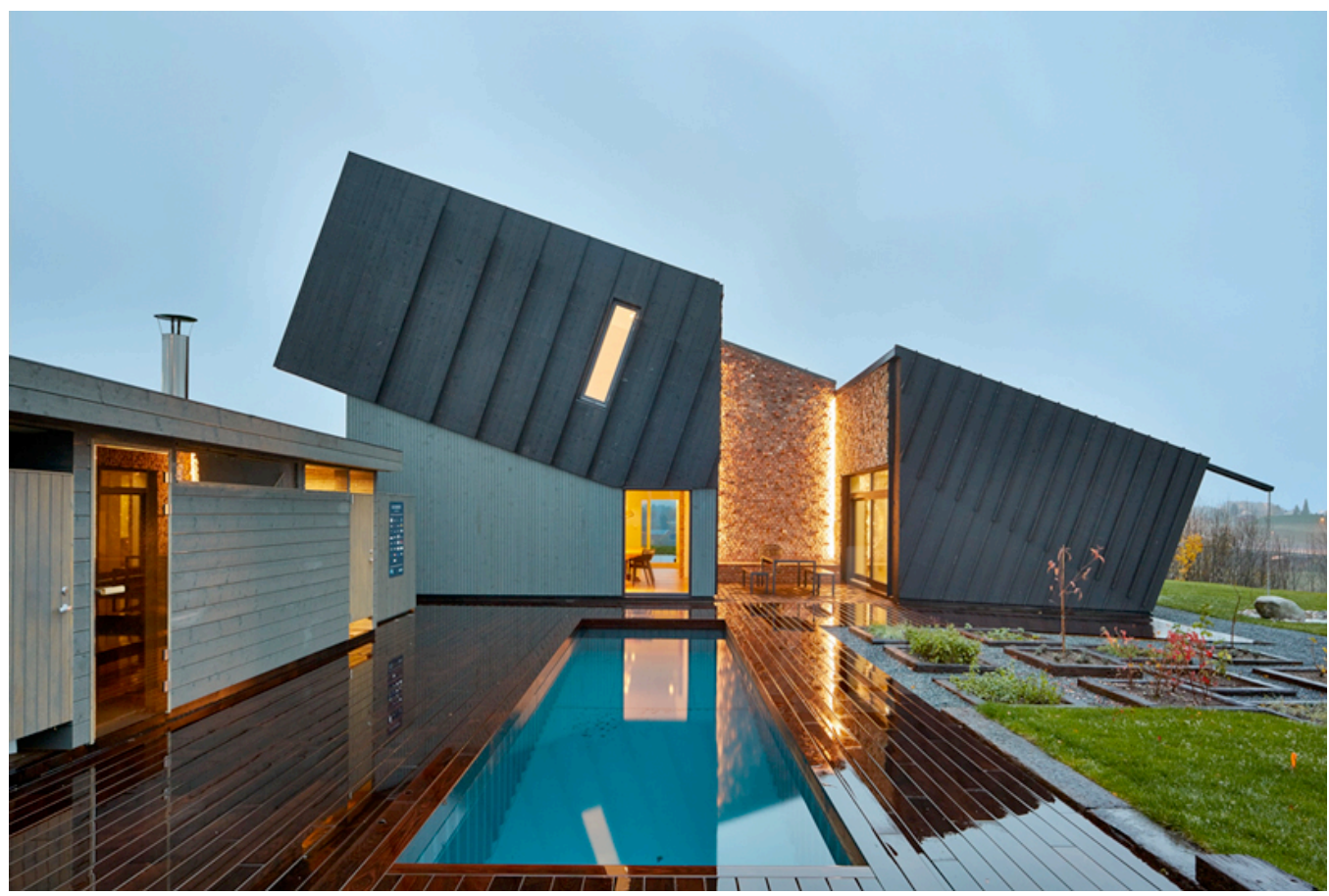

Figure 17: House with and internal courtyard in Norway . (Snøhetta, 2014 


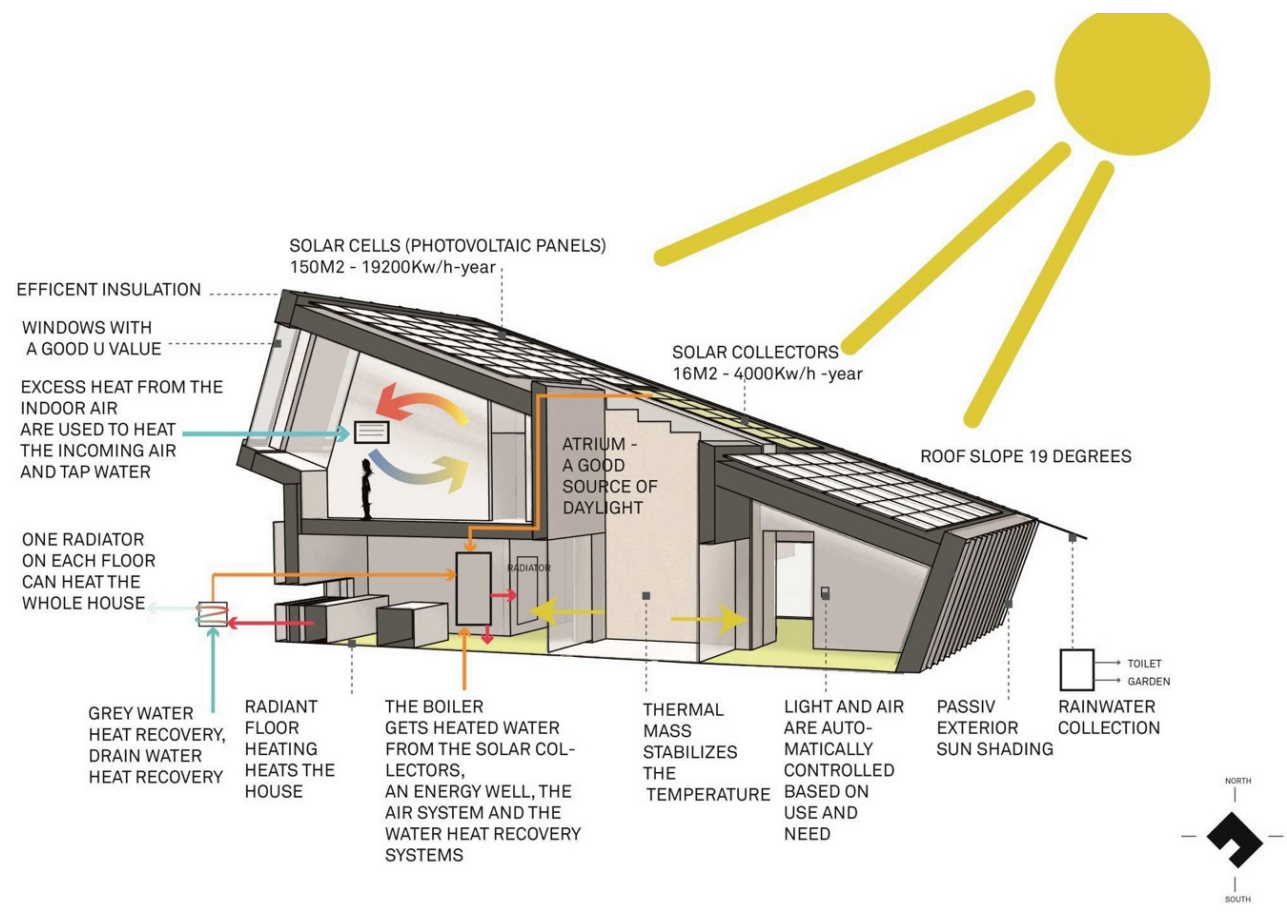

Figure 18: Mechanical scheme of a house with a courtyard in Norway . (Snøhetta, 2014).

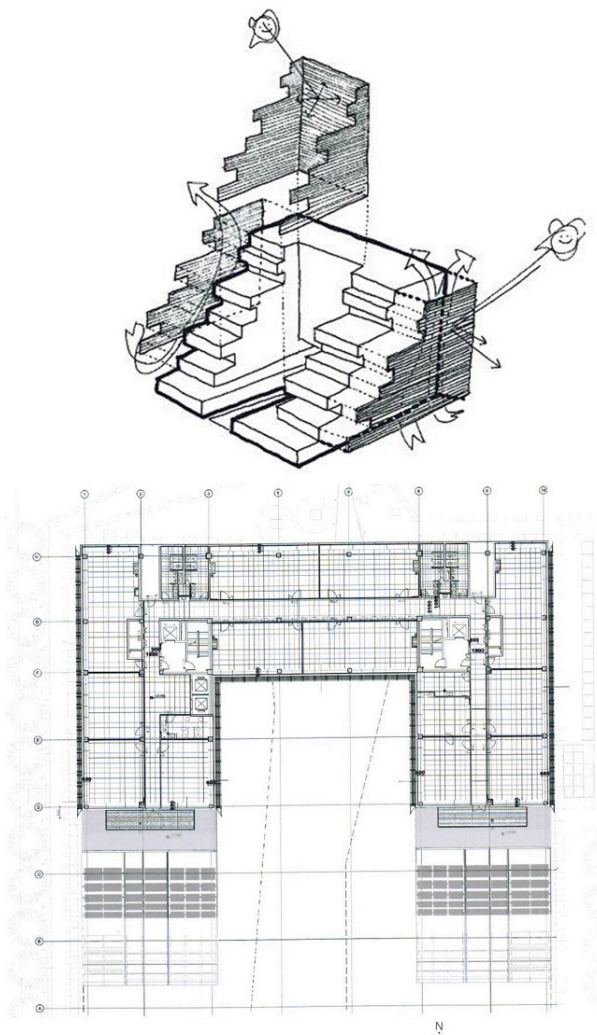

Figure 19: Sino-Italian Ecological and Energy Efficient Building. Beijing, China. (Guzowsky, 2010) 
Mario Cucinella Architects designed the Sino-Italian Ecological and Energy Efficient Building located in Tsinghua University, Beijing, China, a freestanding building that choses a U-shaped massing to contribute to the ecological design and the human experience. Cucinella considers that "beauty is always related to climate and solar exposure, challenged to experiment beyond energy performance to consider aesthetics and user experiences" (Guzowski, 2010).

The iterative process used in this project decided that the massing would lead to a shape that maximizes solar gains in winter and minimize them in the summer (Figure 19). The U-shaped option with the courtyard facing to the south was the key feature to optimize the passive strategies for day lighting, natural ventilation and solar heat gains. In this building the equilibrium between performance and shape was reached, considering the sun and wind as critical ecological design elements for Beijing (Ibid.).

In Canada, designs using enclosed internal courtyards can be found in houses even though it is not a usual feature. New row houses with internal courtyards are currently designed and built in Montreal like the one by Architect Gervais Fortin, which includes an internal courtyard as an exterior space (Figure 20). This designers are using the internal courtyard in a housing scale, while offering access to exterior spaces. This solutions also provide a response to higher density policies, while maintining an accesible exterior space. 


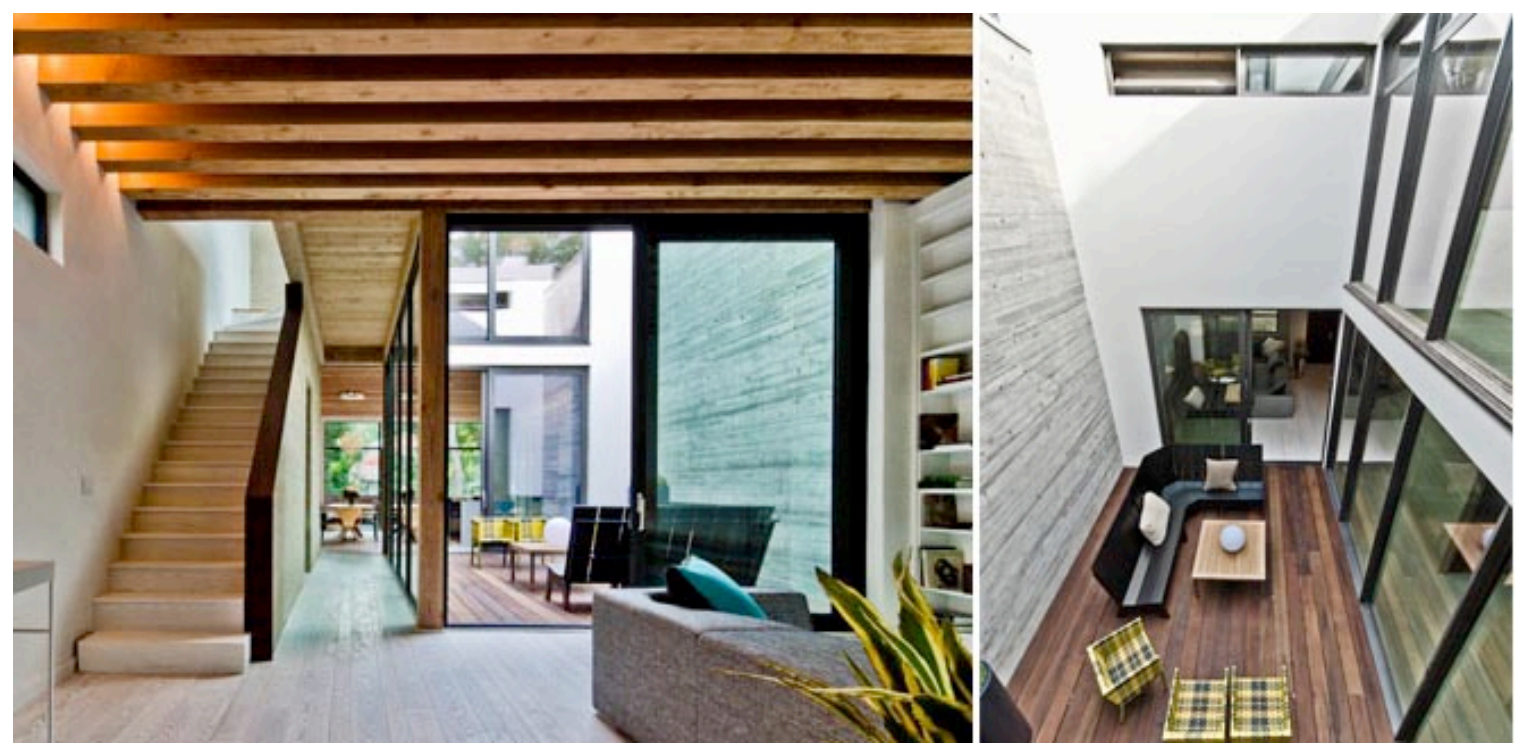

Figure 20: Internal courtyard in a row house in Montreal. 2014. (Fortin, 2014)

\subsection{The row house archetype in Toronto}

A row house can be defined as "one of three or more dwellings joined side by side (or occasionally side to back), such as a townhouse or garden home, but not having any other dwellings either above or below. Townhouses attached to a high-rise building are also classified as row houses." (CMHC, 2012). A row house can be also identified as "a single family house (...) each having individual identity both at front and to an identifiable ground space", as Jack Klein defines in the booklet from the Canadian Housing Design Council (Klein, 1971). Compared to single urban homes, row houses offer higher construction density (de la Riva, 1997) (Figure 21). The nature of the row house offers lower exposed surfaces, reducing the heat loss in the middle units. The International Energy Agency found that a townhouse can actually reduce up to $68 \%$ of energy compared to a detach house depending on the location (Friedman, 2012).

The row house typology was brought to North America by British migration, and by 1830's it had become a common archetype in Kingston, Toronto and English- 
speaking Montreal (Ward, 1999). The single family unit row houses can be found in Montreal dating as far as 1727 . Back then an ordinance was established to use masonry and stonewalls in the party walls to prevent the spread of fire between them. There are examples found in Quebec dating as far as 1801, with units designed from 5 to 10 meters wide (de la Riva, 1997).

In Toronto, located in Jarvis St, a row house from the early 1900's shows a shared side setback in the back of the house (Figure 24). This common design feature allows natural light and ventilation into the middle of the dwelling and can be found in designs from that time (Figure 23) with many of them still standing in Toronto (Figure 22). Currently, the increasing cost of the properties and the limited availability of land makes the row house a suitable option to own a house while improving the urban density and the energy efficiency. The 2011 Census of Canada counted 155,200 semi-detached and duplex buildings and 179,100 row housing units in the city of Toronto alone. The stock of semi-detached and row houses in Toronto accounts for the $7.8 \%$ and $9 \%$ respectively of the total dwelling units in the city. (CMHC, 2014).
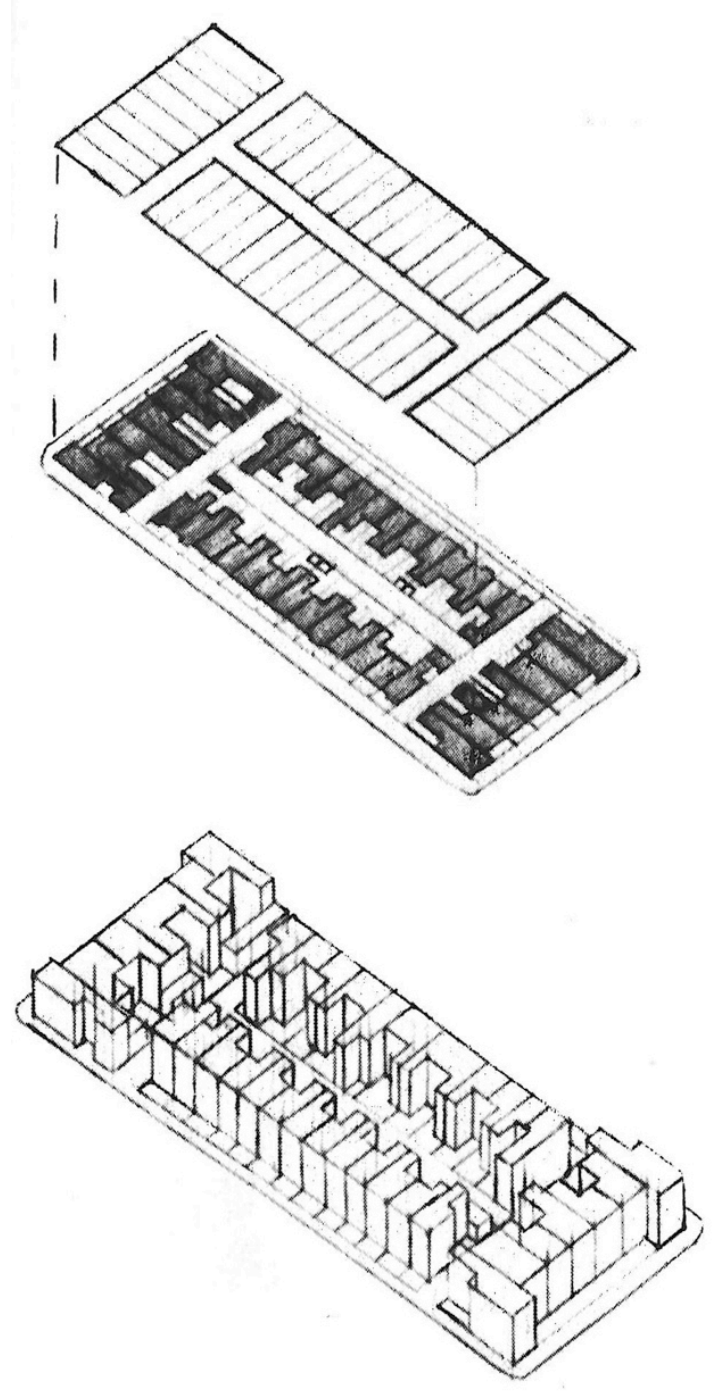

Figure 21: Row house buildings coverage averages $60 \%$ of the available land. (de la Riva, 1997) 


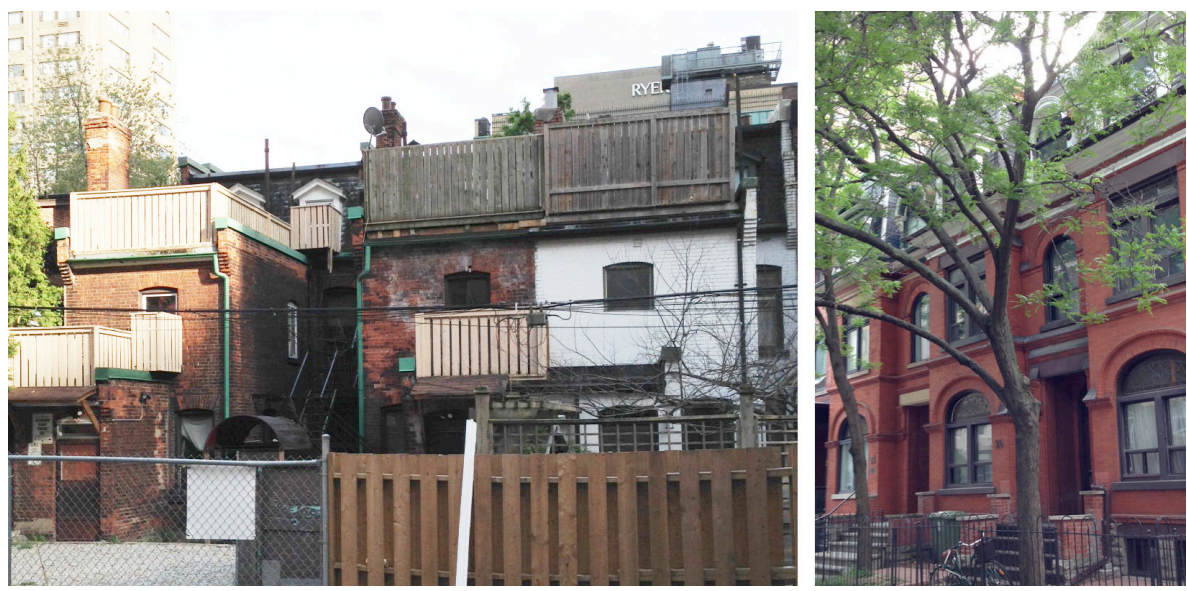

Figure 22: Row houses at 24 McGill St, Toronto. You can see the side setbacks on the rear of the house.

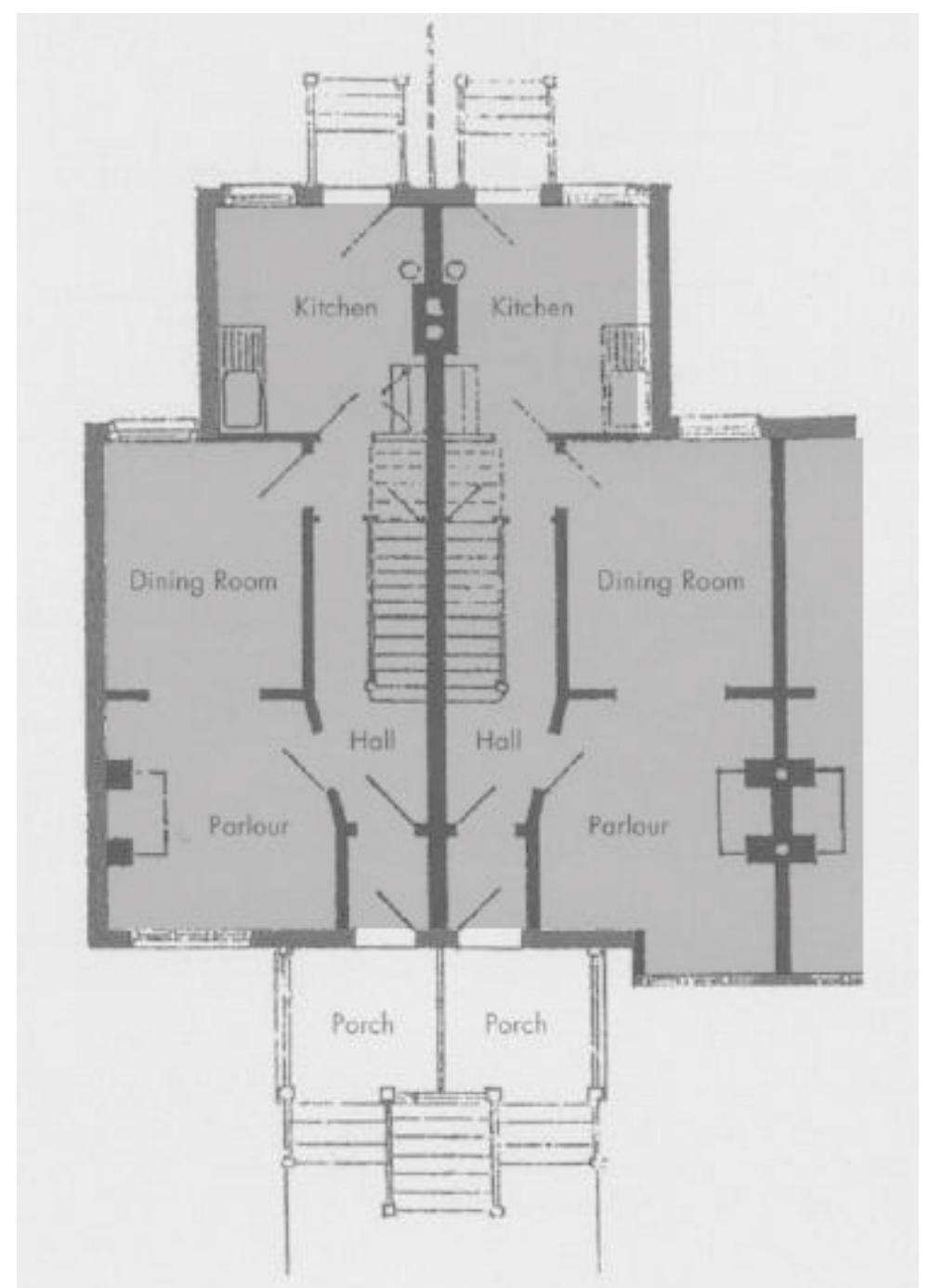

Figure 23: Row houses in Toronto located at 486 Shaw St. with $4.2 \mathrm{~m}$ wide lots. 


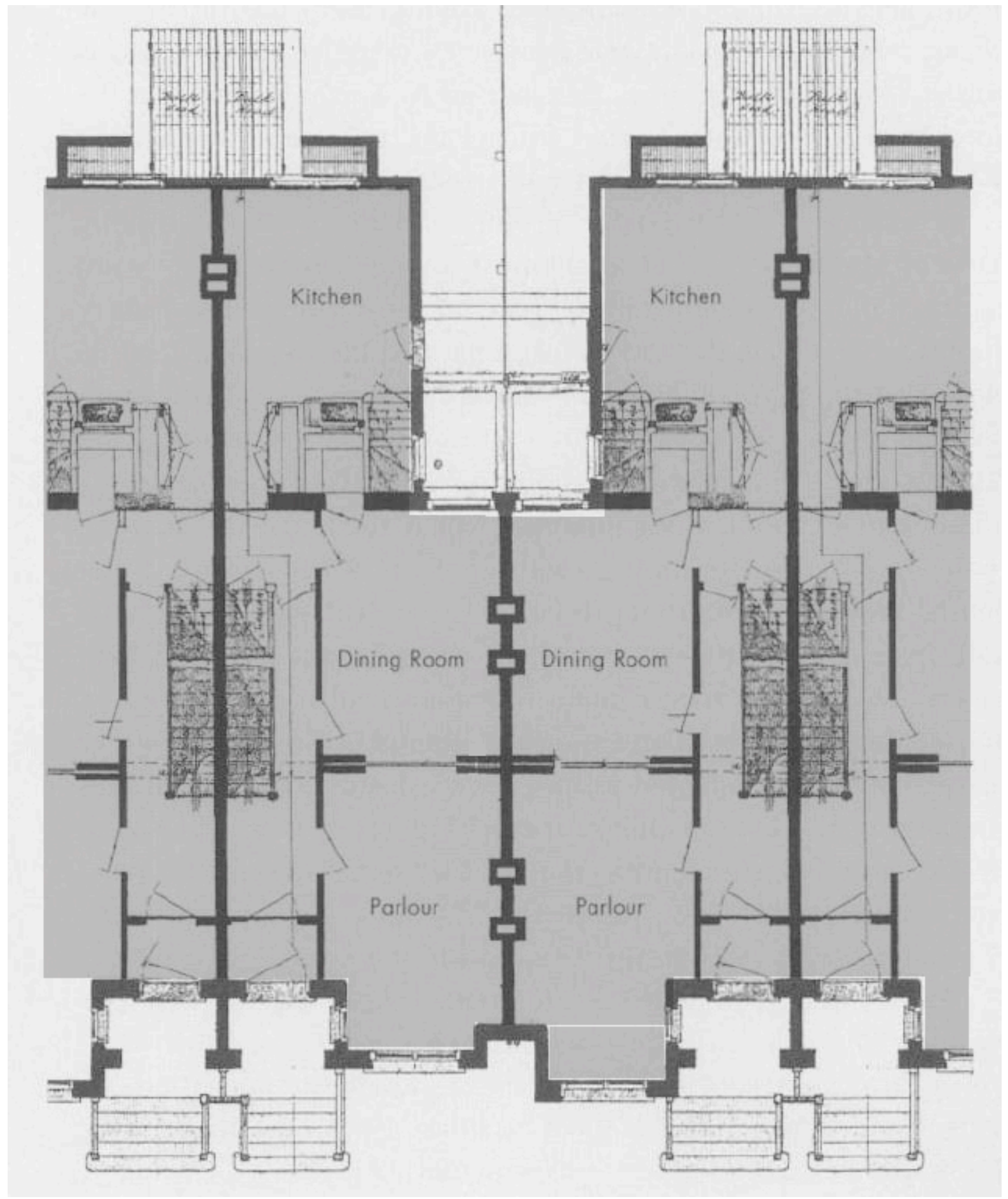

Figure 24: Row house plan from 1887 in Jarvis St., Toronto. (Ward, 1999) 
Toronto has examples from decades ago revealing how the zoning influenced the internal courtyards use in row houses. The lack of early development of internal courtyards might have a direct relationship with former bylaws. A zoning report about town housing, issued to the City of Toronto Planning Board in February of 1963, aimed to develop a flexible town house category without infringing the, then existing baylaw that prohibited the construction of one dwelling behind another. On page ten of that report it is mentioned that the requirements of side yards on any part of a building longer than $9.15 \mathrm{~m}\left(30^{\prime}\right)$ seemed to be an unnecessary restrictions "preventing the development of any interesting development effects, such as courtyards" (M.B.M. Lawson, Commissioner of Planning City of Toronto, 1963).

Currently, interior courtyards within row houses are not common in Toronto even though the Ontario Building Code (OBC) does not prevent them. An internal courtyard can be approved under the minimum requirements for party walls, terraces and fenestrations. These variables mandate dimensions and minimum requirements when designing row houses with internal courtyards, even though the $\mathrm{OBC}$ does not mention the courtyards explicitly. Subsection 3.2.3 of the $\mathrm{OBC}$ establishes the spatial separation and exposure for fire protection considering unprotected surface size and the distance beyond the property line. This subsection establishes the maximum opening size allowance and, as the openings of internal courtyards are unprotected surfaces, the size and distance to the next property line have to be considered on such variables (Ontario Building Code - 2006, 2010). These considerations do not show any limit towards designing an internal courtyard in a row house.

As mentioned before, the row house archetype has long history in the Toronto and it is still used widely, but the use of internal courtyards in that archetype is 
not a common practice. There are some outliers, like the 40R Laneway House designed by the architecture firm Superkül (Figure 25). The internal courtyard is used both to increase the natural light and as a transitional space to the roof terrace. The stairs to the terrace are located within the internal courtyard, simplifying the transition inside-outside with a regular siding door. The design

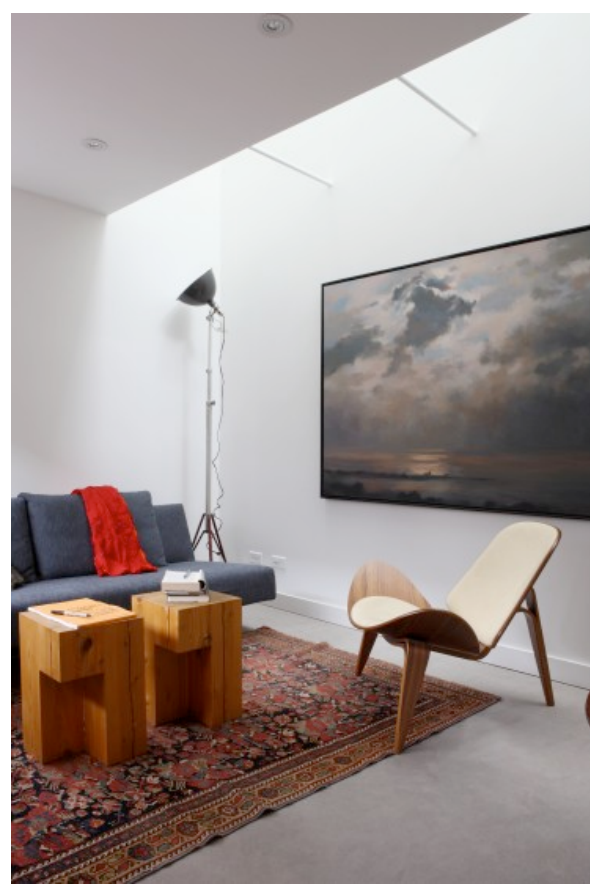
adds two long side skylights to illuminate the interior without taking full advantage of the courtyard as a light source. This house doesn't share party walls with other buildings but, even though it's not a row house per se, it does have a morphology similar to one. Another example in the City of Toronto is a retrofit of a row house located in the Junction neighbourhood, where an internal courtyard is added to a row house originally built in 1889 (Figure 26). This property accommodates a store in the ground

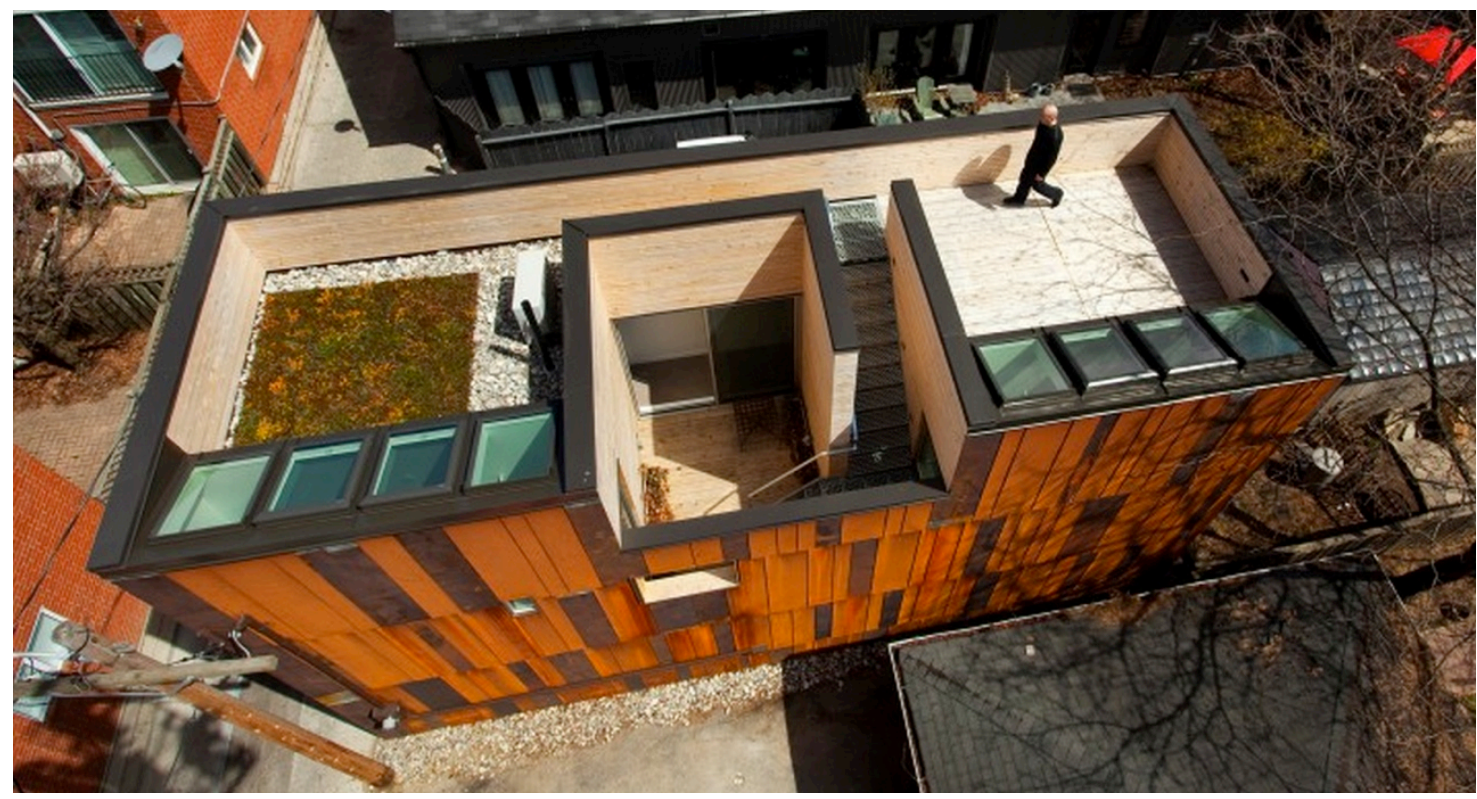

Figure 25: (a) Interior and (b) exterior. Laneway house. Superkül Studio. (Superkül, 2014) 
floor and a single-family unit in the second and third floors. The added courtyard brings light to the $3^{\text {rd }}$ floor through their glazed doors and to the $2^{\text {nd }}$ floor using a skylight located within the courtyard. This inclusion has to do with a programmatic reason. The owners decided to locate the living room, kitchen and dinning areas in the upper floor along the internal courtyard to maximize the light and to use it as an outdoor space resolving their lack of a backyard (Figure 26).
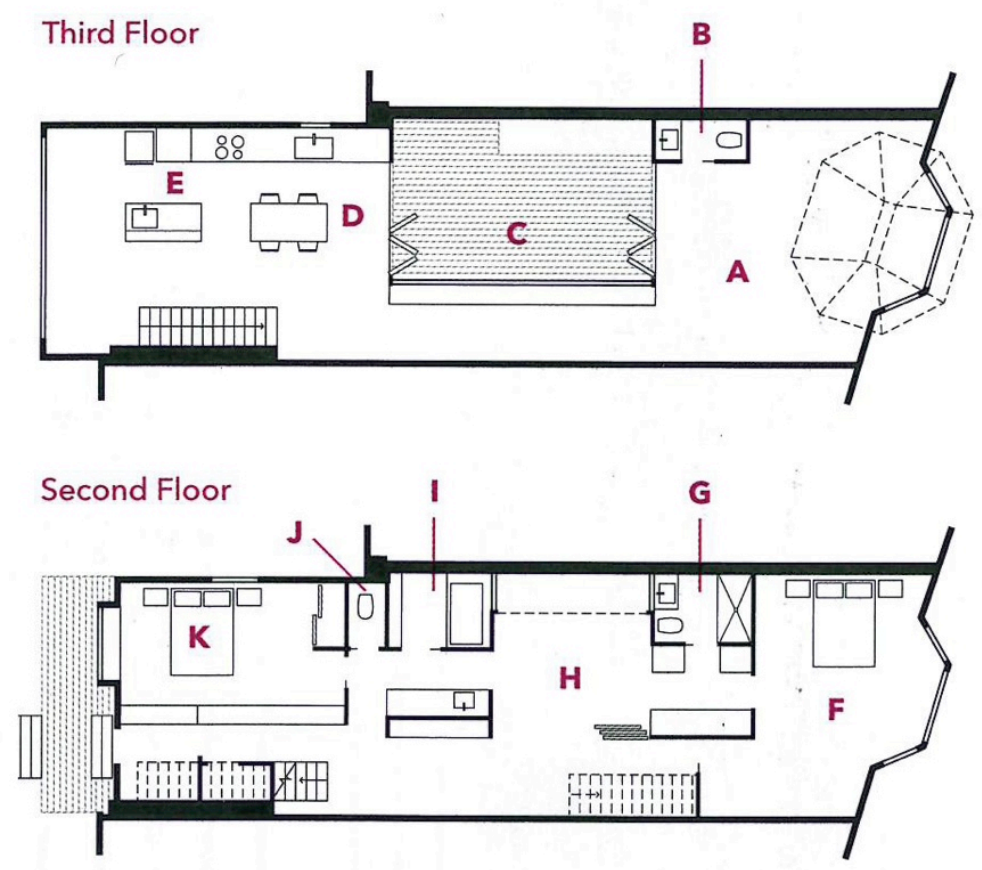

Figure 26: Row house with an internal courtyard located in Toronto. (Dwell, 2014)

The courtyard works as a source of natural light and as a separation between the kitchen and the living room. It is also an exterior expansion of the living room and kitchen when the large glazed doors are open. The internal courtyard has become their "backyard", as the owners comment when they are asked about how do they use it: "It is the a place where their kids play safely while we are cooking, and where we have nice dinners with friends in the warmer months." (G. Vaisman, personal communication, June 2014) (Figure 27). 

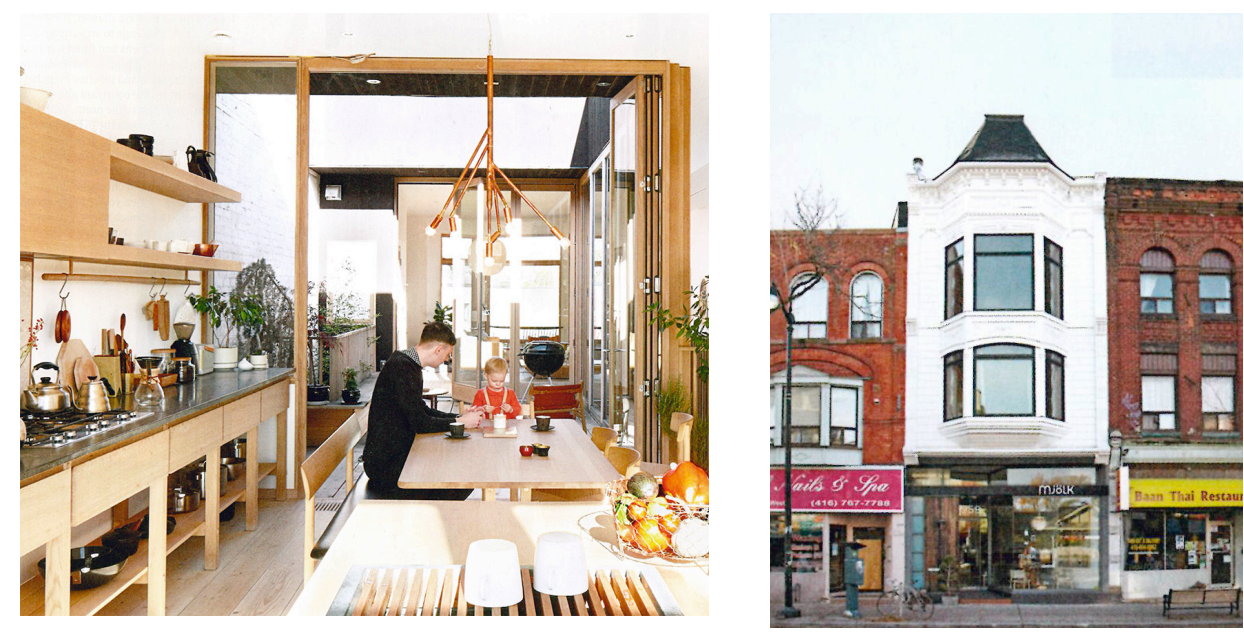

Figure 27: (a) (b) Row house with an internal courtyard located in Toronto (Shapton, 2014)

\subsection{Energy performance of row houses with internal courtyards}

Houses sharing a party wall take advantage of less exposed exterior walls and therefore get reduced energy consumption due to heat loss. The inclusion of an internal courtyard challenges the energy performance of the row house, as the exposed surface is now increased. On the other hand, the added exposure to the sun increases the heat gains that might offset that loss.

Rectangular shapes have better floor area to perimeter ratio than volumes with odd shapes or shapes with many corners (Figure 28). They minimize the floor area to perimeter ratio having a comparable lower heat loss ratio than morphologies with multiple shapes (Friedman, 2012).

Rectangular shapes perform better regarding the energy losses. In the case of the row house with an internal courtyard, the floor area to perimeter ratio becomes higher than a regular row house. It has more exposed surfaces increasing the heat loss during the winters. But in a context where the thermal insulation of the envelope is high, the solar gains might become more significant than the heat losses. 


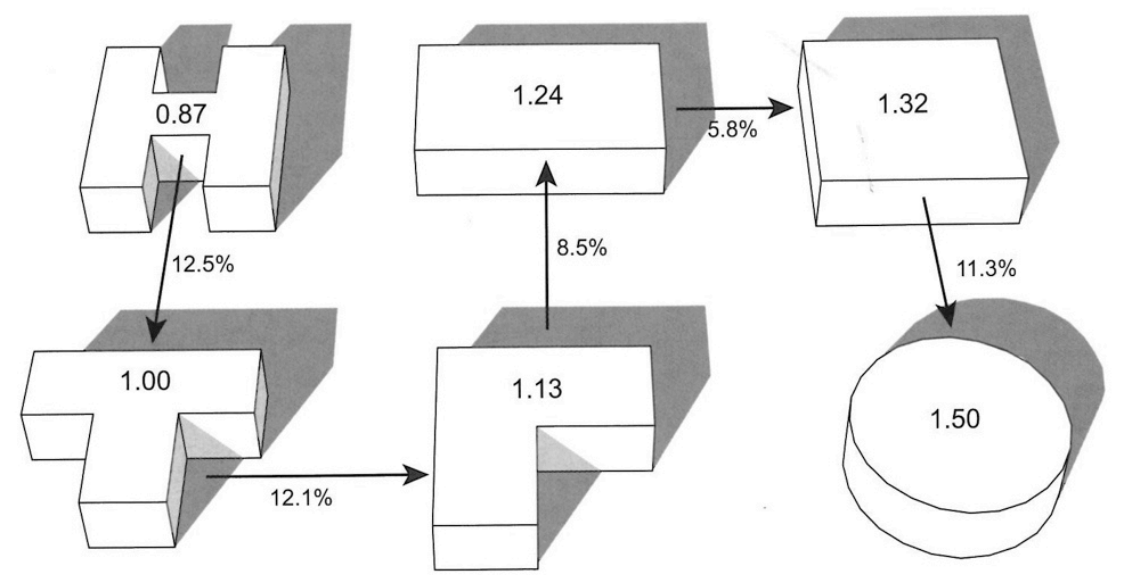

Figure 28: Floor to surface ratios: the higher the ratio the lower the energy consumption. (Friedman, 2012)

\subsection{Footprint and height of the courtyard}

Daylight and sun energy harvesting will be directly related to the orientation and to the amount of fenestrations where the sun intersects the building enclosure. In the East-West orientation, a regular row house does not have the larger surface facing the sun as it is the wall directly shared with the subsequent dwellings (Figure 29).
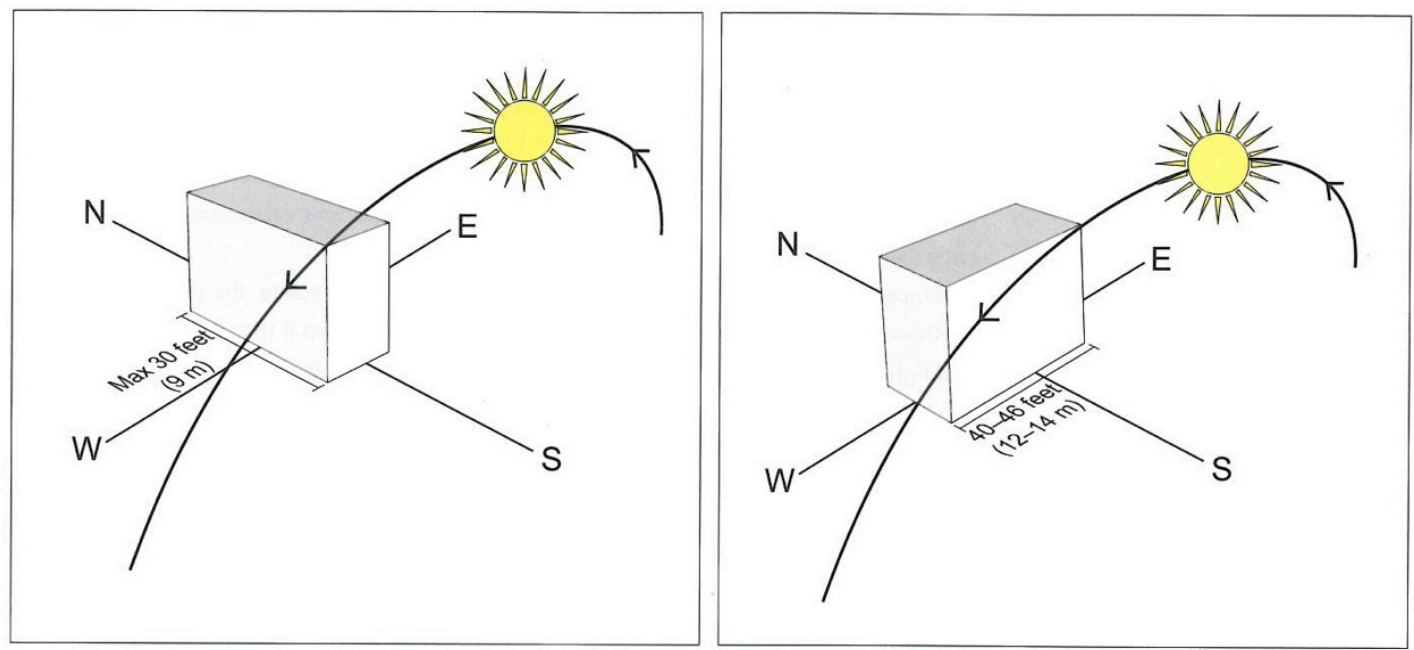

Figure 29: Daylight entering the house according to the orientation. (Friedman, 2012) 
As the sunlight is able to enter from the front and the back, the length of the row house will have an impact on the incoming sunlight according to it orientation. According to Friedman, 2012, it is recommended a 9m (30ft) maximum length for houses oriented North-South, and between 12 and $14 \mathrm{~m}$ (40-46ft) for East-West oriented ones for the natural light to able to enter. To improve the natural light in the core of the house, additional skylights or light wells are usually considered.

In colder climates, the sun is desirable in the winter, and the internal courtyard windows could be used to satisfy that need. A window in the courtyard could also provide easy access to shading controls in the summer, when the sun is less desirable (Figure 30). The proportions between height and width are crucial when designing a sun collecting or a sun-protecting courtyard. As comfort conditions are a function of air speed, radiant heating and temperature, the protection from the wind would also mean an increase in comfort conditions (Raydan et al., 2003). A height over width ratio averaging 0.6 defines the concentrating sun characteristic of the Scandinavian courtyard, compared to an average height to width ratio of 1.3 for a hot climate.
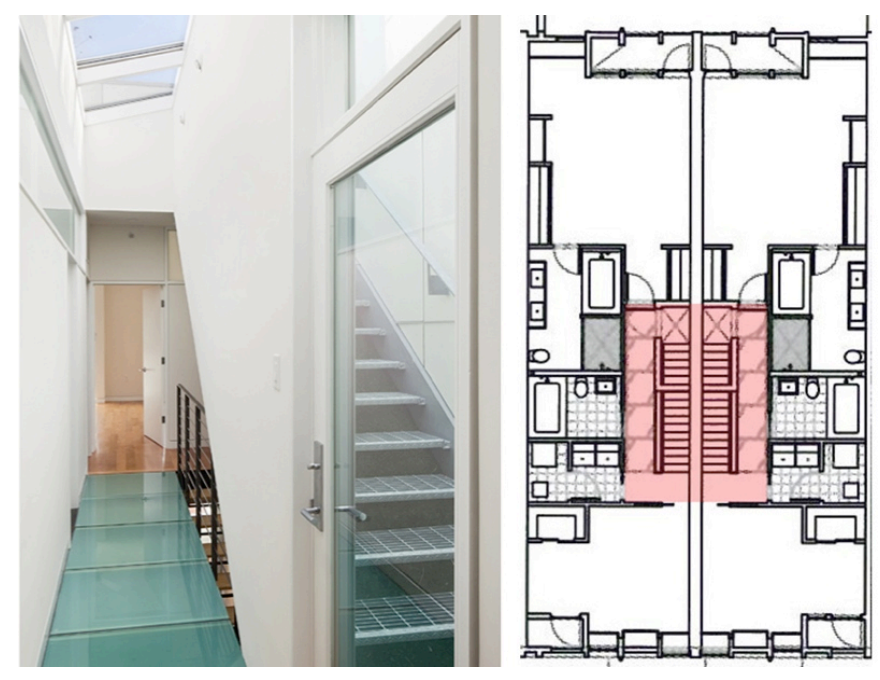

Figure 30: Side glazed windows and skylights. Thin flats. Philadelphia, Pennsylvania. Onion Flats. (Onion Flats, 2014) 

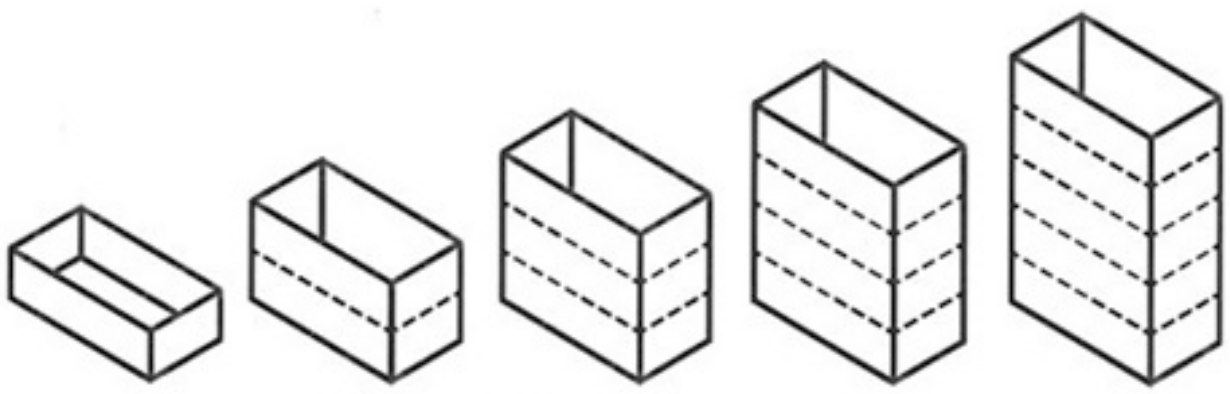

Figure 31: Higher amount of sun lit configuration. With a decrease of $6.6 \%$ of sunlit for each floor added. (Muhaisen, 2006)

To take advantage of the sun radiation and light, the sunlit surface of an internal courtyard has to be maximized. On every $3 \mathrm{~m}$ high story added in a rectangular courtyard of $30 \mathrm{~m}^{2}$ the exposed area to the sun decreases of $6.6 \%$ (Muhaisen, 2006). A shorter [shallower] height will increase the surface percentage reached by the sun (Figure 31). The best performance obtained in the summer and winter for colder climates is to be a one-story internal courtyard. (Ibid.). In a study about courtyard proportions on solar heat gain and energy requirements, it was found that for Rome $\left(41^{\circ} \mathrm{N}\right)$, a city located in a similar latitude than Toronto $\left(43^{\circ} \mathrm{N}\right)$, deeper courtyards forms obtained better performance on reducing the cooling load in summer and heating load in winter (Muhaisen \& Gadi, 2006). If the sunlit area of an internal courtyard is considered, in Rome, a rectangular courtyard has $11 \%$ of the sunlit area from East-West axis orientation, compared to $16 \%$ in the North-South oriented one (Figure 32). To maximize the potential sun exposure of the internal courtyard walls, it is recommended to orient the rectangular courtyard somewhere around the northsouth axis (Muhaisen, 2006). It is important to note that even though Toronto and Rome are in a similar latitude, they do have a different climate pattern. 

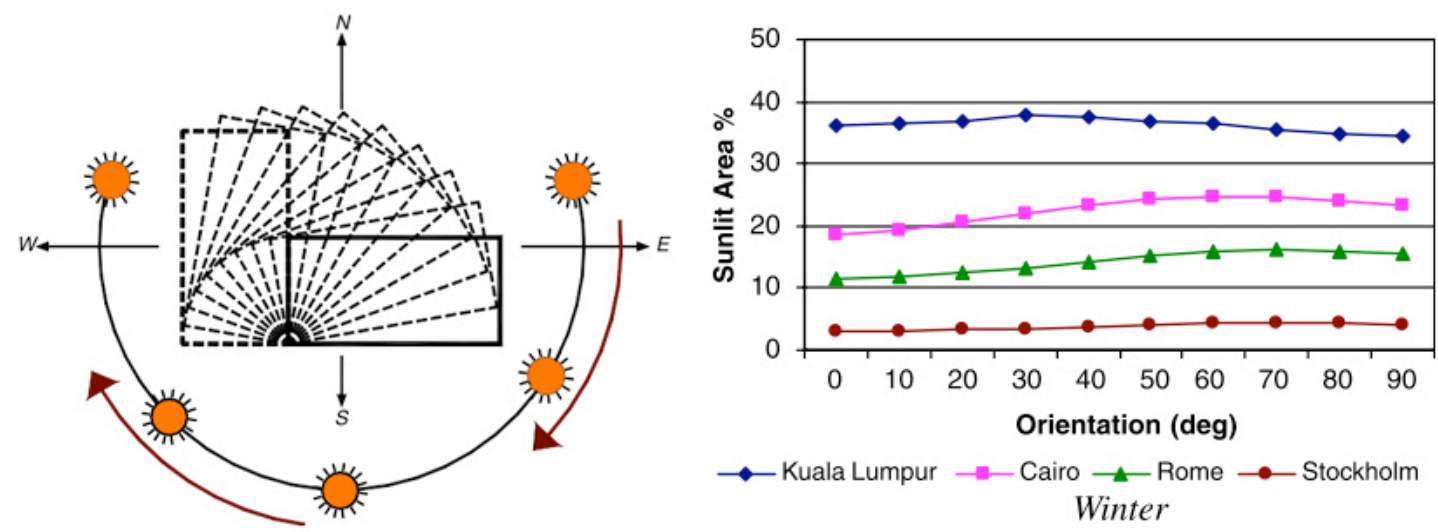

Figure 32: Effect of changing the orientation on the percentage of surface lit. (Muhaisen, 2006)

In high sun altitude cities like Toronto, the solar radiation received in summer is greater in horizontal surfaces than in vertical ones. This makes the floor of a courtyard the most important element when considering heat gains in summer (Muhaisen \& Gadi, 2006). The floor surface of an internal courtyard could then have proper perennial landscaping to absorb solar radiation in the summer and allow for solar gains in the winter.

The window assemblies also have a direct impact on the energy performance of a building. The heat losses of the building are directly related to the size of the fenestrations, as the window components usually have lower thermal resistance than the wall assembly. The glazing component has also a direct impact on the energy performance and when the building with an internal courtyard has more stories, the heat loss increases as well (Aldawoud, 2008) (Figure 33). 


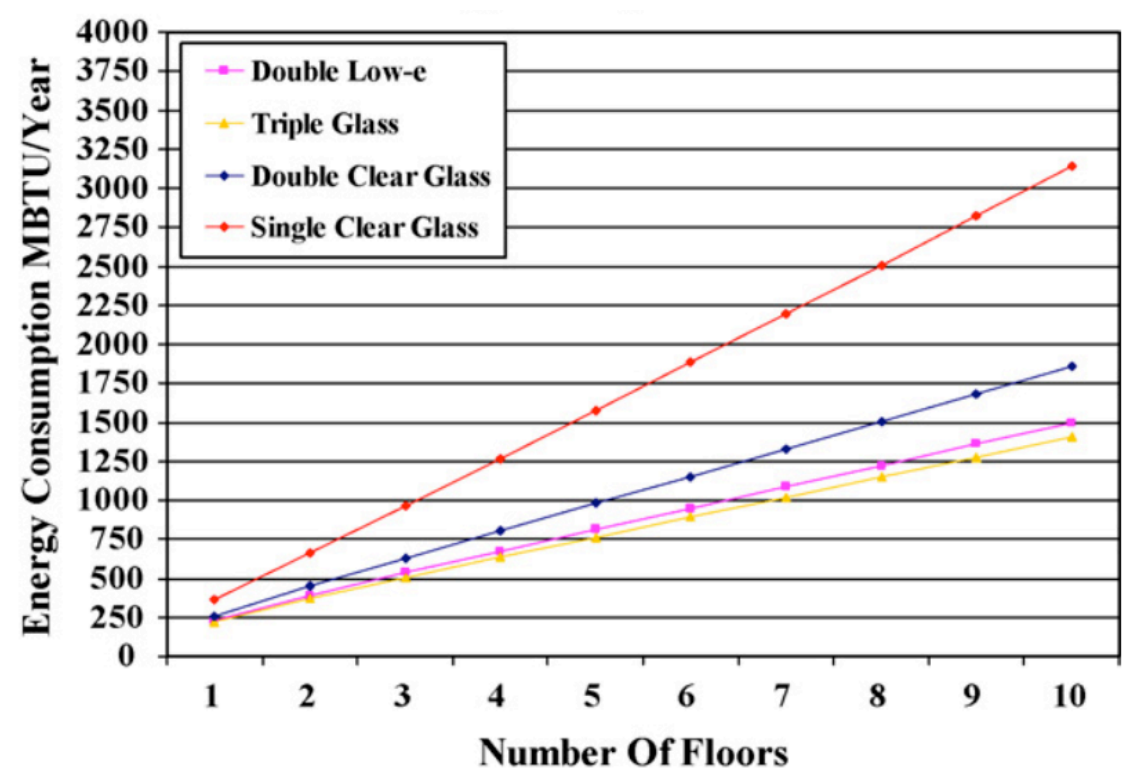

Figure 33: Courtyard Glazing Performance at $67 \%$ surface area in temperate climate. (Aldawoud, 2008)

Street noise might prevent the opening of the windows, mostly during the night hours when quite is needed. In an urban setting with noise and traffic, the courtyard could provide a quitter exterior (Culjat et al, 1988). Rooms that have walls facing courtyards can also benefit as it has been found that the internal courtyards reduce the variability of the noise levels experienced in the interior. The most significant parameter on reducing the noise level experienced is the height of the courtyard walls. Width and depth of the courtyard configuration had negligible variance (Oldham \& Mohsen, 1979).

Internal courtyards deliver better performance regarding noise reduction compared with other protected outdoor spaces, making them suitable to reduce the street noise. This is particularly important when passive ventilation strategies are planned, as to ventilate the space, opening windows are expected. Passive strategies are not only about providing operable windows and cross ventilation, but providing the ability to open them without losing comfort. 


\subsection{Hybrid system: Courtyard/atrium.}

Taleghani, Tenpierik and van den Dobbelsteen (2014) compared the energy performance of 2 row houses with internal courtyards with a reference model without one (Figure 34).

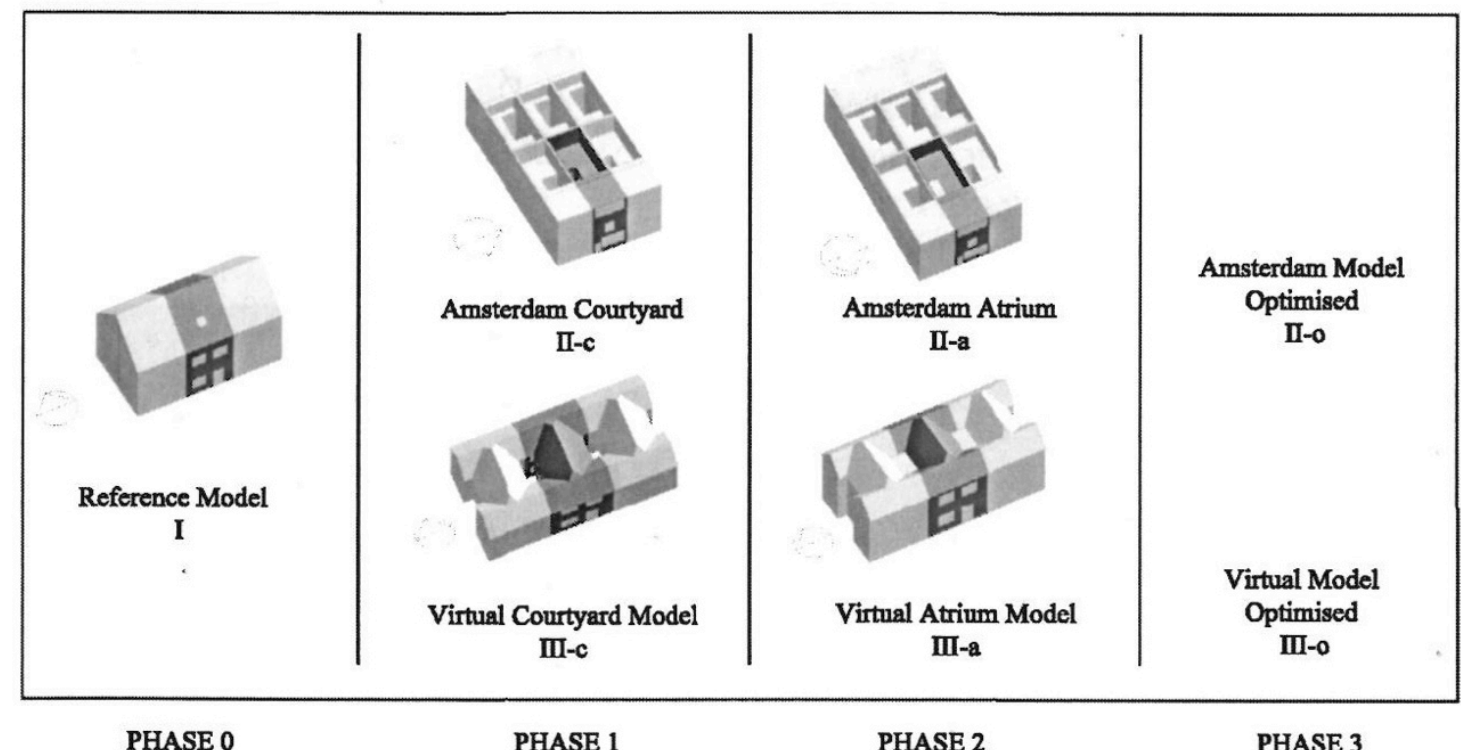

PHASE 0

PHASE 1

PHASE 2

PHASE 3

Figure 34: Models for the analysis of internal courtyards in the Netherlands. (Taleghani et al, 2013)

One of the row houses was modeled from an existing building and the second one was based on the reference model with the introduction of an internal courtyard. Their analysis covers an option where the internal courtyard is closed with glass and thus used as a buffer zone in the winter. Asking whether the use of transitional spaces can be a solution for climate change in temperate climates, their research looks at the internal courtyards benefits to reducing the interior comfort. They found that the optimal combination is to have an open internal courtyard that could be closed with an operable glazed cover in winter, transforming the courtyard into an atrium. Their results showed a reduction of the heating demand when the buildings have a courtyard covered by a glazed 
roof in the winter, and significant benefits when used open in the summer.

Table 1: Comparison of Energy Intensity Use between the models. (Taleghani et al, 2013)

\begin{tabular}{lcc} 
& Courtyard & Atrium \\
\hline Building II Total heating energy & $35 \mathrm{kWh} / \mathrm{m}^{2] \star}$ & $26 \mathrm{kWh} / \mathrm{m}^{2]}$ \\
\hline Building III Total heating energy & $43 \mathrm{kWh} / \mathrm{m}^{2] \star}$ & $30 \mathrm{kWh} / \mathrm{m}^{2]}$ \\
* data extracted from bar chart, values are approximate.
\end{tabular}

Their results also explain the benefits of the internal courtyard to reduce the temperature in the summer without using air conditioning. This could be considered as a strategy to reduce the electrical peak loads in the summer and help reducing the stress of the electrical grid. Their research was based on the climate of De Bilt $\left(52^{\circ} \mathrm{N}, 4^{\circ} \mathrm{E}\right)$, representing the climate of the Netherlands. It is important to note that their coldest winter day of the year was set at $1^{\circ} \mathrm{C}$, a much higher temperature than the ones that can be reached in Toronto. The implications might be more extreme than in one located in The Netherlands. In any case, their findings show that the use of a hybrid open/close glass cover could offer benefits on the energy use reduction. 


\subsection{Literature review summary}

Internal courtyards are found in many parts of the world and throughout many civilizations. It has been a design feature that pleased the needs of people throughout the ages. They have been used culturally as well as programmatically; they had brought light into the house and had separated the public from the private space. It was used to define areas for gender separation, and as an extension of the living rooms. People made good use of the courtyards throughout cultures and time proving an inherent value of such intervention.

Internal courtyards mostly found in hot climate locations, and their use in cold climate areas has not been studied much, even though there are examples. The short days and cold temperatures don't provide extensive time to be outdoors, limiting the possibilities to exercise and the health benefits of sun exposure and fresh air. Internal courtyards had shown to be a protective feature in colder locations providing shelter from the wind while generating a microclimate that extends the days of outdoor activities. Existing examples of internal courtyards provide information regarding the increase of outdoor days in some locations of the world but that information is concentrated in Northern Europe examples.

Vernacular architecture provided the lead to investigate deeper about the use of internal courtyards in current times. Research has shown that according to the location, the courtyard's height and configuration changes either to shelter from the sun, or to take the most advantage of it. The internal courtyard has also been used to maximize and minimize the amount of light into the building, and with the combination of fenestrations and landscape has provided passive 
strategies to improve the comfort. The lack of information for a Toronto setting provides an opportunity to combine, and build upon existing information from other regions.

Row houses had shown to be an archetype with long tradition in Canada. Brought by early immigrants from Europe currently accounts for more than the $8 \%$ of the existing housing stock in the city. This archetype provides an affordable option in a highly priced housing market like Toronto. It also offers a response to density increase and energy reduction in a larger scale.

Conventional row houses had shown that natural light is compromised, generating dark areas that have to be lit artificially throughout the day. Few examples that resolve these issues have been found.

In larger buildings with internal courtyards, double and triple glazed windows don't show major differences on the overall energy performance when the courtyard is one story high. Orientation of the courtyard doesn't seems to be a major factor neither, but width to depth, height over width and window to wall ratios do. These factors influence the hours of illuminance as well as the cooling and heating loads.

The internal courtyards have proven to be noise buffers, with the height of the courtyard as the major factor in reducing the street noise, while the width and depth is not so important to reduce the noise levels inside the courtyard. In a growing city like Toronto, the internal courtyard provides good response for houses located in areas with traffic and street noise. 
An accessible outdoor space with low levels of noise, the increase of the hours of illuminance inside the house and the potential use of passive ventilation strategies can contribute positively to the wellbeing of the dwellers and provide an alternative solution to environmental and urban issues. The implications of internal courtyards in row houses have not been studied within a building science perspective and there is not available data regarding the influence of them in row houses located in Toronto.

\section{Research questions}

The purpose of this study is to examine the potential benefits of an internal courtyard. Assuming an architectural value to the internal courtyard, this study aims to understand the implications of such design on the energy performance, natural light and lighting consumption. The research questions are:

- What are the energy performance, the natural daylight and lighting consumption implications of an internal courtyard in a row house located in Toronto?

- What is the optimal configuration of a courtyard in a row house considering the energy performance, daylight improvement and electrical consumption? 


\subsection{Objectives}

Focused on a Toronto setting, the main goals of this research project are:

- Understand some variables that could affect the energy performance of row houses with internal courtyards.

- Understand the influence of an internal courtyard in the hours of illuminance of a row house.

- Develop performance and design information to be applied in new construction and in retrofits of existing row houses.

This research is also intended to contribute to the understanding of some passive solar house design parameters. It also aims to provide a useful tool to integrate architecture design and energy performance. It is expected to provide valuable design guidelines regarding the inclusion of internal courtyards and their influence in the energy performance and the interior lighting. 


\section{Methodology}

To find the optimal configuration of a courtyard in a row house considering energy performance, light consumption and luminance levels, this research will analyze four different courtyard footprints with four window to wall configurations on each. This process will be repeated positioning the house to the North, South, East and West. A total of 64 iterations of houses with courtyards and 4 base cases will be used in this research.

The analysis will be based on a retrofitted row house located in Toronto. The size and massing of this retrofit is used to represent a typical row house in Toronto with the recommended settings for an internal courtyard located in a cold climate:

- One story high courtyard: As recommended by Muhaisen, 2006, the best performance obtained in the summer and winter for colder climates is to be a one-story internal courtyard.

- Located in the middle of the row house

The information will be also processed according to a set of priorities alternating the importance of one variable over the other. This process will help understand if there are certain configurations that are better for one goal or if there are configurations that suit well to multiple ones.

\subsection{Existing house}

The analysis will be based on an existing property located in Toronto originally built in 1889. The house has a flat roof and it is located in the second and third 
levels with a footprint of $81 \mathrm{~m}^{2}(872 \mathrm{sf})$ in the lower level and $87 \mathrm{~m}^{2}(937 \mathrm{sf})$ in the upper level (Figure 26, Figure 27 and Appendix H). In the ground level the property has a store of $118 \mathrm{~m}^{2}$ (1270 sf) but it will not be considered in this analysis. A simplified version of the original drawings is used for the simulation (Figure 35 and Figure 36).

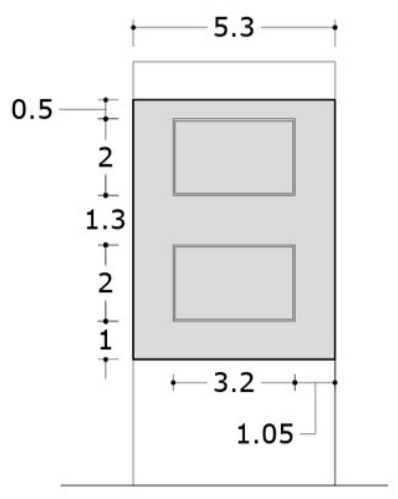

Front Elevation

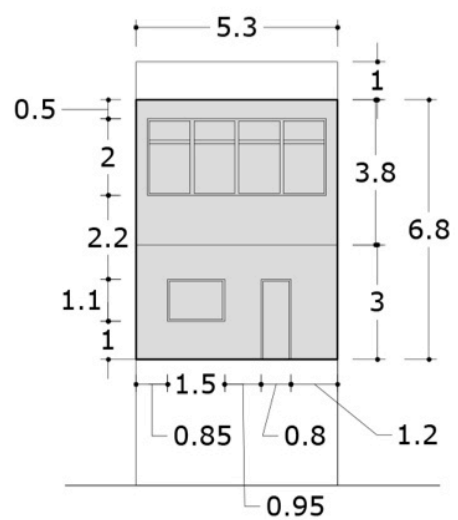

Back Elevation

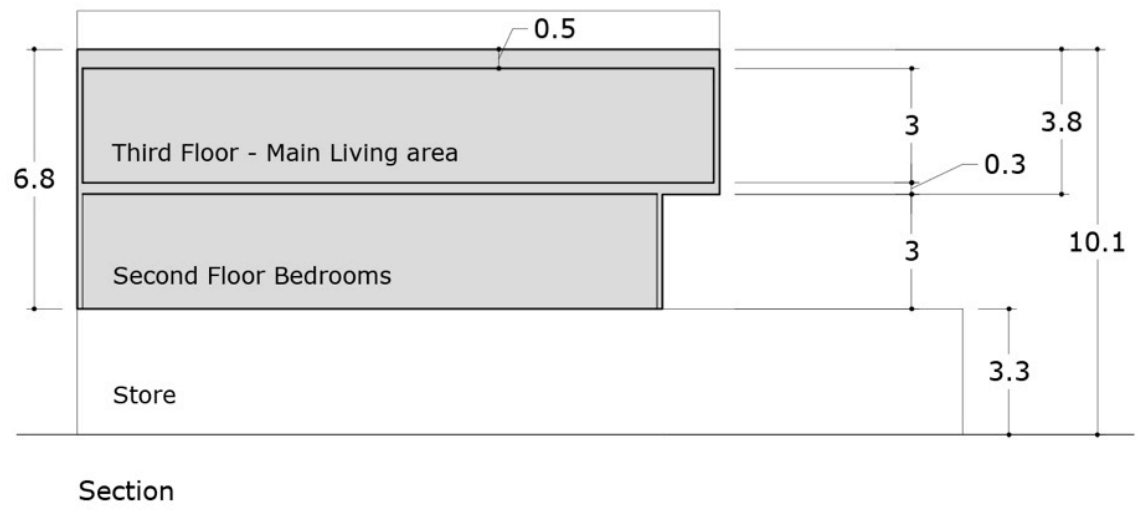

Figure 35: Elevations and section of the existing house. Units are in meters. 


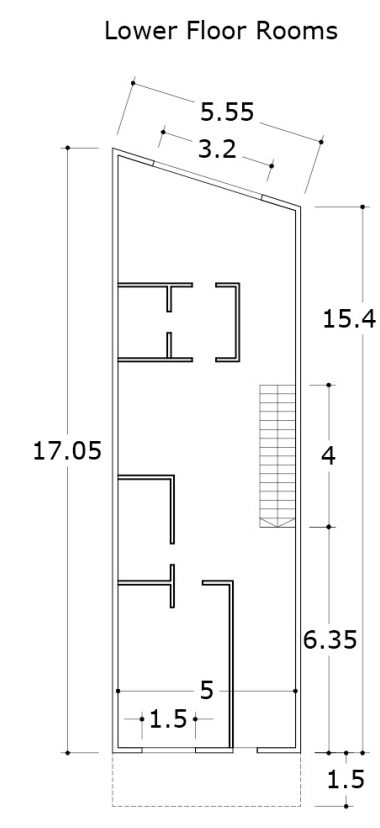

Upper Floor Living Areas
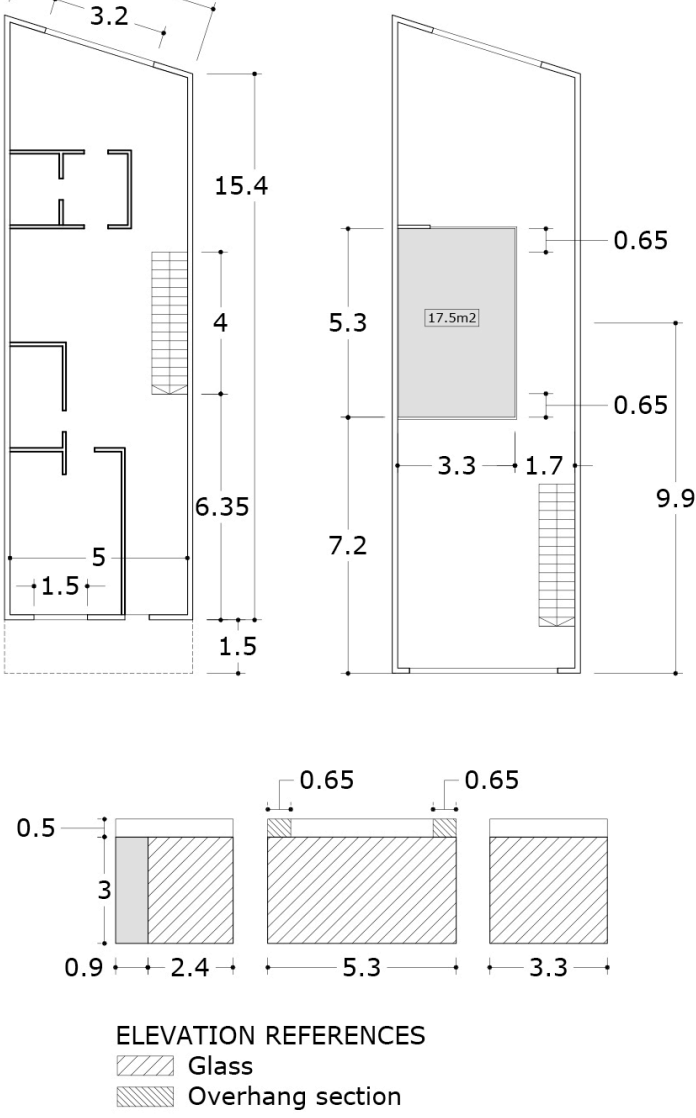

Figure 36: Plans and elevations of the existing house. Units are in meters.

\subsection{Base cases}

If the orientation of the house changes, the way the weather influences the energy performance and the illuminance changes as well. To understand the implications of internal courtyards in the energy performance and the hours of illuminance, one base case will be simulated for each orientation (Figure 37). The four base cases do not have an internal courtyard and the results from the 64 options will be compared to it own base case. It is important to note that the inclusion of an internal courtyard will reduce the space volume to be conditioned. This study intent is to analyze existing practices and to provide 
information when including and internal courtyard in an existing design that does not have one.
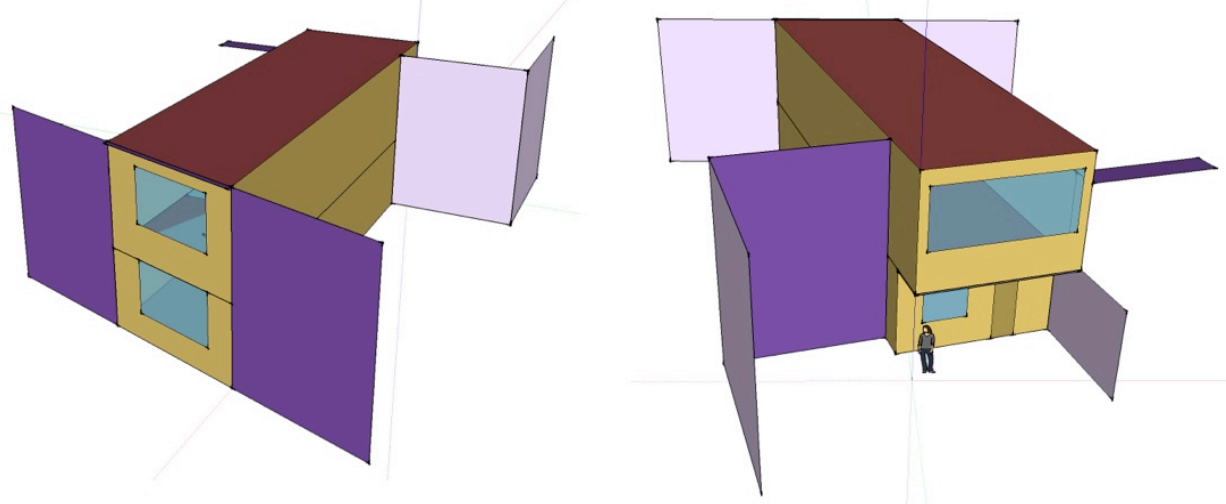

Figure 37: Base case model based on the existing houses but without an internal courtyard

\subsection{Layouts}

The internal courtyard introduces natural light in a part of the house that otherwise has no natural light anytime in the year. In a classic row house, the living and dining rooms, and the kitchen are located in the lower floor. The rooms are located in the upper floor, facing the front and back of the house. The space between the rooms either accommodates the washroom or a third room without a window.

The only light source on the upper floor are the windows from the bedrooms, leaving a dark area throughout the day in the middle of the house. This has mainly to do with the program, which requires walls for privacy. In this classic distribution, the inclusion of a courtyard replaces the room in the middle. The inclusion of an internal courtyard would provide three bedrooms; all of them smaller but with windows. The courtyard would have an access in the corridor or through the bedrooms (Figure 38). For this study this layout is called Layout 2. 
Without an

internal

courtyard

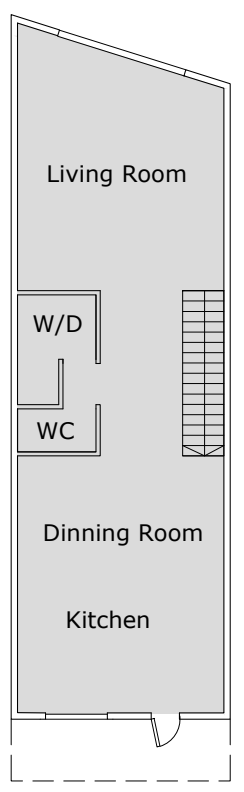

Lower Floor

Main living area

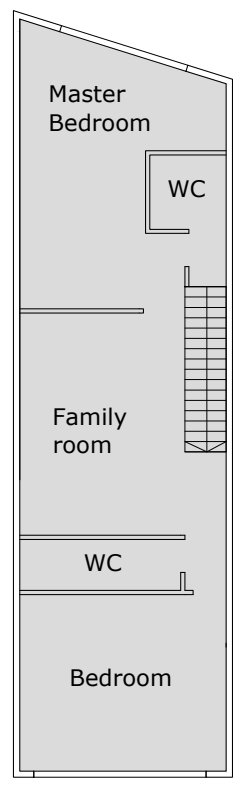

Upper Floor Bedrooms
Including the internal

courtyard

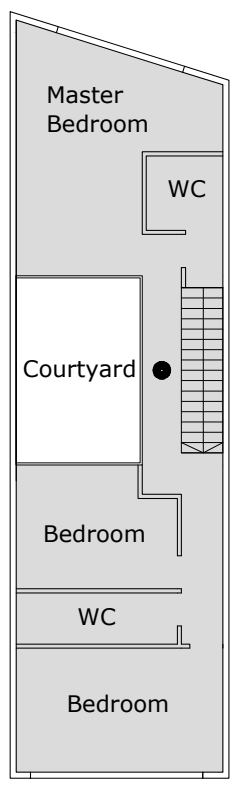

Upper Floor Bedrooms

- Illuminance
sensors

Figure 38: Layout 2 - Classic. Bedrooms are in the upper floor and the living are is in the lower floor.

An alternative layout configuration provides a different distribution of spaces.

For example, the bedrooms and washrooms could be located in the lower level and on the upper level the living/kitchen area conceived as an open concept space with access to a terrace or to a deck. In this configuration the row house without a courtyard has the advantage of getting light from the back and front, as the open concept doesn't require any wall to obstruct the light coming from the windows (Figure 39). 
Without an

internal

courtyard

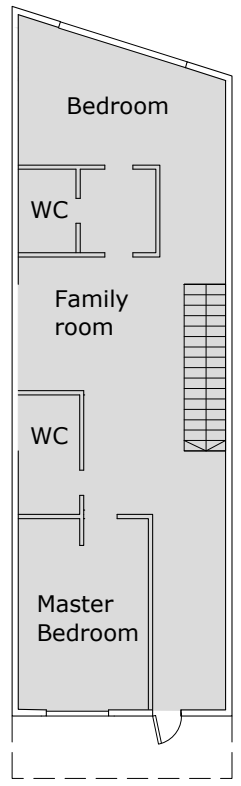

Lower Floor

Main living area

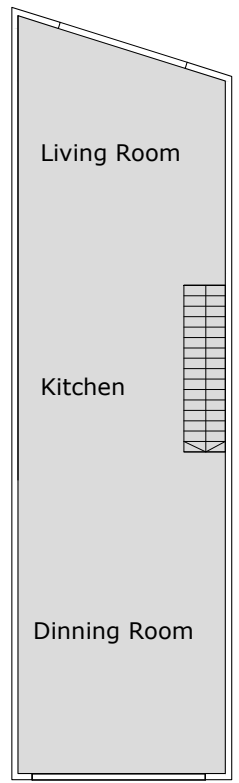

Upper Floor Bedrooms
Including the internal courtyard

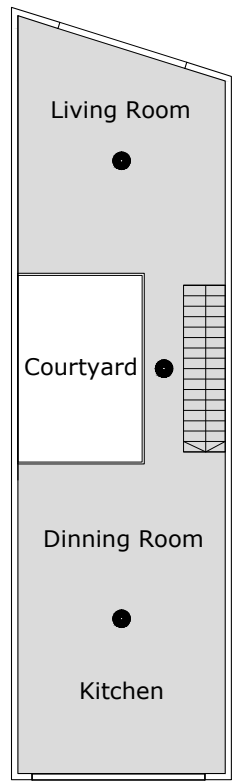

Upper Floor Bedrooms

- Illuminance sensors

Figure 39: Layout 1. The bedrooms are located in the lower floor and the living area is located the upper level, as in the existing row house in The Junction, Toronto.

For that reason it is expected that this layout will show lower improvements on the hours of illuminance compared to Layout 2. For this study, this configuration is called Layout 1, and it is the layout analyzed.

This is also the configuration of the existing row house in Toronto, which includes an internal courtyard (Figure 26 and Figure 27). The sensors will be set according the minimum recommended values. The Chartered Institution of Building Services Engineers recommends 100 lux for movement and casual seeing with only limited perception of detail (CIBSE 1994), while the Illuminating Engineering Society of North America (IESNA) considers 100 lux to be used for working spaces where simple visual tasks are performed (Cuttle, 2003). The 
analysis will consider 100 lux as the threshold to calculate the amount of hours of light inside the house.

Lighting metrics include a wide range of options like illuminance and luminance while the location of the sensors adds complexity to the results. The study will not explore this complexity and to simplify the analysis the threshold of 100 lux will be used in light sensors located near the floor. This threshold of 100 lux can is considered a minimum levels to walk safely and thus considered as valid minimum requirement.

\subsection{Simulation model}

EnergyPlus is used to simulate the options due to its accuracy, flexibility and high level of input detail. OpenStudio plugin for SketchUp is used to model the 3D buildings. EnergyPlus is a dynamic simulation program developed by the US Department of Energy and its partner agencies (Crawley, 2004):

- Uses sophisticated simulation techniques, like sub-hourly timesteps, allowing also to use more accurately transient interactions (Zirnhelt, 2013). For each time-step in the simulation, positive values are shown as additions and negative values are shown as removal (EnergyPlus, 2012). For this research the time-steps for the energy models were set at 30/hour.

- OpenStudio plugin allows using Sketchup to model the configurations in a user-friendly three-dimension interface.

- Illuminance sensors can be connected to the light schedule, enabling them to turn off the artificial light if certain hours of illuminance are reached in the location they are set.

- Heating and cooling load calculation as well. 
Solar gains are also considered in the simulation. In EnergyPlus the window transmitted solar variable is subtracted so that the glazing heat gain represents the transfer of all heat through the window excluding beam and diffuse shortwave solar heat effects. (EnergyPlus, 2012). The glazing information used in the simulations follows a product found in the local market with detailed options for windows specifications including transmittance, reflectance and emissivity data utilized by Zirnhelt (2012).

The Ontario Building Code (OBC) Supplementary Standard SB-12 is the latest update to building code requirements for low rise, single-family residential buildings. The simulations will be modeled based on SB-12. This standard offers a series of prescriptive compliance packages combining mechanical systems and building envelope specifications aiming to reach an energy performance improvement of 30\% compared OBC-2006 (Ontario Ministry of Municipal Affairs and Housing, 2010) (Appendix G).

To compare and analyze the different configurations according to the research questions, the energy simulation tool has to be able to model both thermal loads and lighting hours of illuminance. The artificial light in the area surrounding the internal courtyard has to be controlled by the hours of illuminance to be able to understand the benefits in the increase of natural light, and solar gains have to be included in the simulation to understand the implications of the window to wall ratio in the heating and cooling loads. The simulations are based from a recent research on various dwelling archetypes in Toronto by Jermyn (2014). The energy model is separated in two zones, one for each floor, openly connected via the stairs. Ventilation was added at each 
zone level. No HRV has been included in the simulation, as Package A of the OBC SB-12 does not require it. An air tightness value is not required by the OBC SB-12 either, but the required ventilation was determined from OBC Part 9, Sentence 9.23.3.3(1), Table 9.23.3.3, and modeled to an outdoor air flow rate of $0.3 \mathrm{~m}^{3} / \mathrm{s}$.

EnergyPlus requires for each inter-zonal opening (doors, hallways, and staircase) to be modeled as surfaces. The staircase inter-zone was model as glass, with very high transmittance, high emissivity, high long wave transmittance and very low thermal resistance as done as the calibrated model of Zirnhelt (2012). The research considers the floor between the ground floor store and the house as adiabatic.

\subsubsection{Envelope}

All the cases use the same wall and roof assemblies, windows, doors, etc., and comply with the $\mathrm{OBC}$ requirements from the Package A of the Supplementary Standard SB-12. a for ZONE 1. With less than 5000 heating degree days, Toronto is located in ZONE 1. From the table 2.1.1.2 of the SB-12 for heating equipment with AFUE $\geq 90 \%$ the $\mathrm{OBC}$ requirements are the following: 
Table 2: Base case. SB-12 Package A requirements and specified material for the wall assembly.

Total Wall

\begin{tabular}{|c|c|c|c|}
\hline & Required & Specified- Nominal RSI & Thickness \\
\hline Wall & $4.23 \mathrm{~W} / \mathrm{m}^{2} . \mathrm{K}(\mathrm{R} 24)$ & $\begin{array}{c}4.23 \mathrm{~W} / \mathrm{m}^{2} . \mathrm{K}-0.16 \mathrm{~m} \\
\text { fiberglass }\end{array}$ & $0.24 \mathrm{~m}$ \\
\hline Roof & $5.46 \mathrm{~W} / \mathrm{m}^{2} . \mathrm{K}(\mathrm{R} 31)$ & $\begin{array}{c}5.46 \mathrm{~W} / \mathrm{m}^{2} . \mathrm{K}-0.21 \mathrm{~m} \\
\text { fiberglass }\end{array}$ & $0.29 \mathrm{~m}$ \\
\hline $\begin{array}{l}\text { Exposed } \\
\text { floor }\end{array}$ & $5.46 \mathrm{~W} / \mathrm{m}^{2} . \mathrm{K}(\mathrm{R} 31)$ & $\begin{array}{c}5.46 \mathrm{~W} / \mathrm{m}^{2} . \mathrm{K}-0.21 \mathrm{~m} \\
\text { fiberglass }\end{array}$ & $0.50 \mathrm{~m}$ \\
\hline
\end{tabular}

Table 3: Construction assemblies

\begin{tabular}{cccc} 
Exterior Walls & Roof & Window & Door \\
\hline Brick $100 \mathrm{~mm}$ & Shingle & Glass $6 \mathrm{~mm}$ & Thermal resistance \\
Brick $100 \mathrm{~mm}$ & OSB & Air gap $12 \mathrm{~mm}$ & $2.1 \mathrm{~m}^{2} . \mathrm{K} / \mathrm{W}$ \\
Fibreglass $160 \mathrm{~mm}$ & Fibreglass $210 \mathrm{~mm}$ & Glass $5.7 \mathrm{~mm}$ & \\
Lath $65 \mathrm{~mm}$ & Lath $65 \mathrm{~mm}$ & & \\
Plaster $12.7 \mathrm{~mm}$ & Plaster $12.7 \mathrm{~mm}$ & &
\end{tabular}

The influence of windows in the energy loss and heating gains is essential in the overall energy performance and hours of illuminance of a building. "A superior method of modeling windows is achieved when sufficient data is available and transmission, reflection and absorption is calculated as a function of wavelength. 
EnergyPlus automatically generates angular optical properties from spectral average input" (Zirnhelt, p. 37, 2012).

This insulation values is modeled as fiberglass and the envelope assemblies are set as follows:

- $50 \mathrm{~mm} \times 100 \mathrm{~mm}(2 " \times 6$ ") stud wall with fiberglass insulation between the studs

- $300 \mathrm{~mm}\left(1^{\prime}\right)$ I joist roof with fiberglass insulation

The glass specifications used in the simulation are listed on Table 4.

Table 4: Windows specifications

\section{Glass $5.7 \mathrm{~mm}$}

Solar transmittance at Normal Incidence

0.770

Front side solar reflectance at normal incidence

0.069

Back side solar reflectance at normal incidence

0.070

Visible transmittance at normal incidence

0.883

Front side visible reflectance at normal incidence

0.080

Back side visible reflectance at normal incidence

0.080

Infrared transmittance at normal incidence

0

Front side infrared hemispherical emissivity

Back side infrared hemispherical emissivity

Conductivity $[\mathrm{W} / \mathrm{m} \cdot \mathrm{k}]$ 


\subsubsection{Weather file and run period}

The EnergyPlus model is simulated in Toronto, located at 43.7 degrees latitude and an elevation of $173 \mathrm{~m}$. According to National Resources Canada, Central and Southern Ontario (Toronto) is located in Zone B for the energy star qualification (NRCAN, 2014):

$$
\text { Zone B: }>3500 \text { to }<=5500 \text { HDDs (Heating Degree Days) }
$$

The simulations were carried out using the Canadian Weather for Energy Calculations (CWEC), which follows the ASHRAE WYEC2 (Weather Year for Energy Calculation 2) format and were derived from the Canadian Energy and Engineering Data Sets (CWEEDS) of hourly weather information for Canada from the 1953-1995 period of record. (Numerical Logics, 1999). The simulations used a one year run period.

Table 5: Weather data report from EnergyPlus.

Program Version and Build EnergyPlus-Darwin-64 8.1.0.009, YMD=2014.11.22 22:31

\begin{tabular}{rr}
\hline RunPeriod & SINGLE YEAR SIMULATION \\
\hline Weather File & Toronto Int'I ON CAN WYEC2-B-04714 WMO\#=716240 \\
\hline Latitude [deg] & 43.67 \\
\hline Longitude [deg] & -79.6 \\
\hline Elevation [m] & 173.00 \\
\hline Time Zone & -5.0 \\
\hline
\end{tabular}

Hours Simulated

[hrs]

8760.00 


\subsubsection{Hours of illuminance}

To understand the influence of an internal courtyard on the hours of illuminance the following metrics are considered:

- The illuminance level difference between the row house without an internal courtyard and the ones with internal courtyards. This metric is analyzed as the amount of hours of natural light over 100 lux in three locations of the upper level: in the centre of the front and back rooms and in the middle of the house near the stairs. The sensor is located on the floor.

- The reduction of electricity use when the row house includes an internal courtyard. This is considered as the amount of energy saved by not turning on the lights when the hours of illuminance reach above 100 lux. This metric is governed by the established lighting schedule.

The artificial light is scheduled according to the use of a family of 4, two parents and two kids. In EnergyPlus, when the sensor perceives certain amount of illuminance, the artificial lights are turned off even tough according to the schedule they are supposed to be on (EnergyPlus, 2013). Minimum hours of illuminance recommended by CIBSE for movement and casual seeing (Cuttle, 2003) is set at 100 lux. The schedule then is overridden when the light sensor located in the hallway reaches 100 lux.

The sensors are located at a height of $50 \mathrm{~mm}$ from the floor. The sensors were located in the same place for all the courtyard configurations. The illuminance sensor controls $25 \%$ of the zone regarding the activation/deactivation of the lights. This means that the sensor turns off $25 \%$ of the lights of that floor when the illuminance level passes the threshold of 100 lux. 


\subsubsection{Internal loads: Lighting, appliances and people}

The lighting consumption is calculated at $1.93 \mathrm{~W} / \mathrm{m}^{2}$ in the main floor area and 3.07 W/m ${ }^{2}$ for the bedrooms lower floor. These information is taken from a calibrated model of the house from Zirnhelt (2013). As mentioned before, the sensors will turn off $25 \%$ of the upper floor lights when they measure an illuminance above 100 lux overriding the established schedule. But when the illuminance level within the hallway is below 100 lux, the lights will turn on according to the following schedule:

Table 6: Lights schedule and intensity

\begin{tabular}{ccc}
\hline & $\begin{array}{c}\text { Lower Floor - Bedrooms } \\
3.07 \mathrm{~W} / \mathrm{m}^{2}\end{array}$ & $\begin{array}{c}\text { Upper Floor - Main Living Area } \\
\text { Lights }\end{array}$ \\
\cline { 2 - 3 } are on & from 6:45AM to 7:45AM & from 7AM to 8AM \\
\cline { 2 - 3 } & & from 12PM to 1PM \\
\hline
\end{tabular}

The appliances intensity and schedules as well as the people internal loads reflect the use of a typical house in Toronto and were taken from Jermyn's Centennial House energy model (2014). The internal loads from the appliances, the lights and the schedules are set the same throughout all the energy models.

\subsubsection{Equipment: Furnace, air conditioning and domestic hot water} A standard HVAC system was modeled, including a natural gas furnace and electric air conditioner with centralized forced air ventilation. The basic modeling information for the HVAC system comes from a calibrated model used by Jermyn (2014). The furnace is a natural gas fired and the air-conditioning has an external unit condenser. The main components of the HVAC used in the 
simulation include air terminals, furnace fan, heating coil and cooling coil. There is one centrally located thermostat in the upper floor with a heating set point at $21^{\circ} \mathrm{C}$ and a cooling set point at $24^{\circ} \mathrm{C}$. The furnace minimum annual fuel utilization efficiency (AFUE) required by the package A of the OBC SB-12 is $90 \%$ for a natural gas furnace (OBC SB-12, 2012)

\subsubsection{Energy model verification}

To verify the energy model, an energy simulation using the existing house is modeled following the exact orientation and courtyard size. The results are compared with the energy data from the utility bills provided by the owners of the existing row house. The natural gas information was not useful as the meter is shared with the store located on the ground floor.

The average electrical bill of their monthly consumption has been between $\$ 150$ and $\$ 200$ bi-monthly for the dwelling (G. Vaisman, personal communication, August $\left.13^{\text {th }}, 2014\right)$. As there are many costs associated with the electrical bill, the monetary value does not reflect the energy use. To extrapolate the energy metric, it is needed to separate the data provided by the utility company according to the associated costs. A detailed electrical bills from another house located in Toronto was used to separate the matrix of costs (Appendix E) and the results showed that existing house used $4756 \mathrm{kWh}$ of electricity. The simulation results showed an estimated annual electrical use of $4591.7 \mathrm{kWh}$ (Figure 40 ) or a $6 \%$ difference compared to the simulated results. This value is considered acceptable to validate the energy model. 


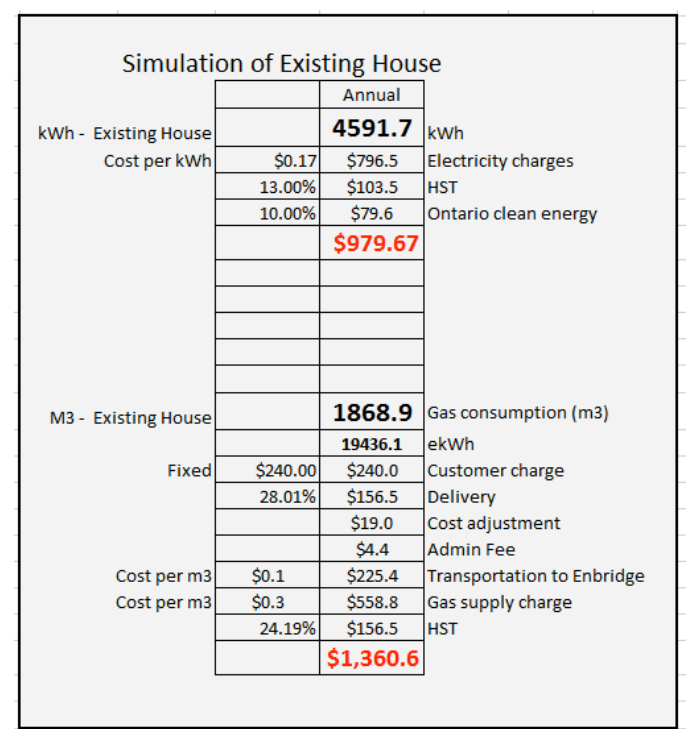

Figure 40: Predicted annual energy use and cost of the existing house.

\subsubsection{Courtyard geometry and height}

The contribution of the geometrical design of a courtyard is a key component of this research. As in the existing house, the courtyard is located in the upper floor; the height is designed at $3 \mathrm{~m}$ high and the roof assembly at $0.5 \mathrm{~m}$ high. The stairs and passageway are re-designed to have $2 \mathrm{~m}$ wide, leaving the dimensions of the courtyard to a maximum of $3 \mathrm{~m}$.

The width of the courtyard is indirectly governed by the $\mathrm{OBC}$, as it only requires for the fenestrations to have a minimum distance of $1.2 \mathrm{~m}$ from a party wall (OBC, 2006). The length of the courtyard has no restrictions.

Four iterations with different width to length ratios are modeled (Figure 41). It is considered by the writer of this research that these configurations cover a realistic maximum and minimum dimension that would be commonly designed for an internal courtyard in a lot of these characteristics:

- Courtyard 1 - 1:1.5 (Rectangular)

- Courtyard 2 - 1:1 (Squared)

- Courtyard $3-1: 2$ (Rectangular)

- Courtyard 4-2:1 (Rectangular) 
Courtyard \#1

Rectangular

$1: 1.5$

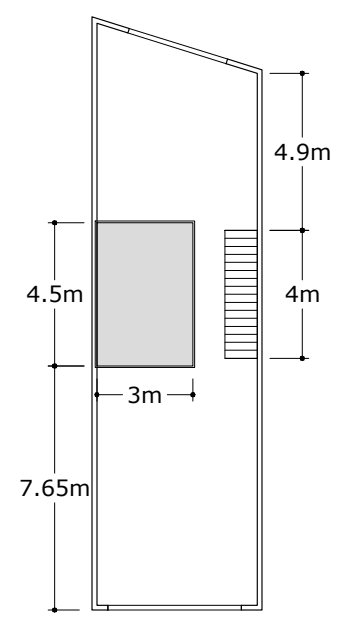

Courtyard \#2 Squared

$1: 1$

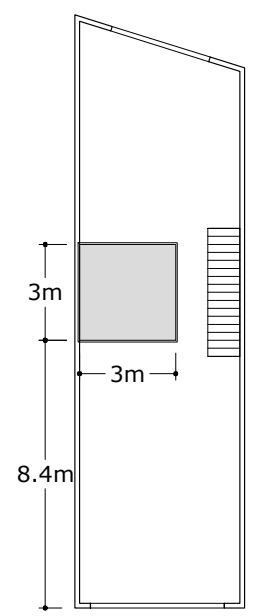

Courtyard \#3 Rectangular Vertical $1: 2$

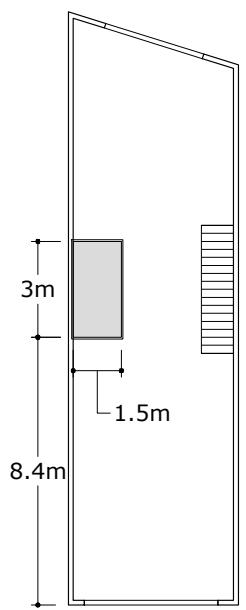

Courtyard \#4 Rectangular Horizontal

2:1

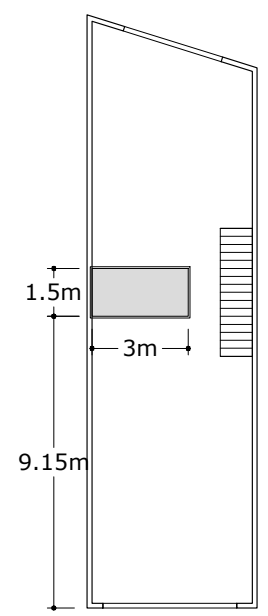

Figure 41: Courtyard footprint configurations.

\subsubsection{Window to wall ratio}

Each courtyard plan configuration has a similar window pattern that follows standardized window parameters. Each courtyard has 4 different window to wall ratios and as each courtyard has different size, the final window to wall ratios differ. However they can be grouped into the following four ranges:

- A $73 \%-100 \%$

- B $55 \%-65 \%$

- C $36 \%-42 \%$

- D $20 \%-34 \%$ 
Courtyard \#1 Rectangular

$1: 1.5$
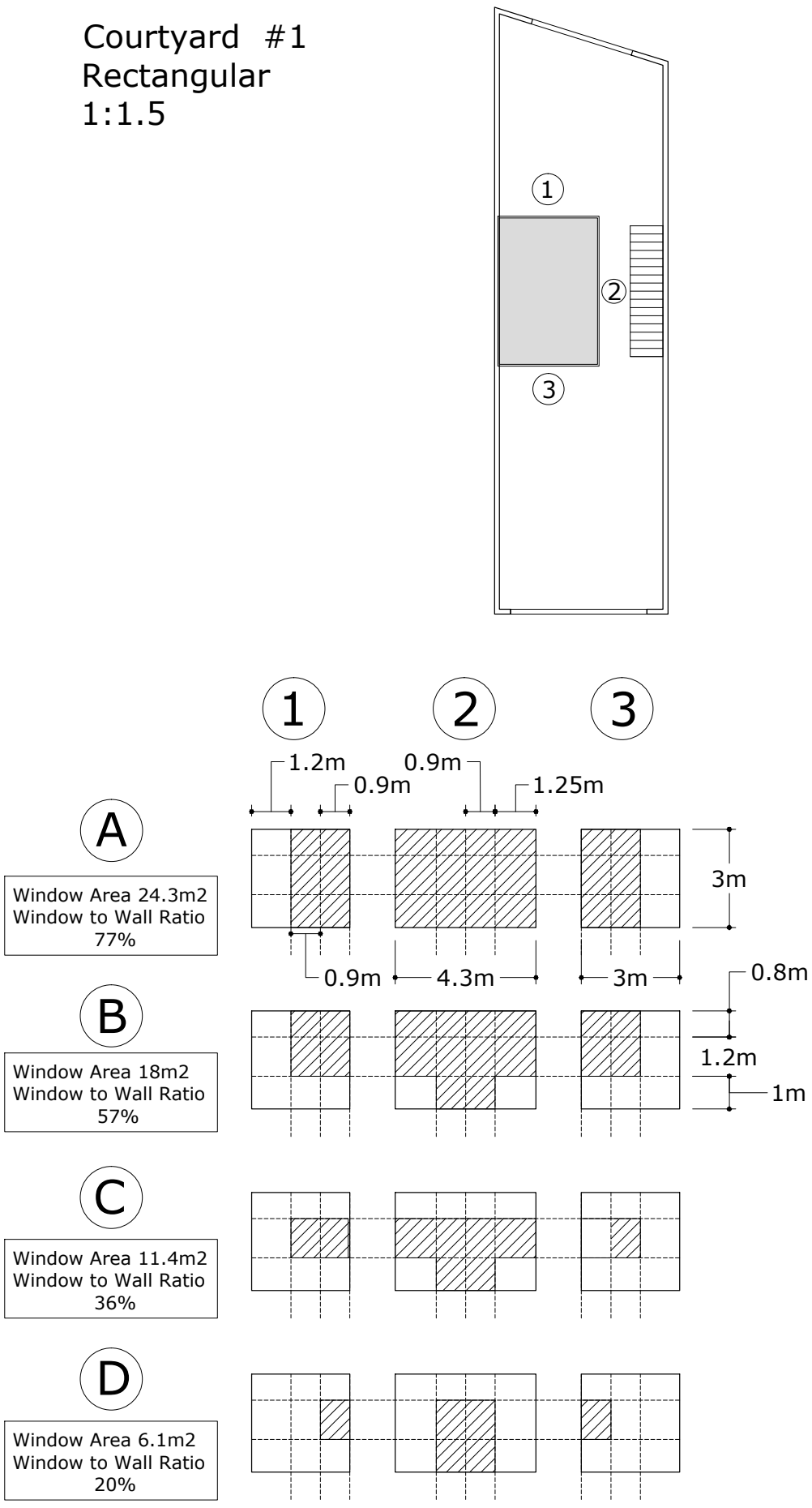

Figure 42: Courtyards configurations \#1 

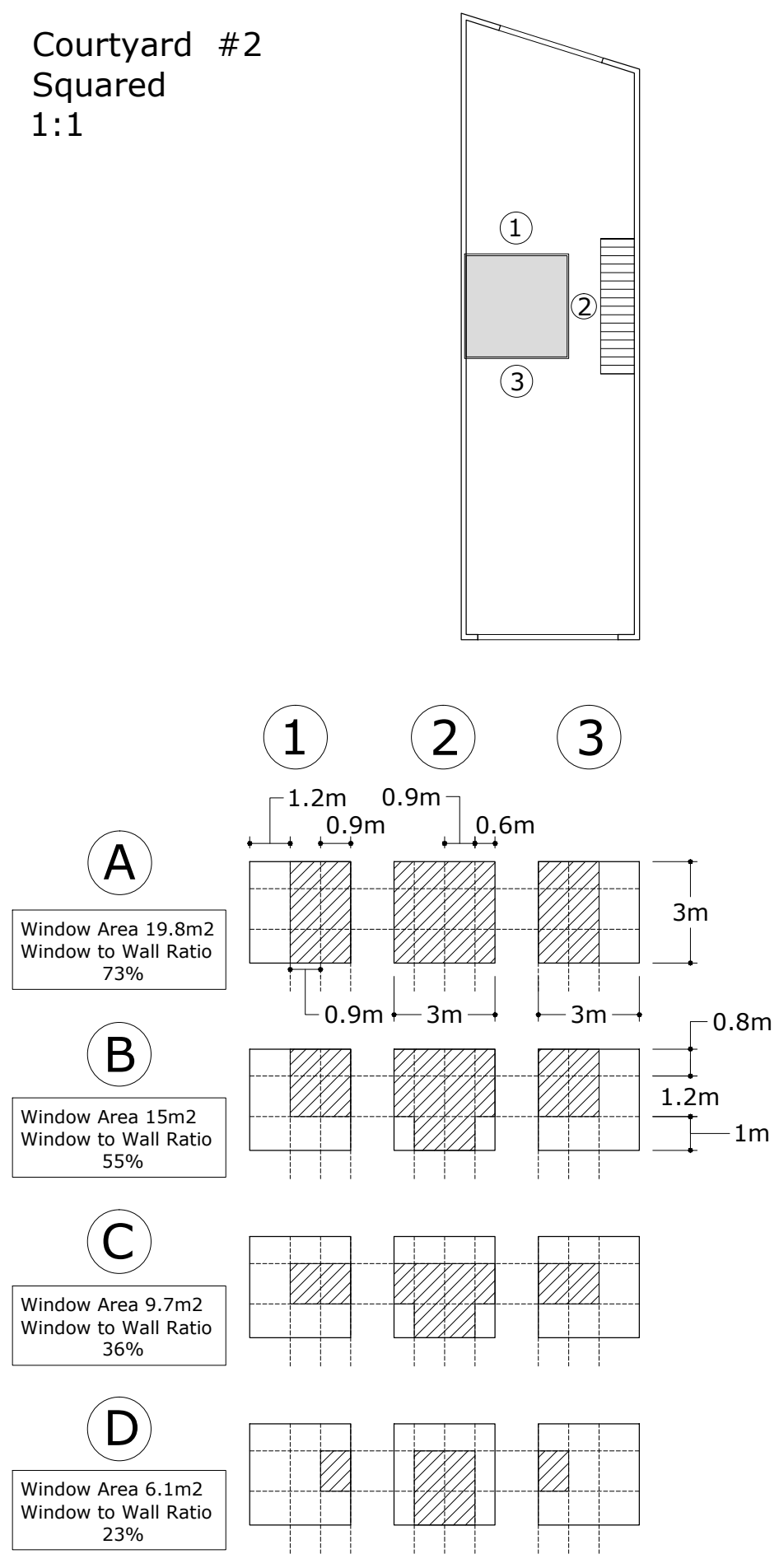

Figure 43: Courtyards configurations \#2 

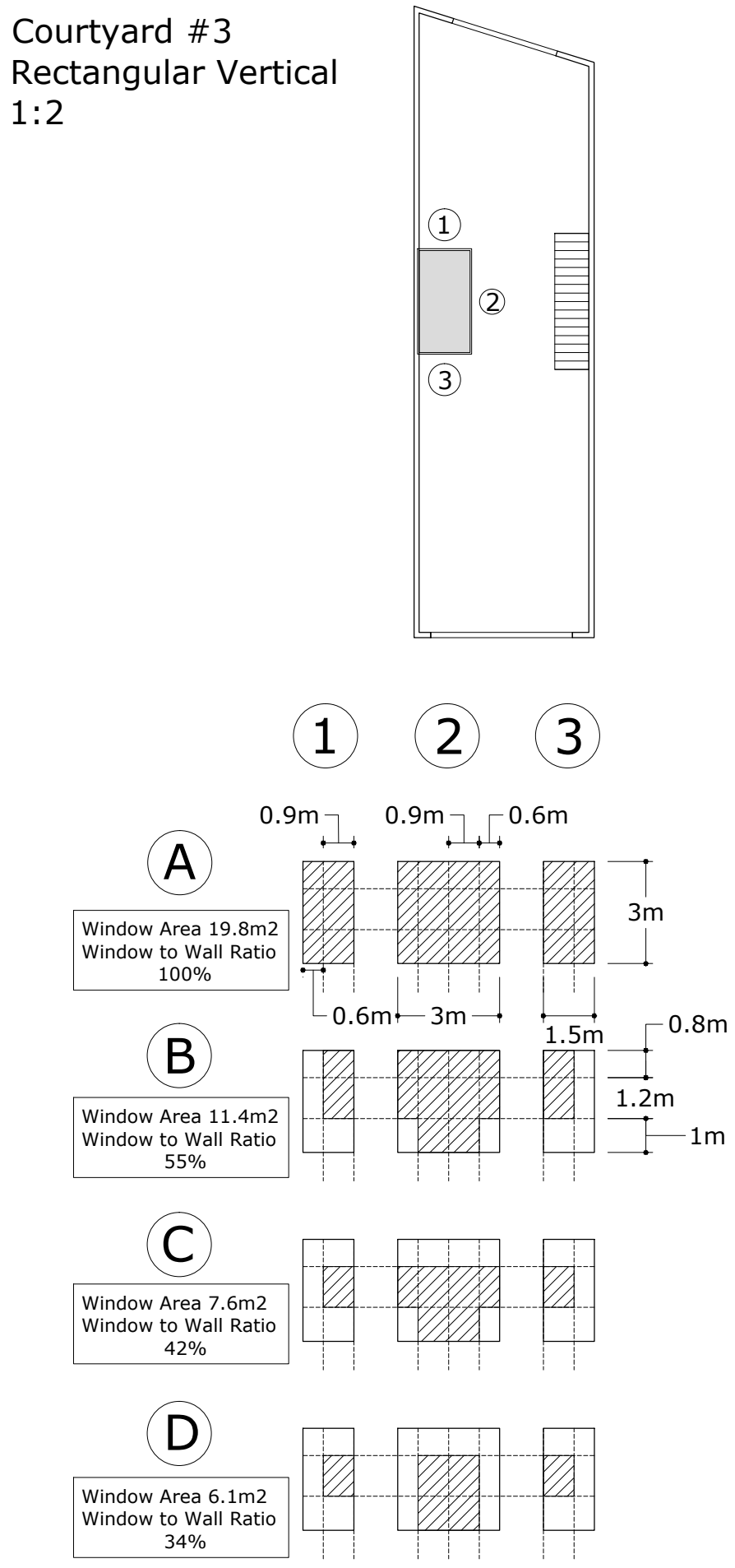

Figure 44: Courtyards configurations \#3 


\section{Courtyard \#4 Rectangular Horizontal 2:1}
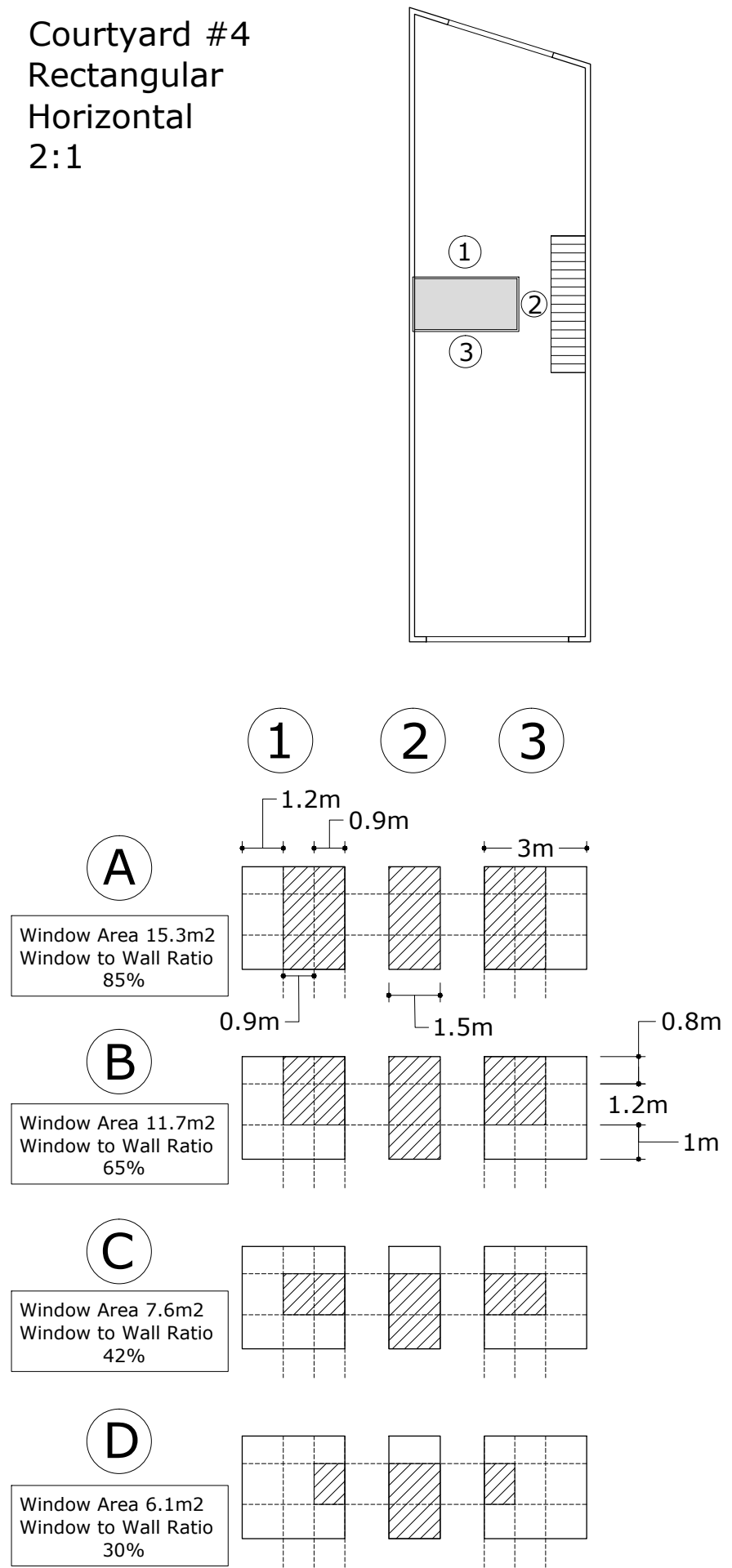

Figure 45: Courtyards configurations \#4 


\subsubsection{Orientation}

Toronto's urban fabric is

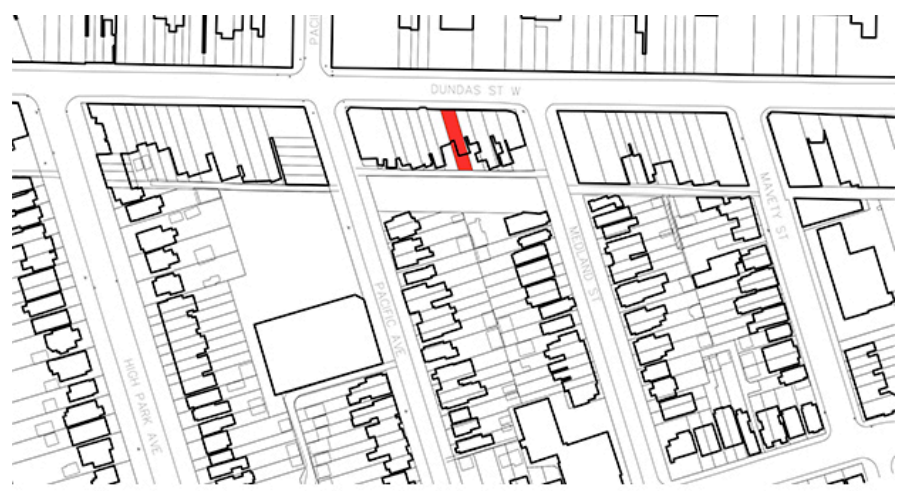

46). The existing house is

located in a street with an

Figure 46: Typical lot orientations in Toronto (City of Toronto, 2014)

uncommon orientation within the grid of Toronto. The front street is horizontal to the true north but the lot is angled to follow the $16^{\circ}$ grid (Figure 47). For the purpose of this research, the orientations

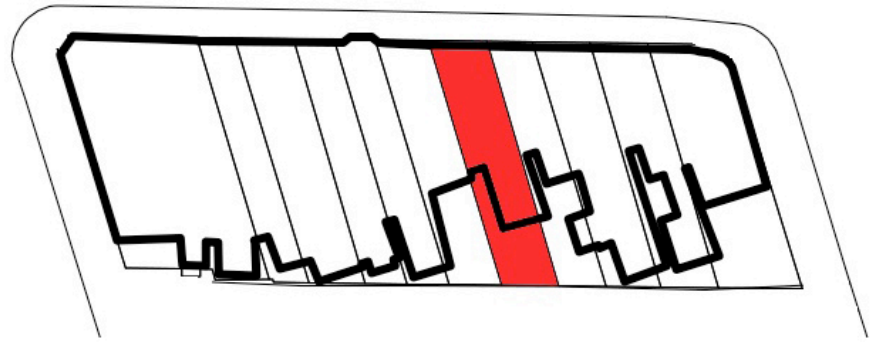

Figure 47: Existing row house and adjacent lots. (City of Toronto, 2014). analyzed are oriented to the true north axis. As found in the literature review, the first $20^{\circ}$ of rotation there is negligible influence (Muhaisen \& Gadi, 2006). To allow the use of the information in different locations, the iterations will be modeled within the N-S-E-W grid with no angle (Figure 48).

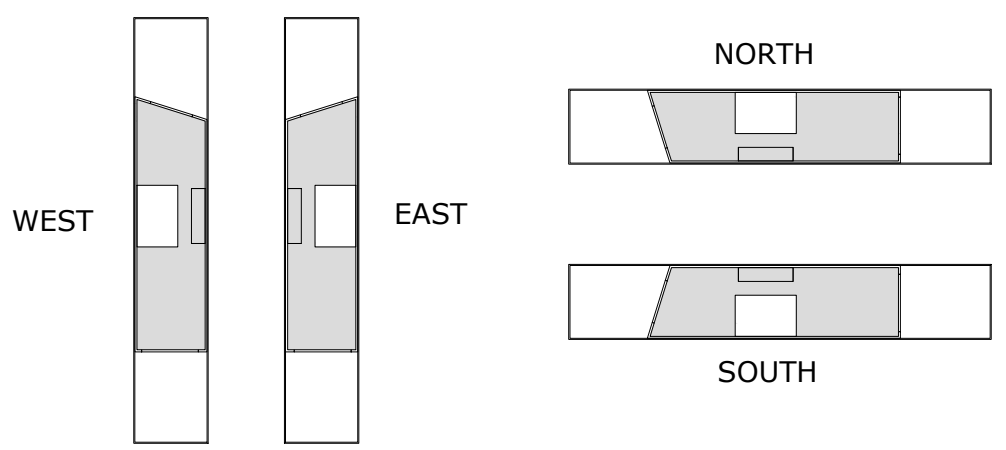

Figure 48: Courtyard location and lot orientations used in the energy model. 


\subsection{Performance indicators}

The main performance indicators used in this research are:

- Energy used by the artificial lights:

EnergyPlus model overrides the light schedule with the day lighting controls; it means that within the scheduled light use they are turned off when the natural light covers the illuminance level over 100 lux. The lighting summary report from EnergyPlus provides the outputs used for the analysis. From the interior lighting report, the outputs are compared to find the difference of artificial light use between the base case and the iterations.

- Amount of hours of natural light above 100 lux:

The EnergyPlus outputs show the number of hours when the calculated daylight illuminance at the sensor exceeds the daylight illuminance set point of 100 lux. This metric is used to compare the hours of natural light from the base case to the iterations results.

- Energy used by the heating system:

The natural gas used by the HVAC system shows the impact of the increased exposed surface and window to wall ratios on the heating load.

- Energy used by the cooling system:

The cooling loads show the impact of the window to wall ratio as the increase solar gains increase the cooling loads.

- Window heat gain and heat loss:

The inclusion of an internal courtyard increases the glazed area exposure to the sun, an indicator to consider solar passive design strategies. The heat removal shows the heat loss through the fenestrations. This is a relevant factor as whether the heat gains offset the heat losses in winter, or if in the summer increases the cooling load requirements. 


\section{Results}

\subsection{Benchmarks}

To understand the influence of an internal courtyard on the energy performance and hours of illuminance in a row house located in Toronto, the following variables are combined:

- Hours of illuminance - Incoming natural light in the middle of the house.

- Natural Gas - Heating energy demand.

- Electricity - Cooling energy demand and energy used by lights, appliances and plug loads.

- Configuration - Form of the courtyard plan.

- Window to wall ratio on the courtyard walls.

- Orientation of the property and the internal courtyard.

The first analysis focuses individually on the energy performance and the hours of illuminance, showing the influence of the variables on the sixty-four options altogether.

A second analysis combines the energy performance and the hours of illuminance in six sets of priorities. The goal of this analysis is to find the best performers regarding the value assigned to each variable. For example, if the energy for heating is considered the most important value, and the illuminance level is considered the second most important value, the results of this set of priorities will show which options are the best performers on heating energy use first, and second on hours of illuminance. 
If the second most important variable is the electrical use instead of the illuminance level, this new set of priorities will show which options are best on natural gas, and then on electrical use. This analysis tries to reflect the way design decisions are made while trying to represent different approaches when choosing an internal courtyard.

A third analysis will look at the influence of the internal courtyard regarding the solar heat gain and loss of the fenestrations located in the courtyard. These outcomes will help understand if the internal courtyards can be considered useful for passive solar strategies.

\subsection{Base cases}

Each orientation has a base case that was simulated as row house without an internal courtyard. Without including an internal courtyard, it was found that the orientation does not play a major role in the increase of hours of illuminance in the middle of the house. The base cases oriented to the South and North show 2.5\% higher hours of illuminance than the oriented to the East and West. The base case results show the best performance on hours of illuminance in the North and South options, with 3661 and 3659 hrs/yr above 100 lux on the sensor per year. It is followed very close by the East and West options with 3571 and 3570 hrs/yr each (Table 7). 


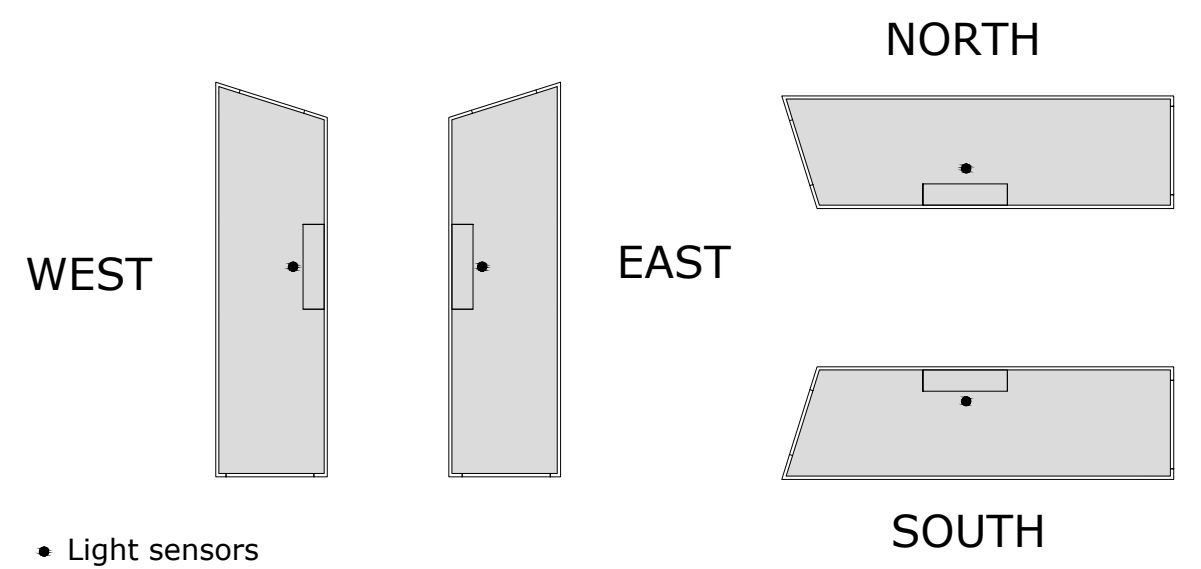

Figure 49: Location of sensor at base cases without courtyard

Table 7: Simulation results of the base cases with the neighbouring properties

\begin{tabular}{|c|c|c|c|c|}
\hline & SOUTH & EAST & NORTH & WEST \\
\hline $\begin{array}{c}\text { Illuminance } \\
\text { [hrs/yr] }\end{array}$ & 3659 & 3571 & 3661 & 3570 \\
\hline $\begin{array}{c}\text { Nat. gas } \\
\text { [kWh/yr] }\end{array}$ & 13214 & 12017 & 12053 & 12417 \\
\hline $\begin{array}{c}\text { Electricity } \\
\text { [kWh/yr] }\end{array}$ & 4489 & 4025 & 4564 & 4025 \\
\hline
\end{tabular}

Table 8: Simulation results of the base case without the neighbouring properties

\begin{tabular}{|c|c|c|c|c|}
\hline & SOUTH & EAST & NORTH & WEST \\
\hline $\begin{array}{c}\text { Illuminance } \\
\text { [hrs/yr] }\end{array}$ & 3663 & 3577 & 3663 & 3570 \\
\hline $\begin{array}{c}\text { Nat. gas } \\
\text { [kWh/yr] }\end{array}$ & 13158 & 12031 & 12275 & 12456 \\
\hline $\begin{array}{c}\text { Electricity } \\
\text { [kWh/yr] }\end{array}$ & 4497 & 4047 & 4558 & 4025 \\
\hline
\end{tabular}

To verify the influence of the neighbouring properties, the same orientations were simulated without them (Table 8). The East and West orientations result in a similar energy use and show minimal difference in the energy use when 
simulating them with and without the neighbouring properties. While the North and South base cases shows higher differences between them. In these cases the difference in the energy use for heating might be related to the position of the oblique façade, as it allows for higher sun exposure of the envelope on the North oriented base case (Figure 50).

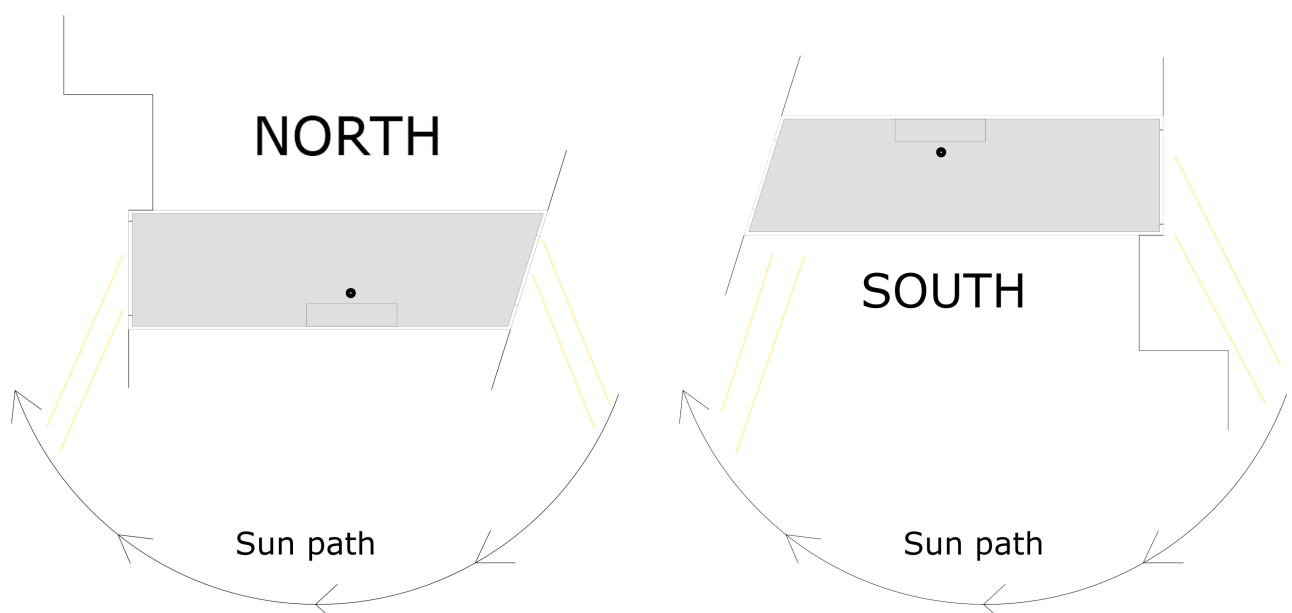

Figure 50: Influence of the envelope shape on the energy loads in winter

The North and South oriented base cases reflect the influence of the neighbouring properties. In the option with neighbouring properties, the North uses $8.8 \%$ less heating energy heating than the South. In the options simulated without the adjacent properties, the North uses $6.7 \%$ less energy for heating than the South. The energy use for cooling outcomes is very similar when considering the base cases with and without neighbouring properties (Table 7 and Table 8).

As expected, it has been found the orientation has an influence in the performance of the houses and to account for that, the analysis of the parameters for each orientation is always compared to their orientation base case. 


\subsection{Energy use for the lights}

The energy use simulated is based on the assumption that the house uses low energy lights (CFL/LED). For the floor with bedrooms (94m²-1012 sq.ft.) it was used $1.97 \mathrm{w} / \mathrm{m}^{2}$ of electricity use for lighting, which gives a total of 180 Watts, or 60 Watts per room. For the floor where the kitchen and living are (86m $2-926 \mathrm{Sf})$ it was calculated $3.1 \mathrm{w} / \mathrm{m}^{2}$ with a total of 265 Watts for the lights. These values are based on the CCHT Twin Houses models in Ottawa (Zirnhelt, 2013).

The results show that the energy saved in the use of artificial lights is very low. If the total energy used for lighting is compared to the energy use of lights, the savings range between $1.14 \%$ to $1.42 \%$ of energy per year. Figure 51 shows that the energy saved in the parameter is low across all the configurations.

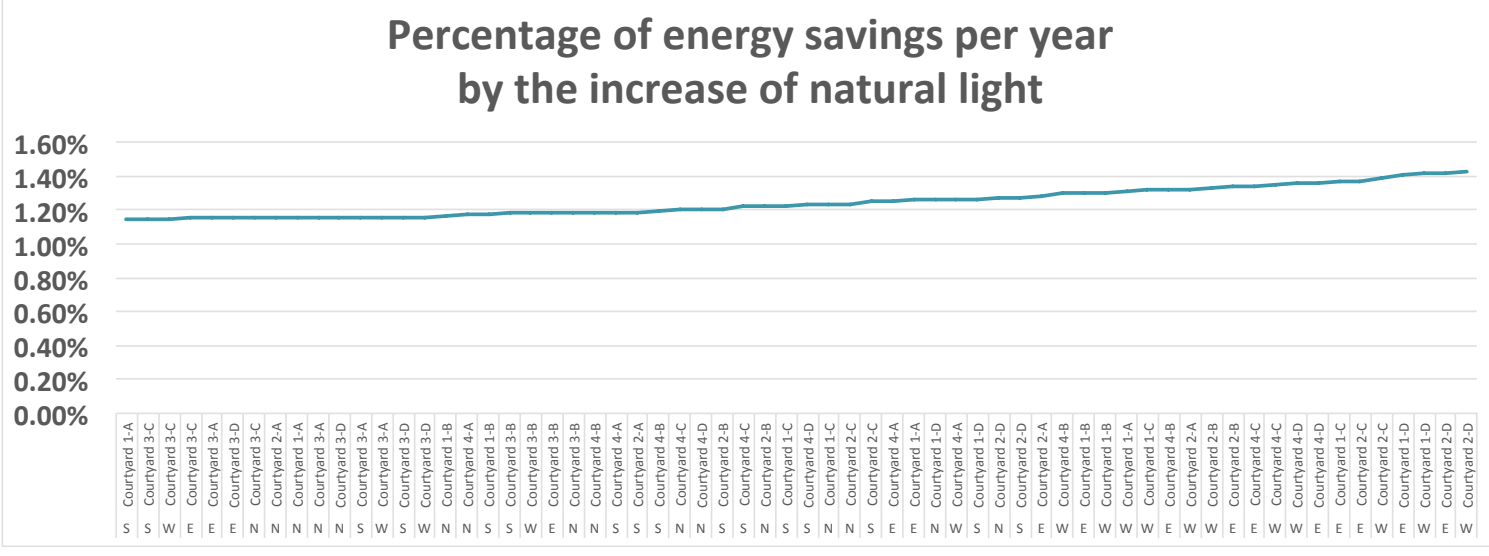

Figure 51: Energy saved by the reduction of energy use in artificial light.

It is important, though, to be aware that the reduced benefits might have been influenced by the high efficiency lights included in the simulation, while in Toronto many households are still using incandescent lights. 
The energy saved from the increase of natural light is not considered in the main analysis as it has shown to have minor influence in the overall energy use of the house.

\subsubsection{Illuminance}

The results regarding the hours of illuminance differ according to the location of the sensors. Throughout all the configurations, the sensors located near the windows (Figure 52) show a low increase in the hours of illuminance. For example, the option with the largest courtyard facing south and with the highest WWR, show very small improvements in the number of daylight hours at both sensors (Figure 53). These results reflect the incidence of the existing front and back windows. While they are very important as a source of natural light near them they also provided limited natural light in the centre of the house.

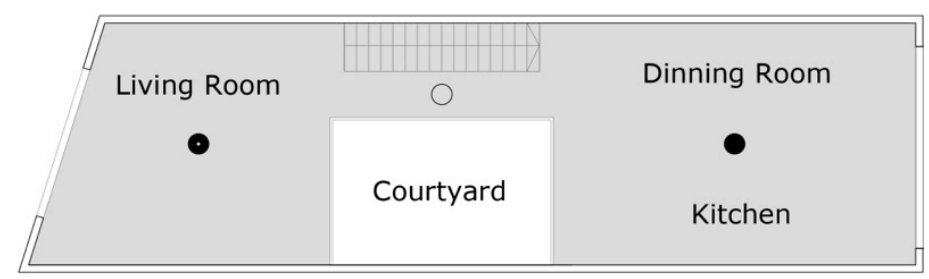

Figure 52: Sensors located near the window 

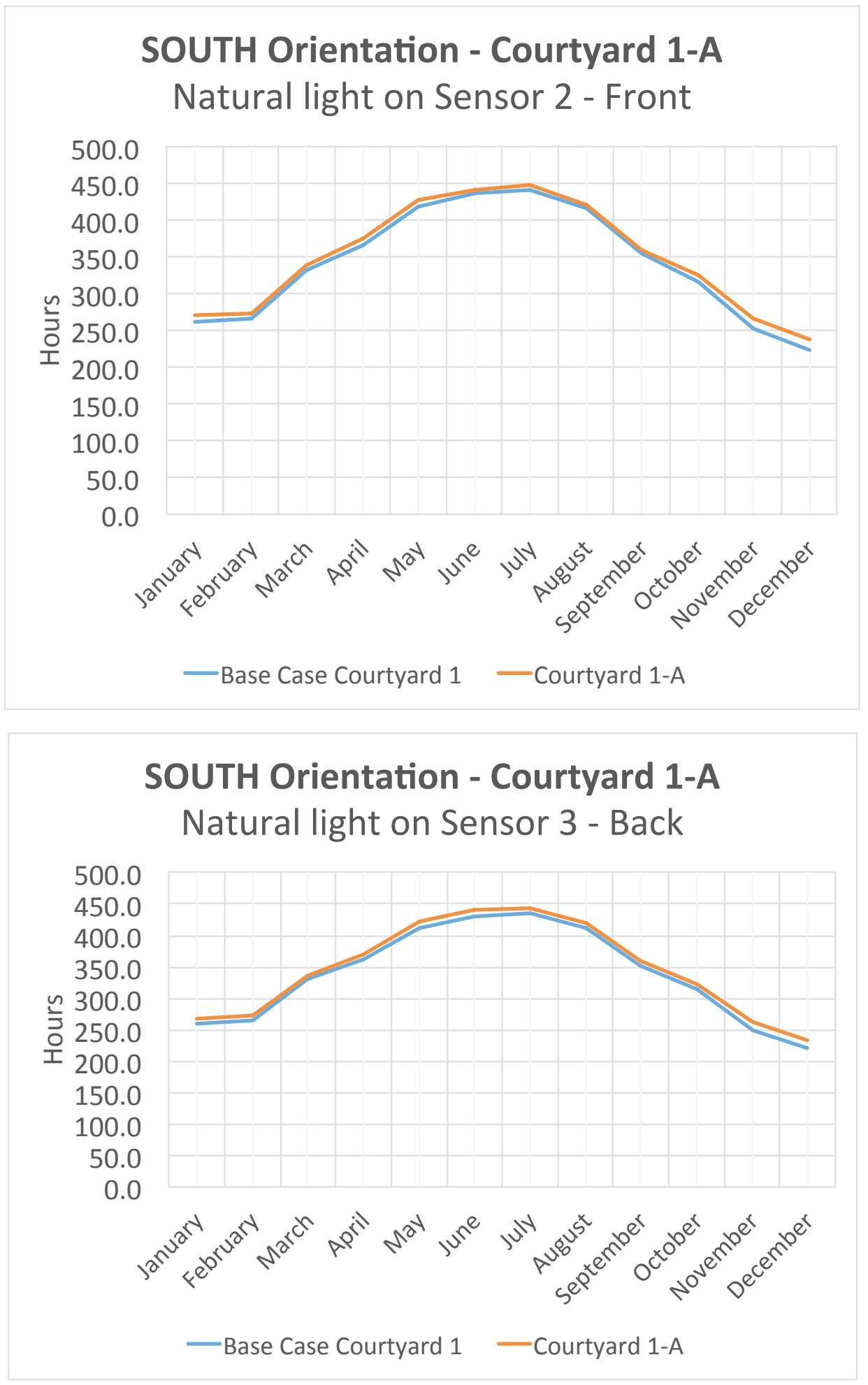

Figure 53: (a) (b) The sensors near the windows do not show much increment in the illuminance hours when they have also the source of the internal courtyard. 

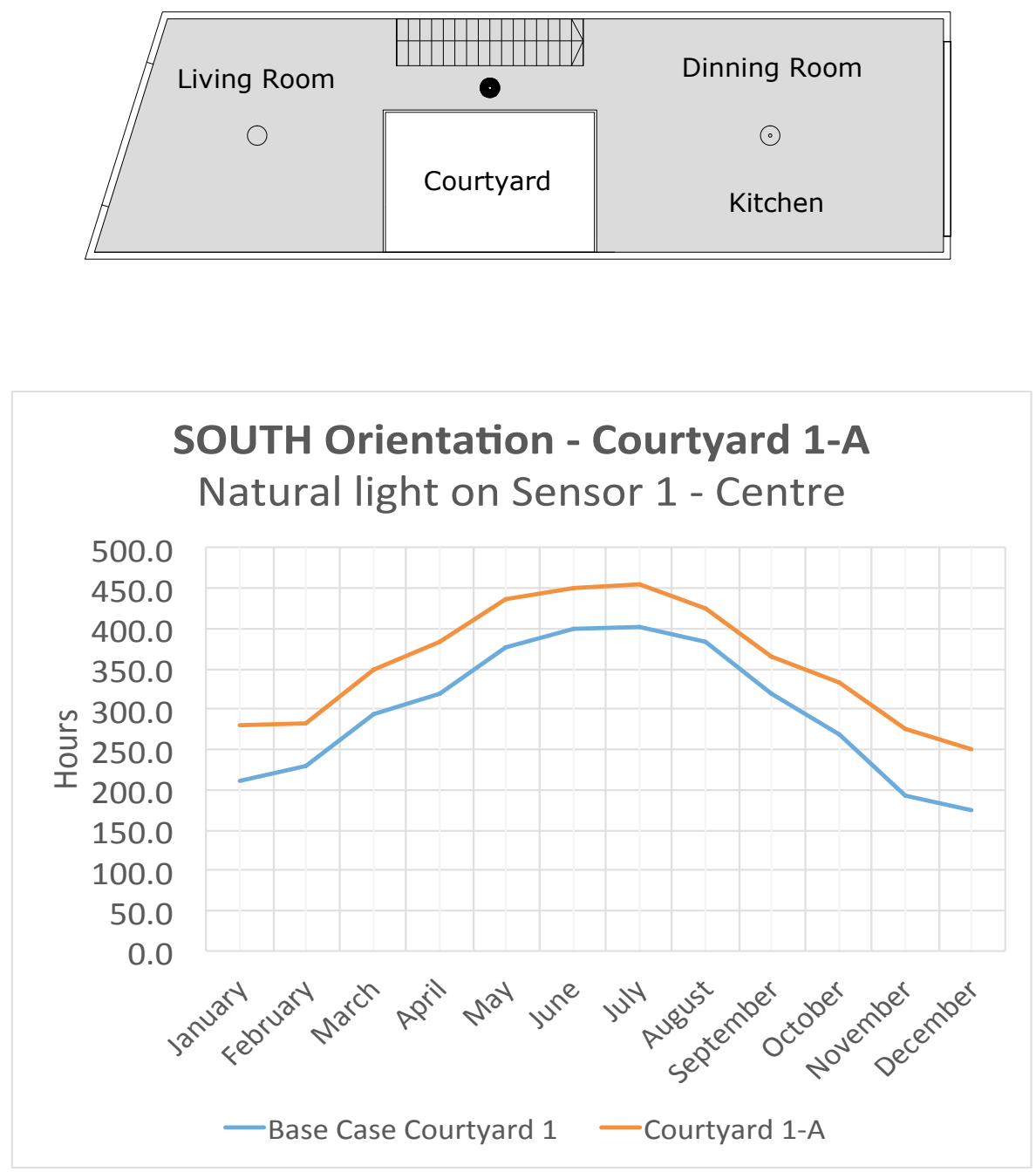

Figure 54: (a) Sensor located in the middle of te floor plan. (b) The sensor in the centre of the house show higher improvements than the ones near the windows.

However, the sensor in the middle of the house provides a significant increase in the hours of daylight (Figure 54) and this pattern is repeated in all cases. For this reason, the analysis will focus on the variations of the hours of illuminance in the middle of the house using only the results from the sensor located in the hallway. 


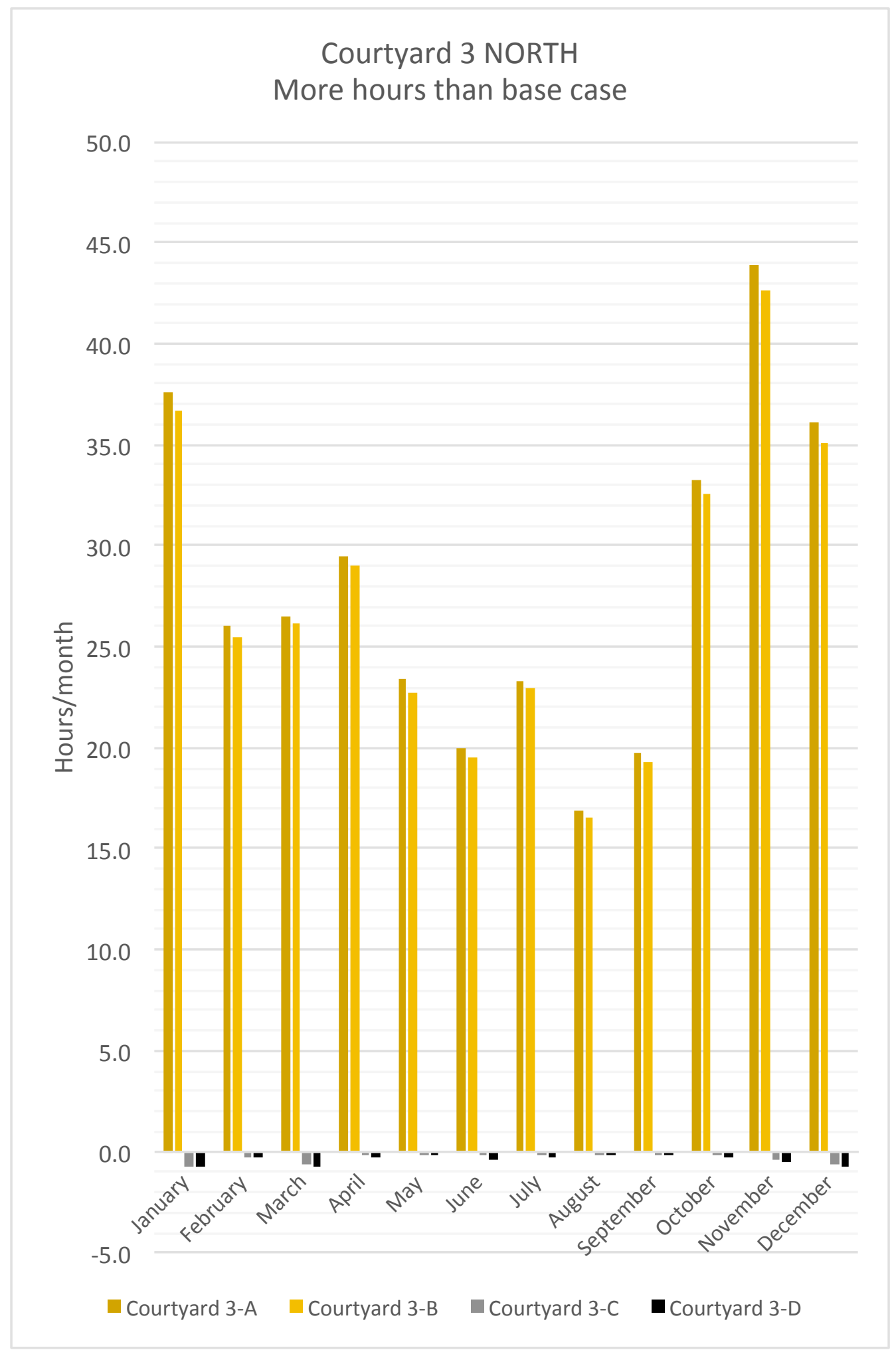

Figure 55: Lower performer, Option 3-B North showing 329 more hours per year or $9 \%$ more than it base case. 3-C and 3-D have less time than it base case. 


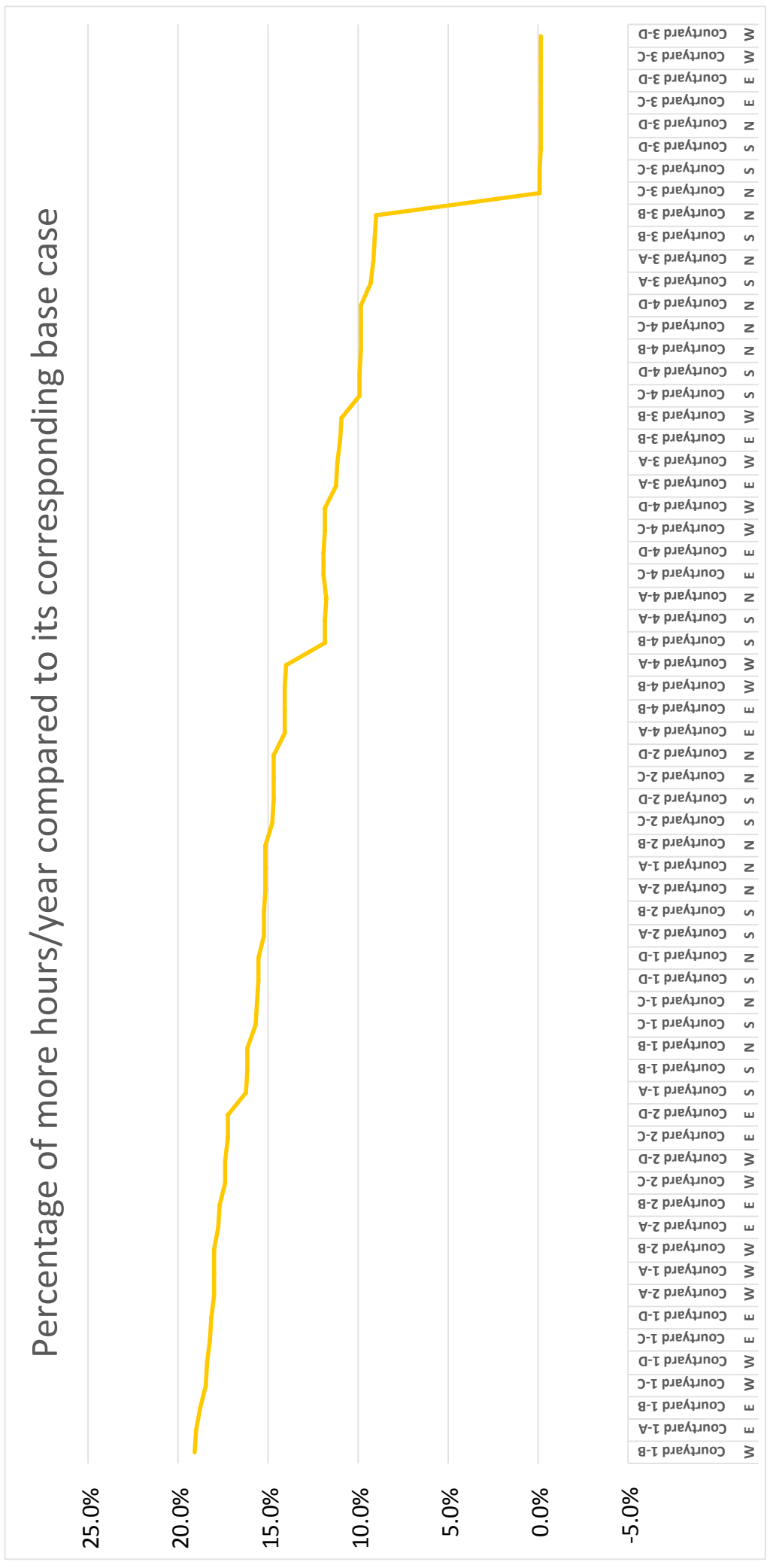

Figure 56: Increase in the amount of hours of natural light compared to each base case. From higher to lower.. 
Eight configurations show negligible increment on the hours of illuminance. Those options are from the configurations of courtyard 3 with a window to wall ratio between $20 \%$ and $42 \%$. Courtyard 3 North, show options C and D with less than one-hour reduction per month (Figure 55). The location of the sensor in those options is far from the light source, where in the other options is near their windows (Figure 57). This results show that rectangular courtyards located parallel to the party wall, should use a window to wall ratios over $55 \%$ to make any improvement in the hours of illuminance.

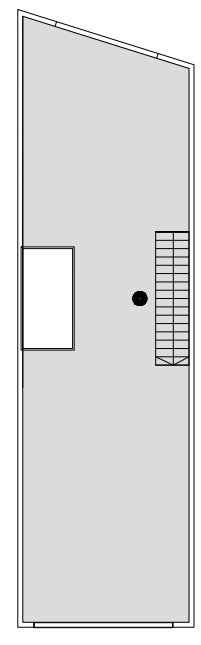

Figure 57: Sensor located far from the light source in courtyards $3-C$ and $3-D$ Fifty-six configurations show improvement in the hours of illuminance ranging between $9 \%$ and $20 \%$ more hours per year compared to their base cases (Figure 56). Those increments represent between 329 to 714 more hours of light per year in the centre of the row house. Considering the yearly outcomes, the results for these options show an average increase of hours between 54 to 1 hour and 54 minutes per day.

An unexpected outcome is found when we analyze that information on a monthly basis. The distribution of the increments is not equal and the general trend shows that the months with shorter days have a higher increment of hours compared to months where the days are longer. For example, in the case of the best performer 1-A West, in November it gets 83 more hours of light, in December 72 and in January 65, while the increment of June is just 47 hours, July 50 and August 41 (Figure 58). 


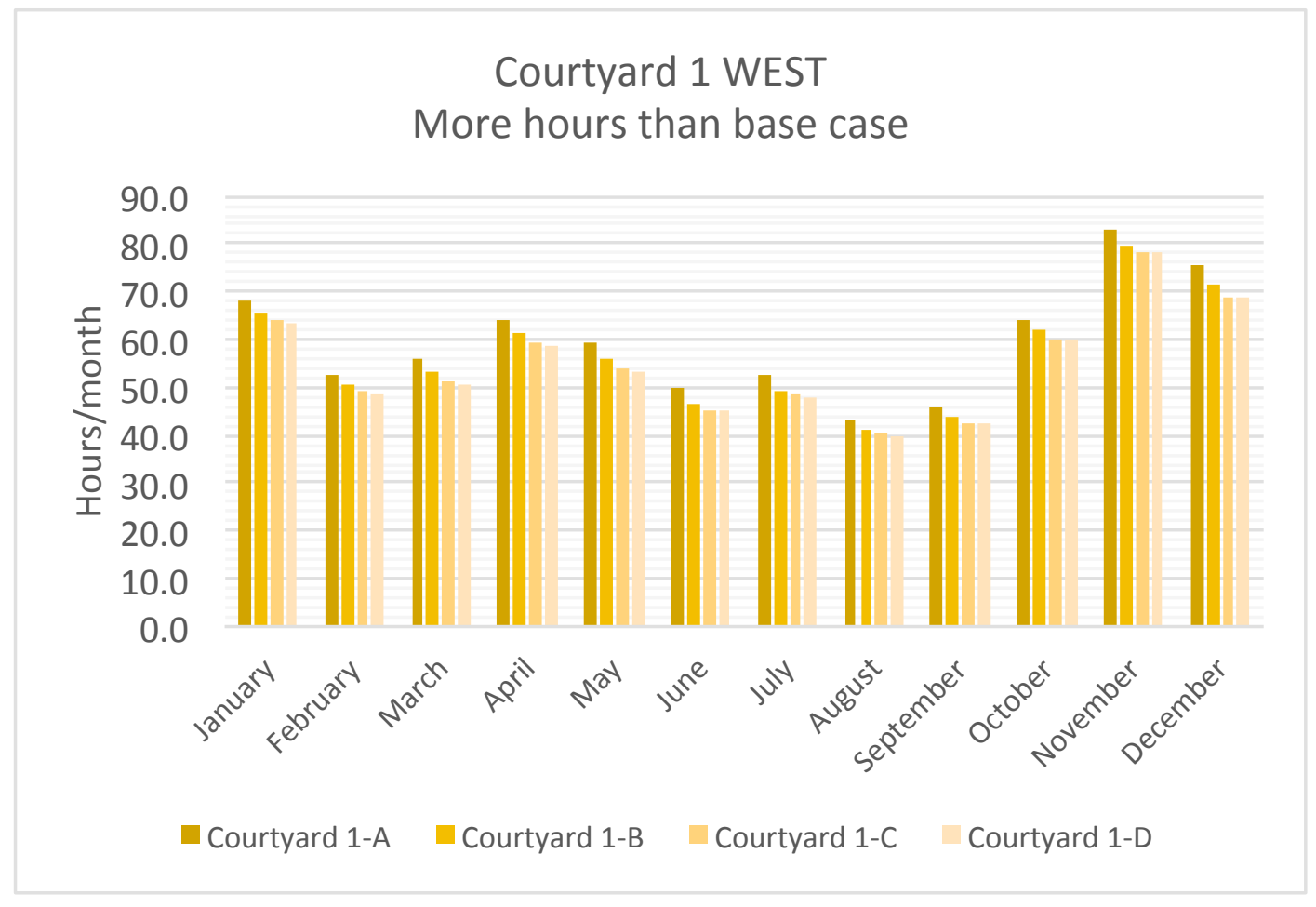

Figure 58: Best performer in Illuminance: option 1-A West showing 714 more hours per year or $20 \%$ more than the base case.

These findings are critical to the research questions as they show that the inclusion of an internal courtyard not only increases the hours of illuminance in the house, but that those increases are higher in the months when the sun and light is more sought. The implications of such improvements are important in the winter days, when the indoor activities are predominant, and could lead to health improvements for people who are recovering from an illness as well as for those suffering depression or other mental illness. Using the sunset and sunrise times in specific days of the year (National Research Council Canada, 2014) and analyzing the time of those days with hours of illuminance above 100 lux explains better the implications throughout the day (Table 9). 
Table 9: Best performer 1-A. Sunrise and sunset time compared to the time of the day when the sensors reach 100 lux. Between brackets is the total amount of hours that the sensors reach 100 lux.

\begin{tabular}{|c|c|c|c|}
\hline & Sunset/Sunrise & $\begin{array}{l}\text { Sensor reaching } 100 \text { lux } \\
\text { in the West base case } \\
\text { (No courtyard) }\end{array}$ & $\begin{array}{l}\text { Sensor reaching } \\
100 \text { lux in } \\
\text { Courtyard 1-A West }\end{array}$ \\
\hline June & $4: 35 \mathrm{hs} / 20: 01 \mathrm{hs}$ & $5: 38 \mathrm{hs} / 19: 00 \mathrm{hs}$ & $4.51 \mathrm{hs} / 19: 45 \mathrm{hs}$ \\
\hline 15th & (Total 15.44hrs) & (Total13.33hs) & (Total 14.9hs) \\
\hline September & $5: 57 \mathrm{hs} / 18: 28 \mathrm{hs}$ & $6: 46 \mathrm{hs} / 17: 26 \mathrm{hs}$ & $6: 02 \mathrm{hs} / 18.11 \mathrm{hs}$ \\
\hline 15 th & (Total 12.52hs) & (Total10.66hs) & (Total12.13hs) \\
\hline December & $7: 44 \mathrm{hs} / 16: 41 \mathrm{hs}$ & 9:02hs/15:02hs & $8: 15 \mathrm{hs} / 16.12 \mathrm{hs}$ \\
\hline 15 th & (Total 8.94hs) & (Total 5.64hs) & (Total7.93hs) \\
\hline
\end{tabular}

Considering the best performer 1-A West, in the shortest day of the year, the hours of illuminance will reach 100 lux at 8.15AM instead of 9.02AM and it will get dark at 4.12PM instead of 3.02PM. Improvements in the hours of illuminance can be found also in the lowest performers. Option 3-A North (Figure 53) show similar improvements than the options with larger courtyards. This option shows November getting 44 more hours than the base case, December 36 and January 38, while June 20, July 23 and August 17 more hours. The inclusion of an internal courtyard improves significantly the hours of illuminance in the middle of the house, with major implications in a time of the year with long nights and short days. In a city like Toronto, during days with temperatures below freezing the activities on the interior could be extended significantly without using artificial light. The activities inside the house could be extended more than 1 hour in the afternoon of the shortest days of the year. The mornings will get light sooner and the evenings will become darker later. 


\subsubsection{Window to wall ratio}

For some situations, windows are considered a weak point regarding energy performance but an important feature regarding the illuminance inside the house. One of the research questions of this study looks for an optimal balance between these two parameters.

The results show that the options with the larger courtyards have the shortest ranges of increase in the illuminance hours. They also show that there is a steep difference in courtyard 3 (Figure 59).

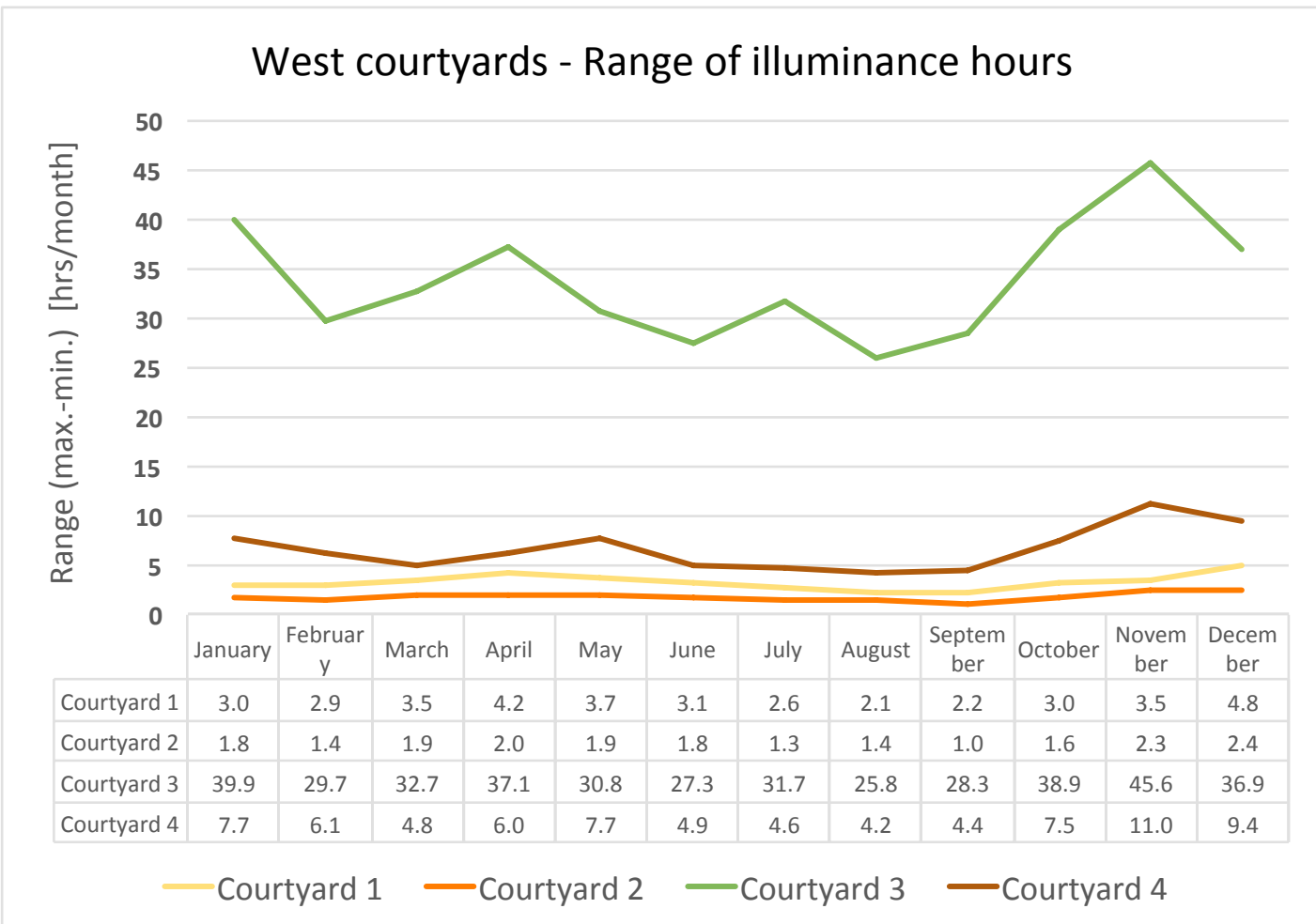

Figure 59: Difference in the hour's range of illuminance between the highest and the lowest WWR for each courtyard on each month

The pattern is found in all the orientations, with ranges below 5 hours per month for the courtyards 1 and 2 and maximum ranges of 10 hours per month for the courtyard 4. 
These results show that for the larger courtyards a higher WWR is not necessary for achieving the daylight target of 100 lux. Only in courtyard 3 there is a significant difference of over 30 hours per month when a higher WWR is chosen. Courtyard 3 shows that the options with lower WWR are not worth pursuing, as there are not improvements in the hours of illuminance at any orientation. As mentioned before, the results for courtyard 3 only show improvements when using the higher WWR (Figure 55).

\subsubsection{Total energy use of the row houses with courtyards}

The energy performance of each option is compared to their base case resulting in a percentage value of energy use increase for heating and cooling. The results show that the row houses with internal courtyards use between 13\% and 36\% more energy that their base cases (Figure 62). When considering the cost implications on the energy bills according to the 2014 energy costs in Toronto for residential properties, the annual cost calculated for the row houses with courtyards ranges from $\$ 1905$ to $\$ 2351$ (Figure 66). Percentage wise, if we compare them with their base cases the cost increases range between $7 \%$ and $22 \%$. The heating dominated climate and the low cost of the natural gas show that even when the maximum increase of energy use is of $36 \%$, the maximum increase in cost is only 22\% (Appendix F).

Most of the smaller sized courtyards have a smaller energy increase, while the larger courtyards have the bigger energy penalty. The window to wall ratio (WWR) also shows an influence on the distribution of the results. The lower WWR courtyards also tend to have a smaller increase in energy use.

As each option is compared to it base case, the order generated from lower to higher percentage of energy use does not correlate equally to a scale ordered 
according to the total energy use. But if the options are reorganized according to the total energy use, the smaller courtyards still stay within the lower energy use range, and the same happens to the ones with lower WWR (Figure 65). On the other hand, as was noted before, these small courtyard configurations result in lower hours of illuminance.

To find an optimal configuration it is needed to combine the energy performance and daylight values, but the best results from one outcome has shown not to be the best for the other. For example, if we analyze the group of the best performer regarding illuminance the increment of light shows that the best case for the courtyards 1 West improves 20\% in hours of light but increases $31.2 \%$ in energy use. The results also show that while there are minor differences in the hours of illuminance within the group 1 West, the energy performance show significant reductions (Figure 60).

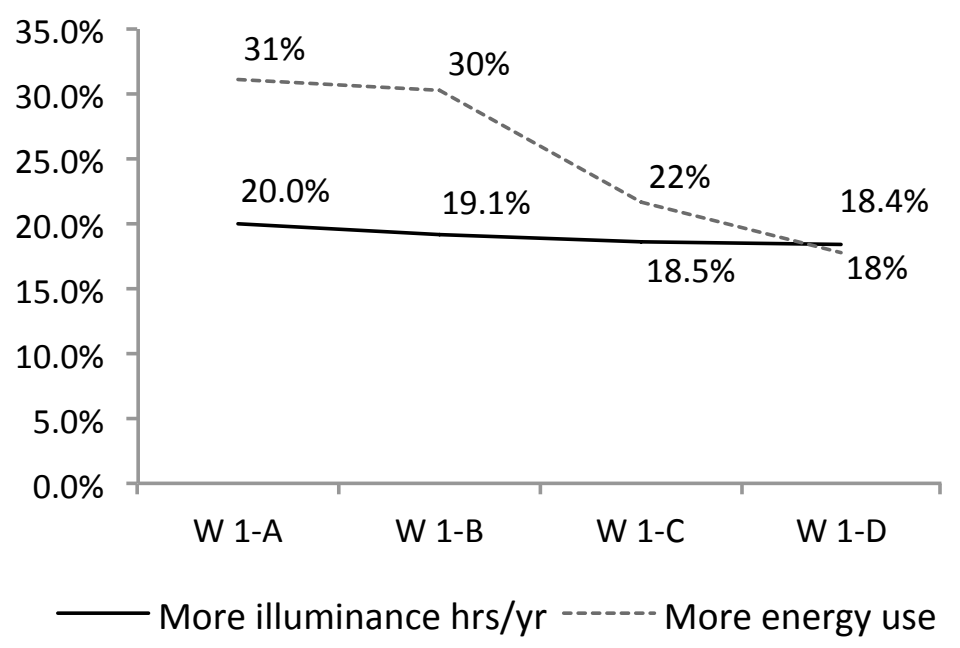

Figure 60: Hours of illuminance vs. energy use for courtyards 1 West 


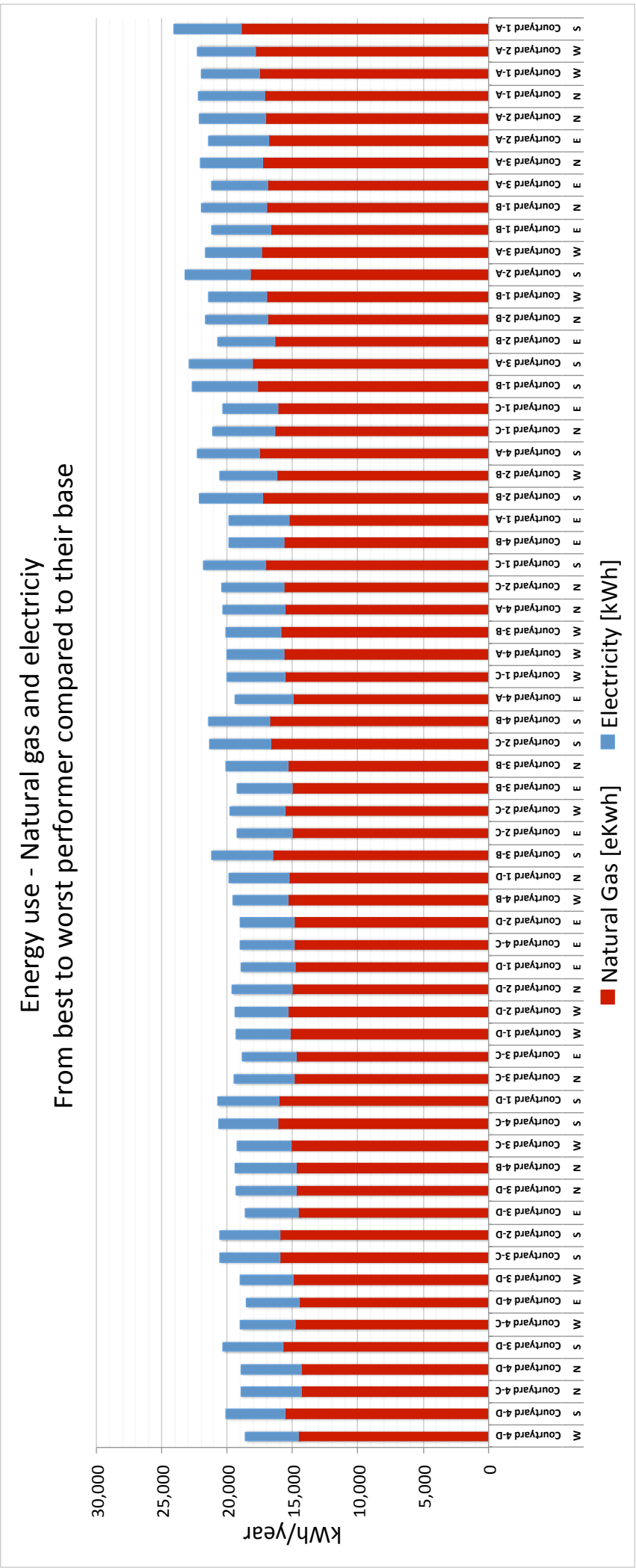

Figure 61: Total energy use for heating and cooling. Ordered from best to worst performer compared to their base cases 


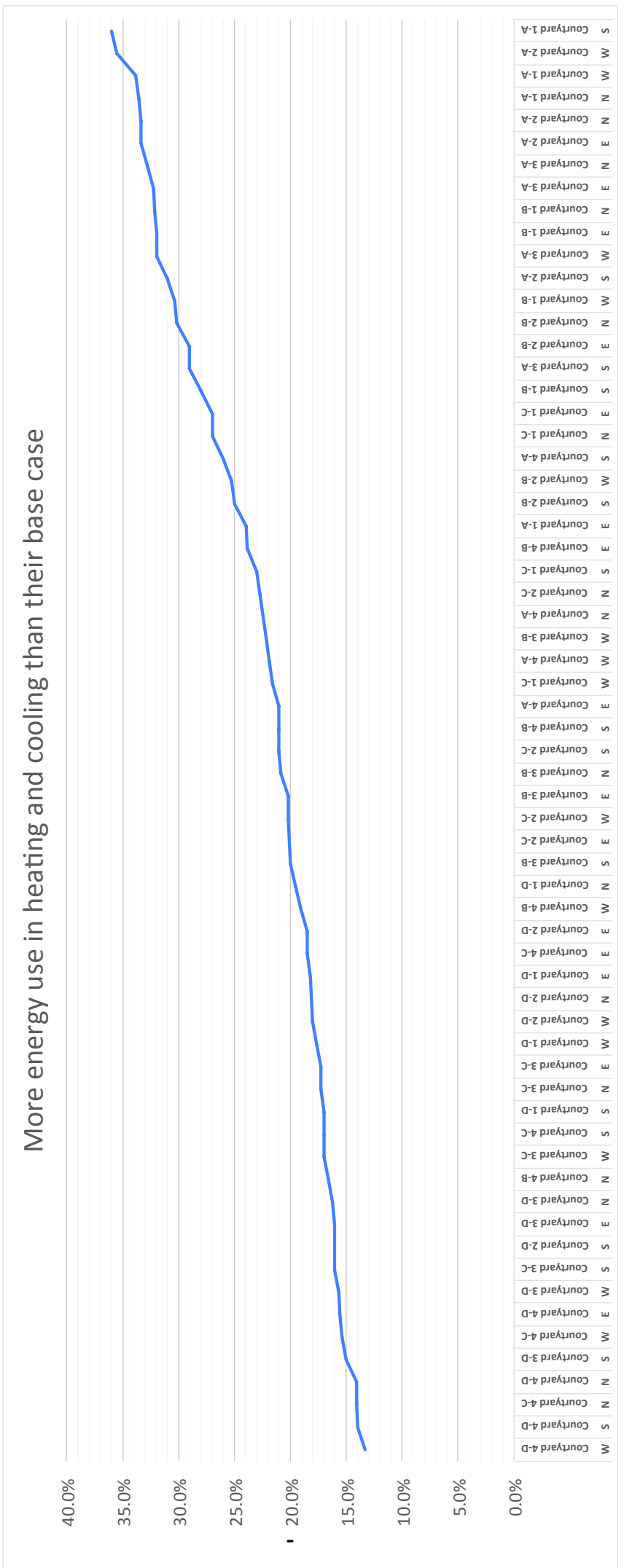

Figure 62: Total energy use for heating and cooling compared to their base case 


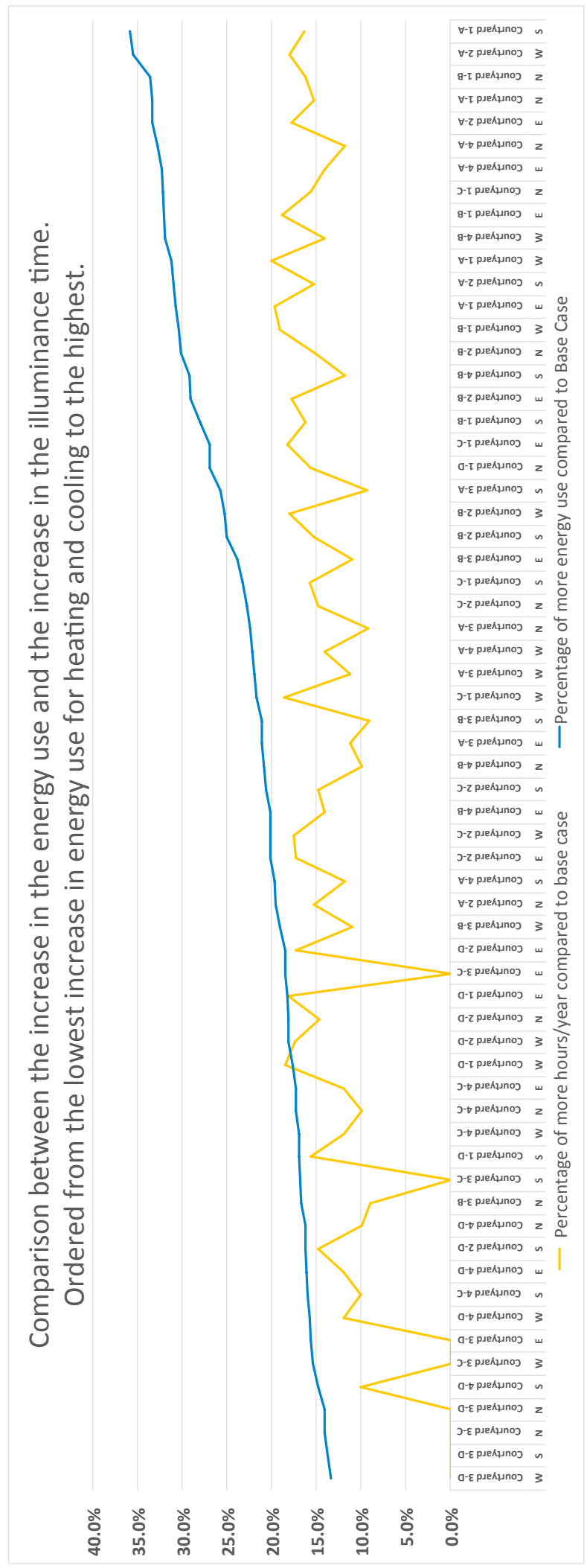

Figure 63: Comparison between the increase in energy use and the increase in the illuminance time. Ordered from lower to higher energy use for heating and cooling. 


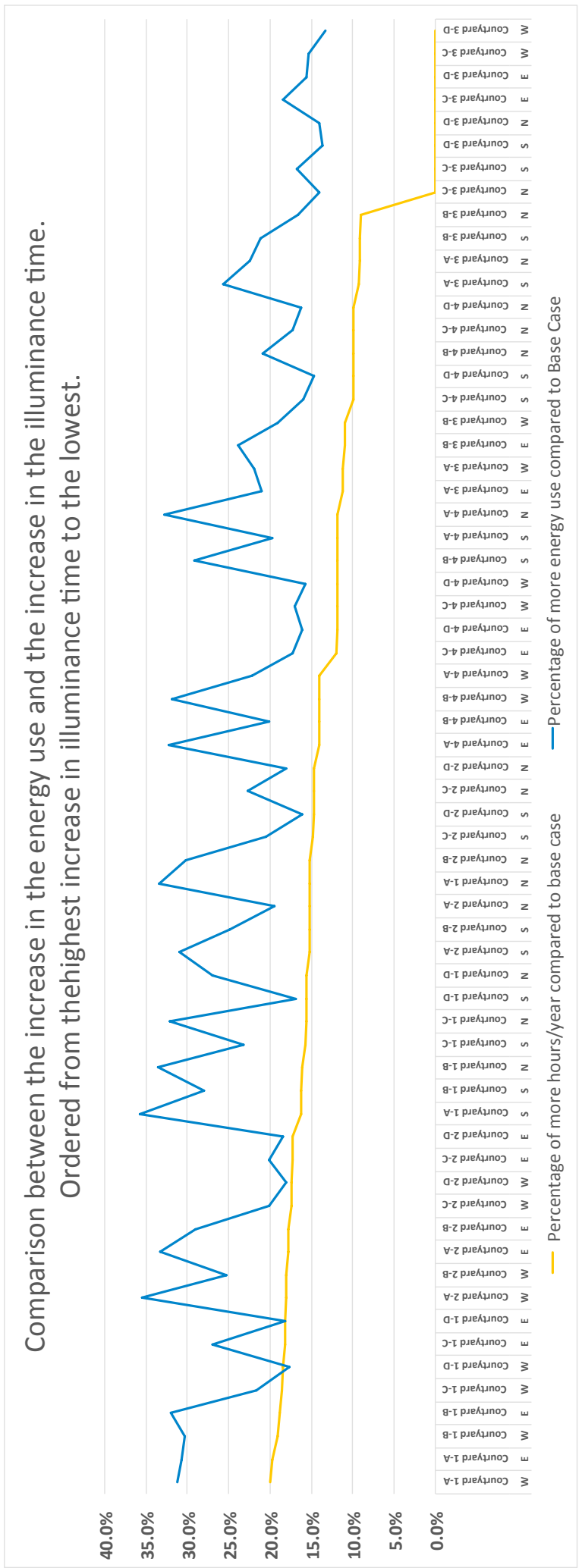

Figure 64: Comparison between the increase in illuminance time and energy use. Ordered from higher illuminance increase to lower. 


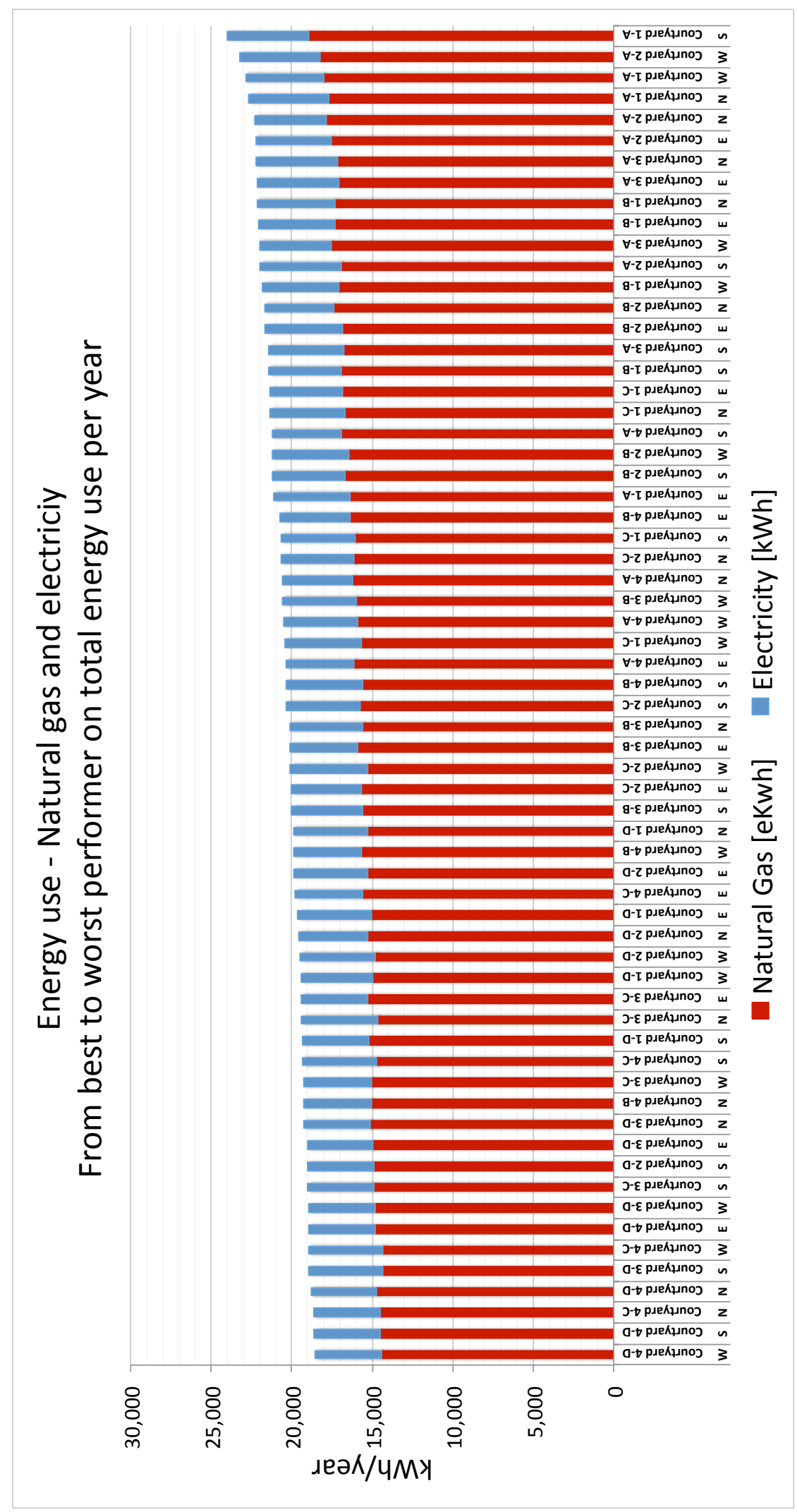

Figure 65: Energy use for heating and cooling offered from lower to higher 


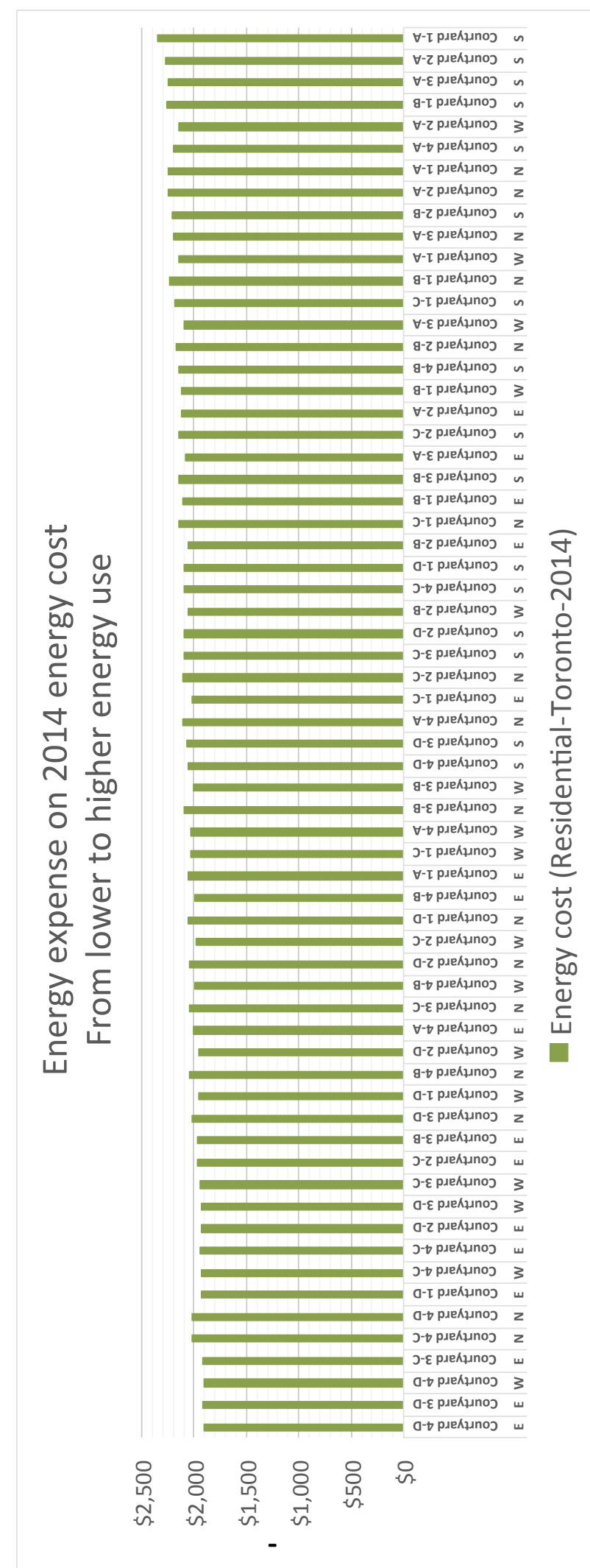

Figure 66: Utility bills cost according to 2014 values. From lower to higher energy use for heating and cooling. 


\subsection{Priority scales}

Defining the optimal configuration of an internal courtyard is directly related to the importance that each parameter is given. As seen in the results, the options performing better in energy are not the ones performing better in hours of illuminance. To find optimal configurations a set of 6 priorities is established according to the value that each parameter is given. The outputs are organized and selected from a first priority parameter. Within that selected group a second priority parameter is established for the next selection, and within the selected ones a third priority parameter is applied.

\section{Priority scale 1}

1. ILLUMINANCE best 8

2. NATURAL GAS best 4

3. ELECTRICITY best 2

\section{Priority scale 2}

1. ILLUMINANCE best 8

2. ELECTRICITY best 4

3. NATURAL GAS best 2

\section{Priority scale 3}

1. NATURAL GAS best 8

2. ELECTRICITY best 4

3. ILLUMINANCE best 2

\section{Priority scale 4}

1. NATURAL GAS best 8

2. ILLUMINANCE best 4

3. ELECTRICITY best 2

\section{Priority scale 5}

1. ELECTRICITY best 8

2. NATURAL GAS best 4

3. ILLUMINANCE best 2

\section{Priority scale 6}

1. ELECTRICITY best 8

2. ILLUMINANCE best 4

3. NATURAL GAS best 2

From the first priority the best eight options are selected. Within those eight options, the second priority is applied and the best four are selected. Among those four, the third priority is applied to get the best performers in that scale. It is important to clarify that the only system in the house that uses natural gas is 
the heating system, while the outcome of the electrical use includes all the appliances, domestic hot water lights and fans in the house. As mentioned in the energy use section 5.3.1, the results also show that he influence of the internal courtyard in the reduction of electrical use for lights is minimal (Figure 51) and thus it could be considered that the electrical use variance will be related mostly to the increment of air conditioning system.

Four courtyard options rank within most of the priority scales as the best and second best (Figure 66). As expected from the previous results, all of them have the lowest window to wall ratios and courtyard 3 is not included.

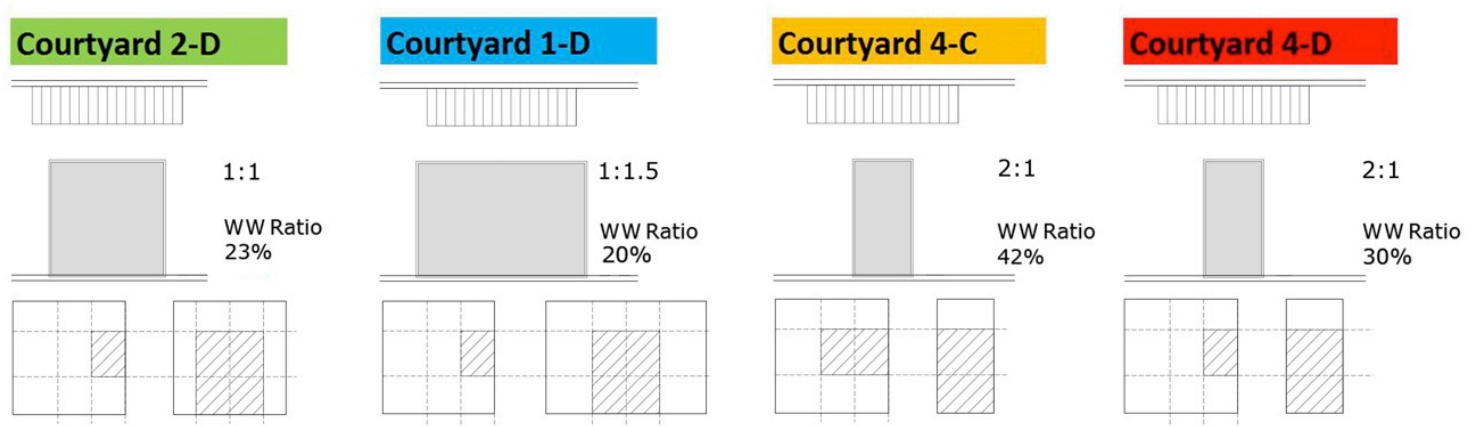

Figure 66: Best results in 22 of the 24 priority scales. 


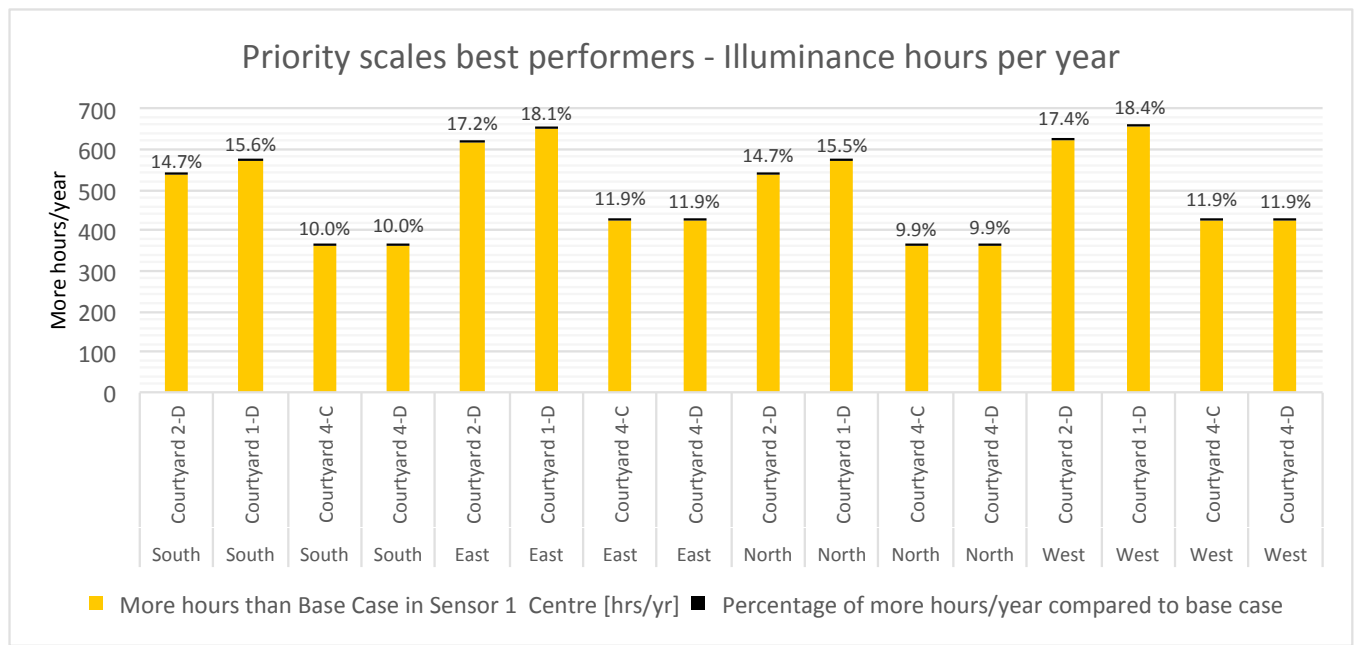

Figure 67: Hours of illuminance for the best results on priority scales

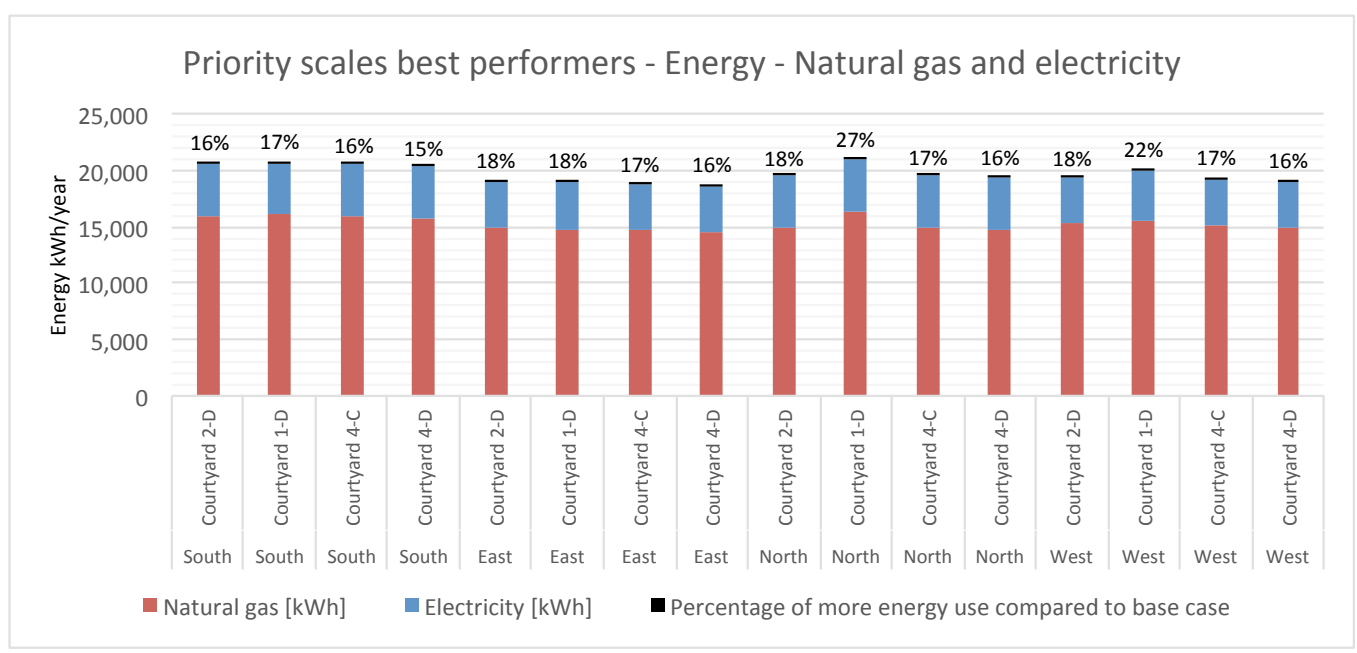

Figure 68: Energy use of the best results on priority scales

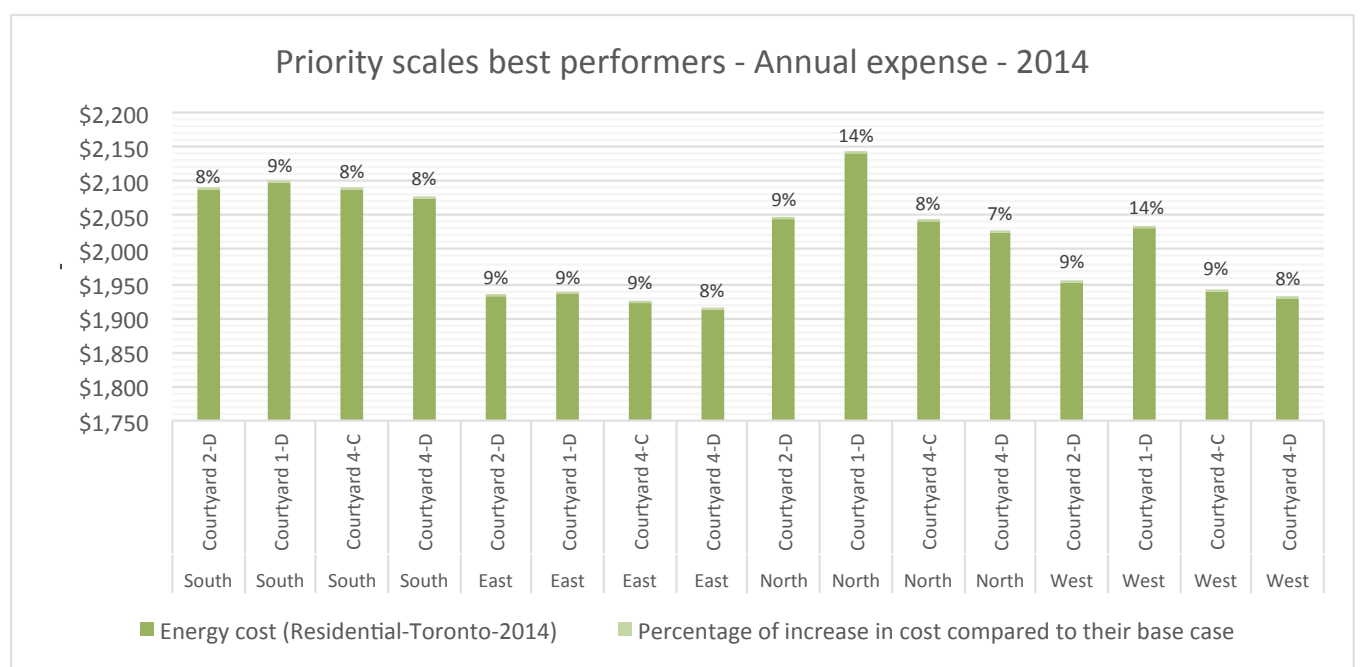

Figure 69: 2014 Utility costs for the best results on priority scales 
Considering all the orientations, the courtyards 2-D and 1-D are the ones that appear the most and have the best outcomes in most of the cases.

Courtyard 1-D slightly better in the hours of illuminance (Figure 67) and courtyard 2-D in the energy performance. Comparing all the orientations, the energy use show a similar result, with most of them needing between $16 \%$ and $18 \%$ more energy use than their base cases (Figure 68). Only the north oriented courtyard 1-D shows a significant higher energy use over $27 \%$ of it base case.

If we tie the illuminance increase and the energy use, the best performers are 2D and 1-D oriented to the East and West. Both have the highest illuminance increases and the lower energy use compared all the orientations of those courtyards.

An unexpected result shows that the south oriented ones show an overall higher energy use as well as overall higher utility costs (based on 2014 values) (Figure 69), while they are not the best performers on the hours of illuminance either. The South and North orientations should have an even distributed increase in the hours of illuminance early and later in the day but further analysis should be done to understand how is distributed that increment in the East and West orientations.

The full lists of best results organized for each orientation can be found in Table 10 to Table 13. 
Table 10: Priority scale results for the South orientation

SOUTH Orientation

\begin{tabular}{|c|c|c|c|c|c|c|}
\hline Priority scale 1 & & & 1st & 2nd & $3 \mathrm{rd}$ & 4th \\
\hline Wluminance best 8 & Natural gas best 4 & Electricity best 2 & Courtyard 2-D & Courtyard 1-D & Courtyard 2-C & Courtyard 1-C \\
\hline Priority scale 2 & & & 1st & 2nd & 3 rd & 4th \\
\hline Illuminance best 8 & Electricity best 4 & Natural gas Best 2 & Courtyard 2-D & Courtyard 1-D & Courtyard 2-C & Courtyard 1-C \\
\hline Priority scale 3 & & & 1st & 2nd & 3 rd & 4th \\
\hline Natural gas best 8 & Electricity best 4 & Illuminance best 2 & Courtyard 2-D & Courtyard 4-C & Courtyard 4-D & Courtyard 3-D \\
\hline Priority scale 4 & & & 1st & 2nd & 3 rd & 4th \\
\hline Natural gas best 8 & Illuminance best 4 & Electricity best 2 & Courtyard 4-C & Courtyard 2-D & Courtyard 1-D & Courtyard 2-C \\
\hline Priority scale 5 & & & 1st & 2nd & $3 r d$ & 4th \\
\hline Electricity best 8 & Natural gas best 4 & Illuminance best 2 & Courtyard 2-D & Courtyard 4-D & Courtyard 3-C & Courtyard 3-D \\
\hline Priority scale 6 & & & 1st & 2nd & $3 r d$ & 4th \\
\hline Electricity best 8 & Illuminance best 4 & Natural gas best 2 & Courtyard 2-D & Courtyard 1-D & Courtyard 2-C & Courtyard 4-B \\
\hline
\end{tabular}

Table 11: Priority scale results for the East orientation.

EAST Orientation

\begin{tabular}{|c|c|c|c|c|c|c|}
\hline \multirow{2}{*}{\begin{tabular}{|l} 
Priority scale 1 \\
Illuminance best 8
\end{tabular}} & \multirow[b]{2}{*}{ Natural gas best 4} & \multirow[b]{2}{*}{ Electricity best 2} & \multirow{2}{*}{\begin{tabular}{|l} 
1st \\
Courtyard 2-D
\end{tabular}} & \multirow{2}{*}{$\begin{array}{l}\text { 2nd } \\
\text { Courtyard 1-D }\end{array}$} & \multirow{2}{*}{$\begin{array}{l}\text { 3rd } \\
\text { Courtyard 2-C }\end{array}$} & \multirow{2}{*}{$\begin{array}{l}\text { 4th } \\
\text { Courtyard 1-A }\end{array}$} \\
\hline & & & & & & \\
\hline Priority scale 2 & & & 1st & 2nd & 3 rd & 4th \\
\hline Illuminance best 8 & Electricity best 4 & Natural gas Best 2 & Courtyard 1-D & Courtyard 2-D & Courtyard 2-C & Courtyard 1-C \\
\hline Priority scale 3 & & & 1st & 2nd & 3 rd & 4th \\
\hline Natural gas best 8 & Electricity best 4 & Illuminance best 2 & Courtyard 2-D & Courtyard 4-D & Courtyard 3-C & Courtyard 3-D \\
\hline Priority scale 4 & & & 1st & 2nd & 3 rd & 4th \\
\hline Natural gas best 8 & Illuminance best 4 & Electricity best 2 & Courtyard 2-D & Courtyard 1-D & Courtyard 2-C & Courtyard 4-A \\
\hline Priority scale 5 & & & 1st & 2nd & $3 r d$ & 4th \\
\hline Electricity best 8 & Natural gas best 4 & Illuminance best 2 & Courtyard 1-D & Courtyard 4-D & Courtyard 3-C & Courtyard 3-D \\
\hline Priority scale 6 & & & 1st & 2nd & 3 rd & 4th \\
\hline Electricity best 8 & Illuminance best 4 & Natural gas best 2 & Courtyard 1-D & Courtyard 4-C & Courtyard 2-D & Courtyard 4-B \\
\hline
\end{tabular}

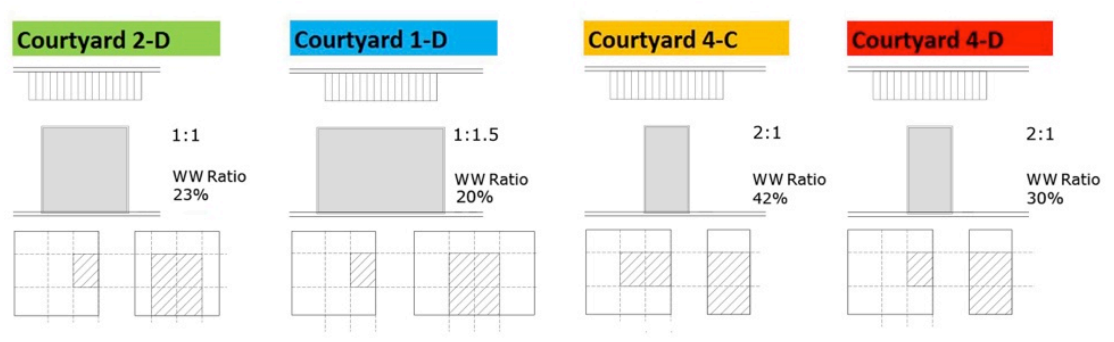


Table 12: Priority scale results for the North orientation.

NORTH Orientation

\begin{tabular}{|c|c|c|c|c|c|c|}
\hline \multirow{2}{*}{$\begin{array}{l}\text { Priority scale } 1 \\
\text { Illuminance best } 8\end{array}$} & \multirow[b]{2}{*}{ Natural gas best 4} & \multirow[b]{2}{*}{ Electricity best 2} & \multirow{2}{*}{$\begin{array}{l}\text { 1st } \\
\text { Courtyard 2-D }\end{array}$} & \multirow{2}{*}{$\begin{array}{l}\text { 2nd } \\
\text { Courtyard 1-D }\end{array}$} & \multirow{2}{*}{$\begin{array}{l}\text { 3rd } \\
\text { Courtyard 2-C }\end{array}$} & \multirow{2}{*}{$\begin{array}{l}\text { 4th } \\
\text { Courtyard 1-C }\end{array}$} \\
\hline & & & & & & \\
\hline Priority scale 2 & & & 1st & 2nd & $3 r d$ & 4 th \\
\hline Illuminance best 8 & Electricity best 4 & Natural gas Best 2 & Courtyard 2-D & Courtyard 1-D & Courtyard 2-C & Courtyard 1-C \\
\hline Priority scale 3 & & & 1st & 2nd & $3 r d$ & 4 th \\
\hline Natural gas best 8 & Electricity best 4 & Illuminance best 2 & Courtyard 1-D & Courtyard 1-D & Courtyard 2-C & Courtyard 1-C \\
\hline Priority scale 4 & & & 1st & 2nd & 3 rd & 4 th \\
\hline Natural gas best 8 & Illuminance best 4 & Electricity best 2 & Courtyard 2-D & Courtyard 1-D & Courtyard 4-C & Courtyard 4-B \\
\hline Priority scale 5 & & & 1st & 2nd & 3 rd & 4 th \\
\hline Electricity best 8 & Natural gas best 4 & Illuminance best 2 & Courtyard 4-B & Courtyard 4-C & Courtyard 4-D & Courtyard 3-D \\
\hline Priority scale 6 & & & 1st & 2nd & $3 r d$ & 4 th \\
\hline Electricity best 8 & Illuminance best 4 & Natural gas best 2 & Courtyard 4-B & Courtyard 2-D & Courtyard 1-D & Courtyard 2-C \\
\hline
\end{tabular}

Table 13: Priority scale results for the West orientation.

WEST Orientation

\begin{tabular}{|lllllll|}
\hline $\begin{array}{l}\text { Priority scale 1 } \\
\text { Illuminance best 8 }\end{array}$ & Natural gas best 4 & Electricity best 2 & 1st & 2nd & 3rd & 4th \\
\hline & & & & & & \\
\hline
\end{tabular}

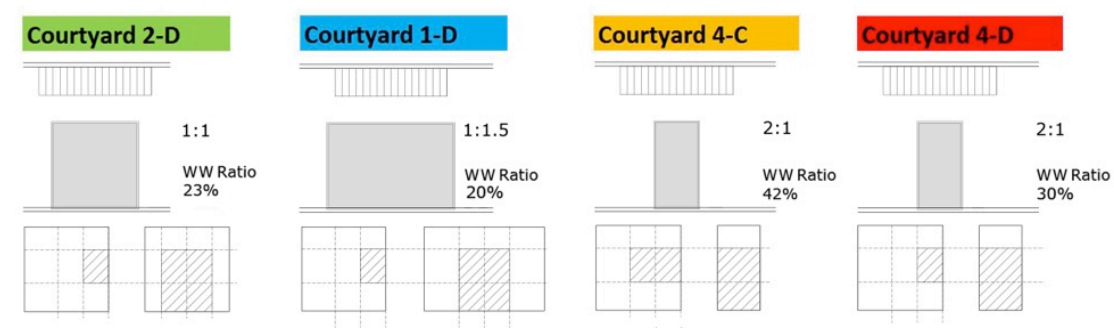




\subsection{Design guidelines}

All the information gathered in the simulations has been organized in four charts where the outcomes can be easily found and compared (Figure 70). The information on the charts includes the total yearly hours of illuminance above 100 lux in the centre of the house in the yellow boxes, and it is compared to the base case showing the increased percentage on the right side. It also shows the total energy use of natural gas in light red and electricity in light blue, and compares the total increase of energy use to the base case. On the far right the window to wall ratio information is found. These charts are organized as design guidelines to help designers navigate the options fluently within the courtyard alternatives. The charts also highlight the best performing options according to the priority scale results (Table 14 to Table 17). The options highlighted in strong red, green, blue and yellow show the best performers combining all the variables.

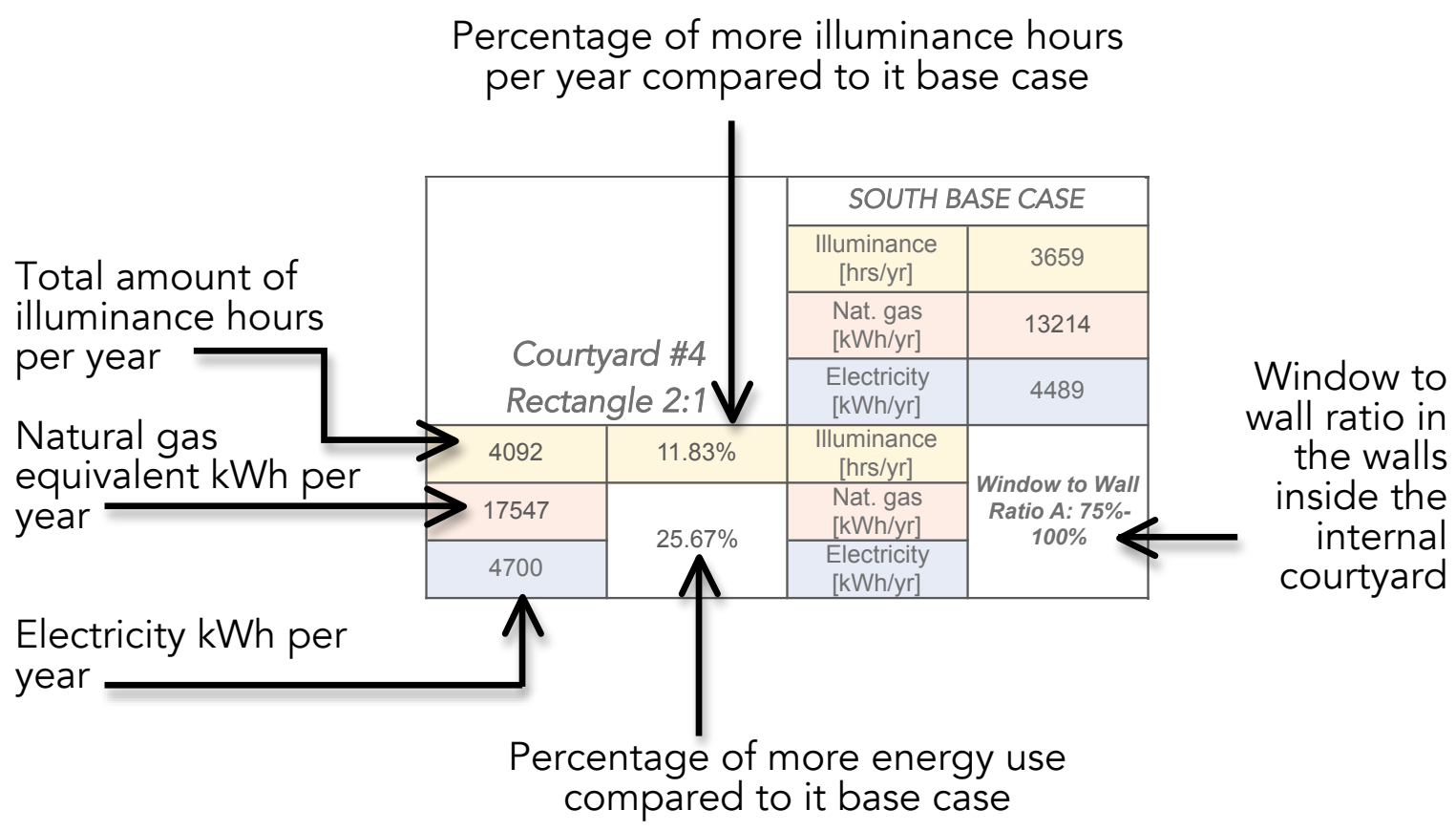

Figure 70: Example of the information to be found in the chart. 
Table 14: South orientation information chart.

\begin{tabular}{|c|c|c|c|c|c|c|c|c|c|}
\hline \multicolumn{10}{|c|}{ SOUTH Orientation chart } \\
\hline \multirow{4}{*}{\multicolumn{2}{|c|}{$\begin{array}{c}\text { Courtyard \#1 } \\
\text { Rectangle 1:1.5 }\end{array}$}} & & & \multirow{4}{*}{\multicolumn{2}{|c|}{$\begin{array}{r}\text { Courtyard \#3 } \\
\text { Rectangle 1:2 }\end{array}$}} & \multirow{4}{*}{\multicolumn{2}{|c|}{$\begin{array}{l}\text { Courtyard \#4 } \\
\text { Rectangle 2:1 }\end{array}$}} & \multicolumn{2}{|c|}{ SOUTH BASE CASE } \\
\hline & & & & & & & & $\begin{array}{c}\text { Illuminance } \\
\text { [hrs/yr] }\end{array}$ & 3659 \\
\hline & & \multirow{2}{*}{$\begin{array}{ll}\text { Courtyard } & \# 2 \\
\text { Squared } & 1: 1\end{array}$} & & & & & & $\begin{array}{l}\text { Nat. gas } \\
{[\mathrm{kWh} / \mathrm{yr}]}\end{array}$ & 13214 \\
\hline & & & & & & & & $\begin{array}{l}\text { Electricity } \\
{[\mathrm{kWh} / \mathrm{yr}]}\end{array}$ & 4489 \\
\hline 4254 & $16.27 \%$ & 4218 & $15.26 \%$ & 3999 & $9.30 \%$ & 4092 & $11.83 \%$ & $\begin{array}{l}\text { Illuminance } \\
\text { [hrs/yr] }\end{array}$ & \multirow{3}{*}{$\begin{array}{c}\text { Window to Wall } \\
\text { Ratio A: }: 55 \%- \\
\quad 100 \%\end{array}$} \\
\hline 18925 & \multirow{2}{*}{$35.79 \%$} & 18253 & \multirow{2}{*}{$30.96 \%$} & 18033 & \multirow{2}{*}{$29.15 \%$} & 17547 & \multirow{2}{*}{$25.67 \%$} & $\begin{array}{l}\text { Nat. gas } \\
\text { [kWh/yr] }\end{array}$ & \\
\hline 5114 & & 4931 & & 4831 & & 4700 & & $\begin{array}{l}\text { Electricity } \\
{[\mathrm{kWh} / \mathrm{yr}]}\end{array}$ & \\
\hline 4252 & $16.20 \%$ & 4217 & $15.23 \%$ & 3992 & $9.09 \%$ & 4092 & $11.83 \%$ & $\begin{array}{l}\text { Illuminance } \\
\text { [hrs/yr] }\end{array}$ & \multirow{3}{*}{$\begin{array}{c}\text { Window to Wal } \\
\text { Ratio B: } 55 \% \text { - } \\
65 \%\end{array}$} \\
\hline 17686 & \multirow{2}{*}{$27.99 \%$} & 17278 & \multirow{2}{*}{$24.95 \%$} & 16478 & \multirow{2}{*}{$19.69 \%$} & 16778 & \multirow{2}{*}{$21.09 \%$} & $\begin{array}{l}\text { Nat. gas } \\
\text { [kWh/yr] }\end{array}$ & \\
\hline 4972 & & 4842 & & 4711 & & 4658 & & $\begin{array}{l}\text { Electricity } \\
{[\mathrm{kWh} / \mathrm{yr}]}\end{array}$ & \\
\hline 4233 & $15.68 \%$ & 4199 & $14.76 \%$ & 3655 & $-0.11 \%$ & 4023 & $9.95 \%$ & $\begin{array}{l}\text { Illuminance } \\
\text { [hrs/yr] }\end{array}$ & \multirow{3}{*}{$\begin{array}{l}\text { Window to Wal } \\
\text { Ratio C: } 35 \% \text { - } \\
\quad 45 \%\end{array}$} \\
\hline 17058 & \multirow{2}{*}{$23.27 \%$} & 16667 & \multirow{2}{*}{$20.56 \%$} & 15925 & \multirow{2}{*}{$15.96 \%$} & 16111 & \multirow{2}{*}{$16.74 \%$} & Nat. gas & \\
\hline 4764 & & 4675 & & 4603 & & 4556 & & $\begin{array}{l}\text { Electricity } \\
{[\mathrm{kWh} / \mathrm{yr}]}\end{array}$ & \\
\hline 4230 & $15.59 \%$ & 4199 & $14.74 \%$ & 3655 & $-0.13 \%$ & 4023 & $9.95 \%$ & $\begin{array}{l}\text { Illuminance } \\
\text { [hrs/yr] }\end{array}$ & \multirow{3}{*}{$\begin{array}{l}\text { Window to Wall } \\
\text { Ratio D: } 20 \%- \\
35 \%\end{array}$} \\
\hline 16078 & \multirow{2}{*}{$6.87 \%$} & 15978 & \multirow{2}{*}{$16.16 \%$} & 15725 & \multirow{2}{*}{$14.72 \%$} & 15597 & \multirow{2}{*}{$13.64 \%$} & Nat. gas & \\
\hline 4611 & & 4586 & & 4583 & & 4519 & & $\begin{array}{l}\text { Electricity } \\
{[\mathrm{kWh} / \mathrm{rr}]}\end{array}$ & \\
\hline
\end{tabular}

*Highlighted options correspond to the best performers in the priority scales

Table 15: East orientation information chart.

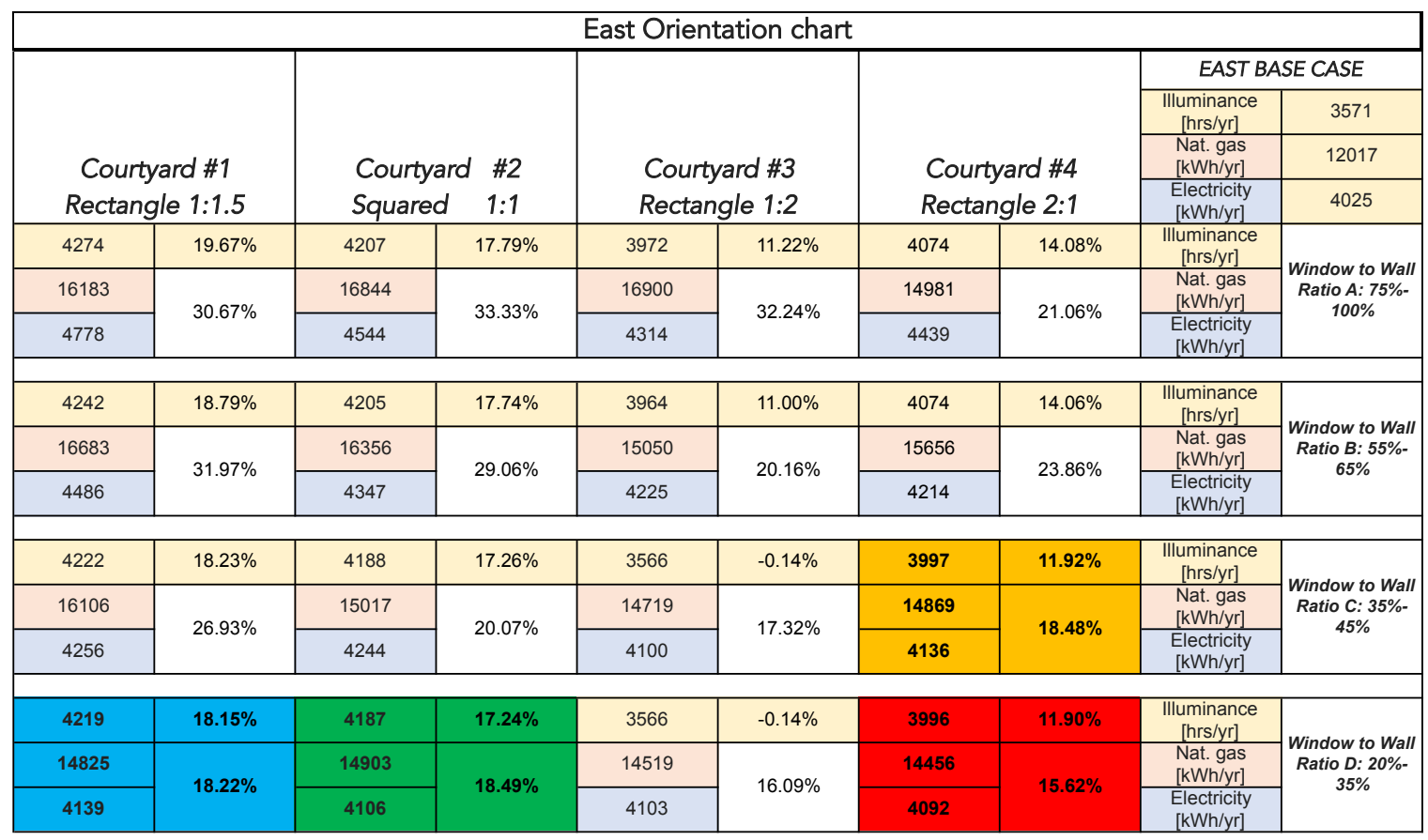

*Highlighted options correspond to the best performers in the priority scales 
Table 16: North orientation information chart.

\begin{tabular}{|c|c|c|c|c|c|c|c|c|c|}
\hline \multicolumn{10}{|c|}{ NORTH Orientation chart } \\
\hline \multirow{4}{*}{\multicolumn{2}{|c|}{$\begin{array}{c}\text { Courtyard \#1 } \\
\text { Rectangle 1:1.5 }\end{array}$}} & & & \multirow{4}{*}{\multicolumn{2}{|c|}{$\begin{array}{l}\text { Courtyard \#3 } \\
\text { Rectangle 1:2 }\end{array}$}} & \multirow{4}{*}{\multicolumn{2}{|c|}{$\begin{array}{r}\text { Courtyard \#4 } \\
\text { Rectangle 2:1 }\end{array}$}} & \multicolumn{2}{|c|}{ NORTH BASE CASE } \\
\hline & & & & & & & & $\begin{array}{c}\text { Illuminance } \\
\text { [hrs/yr] }\end{array}$ & 3661 \\
\hline & & \multirow{2}{*}{$\begin{array}{l}\text { Courtyard \#2 } \\
\text { Squared } \\
\text { Sq1 }\end{array}$} & & & & & & $\begin{array}{l}\text { Nat. gas } \\
{[\mathrm{kWh} / \mathrm{yr}]}\end{array}$ & 12053 \\
\hline & & & & & & & & $\begin{array}{l}\text { Electricity } \\
{[\mathrm{kWh} / \mathrm{yr}]}\end{array}$ & 4564 \\
\hline 4217 & $15.18 \%$ & 4217 & $15.20 \%$ & 3997 & $9.18 \%$ & 4092 & $11.78 \%$ & $\begin{array}{c}\text { Illuminance } \\
\text { [hrs/yr] }\end{array}$ & \multirow{3}{*}{$\begin{array}{c}\text { Window to Wall } \\
\text { Ratio A: } 75 \% \text { - } \\
100 \%\end{array}$} \\
\hline 17114 & \multirow{2}{*}{$33.52 \%$} & 17083 & \multirow{2}{*}{$33.35 \%$} & 17275 & \multirow{2}{*}{$32.78 \%$} & 15597 & \multirow{2}{*}{$22.40 \%$} & $\begin{array}{l}\text { Nat. gas } \\
{[\mathrm{kWh} / \mathrm{yr}]}\end{array}$ & \\
\hline 5072 & & 5075 & & 4789 & & 4742 & & $\begin{array}{l}\text { Electricity } \\
{[\mathrm{kWh} / \mathrm{yr}]}\end{array}$ & \\
\hline 4252 & $16.14 \%$ & 4216 & $15.17 \%$ & 3990 & $8.98 \%$ & 4022 & $9.87 \%$ & $\begin{array}{l}\text { Illuminance } \\
\text { [hrs/yr] }\end{array}$ & \multirow{3}{*}{$\begin{array}{c}\text { Window to Wall } \\
\text { Ratio B: } 55 \%- \\
65 \%\end{array}$} \\
\hline 16939 & \multirow{2}{*}{$32.11 \%$} & 16864 & \multirow{2}{*}{$30.17 \%$} & 15303 & \multirow{2}{*}{$20.86 \%$} & 14686 & \multirow{2}{*}{$16.62 \%$} & $\begin{array}{l}\text { Nat. gas } \\
{[\mathrm{kWh} / \mathrm{yr}]}\end{array}$ & \\
\hline 5014 & & 4767 & & 4781 & & 4692 & & $\begin{array}{l}\text { Electricity } \\
{[\mathrm{kWh} / \mathrm{yr}]}\end{array}$ & \\
\hline 4233 & $15.62 \%$ & 4199 & $14.71 \%$ & 3657 & $-0.10 \%$ & 4022 & $9.86 \%$ & $\begin{array}{l}\text { Illuminance } \\
\text { [hrs/yr] }\end{array}$ & \multirow{3}{*}{$\begin{array}{l}\text { Window to Wall } \\
\text { Ratio C: } 35 \%- \\
\quad 45 \%\end{array}$} \\
\hline 16333 & \multirow{2}{*}{$26.91 \%$} & 15653 & \multirow{2}{*}{$22.68 \%$} & 14836 & \multirow{2}{*}{$17.24 \%$} & 14339 & \multirow{2}{*}{$14.09 \%$} & $\begin{array}{l}\text { Nat. gas } \\
{[\mathrm{kWh} / \mathrm{yr}]}\end{array}$ & \\
\hline 4756 & & 4733 & & 4644 & & 4619 & & $\begin{array}{l}\text { Electricity } \\
\text { [kWh/yr] }\end{array}$ & \\
\hline 4230 & $15.54 \%$ & 4199 & $14.70 \%$ & 3656 & $-0.13 \%$ & 4022 & $9.86 \%$ & $\begin{array}{l}\text { Illuminance } \\
\text { [hrs/yr] }\end{array}$ & \\
\hline 15244 & $1953 \%$ & 15008 & $1807 \%$ & 14733 & $1623 \%$ & 14339 & $1400 \%$ & $\begin{array}{l}\text { Nat. gas } \\
{[\mathrm{kWh} / \mathrm{yr}]}\end{array}$ & $\begin{array}{l}\text { Window to Wall } \\
\text { Ratio D: } 20 \%- \\
35 \%\end{array}$ \\
\hline 4617 & 10.007 & 4611 & $10.01 \%$ & 4581 & $10.23 \%$ & 4619 & $14.09 \%$ & $\begin{array}{l}\text { Electricity } \\
{[\mathrm{kWh} / \mathrm{yr}]}\end{array}$ & \\
\hline
\end{tabular}

*Highlighted options correspond to the best performers in the priority scales

Table 17: West orientation information chart.

\begin{tabular}{|c|c|c|c|c|c|c|c|c|c|}
\hline \multicolumn{10}{|c|}{ West Orientation chart } \\
\hline \multirow{4}{*}{\multicolumn{2}{|c|}{$\begin{array}{c}\text { Courtyard \#1 } \\
\text { Rectangle 1:1.5 }\end{array}$}} & & & \multirow{4}{*}{\multicolumn{2}{|c|}{$\begin{array}{l}\text { Courtyard \#3 } \\
\text { Rectangle 1:2 }\end{array}$}} & \multirow{4}{*}{\multicolumn{2}{|c|}{$\begin{array}{l}\text { Courtyard \#4 } \\
\text { Rectangle 2:1 }\end{array}$}} & \multicolumn{2}{|c|}{ WEST BASE CASE } \\
\hline & & & & & & & & $\begin{array}{c}\text { Illuminance } \\
\text { [hrs/yr] }\end{array}$ & 3570 \\
\hline & & \multirow{2}{*}{$\begin{array}{ll}\text { Courtyard } & \# 2 \\
\text { Squared } & 1: 1\end{array}$} & & & & & & $\begin{array}{l}\text { Nat. gas } \\
{[\mathrm{kWh} / \mathrm{yr}]}\end{array}$ & 12417 \\
\hline & & & & & & & & $\begin{array}{l}\text { Electricity } \\
{[\mathrm{kWh} / \mathrm{yr}]}\end{array}$ & 4025 \\
\hline 4284 & $20.00 \%$ & 4213 & $18.01 \%$ & 3969 & $11.19 \%$ & 4072 & $14.05 \%$ & $\begin{array}{c}\text { Illuminance } \\
\text { [hrs/yr] }\end{array}$ & \multirow{3}{*}{$\begin{array}{c}\text { Window to Wall } \\
\text { Ratio A: } 75 \% \text { - } \\
100 \%\end{array}$} \\
\hline 16836 & \multirow{2}{*}{$31.20 \%$} & 17864 & \multirow{2}{*}{$35.48 \%$} & 17386 & \multirow{2}{*}{$31.91 \%$} & 15644 & \multirow{2}{*}{$21.88 \%$} & $\begin{array}{l}\text { Nat. gas } \\
{[\mathrm{kWh} / \mathrm{yr}]}\end{array}$ & \\
\hline 4736 & & 4411 & & 4303 & & 4394 & & $\begin{array}{l}\text { Electricity } \\
{[\mathrm{kWh} / \mathrm{yr}]}\end{array}$ & \\
\hline & & & & & & & & & \multirow{4}{*}{$\begin{array}{c}\text { Window to Wall } \\
\text { Ratio B: } 55 \% \text { - } \\
65 \%\end{array}$} \\
\hline 4251 & $19.07 \%$ & 4212 & $17.98 \%$ & 3961 & $10.96 \%$ & 4072 & $14.06 \%$ & $\begin{array}{l}\text { [hrs } / \mathrm{yr}] \\
\end{array}$ & \\
\hline 16950 & \multirow{2}{*}{$30.34 \%$} & 16217 & \multirow{2}{*}{$25.24 \%$} & 15881 & \multirow{2}{*}{$22.15 \%$} & 15303 & \multirow{2}{*}{$19.07 \%$} & $\begin{array}{l}\text { Nat. gas } \\
{[\mathrm{kWh} / \mathrm{yr}]}\end{array}$ & \\
\hline 4481 & & 4375 & & 4203 & & 4275 & & $\begin{array}{l}\text { Electricity } \\
\text { [kWh/yr] }\end{array}$ & \\
\hline & & & & & & & & & \multirow{4}{*}{$\begin{array}{c}\text { Window to Wall } \\
\text { Ratio C: } 35 \% \text { - } \\
45 \%\end{array}$} \\
\hline 4231 & $18.51 \%$ & 4193 & $17.44 \%$ & 3565 & $-0.14 \%$ & 3994 & $11.87 \%$ & [hrs/yr] & \\
\hline 15581 & \multirow{2}{*}{$21.64 \%$} & 15553 & \multirow{2}{*}{$20.16 \%$} & 15139 & \multirow{2}{*}{$16.96 \%$} & 14831 & \multirow{2}{*}{$15.36 \%$} & $\begin{array}{l}\text { Nat. gas } \\
{[\mathrm{kWh} / \mathrm{yr}]}\end{array}$ & \\
\hline 4419 & & 4203 & & 4092 & & 4136 & & $\begin{array}{l}\text { Electricity } \\
\text { [kWh/yr] }\end{array}$ & \\
\hline & & & & & & & & & \multirow{4}{*}{$\begin{array}{c}\text { Window to Wall } \\
\text { Ratio D: 20\%- } \\
35 \%\end{array}$} \\
\hline 4227 & $18.41 \%$ & 4192 & $17.43 \%$ & 3565 & $-0.15 \%$ & 3993 & $11.86 \%$ & [hrs/yr] & \\
\hline 15219 & \multirow{2}{*}{$17.64 \%$} & 15308 & \multirow{2}{*}{$18.04 \%$} & 14933 & \multirow{2}{*}{$15.70 \%$} & 14533 & \multirow{2}{*}{$13.30 \%$} & $\begin{array}{l}\text { Nat. gas } \\
\text { [kWh/yr] }\end{array}$ & \\
\hline 4122 & & 4100 & & 4089 & & 4094 & & $\begin{array}{l}\text { Electricity } \\
\text { [kWh/yr] }\end{array}$ & \\
\hline
\end{tabular}

*Highlighted options correspond to the best performers in the priority scales 


\subsection{Summary of results}

The information compiled in this study aim to provide a tool for designers that want to include an internal courtyard in a row house project, helping to understand what are the implications of size, window to wall ratios and orientation. Under the boundary conditions established, the results of this study show significant improvement on the amount of time that the light is able to get into the centre of a row house through an internal courtyard.

Fifty-six examined configurations show improvement in the hours of illuminance, ranging between $9 \%$ and $20 \%$ more hours per year compared to their base cases.

In houses using low energy lights like CFLs or LEDs, when including an internal courtyard the energy saved by the reduction of the energy on artificial lighting is low. In these cases the savings range from $1.14 \%$ to $1.42 \%$ of energy savings per year. Higher benefits might be achieved in houses that use incandescent lights as in North America are still not phased out.

A moderate increase on the hours of illuminance was found in the locations $3.85 \mathrm{~m}$ away from the front and back windows, as these areas are already receiving good illuminance. However, significant improvements are noted in the middle of the floor plan, which is usually much darker, with increases in the hours of illuminance especially in the winter months. 
When designing small rectangular courtyards located parallel to the party wall, the larger window to wall ratios should be used to make any improvement in the hours of illuminance.

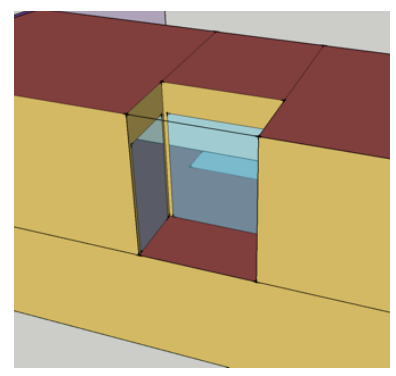

Courtyard 3-A

WWR 100\%

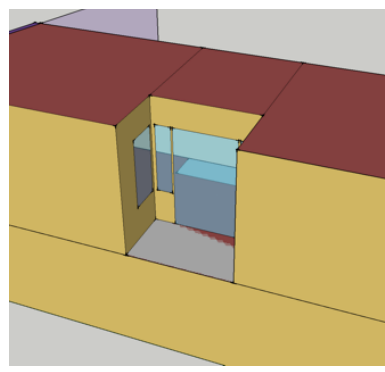

Courtyard 3-B

WWR 55\%

The general trend shows that the months with shorter days have a higher increase in daylight hours compared to months where the days are longer. This means that the days when light is more sought, the internal courtyard offers better results. In winter days the hours of illuminance above 100 lux are reached around 8.15AM in some options with internal courtyards, when a row house without one gets those hours of illuminance around 9AM. On the afternoon the light extends from 3PM to 4PM.

Sensor reaching 100 lux

Sunset/Sunrise

in the West base case

(No courtyard)

5:38hs/19:00hs

(Total13.33hs)

6:46hs/17:26hs

(Total10.66hs)

9:02hs/15:02hs

(Total 5.64hs)

(Total 8.94hs)
Sensor reaching 100 lux in Courtyard 1-A West

4.51hs/19:45hs

(Total 14.9hs)

6:02hs/18.11hs

(Total12.13hs)

8:15hs/16.12hs

(Total7.93hs)

15th

(Total7.93hs)


The window to wall ratio above $55 \%$ shows no major influence on the hours of illuminance within the larger courtyards ( 1 and 2 ). When using courtyard 4 the WWR does make a larger difference compared to courtyards 1 and 2 but still no more than 10 hours per month. This provides opportunities to iterate WWR without loosing illuminance improvements.

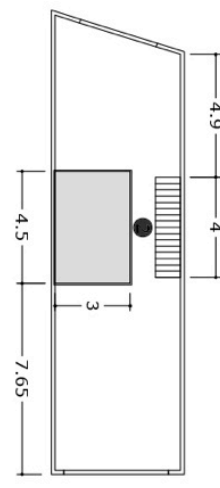

Courtyard 1

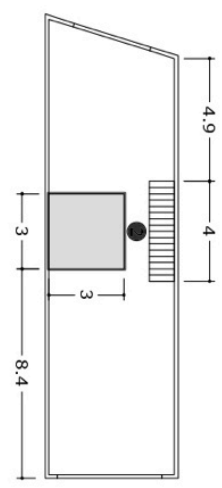

Courtyard 2

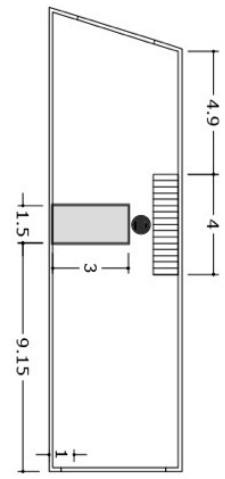

Courtyard 4

When using courtyard 3 the

illuminance hours show no

difference from the base

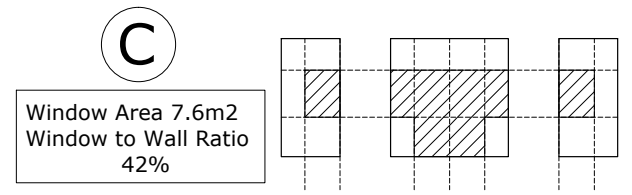

cases on the options with

WWR below $42 \%$. If the

improvement of the light is

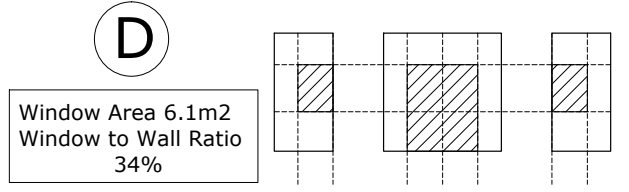

the main goal, the $C$ and $D$ configurations are not recommended to be used as they don't provide any improvement in the amount

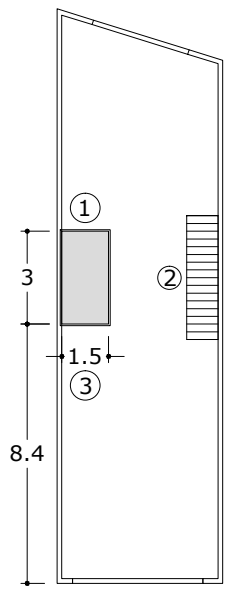

Courtyard 3 of hours of illuminance over 100 lux. When including courtyard 3 in a row house only higher WWR should be used if it is expected to improve the light inside the house. 
Row houses with internal courtyards use between $13 \%$ and $36 \%$ more energy that their base cases. Most of the smaller sized courtyards are located within the group using less energy while the options with larger courtyards are more distributed on the higher energy use side.

The window to wall ratio (WWR) also influences the distribution of the results. Courtyards with smaller WWR generally have lower energy use since they have reduced heat loss, while small courtyard configurations result in lower hours of illuminance compared to their base cases. For low energy consumption it is recommended to design internal courtyards with WWR ranging from $20 \%$ to $42 \%$

To maximize the combined benefit of low energy use and improvement illuminance, the best performers are shown to be 2-D (large squared courtyard with the lowest WWR) and 1-D (large rectangular courtyard with the lowest WWR) oriented to the East and West. Both show the best combination of illuminance increases and energy use in all orientations, ranging from $14.7 \%$ to $18.4 \%$ increase of hours of light, while having an increase in the energy consumption between $16.1 \%$ to $19.5 \%$.

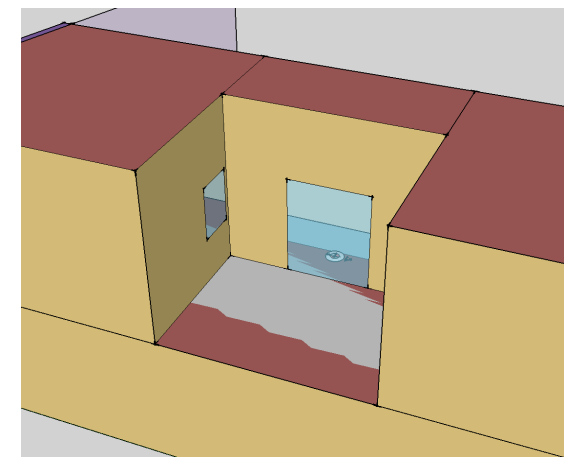

Courtyard 1-D

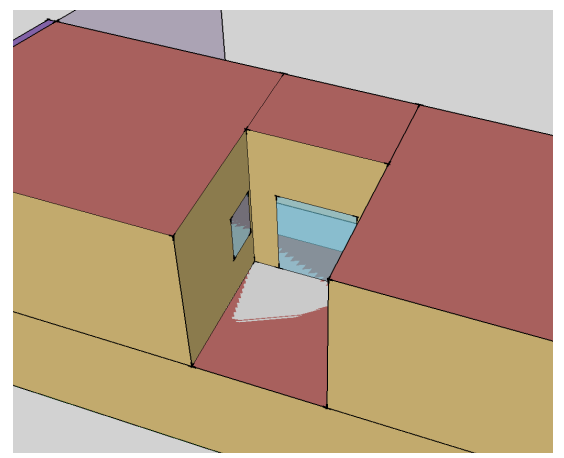

Courtyard 2-D 
The South oriented options show an overall higher energy use and do not show the best performance for illuminance hours increase either. But further analysis should be conducted to understand the values on a monthly basis considering the moments of the year when light is more sought.

The East and West orientations show highest hours of illuminance compared to the South and North orientations. But further analysis on a monthly basis should be conducted to verify if that increment is beneficial.

According to the six priority scales established, courtyards 2-D, 1-D, 4-C and 4-D tend to be the best group of options to be used for any orientation.

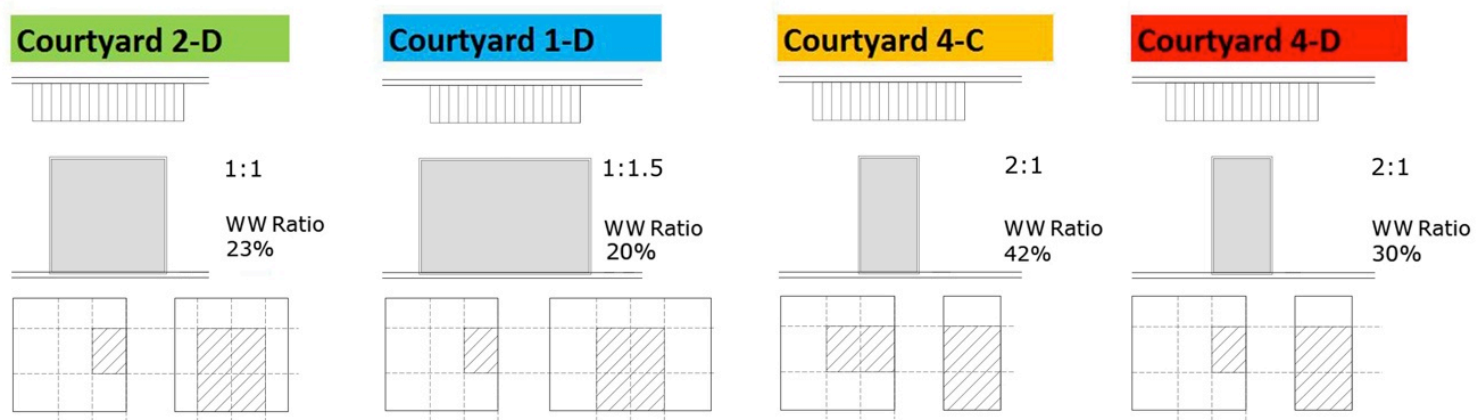




\section{Conclusions}

- Energy savings in artificial light appears to be minimal when introducing internal courtyards and using low energy bulbs.

- The row houses with internal courtyards use between $13 \%$ and $36 \%$ more energy on heating and cooling compared to a row house without one, while improving the illuminance hours between $9 \%$ and $20 \%$.

- The months with shorter days show higher increments of hours comparing to the days that are longer. The internal courtyard provides an even better response when the light is more needed indoors, showing that in the winter months there is an increase of over two hours of illuminance compared to a row house without one.

- Four options are recommended as best performers in all the priority scales. The ones with largest courtyard footprints will result in better illuminance hours with small differences on the energy use increase.

- Window to wall ratios inside internal courtyards have an important influence in the energy load while not much in the illuminance. A WWR between $20 \%$ to $42 \%$ is recommended to reduce the energy consumption while maintaining similar illuminance time increment.

- The internal courtyard provides a unique opportunity to maximize the time with natural light inside the row house, providing an improvement in the winter indoor-living experience in a colder climate location like Toronto. 


\section{Recommended work for the future}

While South and North orientations should have an even distributed increase in the hours of illuminance early and later in the day, further analysis should be conducted to understand how that increment is distributed in the East and West orientations. It would be interesting to understand when are the hours of illuminance increments happening and if they are beneficial or detrimental. The distribution of the light throughout the house and the contrasts generated according to the time of the day could provide further information to optimize the location of the windows.

Further analysis geared towards optimizing passive solar strategies should be considered. Awnings, film glass, cross ventilation and perennial landscape could lower the heat gains in the summer and improve the energy performance. Windows and assemblies with higher insulation values could be considered in future work to get a better performance in the winter heat loads.

The thermal mass within the courtyard could provide benefits on balancing the peak loads. Perennial landscape could be also considered to complement the thermal mass strategy to protect from the sun in summer while providing a path in winter.

The combination of an open courtyard in the summer and an enclosed one in the winter could be considered in future research as a way to optimize the potential benefits of a greenhouse in the winter and cross ventilation in the summer. 


\section{Appendices}

APPENDIX A - SOUTH ORIENTATION RESULTS

APPENDIX B - EAST ORIENTATION RESULTS

APPENDIX C - NORTH ORIENTATION RESULTS

APPENDIX D - WEST ORIENTATION RESULTS

APPENDIX E - ENERGY BILLS CALIBRATION

APPENDIX F - UTILITY COST - 2014 BASE

APPENDIX G - BUILDING CODE AND ZONING

APPENDIX H - EXISTING HOUSE

APPENDIX I - ILLUMINANCE INCREASE VS. HEATING AND COOLING ENERGY INCREASE 


\section{Appendix A - South orientation results}

\begin{tabular}{|c|c|c|c|c|c|c|c|c|c|}
\hline \multicolumn{10}{|c|}{ SOUTH Orientation chart } \\
\hline \multirow{4}{*}{\multicolumn{2}{|c|}{$\begin{array}{c}\text { Courtyard \#1 } \\
\text { Rectangle 1:1.5 }\end{array}$}} & & & \multirow{4}{*}{\multicolumn{2}{|c|}{$\begin{array}{l}\text { Courtyard \#3 } \\
\text { Rectangle 1:2 } \\
\end{array}$}} & \multirow{4}{*}{\multicolumn{2}{|c|}{$\begin{array}{c}\text { Courtyard \#4 } \\
\text { Rectangle 2:1 }\end{array}$}} & \multicolumn{2}{|c|}{ SOUTH BASE CASE } \\
\hline & & & & & & & & $\begin{array}{c}\text { Illuminance } \\
\text { [hrs/yr] }\end{array}$ & 3659 \\
\hline & & \multirow{2}{*}{$\begin{array}{ll}\text { Courtyard } & \# 2 \\
\text { Squared } & 1: 1 \\
\end{array}$} & & & & & & $\begin{array}{l}\text { Nat. gas } \\
{[\mathrm{kWh} / \mathrm{yr}]}\end{array}$ & 13214 \\
\hline & & & & & & & & $\begin{array}{l}\text { Electricity } \\
{[\mathrm{kWh} / \mathrm{yr}]}\end{array}$ & 4489 \\
\hline 4254 & $16.27 \%$ & 4218 & $15.26 \%$ & 3999 & $9.30 \%$ & 4092 & $11.83 \%$ & $\begin{array}{l}\text { Illuminance } \\
\text { [hrs/yr] }\end{array}$ & \multirow{3}{*}{$\begin{array}{c}\text { Window to Wall } \\
\text { Ratio A: } 75 \%- \\
100 \%\end{array}$} \\
\hline 18925 & \multirow{2}{*}{$35.79 \%$} & 18253 & \multirow{2}{*}{$30.96 \%$} & 18033 & \multirow{2}{*}{$29.15 \%$} & 17547 & \multirow{2}{*}{$25.67 \%$} & $\begin{array}{l}\text { Nat. gas } \\
{[\mathrm{kWh} / \mathrm{yr}]}\end{array}$ & \\
\hline 5114 & & 4931 & & 4831 & & 4700 & & $\begin{array}{l}\text { Electricity } \\
\text { [kWh/yr] }\end{array}$ & \\
\hline 4252 & $16.20 \%$ & 4217 & $15.23 \%$ & 3992 & $9.09 \%$ & 4092 & $11.83 \%$ & $\begin{array}{c}\text { Illuminance } \\
{[\mathrm{hrs} / \mathrm{yr}]}\end{array}$ & \multirow{3}{*}{$\begin{array}{c}\text { Window to Wall } \\
\text { Ratio B: } 55 \%- \\
65 \%\end{array}$} \\
\hline 17686 & \multirow{2}{*}{$27.99 \%$} & 17278 & \multirow{2}{*}{$24.95 \%$} & 16478 & \multirow{2}{*}{$19.69 \%$} & 16778 & \multirow{2}{*}{$21.09 \%$} & $\begin{array}{l}\text { Nat. gas } \\
{[\mathrm{kWh} / \mathrm{yr}]}\end{array}$ & \\
\hline 4972 & & 4842 & & 4711 & & 4658 & & $\begin{array}{l}\text { Electricity } \\
{[\mathrm{kWh} / \mathrm{yr}]}\end{array}$ & \\
\hline 4233 & $15.68 \%$ & 4199 & $14.76 \%$ & 3655 & $-0.11 \%$ & 4023 & $9.95 \%$ & $\begin{array}{l}\text { Illuminance } \\
\text { [hrs/yr] }\end{array}$ & \multirow{3}{*}{$\begin{array}{c}\text { Window to Wall } \\
\text { Ratio C: } 35 \%- \\
\quad 45 \%\end{array}$} \\
\hline 17058 & \multirow{2}{*}{$23.27 \%$} & 16667 & \multirow{2}{*}{$20.56 \%$} & 15925 & \multirow{2}{*}{$15.96 \%$} & 16111 & \multirow{2}{*}{$16.74 \%$} & $\begin{array}{l}\text { Nat. gas } \\
{[\mathrm{kWh} / \mathrm{yr}]}\end{array}$ & \\
\hline 4764 & & 4675 & & 4603 & & 4556 & & $\begin{array}{l}\text { Electricity } \\
{[\mathrm{kWh} / \mathrm{yr}]}\end{array}$ & \\
\hline 4230 & $15.59 \%$ & 4199 & $14.74 \%$ & 3655 & $-0.13 \%$ & 4023 & $9.95 \%$ & $\begin{array}{l}\text { Illuminance } \\
\text { [hrs/yr] }\end{array}$ & \multirow{3}{*}{$\begin{array}{c}\text { Window to Wall } \\
\text { Ratio D: } 20 \%- \\
35 \%\end{array}$} \\
\hline 16078 & \multirow{2}{*}{$16.87 \%$} & 15978 & \multirow{2}{*}{$16.16 \%$} & 15725 & \multirow{2}{*}{$14.72 \%$} & 15597 & \multirow{2}{*}{$13.64 \%$} & $\begin{array}{l}\text { Nat. gas } \\
\text { [kWh/rr] }\end{array}$ & \\
\hline 4611 & & 4586 & & 4583 & & 4519 & & $\begin{array}{l}\text { Electricity } \\
{[\mathrm{kWh} / \mathrm{yr}]}\end{array}$ & \\
\hline
\end{tabular}

*Highlighted options correspond to the best performers in the priority scales

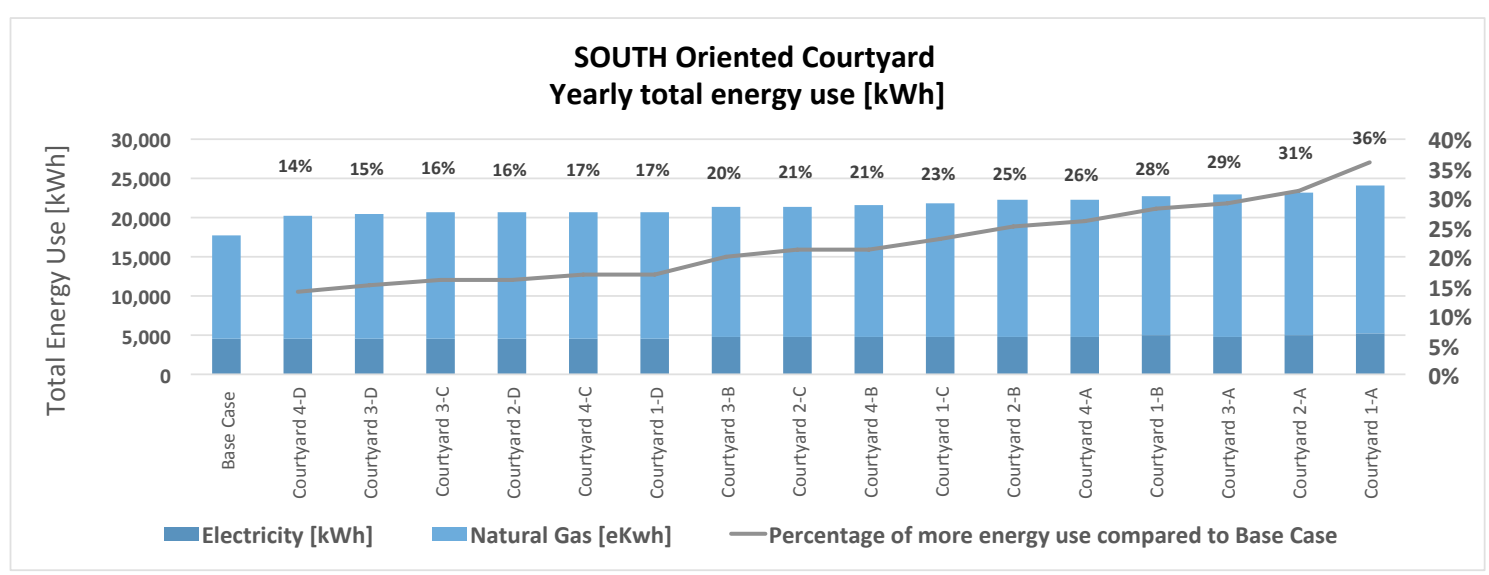


Appendix A - South Orientation Results
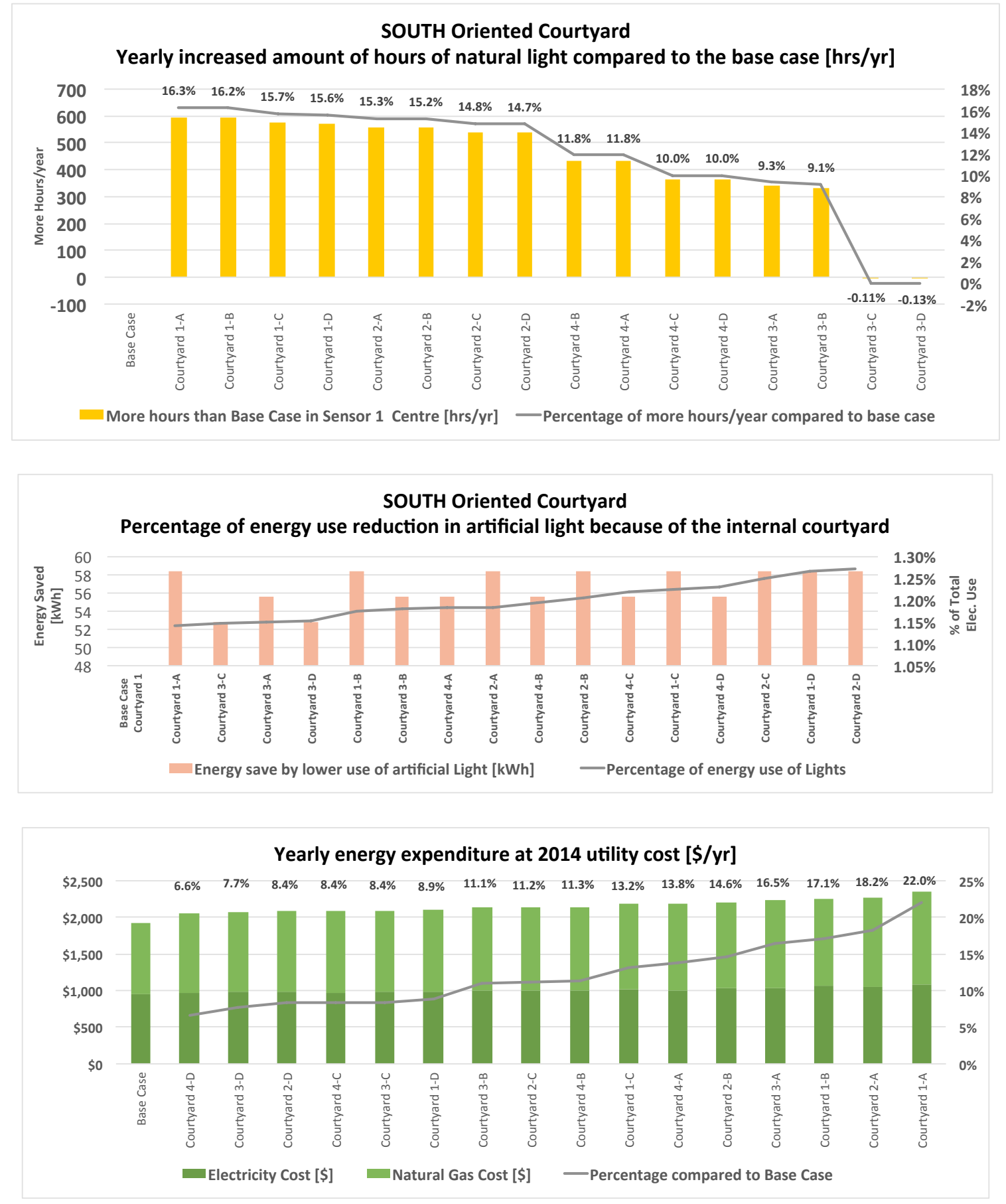

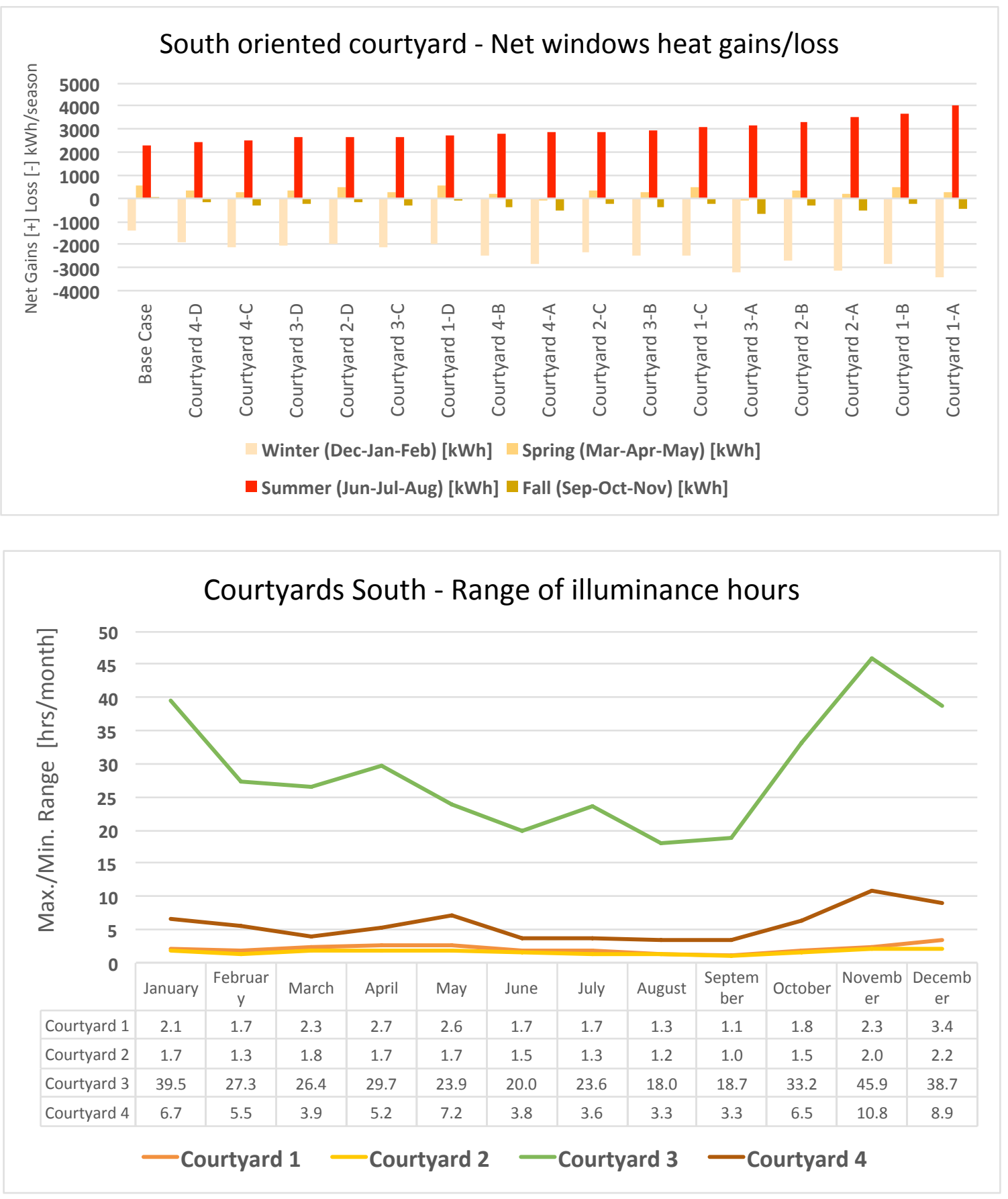


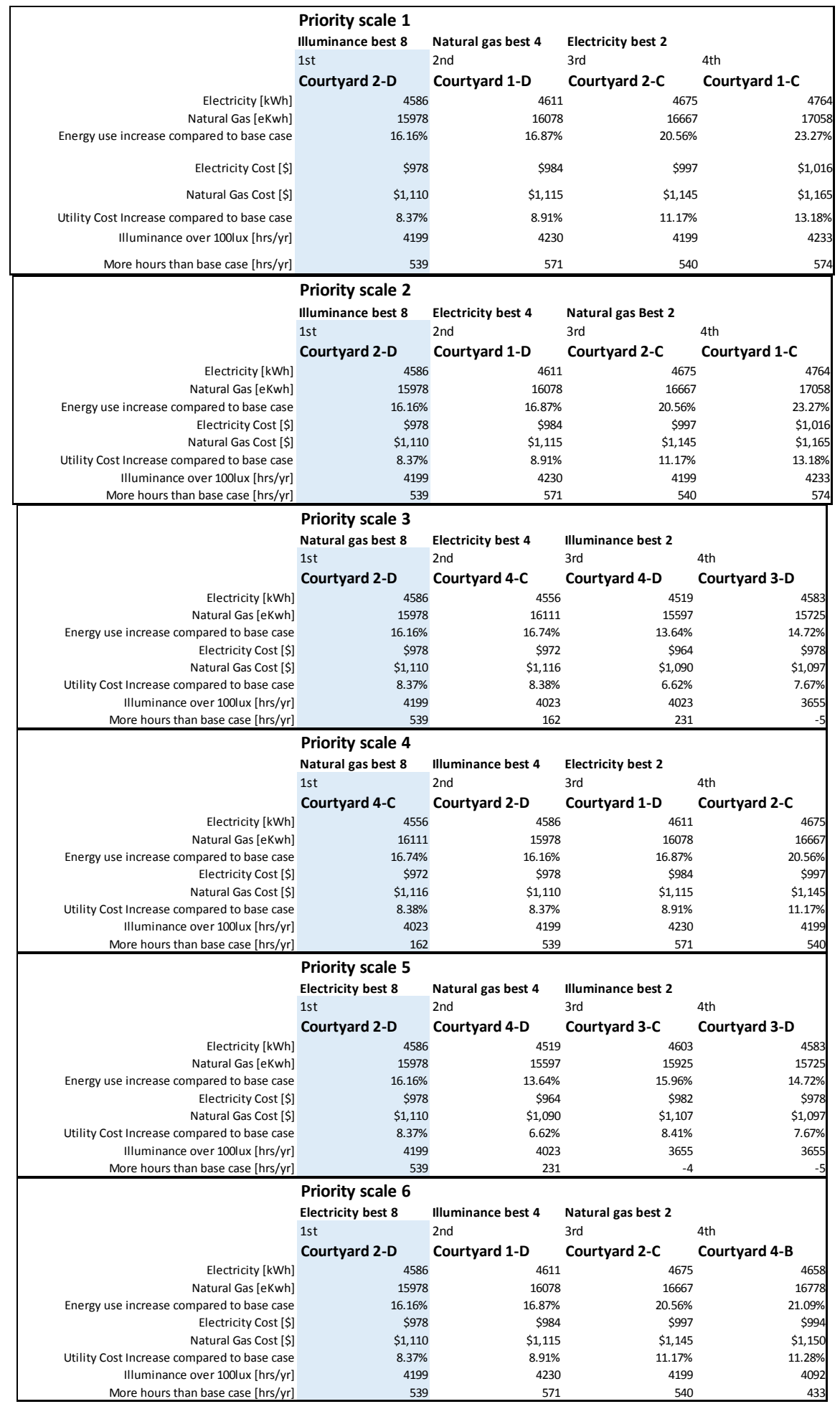


Appendix A - South Orientation Results - Courtyard 1 SOUTH
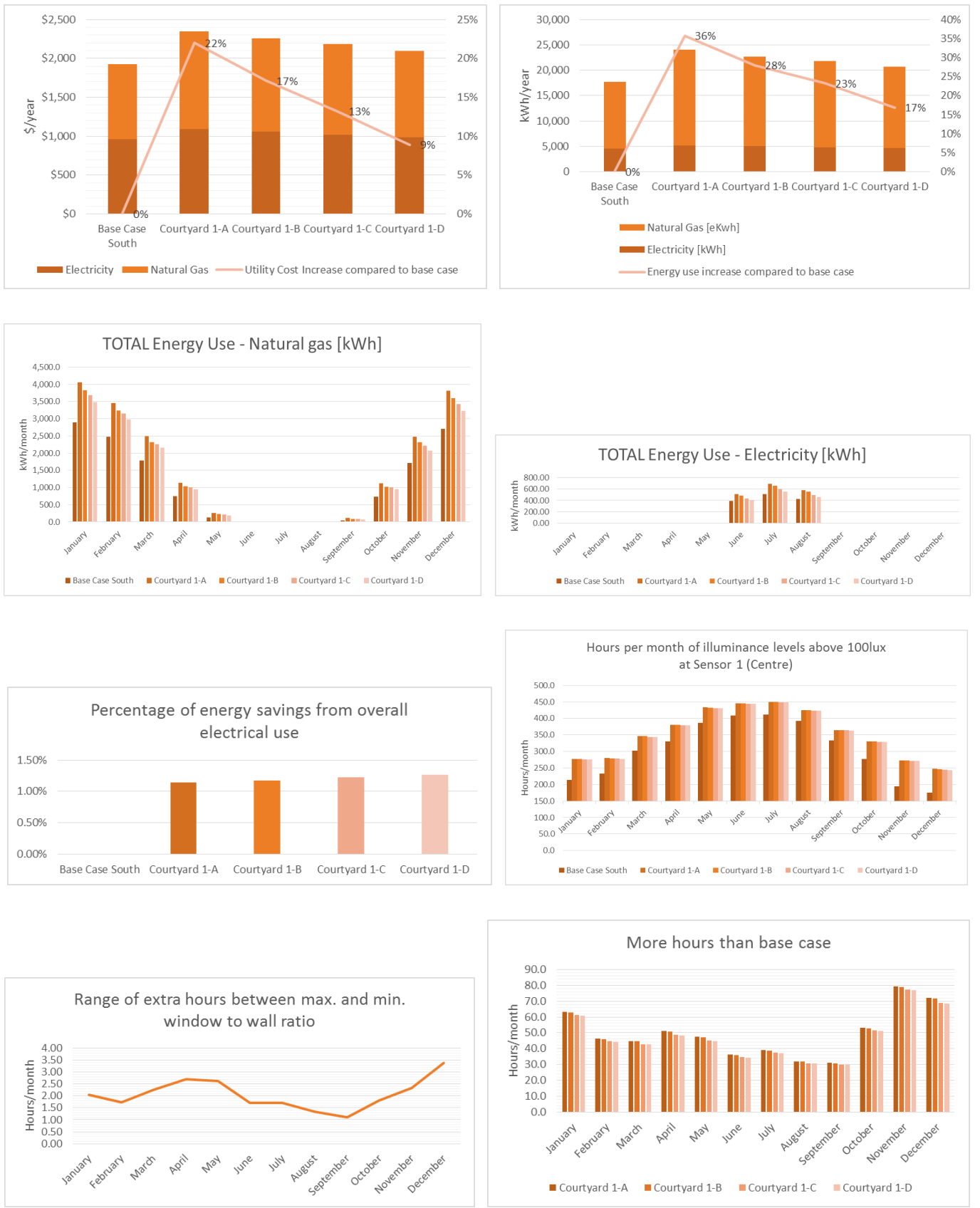
Appendix A - South Orientation Results - Courtyard 2 SOUTH
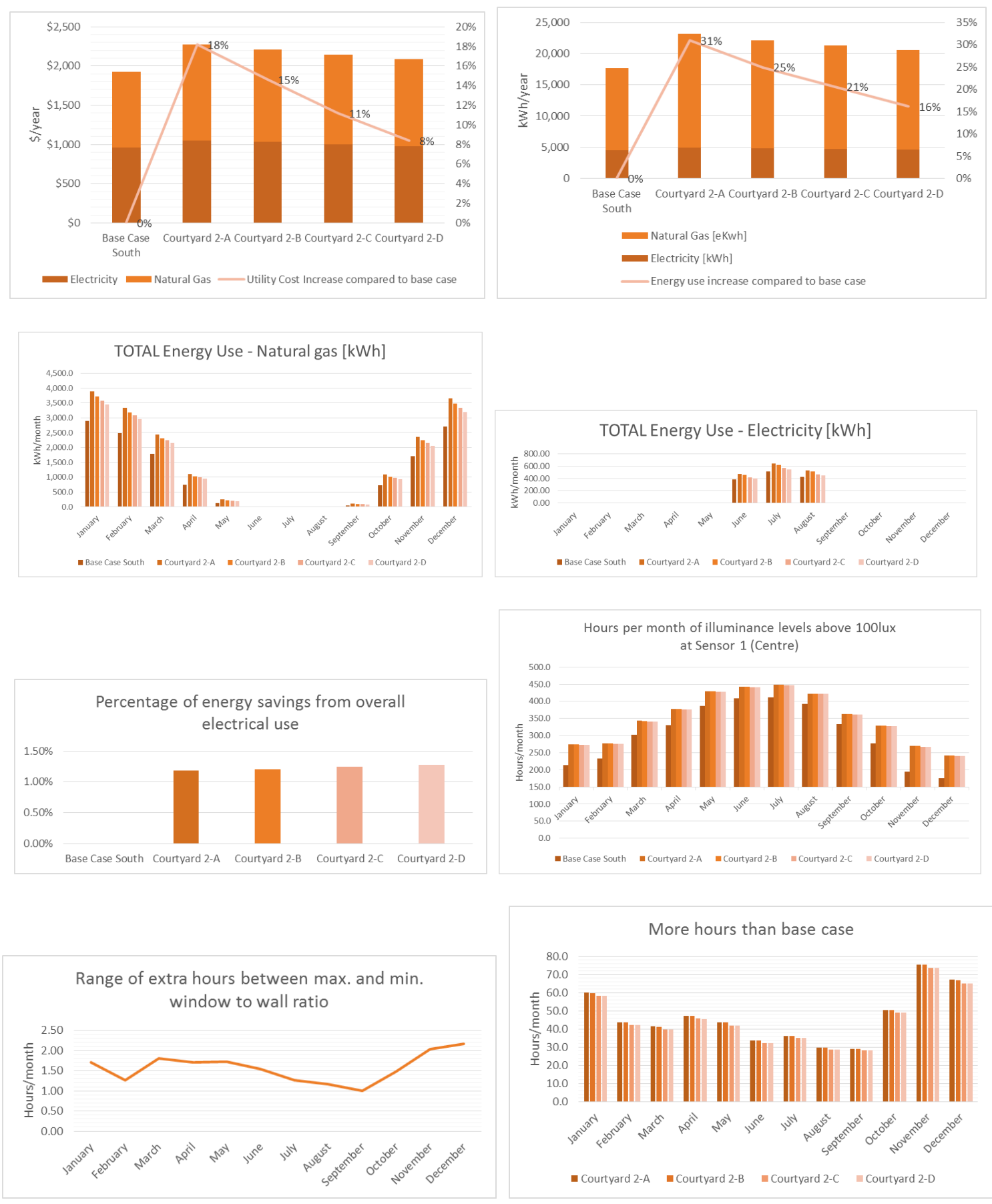
Appendix A - South Orientation Results - Courtyard 3 SOUTH
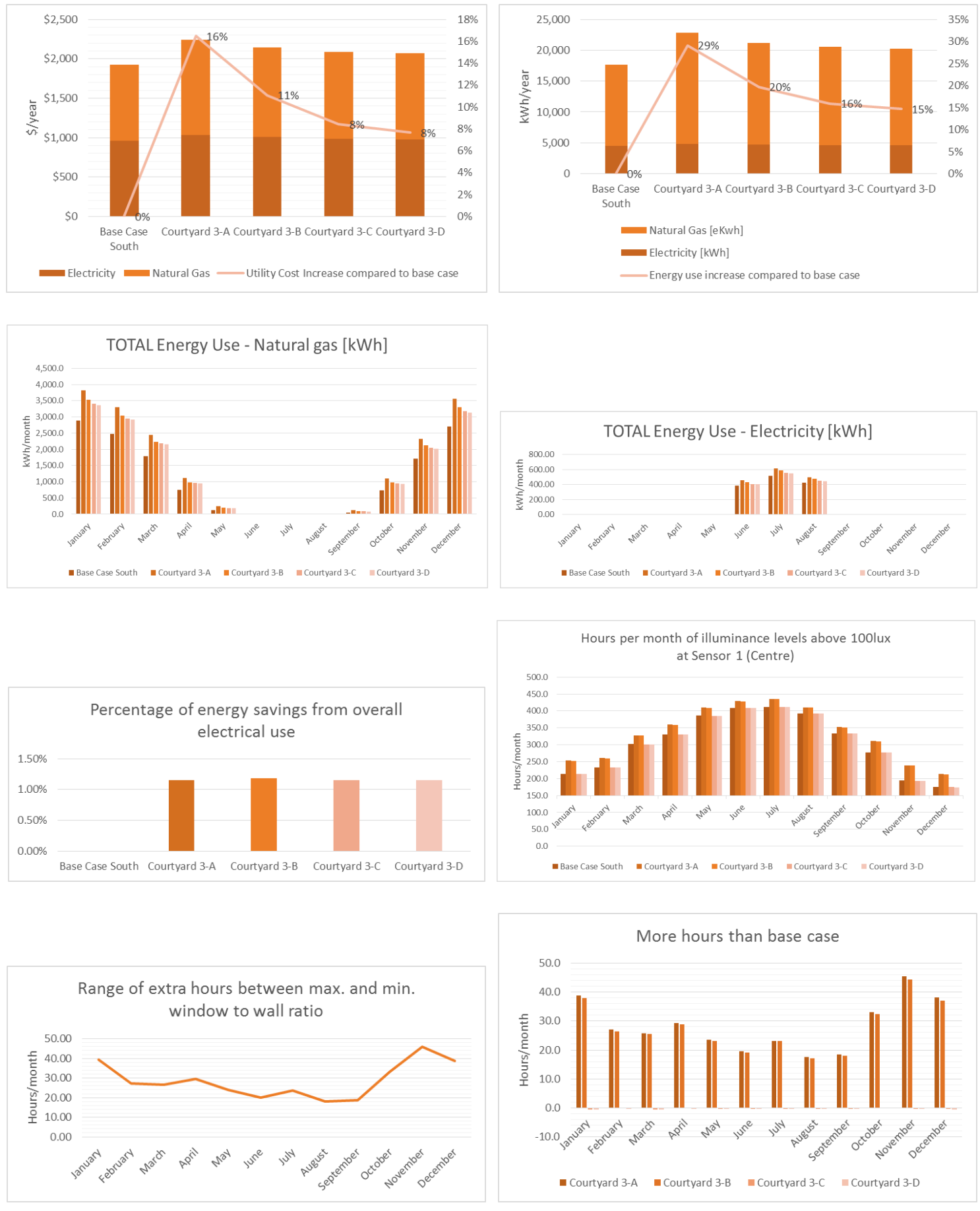
Appendix A - South Orientation Results - Courtyard 4 SOUTH
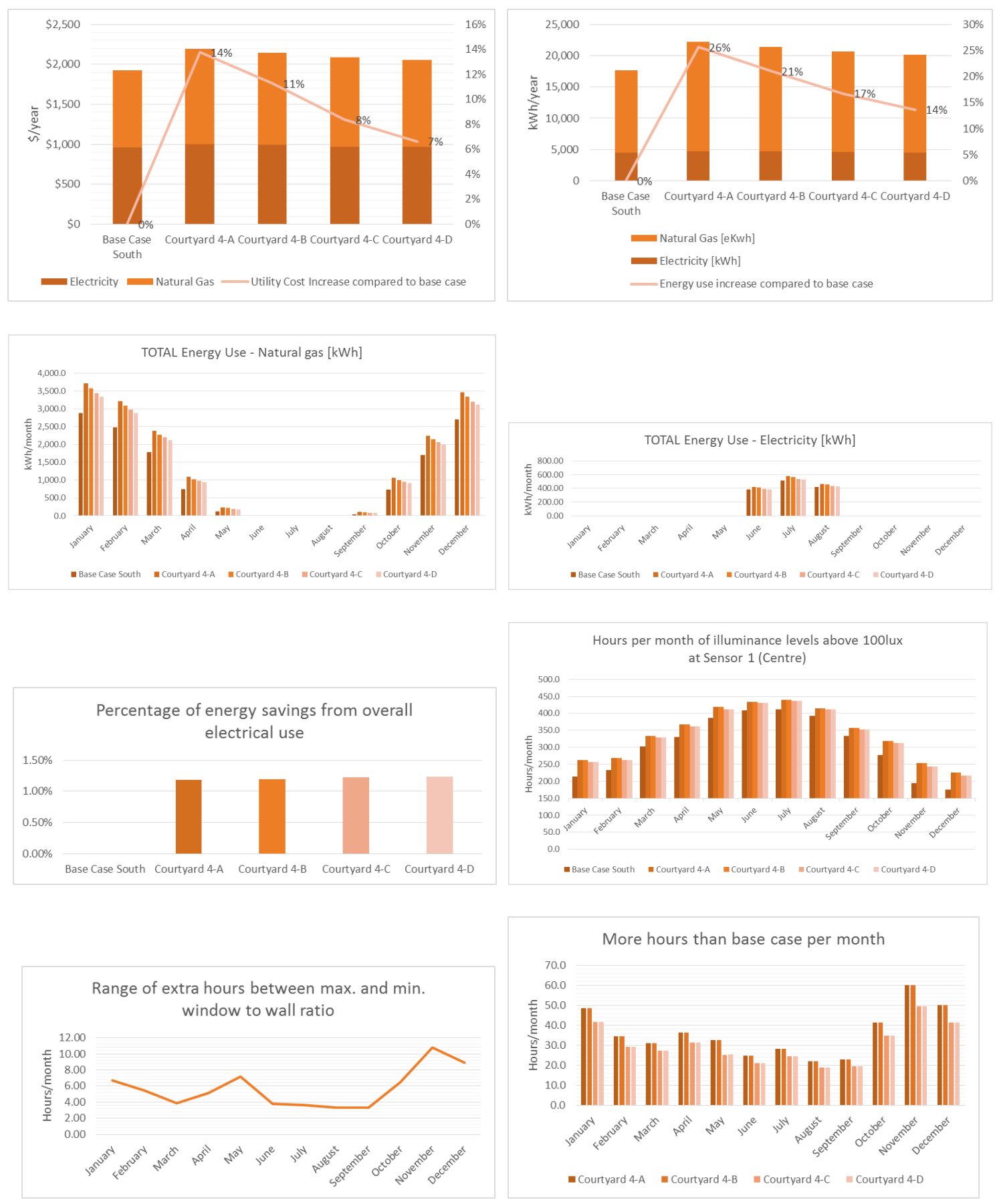


\section{Appendix B - East orientation results}

\begin{tabular}{|c|c|c|c|c|c|c|c|c|c|}
\hline \multicolumn{10}{|c|}{ East Orientation chart } \\
\hline \multirow{4}{*}{\multicolumn{2}{|c|}{$\begin{array}{c}\text { Courtyard \#1 } \\
\text { Rectangle 1:1.5 }\end{array}$}} & & & \multirow{4}{*}{\multicolumn{2}{|c|}{$\begin{array}{l}\text { Courtyard \#3 } \\
\text { Rectangle 1:2 }\end{array}$}} & \multirow{4}{*}{\multicolumn{2}{|c|}{$\begin{array}{l}\text { Courtyard \#4 } \\
\text { Rectangle 2:1 }\end{array}$}} & \multicolumn{2}{|c|}{ EAST BASE CASE } \\
\hline & & & & & & & & $\begin{array}{c}\text { Illuminance } \\
\text { [hrs/yr] }\end{array}$ & 3571 \\
\hline & & \multirow{2}{*}{$\begin{array}{ll}\text { Courtyard } & \# 2 \\
\text { Squared } & 1: 1\end{array}$} & & & & & & $\begin{array}{l}\text { Nat. gas } \\
{[\mathrm{kWh} / \mathrm{yr}]}\end{array}$ & 12017 \\
\hline & & & & & & & & $\begin{array}{l}\text { Electricity } \\
{[\mathrm{kWh} / \mathrm{yr}]}\end{array}$ & 4025 \\
\hline 4274 & $19.67 \%$ & 4207 & $17.79 \%$ & 3972 & $11.22 \%$ & 4074 & $14.08 \%$ & $\begin{array}{c}\text { Illuminance } \\
\text { [hrs/yr] }\end{array}$ & \multirow{3}{*}{$\begin{array}{c}\text { Window to Wal } \\
\text { Ratio A: } 75 \%- \\
100 \%\end{array}$} \\
\hline 16183 & \multirow{2}{*}{$30.67 \%$} & 16844 & \multirow{2}{*}{$33.33 \%$} & 16900 & \multirow{2}{*}{$32.24 \%$} & 14981 & \multirow{2}{*}{$21.06 \%$} & $\begin{array}{l}\text { Nat. gas } \\
{[\mathrm{kWh} / \mathrm{yr}]}\end{array}$ & \\
\hline 4778 & & 4544 & & 4314 & & 4439 & & $\begin{array}{l}\text { Electricity } \\
{[\mathrm{kWh} / \mathrm{yr}]}\end{array}$ & \\
\hline 4242 & $18.79 \%$ & 4205 & $17.74 \%$ & 3964 & $11.00 \%$ & 4074 & $14.06 \%$ & Illuminance & \multirow{3}{*}{$\begin{array}{c}\text { Window to Wall } \\
\text { Ratio B: } 55 \% \text { - } \\
65 \%\end{array}$} \\
\hline 16683 & \multirow{2}{*}{$31.97 \%$} & 16356 & \multirow{2}{*}{$29.06 \%$} & 15050 & \multirow{2}{*}{$20.16 \%$} & 15656 & \multirow{2}{*}{$23.86 \%$} & $\begin{array}{c}\text { [nrs/yr] } \\
\text { Nat. gas } \\
\text { [kWh/yr] }\end{array}$ & \\
\hline 4486 & & 4347 & & 4225 & & 4214 & & $\begin{array}{l}\text { Electricity } \\
{[\mathrm{kWh} / \mathrm{yr}]}\end{array}$ & \\
\hline 4222 & $18.23 \%$ & 4188 & $17.26 \%$ & 3566 & $-0.14 \%$ & 3997 & $11.92 \%$ & Illuminance & \multirow{3}{*}{$\begin{array}{c}\text { Window to Wall } \\
\text { Ratio C: } 35 \%- \\
45 \%\end{array}$} \\
\hline 16106 & \multirow{2}{*}{$26.93 \%$} & 15017 & \multirow{2}{*}{$20.07 \%$} & 14719 & \multirow{2}{*}{$17.32 \%$} & 14869 & \multirow{2}{*}{$18.48 \%$} & $\begin{array}{l}\text { Nat. gas } \\
\text { [kWh/yr] }\end{array}$ & \\
\hline 4256 & & 4244 & & 4100 & & 4136 & & $\begin{array}{l}\text { Electricity } \\
{[\mathrm{kWh} / \mathrm{yr}]}\end{array}$ & \\
\hline 4219 & $18.15 \%$ & 4187 & $17.24 \%$ & 3566 & $-0.14 \%$ & 3996 & $11.90 \%$ & $\begin{array}{l}\text { Illuminance } \\
\text { [hrs/yr] }\end{array}$ & \multirow{3}{*}{$\begin{array}{c}\text { Window to Wall } \\
\text { Ratio D: } 20 \%- \\
35 \%\end{array}$} \\
\hline 14825 & \multirow{2}{*}{$18.22 \%$} & 14903 & \multirow{2}{*}{$18.49 \%$} & 14519 & 16000 & 14456 & 150 & $\begin{array}{l}\text { Nat. gas } \\
{[\mathrm{kWh} / \mathrm{yr}]}\end{array}$ & \\
\hline 4139 & & 4106 & & 4103 & & 4092 & & $\begin{array}{l}\text { Electricity } \\
\text { [kWh/yr] }\end{array}$ & \\
\hline
\end{tabular}

*Highlighted options correspond to the best performers in the priority scales

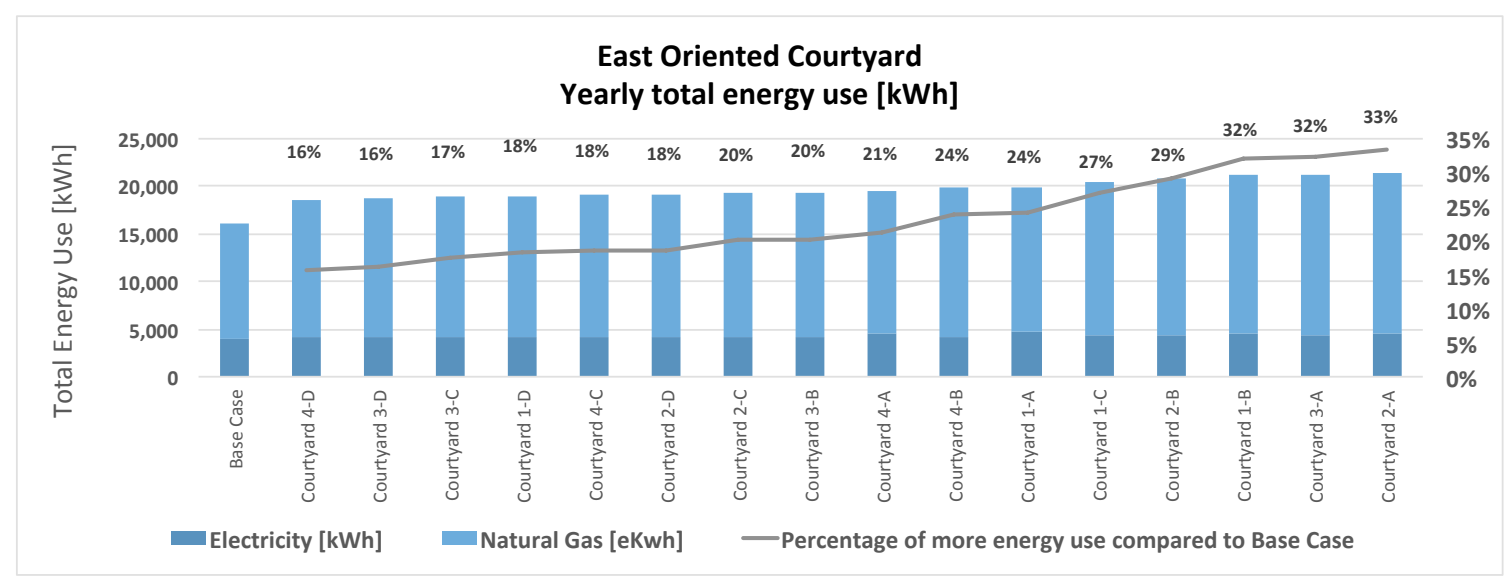


Appendix B - East Orientation Results
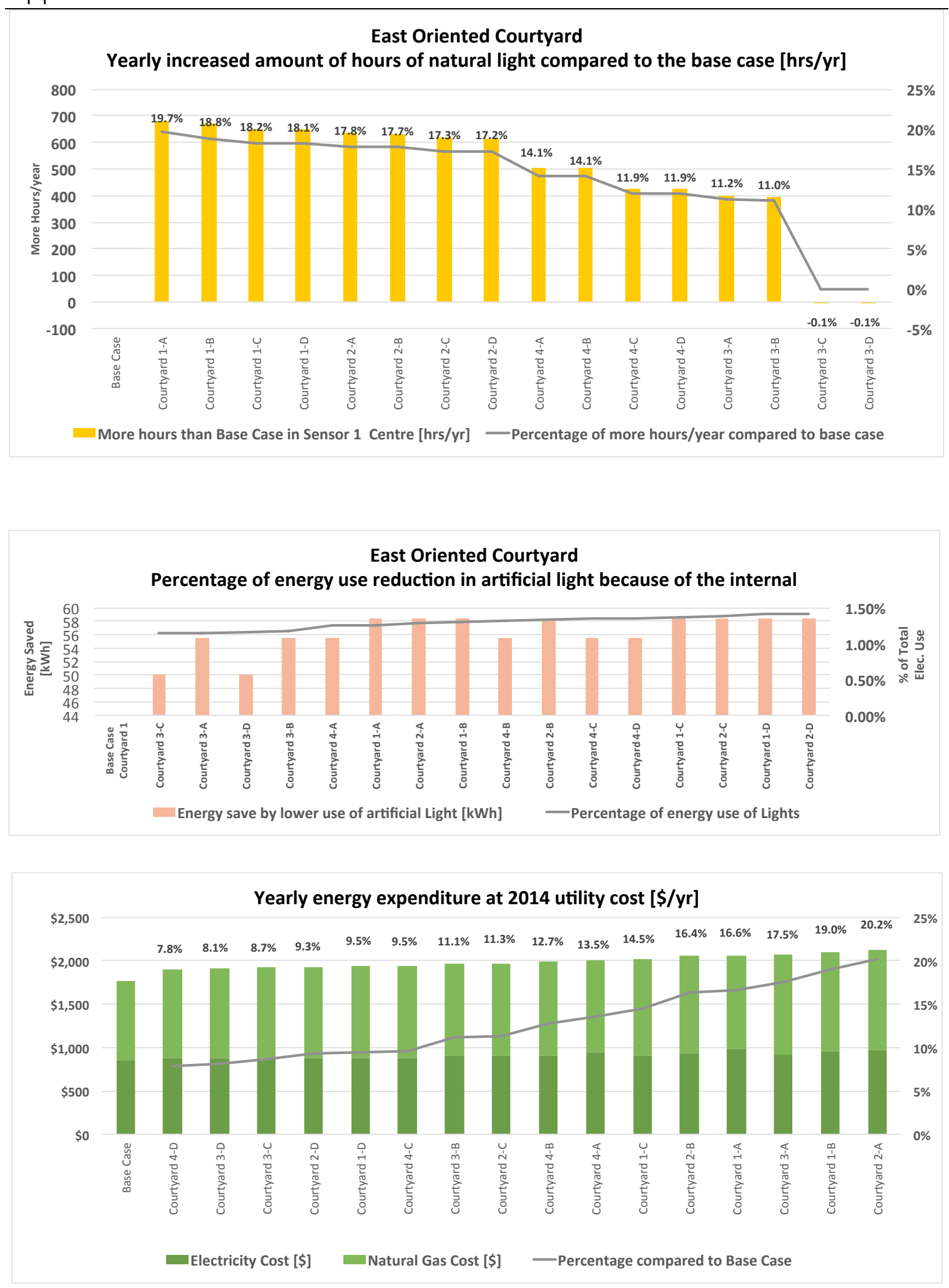
Appendix B - East Orientation Results
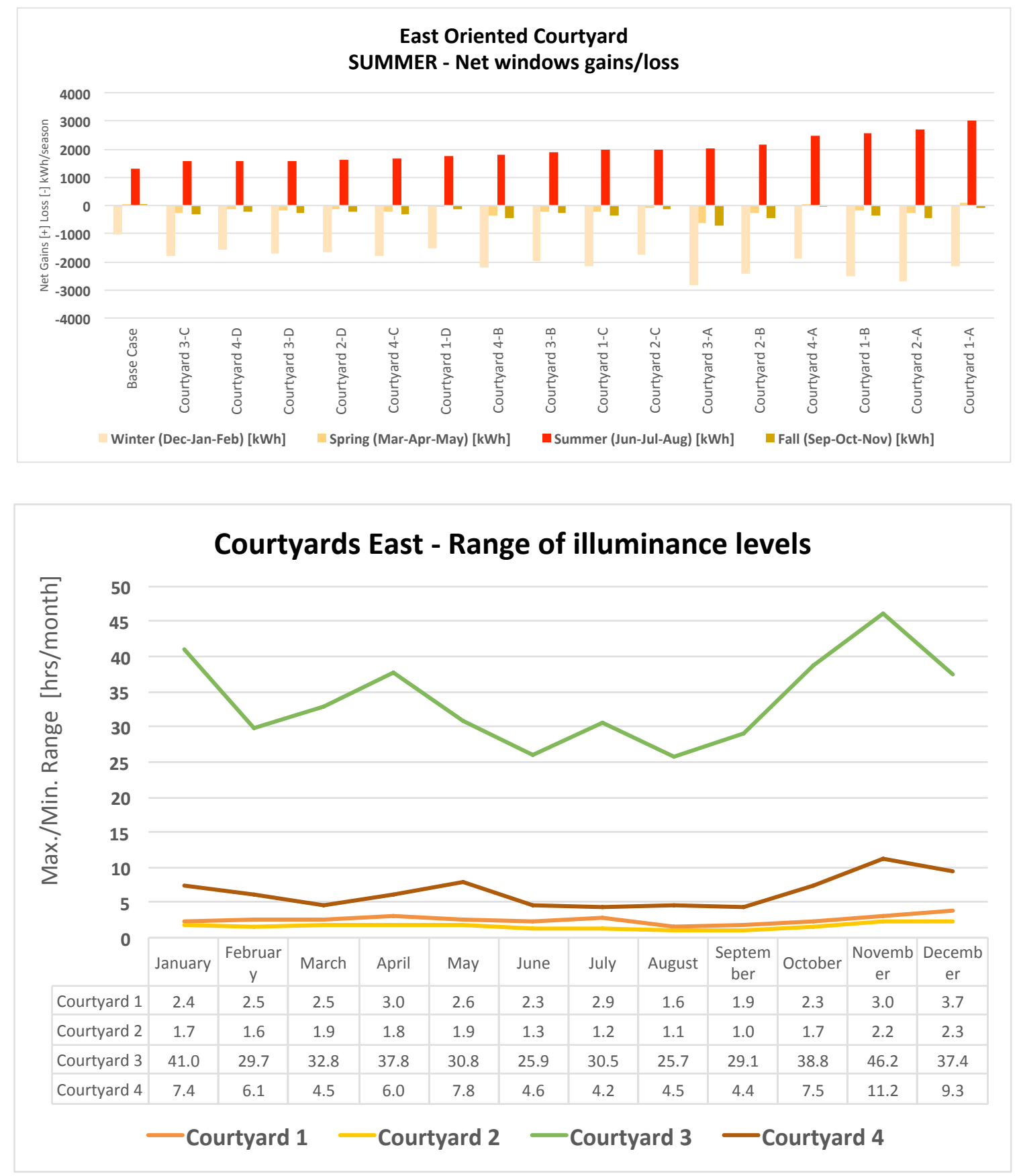


\section{Appendix B - East Orientation Results}

\begin{tabular}{|c|c|c|c|c|c|}
\hline & $\begin{array}{l}\text { Priority scale } 1 \\
\text { Illuminance best } 8\end{array}$ & Natural gas best 4 & Electricity best 2 & & \\
\hline & 1st & 2nd & $3 r d$ & 4th & \\
\hline & Courtyard 2-D & Courtyard 1-D & Courtyard 2-C & Courtyard 1-A & \\
\hline Electricity [kWh] & 4106 & 4139 & 4244 & & 4628 \\
\hline Natural Gas [eKwh] & 14903 & 14825 & 15017 & & 15256 \\
\hline Energy use increase compared to base case & $18.49 \%$ & $18.22 \%$ & $20.07 \%$ & & $23.95 \%$ \\
\hline Electricity Cost [\$] & $\$ 876$ & $\$ 883$ & $\$ 906$ & & $\$ 987$ \\
\hline Natural Gas Cost [\$] & $\$ 1,055$ & $\$ 1,051$ & $\$ 1,061$ & & $\$ 1,073$ \\
\hline Utility Cost Increase compared to base case & $9.27 \%$ & $9.45 \%$ & $11.28 \%$ & & $16.59 \%$ \\
\hline Illuminance over 100lux [hrs/yr] & 4187 & 4219 & 4188 & & 4250 \\
\hline \multirow[t]{4}{*}{ More hours than base case [hrs/yr] } & 616 & 648 & 616 & & 679 \\
\hline & $\begin{array}{l}\text { Priority scale } 2 \\
\text { Illuminance best } 8\end{array}$ & Electricity best 4 & Natural gas Best 2 & & \\
\hline & 1 st & 2nd & 3 rd & 4th & \\
\hline & Courtyard 1-D & Courtyard 2-D & Courtyard 2-C & Courtyard 1-C & \\
\hline Electricity [kWh] & 4139 & 4106 & 4244 & & 4256 \\
\hline Natural Gas [eKwh] & 14825 & 14903 & 15017 & & 16106 \\
\hline Energy use increase compared to base case & $18.22 \%$ & $18.49 \%$ & $20.07 \%$ & & $26.93 \%$ \\
\hline Electricity Cost [\$] & $\$ 883$ & $\$ 876$ & $\$ 906$ & & $\$ 908$ \\
\hline Natural Gas Cost [\$] & $\$ 1,051$ & $\$ 1,055$ & $\$ 1,061$ & & $\$ 1,116$ \\
\hline Utility Cost Increase compared to base case & $9.45 \%$ & $9.27 \%$ & $11.28 \%$ & & $14.54 \%$ \\
\hline Illuminance over 100lux [hrs/yr] & 4219 & 4187 & 4188 & & 4222 \\
\hline \multirow[t]{5}{*}{ More hours than base case [hrs/yr] } & 648 & 616 & 616 & & 651 \\
\hline & Priority scale 3 & & & & \\
\hline & Natural gas best 8 & Electricity best 4 & Illuminance best 2 & & \\
\hline & 1st & & & 4th & \\
\hline & Courtyard 2-D & Courtyard 4-D & Courtyard 3-C & Courtyard 3-D & \\
\hline Electricity [kWh] & 4106 & 4092 & 4100 & & 4103 \\
\hline Natural Gas [eKwh] & 14903 & 14456 & 14719 & & 14519 \\
\hline Energy use increase compared to base case & $18.49 \%$ & $15.62 \%$ & $17.32 \%$ & & $16.09 \%$ \\
\hline Electricity Cost [\$] & $\$ 876$ & $\$ 873$ & $\$ 875$ & & $\$ 875$ \\
\hline Natural Gas Cost [\$] & $\$ 1,055$ & $\$ 1,032$ & $\$ 1,046$ & & $\$ 1,036$ \\
\hline Utility Cost Increase compared to base case & $9.27 \%$ & $7.82 \%$ & $8.68 \%$ & & $8.14 \%$ \\
\hline Illuminance over 100lux [hrs/yr] & 4187 & 3996 & 3566 & & 3566 \\
\hline \multirow[t]{5}{*}{ More hours than base case [hrs/yr] } & 616 & 425 & -5 & & \\
\hline & Priority scale 4 & & & & \\
\hline & Natural gas best 8 & Illuminance best 4 & Electricity best 2 & & \\
\hline & & & $3 \mathrm{rd}$ & 4 th & \\
\hline & Courtyard 2-D & Courtyard 1-D & Courtyard 2-C & Courtyard 4-A & \\
\hline Electricity [kWh] & 4106 & 4139 & 4244 & & 4439 \\
\hline Natural Gas [eKwh] & 14903 & 14825 & 15017 & & 14981 \\
\hline Energy use increase compared to base case & $18.49 \%$ & $18.22 \%$ & $20.07 \%$ & & $21.06 \%$ \\
\hline Electricity Cost [\$] & $\$ 876$ & $\$ 883$ & $\$ 906$ & & $\$ 947$ \\
\hline Natural Gas Cost [\$] & $\$ 1,055$ & $\$ 1,051$ & $\$ 1,061$ & & $\$ 1,059$ \\
\hline Utility Cost Increase compared to base case & $9.27 \%$ & $9.45 \%$ & $11.28 \%$ & & $13.52 \%$ \\
\hline Illuminance over 100lux [hrs/yr] & 4187 & 4219 & 4188 & & 4074 \\
\hline \multirow[t]{5}{*}{ More hours than base case $[\mathrm{hrs} / \mathrm{yr}]$} & 616 & 648 & 616 & & 503 \\
\hline & Priority scale 5 & & & & \\
\hline & Electricity best 8 & Natural gas best 4 & Illuminance best 2 & & \\
\hline & 1 st & 2nd & $3 r d$ & 4th & \\
\hline & Courtyard 1-D & Courtyard 4-D & Courtyard 3-C & Courtyard 3-D & \\
\hline Electricity [kWh] & 4139 & 4092 & 4100 & & 4103 \\
\hline Natural Gas [eKwh] & 14825 & 14456 & 14719 & & 14519 \\
\hline Energy use increase compared to base case & $18.22 \%$ & $15.62 \%$ & $17.32 \%$ & & $16.09 \%$ \\
\hline Electricity Cost [\$\$ $]$ & $\$ 883$ & $\$ 873$ & $\$ 875$ & & $\$ 875$ \\
\hline Natural Gas Cost [\$] & $\$ 1,051$ & $\$ 1,032$ & $\$ 1,046$ & & $\$ 1,036$ \\
\hline Utility Cost Increase compared to base case & $9.45 \%$ & $7.82 \%$ & $8.68 \%$ & & $8.14 \%$ \\
\hline Illuminance over 100lux [hrs/yr] & 4219 & 3996 & 3566 & & 3566 \\
\hline \multirow[t]{4}{*}{ More hours than base case $[\mathrm{hrs} / \mathrm{yr}]$} & 648 & 425 & -5 & & -5 \\
\hline & $\begin{array}{l}\text { Priority scale } 6 \\
\text { Electricity best } 8\end{array}$ & Illuminance best 4 & Natural gas best 2 & & \\
\hline & 1 st & 2nd & 3rd & 4th & \\
\hline & Courtyard 1-D & Courtyard 4-C & Courtyard 2-D & Courtyard 4-B & \\
\hline Electricity [kWh] & 4139 & 4136 & 4106 & & 4214 \\
\hline Natural Gas [eKwh] & 14825 & 14869 & 14903 & & 15656 \\
\hline Energy use increase compared to base case & $18.22 \%$ & $18.48 \%$ & $18.49 \%$ & & $23.86 \%$ \\
\hline Electricity Cost [\$] & $\$ 883$ & $\$ 882$ & $\$ 876$ & & $\$ 899$ \\
\hline Natural Gas Cost [\$] & $\$ 1,051$ & $\$ 1,053$ & $\$ 1,055$ & & $\$ 1,093$ \\
\hline Utility Cost Increase compared to base case & $9.45 \%$ & $9.55 \%$ & $9.27 \%$ & & $12.75 \%$ \\
\hline Illuminance over 100lux [hrs/yr] & 4219 & 3997 & 4187 & & 4074 \\
\hline More hours than base case $[\mathrm{hrs} / \mathrm{yr}]$ & 648 & 426 & 616 & & 502 \\
\hline
\end{tabular}




\section{Appendix B - East Orientation Results - Courtyard 1 EAST}
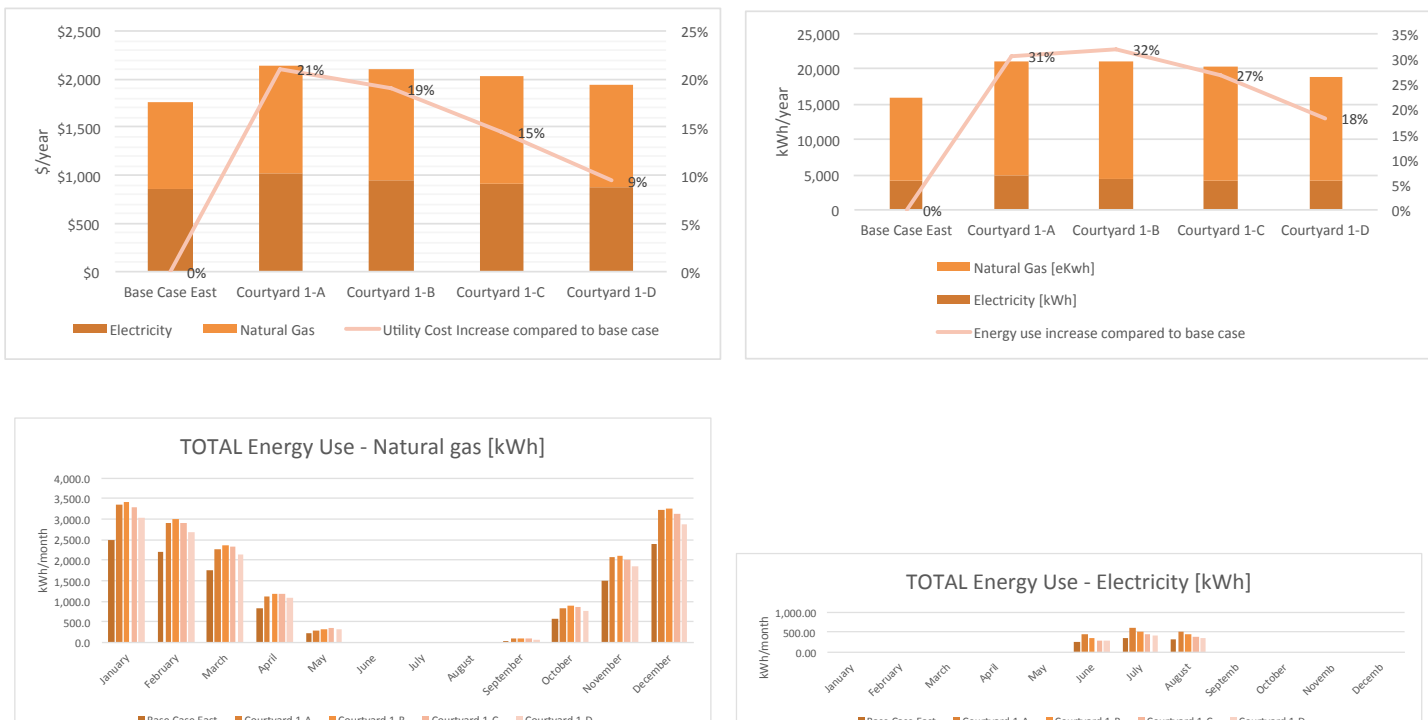

- Base Case East $=$ Courtyard 1-A $=$ Courtyard 1-B ECourtyard 1-C ECourtyard 1-D

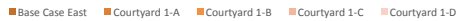

Hours per month of illuminance levels above 100lux at Sensor 1 (Centre)

Percentage of energy savings from overall electrical use
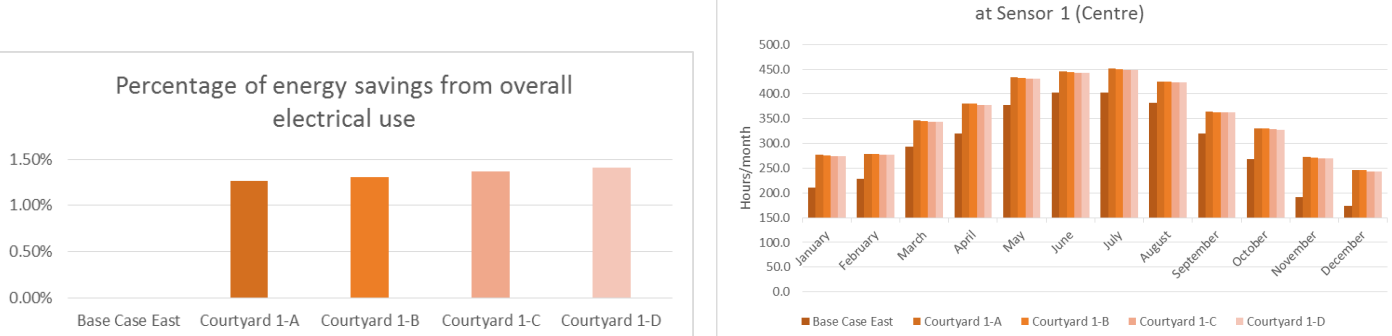

Range of extra hours between max. and min. window to wall ratio
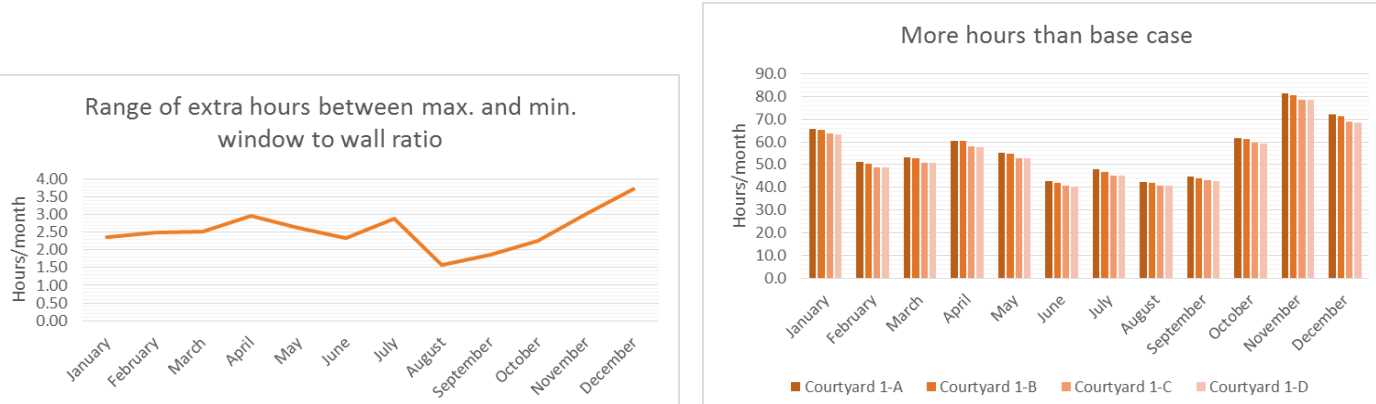


\section{Appendix B - East Orientation Results - Courtyard 2 EAST}
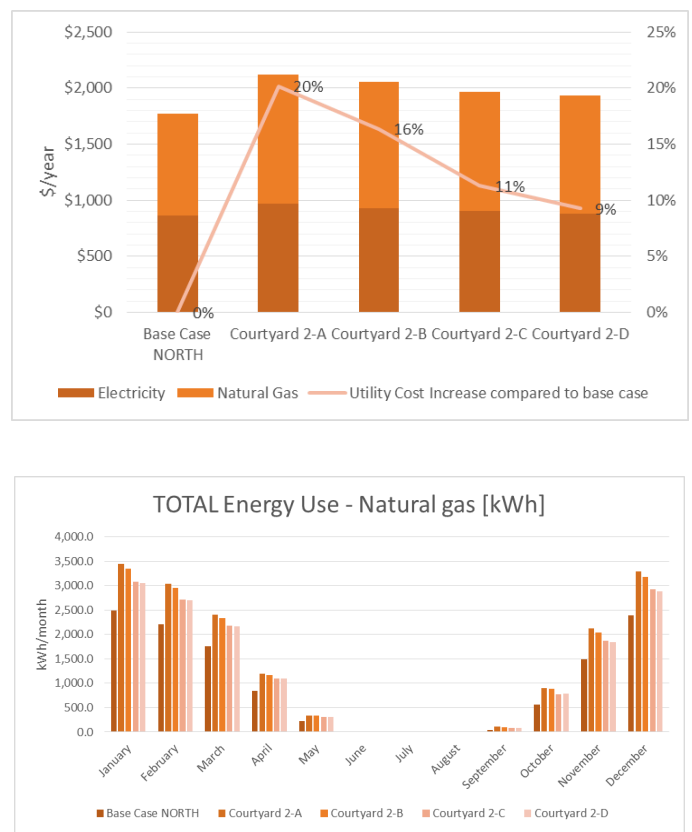

Percentage of energy savings from overall electrical use

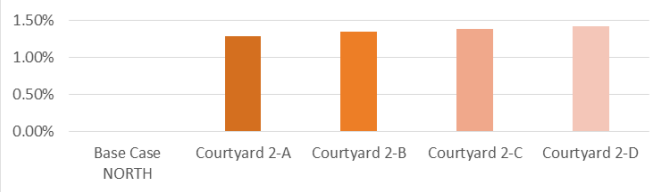

Range of extra hours between max. and min. window to wall ratio

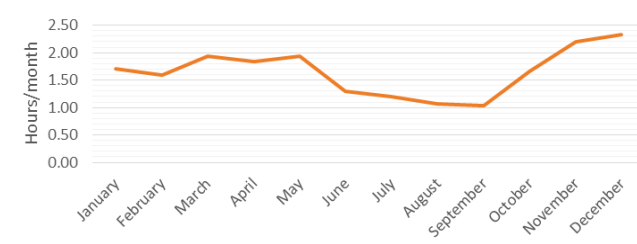

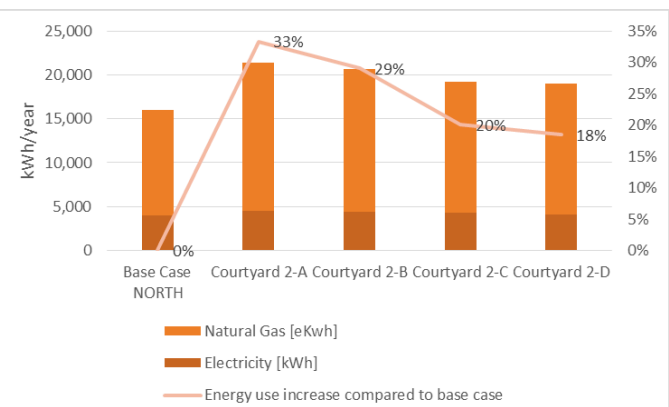

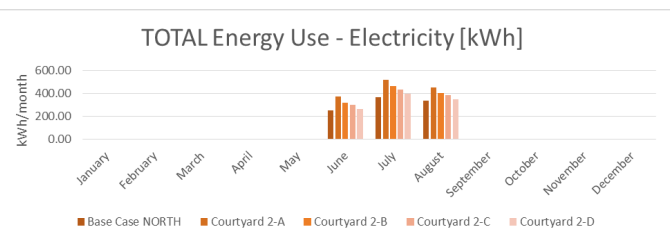
at Sensor 1 (Centre)
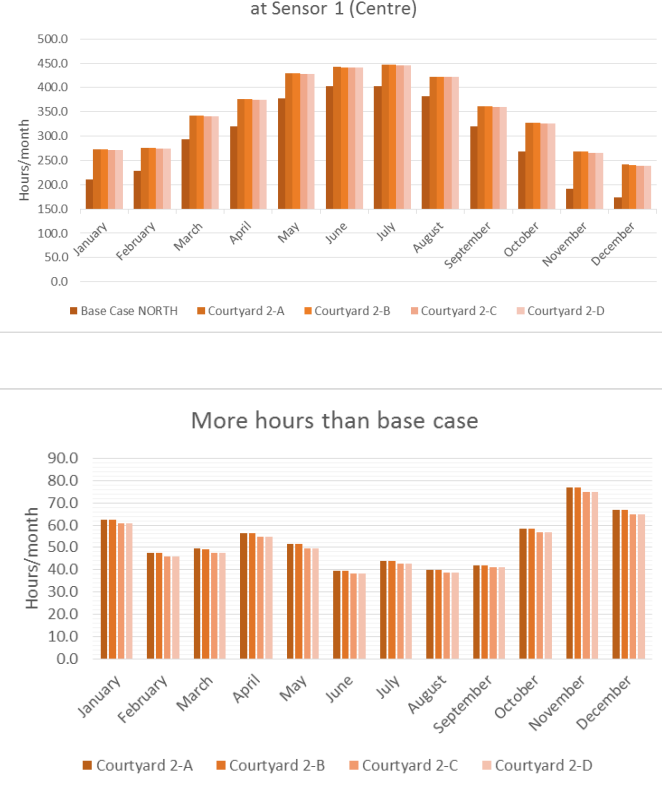


\section{Appendix B - East Orientation Results - Courtyard 3 EAST}
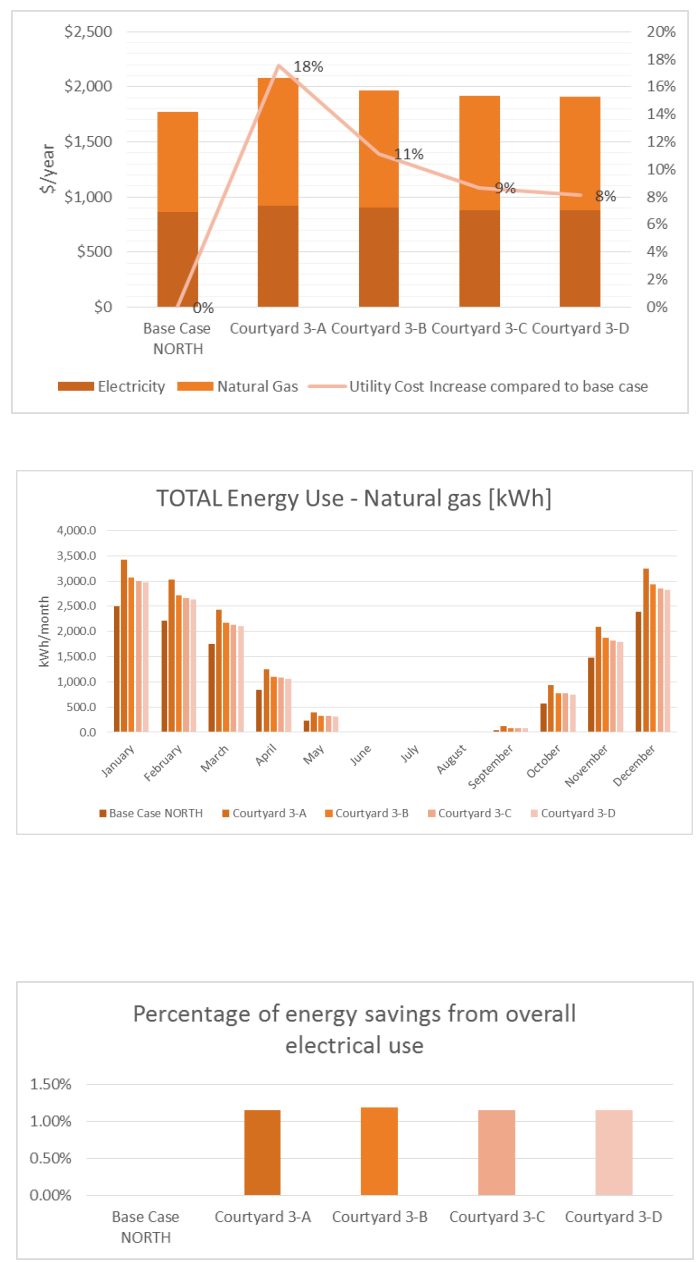

Range of extra hours between max. and $\mathrm{min}$ window to wall ratio

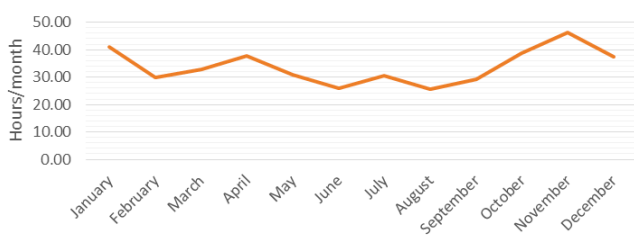

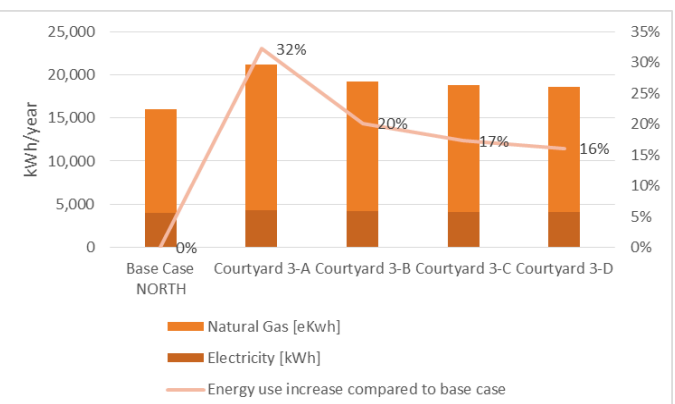

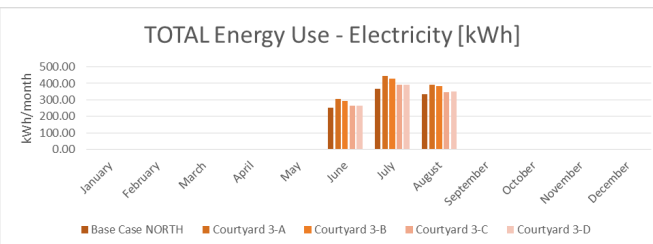

Hours per month of illuminance levels above 100 lux at Sensor 1 (Centre)

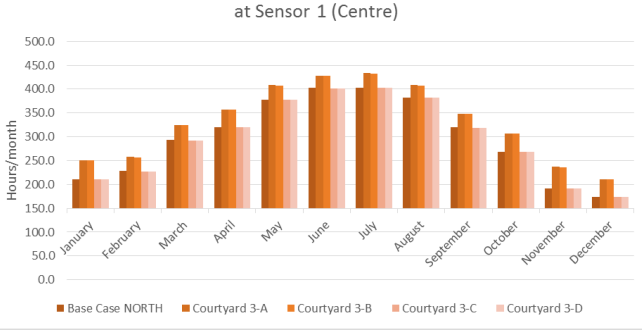

More hours than base case

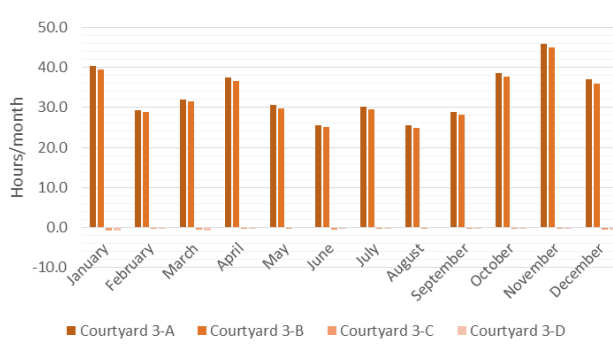


Appendix B - East Orientation Results - Courtyard 4 EAST
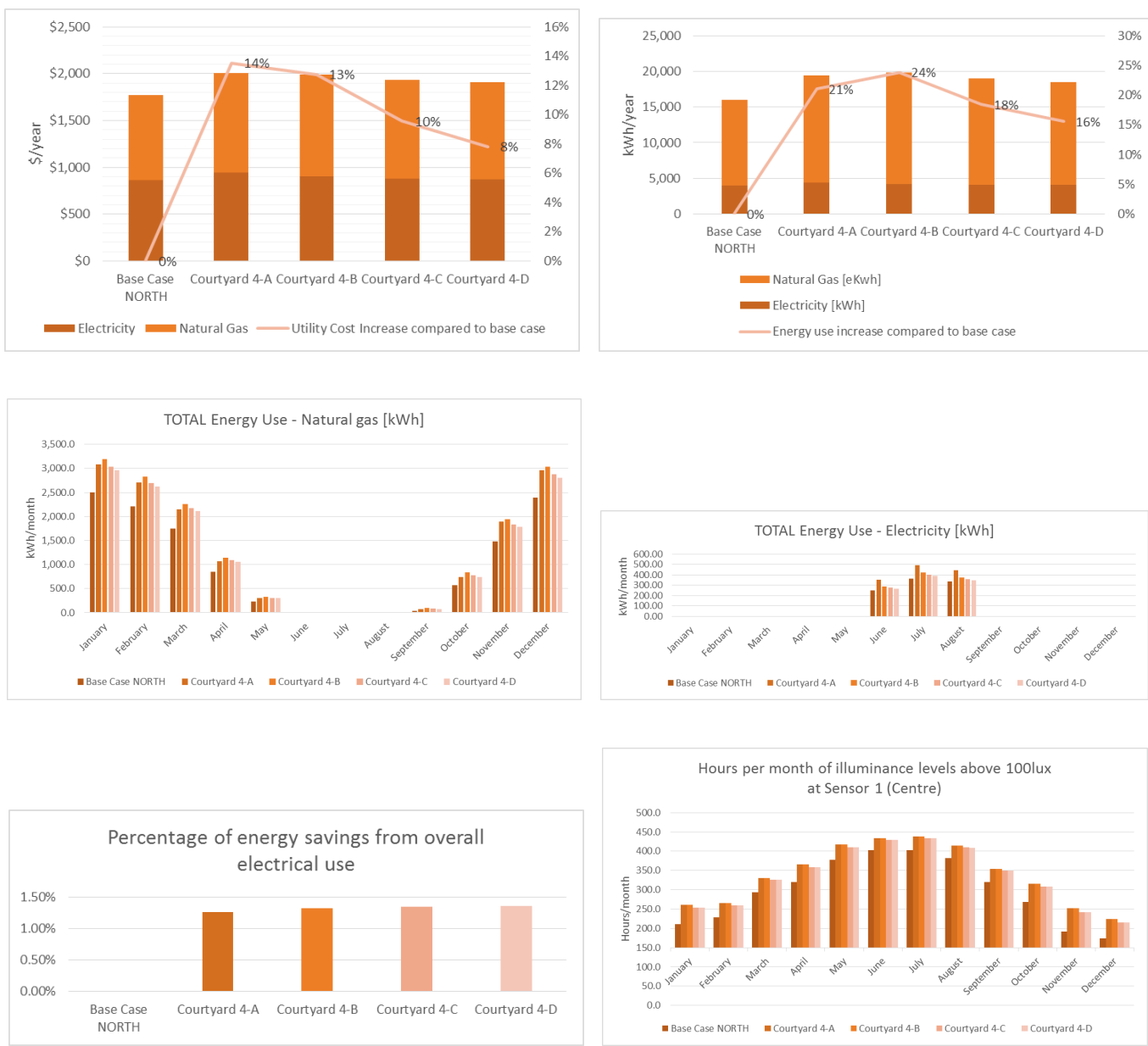

Range of extra hours between max. and min. window to wall ratio
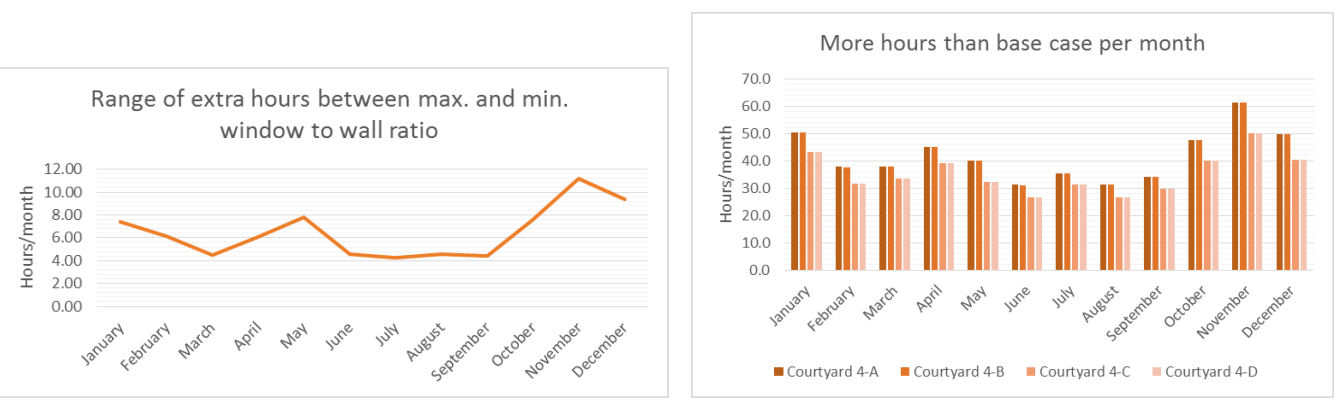


\section{Appendix C - North orientation results}

\begin{tabular}{|c|c|c|c|c|c|c|c|c|c|}
\hline \multicolumn{10}{|c|}{ NORTH Orientation chart } \\
\hline \multirow{4}{*}{\multicolumn{2}{|c|}{$\begin{array}{c}\text { Courtyard \#1 } \\
\text { Rectangle 1:1.5 }\end{array}$}} & & & \multirow{4}{*}{\multicolumn{2}{|c|}{$\begin{array}{l}\text { Courtyard \#3 } \\
\text { Rectangle 1:2 }\end{array}$}} & \multirow{4}{*}{\multicolumn{2}{|c|}{$\begin{array}{c}\text { Courtyard \#4 } \\
\text { Rectangle 2:1 }\end{array}$}} & \multicolumn{2}{|c|}{ NORTH BASE CASE } \\
\hline & & & & & & & & $\begin{array}{c}\text { Illuminance } \\
\text { [hrs/yr] }\end{array}$ & 3661 \\
\hline & & \multirow{2}{*}{$\begin{array}{l}\text { Courtyard } \# 2 \\
\text { Squared } \\
\end{array}$} & & & & & & $\begin{array}{l}\text { Nat. gas } \\
{[\mathrm{kWh} / \mathrm{yr}]}\end{array}$ & 12053 \\
\hline & & & & & & & & $\begin{array}{l}\text { Electricity } \\
{[\mathrm{kWh} / \mathrm{yr}]}\end{array}$ & 4564 \\
\hline 4217 & $15.18 \%$ & 4217 & $15.20 \%$ & 3997 & $9.18 \%$ & 4092 & $11.78 \%$ & $\begin{array}{l}\text { Illuminance } \\
\text { [hrs/yr] }\end{array}$ & \multirow{3}{*}{$\begin{array}{c}\text { Window to Wall } \\
\text { Ratio } A: 75 \%- \\
100 \%\end{array}$} \\
\hline 17114 & \multirow{2}{*}{$33.52 \%$} & 17083 & \multirow{2}{*}{$33.35 \%$} & 17275 & \multirow{2}{*}{$32.78 \%$} & 15597 & \multirow{2}{*}{$22.40 \%$} & $\begin{array}{l}\text { Nat. gas } \\
\text { [kWh/vr }\end{array}$ & \\
\hline 5072 & & 5075 & & 4789 & & 4742 & & $\begin{array}{l}\text { Electricity } \\
{[\mathrm{kWh} / \mathrm{yr}]}\end{array}$ & \\
\hline 4252 & $16.14 \%$ & 4216 & $15.17 \%$ & 3990 & $8.98 \%$ & 4022 & $9.87 \%$ & Illuminance & \multirow{3}{*}{$\begin{array}{c}\text { Window to Wall } \\
\text { Ratio B: } 55 \% \text { - } \\
\quad 65 \%\end{array}$} \\
\hline 16939 & \multirow{2}{*}{$32.11 \%$} & 16864 & \multirow{2}{*}{$30.17 \%$} & 15303 & \multirow{2}{*}{$20.86 \%$} & 14686 & \multirow{2}{*}{$16.62 \%$} & Nat. gas & \\
\hline 5014 & & 4767 & & 4781 & & 4692 & & $\begin{array}{l}\text { Electricity } \\
\text { [kWh/yr] }\end{array}$ & \\
\hline 4233 & $15.62 \%$ & 4199 & $14.71 \%$ & 3657 & $-0.10 \%$ & 4022 & $9.86 \%$ & Illuminance & \multirow{3}{*}{$\begin{array}{l}\text { Window to Wall } \\
\text { Ratio C: } 35 \%- \\
\quad 45 \%\end{array}$} \\
\hline 16333 & \multirow{2}{*}{$26.91 \%$} & 15653 & \multirow{2}{*}{$22.68 \%$} & 14836 & \multirow{2}{*}{$17.24 \%$} & 14339 & \multirow{2}{*}{$14.09 \%$} & Nat. gas & \\
\hline 4756 & & 4733 & & 4644 & & 4619 & & $\begin{array}{l}\text { Electricity } \\
{[\mathrm{kWh} / \mathrm{r}]}\end{array}$ & \\
\hline 4230 & $15.54 \%$ & 4199 & $14.70 \%$ & 3656 & $-0.13 \%$ & 4022 & $9.86 \%$ & $\begin{array}{l}\text { Illuminance } \\
\text { [hrs/yr] }\end{array}$ & \multirow{3}{*}{$\begin{array}{l}\text { Window to Wall } \\
\text { Ratio D: } 20 \%- \\
35 \%\end{array}$} \\
\hline 15244 & \multirow{2}{*}{$19.53 \%$} & 15008 & \multirow{2}{*}{$18.07 \%$} & 14733 & & 14339 & & $\begin{array}{l}\text { Nat. gas } \\
\text { [kWh/vr }\end{array}$ & \\
\hline 4617 & & 4611 & & 4581 & $10.23 \%$ & 4619 & $14.09 \%$ & Electricity & \\
\hline
\end{tabular}

*Highlighted options correspond to the best performers in the priority scales

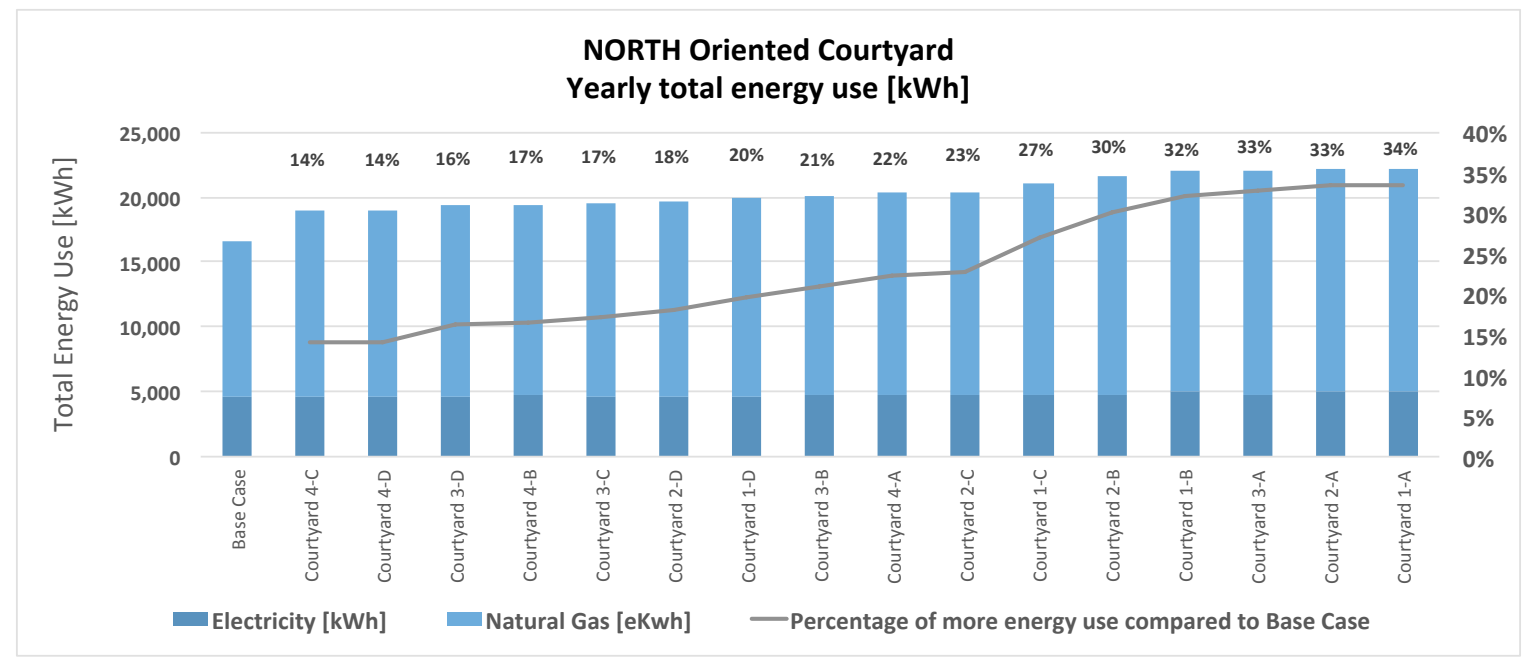



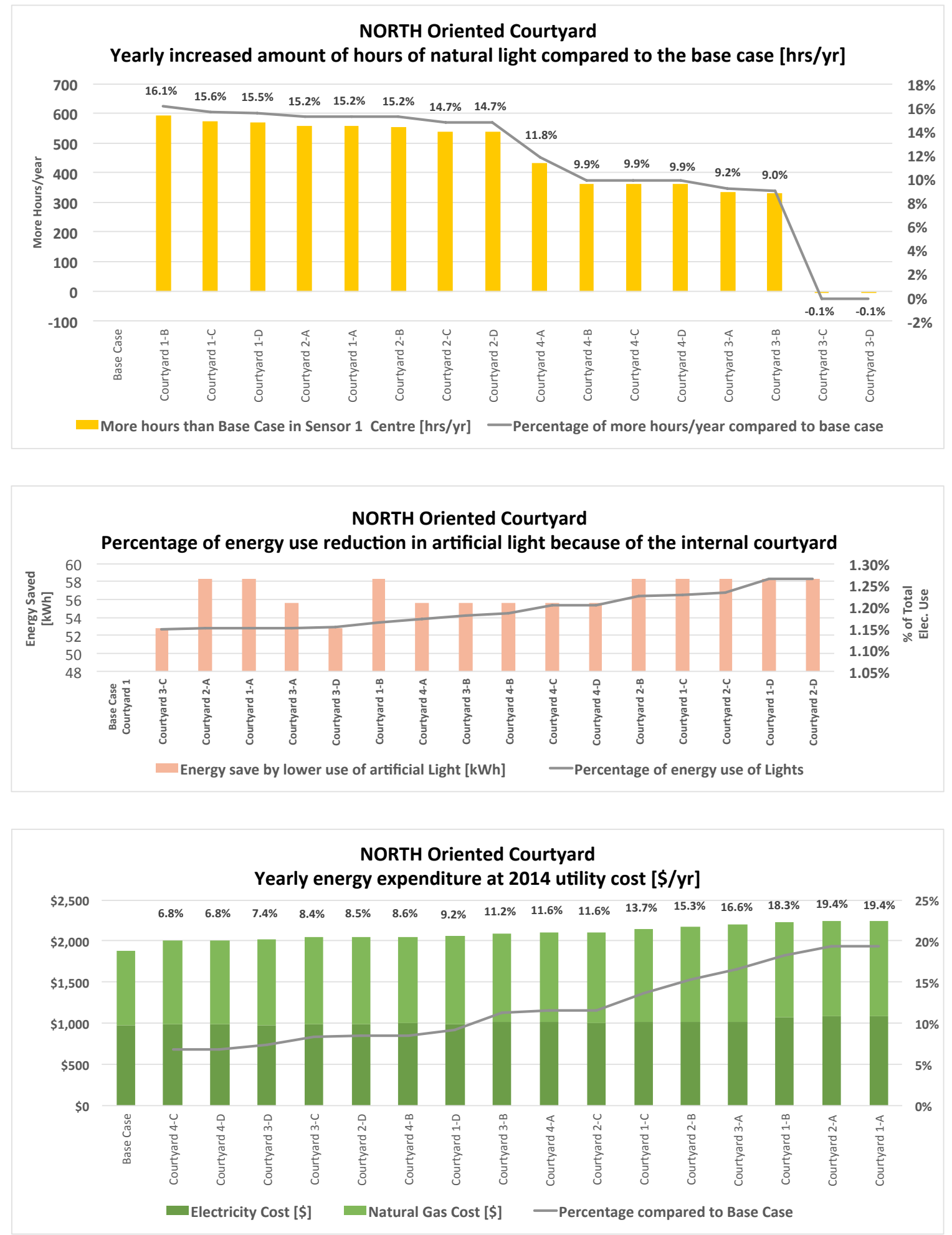
Appendix C - North Orientation Results
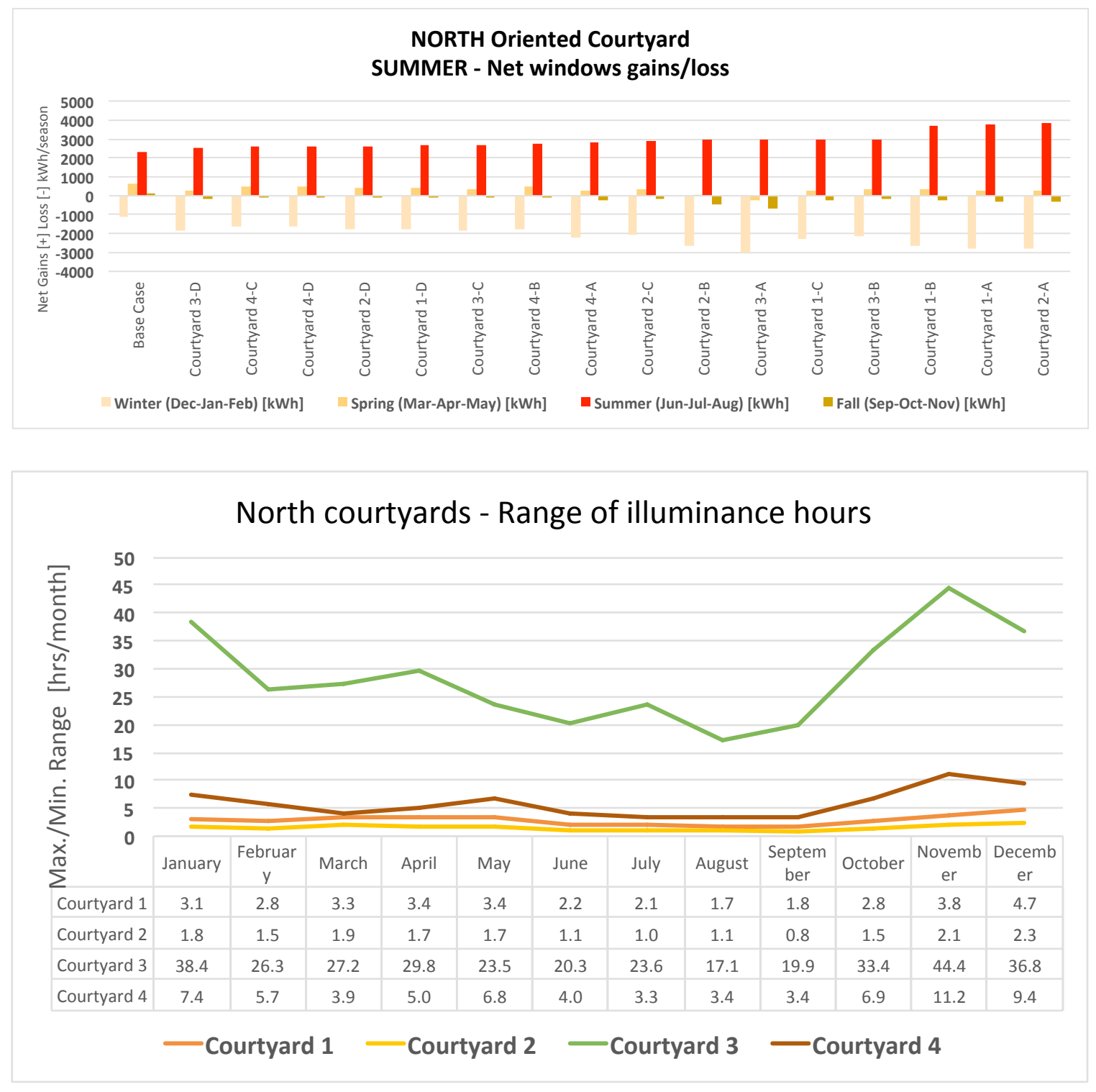


\section{Appendix C - North Orientation Results}

\begin{tabular}{|c|c|c|c|c|c|}
\hline & $\begin{array}{l}\text { Priority scale } 1 \\
\text { Illuminance best } 8\end{array}$ & Natural gas best 4 & Electricity best 2 & & \\
\hline & 1 st & 2nd & $3 r d$ & 4th & \\
\hline & Courtyard 2-D & Courtyard 1-D & Courtyard 2-C & Courtyard 1-C & \\
\hline Electricity [kWh] & 4611 & 4617 & 4733 & & 4756 \\
\hline Natural Gas [eKwh] & 15008 & 15244 & 15653 & & 16333 \\
\hline Energy use increase compared to base case & $18.07 \%$ & $19.53 \%$ & $22.68 \%$ & & $26.91 \%$ \\
\hline Electricity Cost [\$] & $\$ 984$ & $\$ 985$ & $\$ 1,010$ & & $\$ 1,015$ \\
\hline Natural Gas Cost [\$] & $\$ 1,060$ & $\$ 1,072$ & $\$ 1,093$ & & $\$ 1,128$ \\
\hline Utility Cost Increase compared to base case & $8.51 \%$ & $9.21 \%$ & $11.63 \%$ & & $13.72 \%$ \\
\hline Illuminance over 100lux [hrs/yr] & 4199 & 4230 & 4199 & & 4233 \\
\hline \multirow[t]{5}{*}{ More hours than base case [hrs/yr] } & 538 & 569 & 539 & & 572 \\
\hline & Priority scale 2 & & & & \\
\hline & Illuminance best 8 & Electricity best 4 & Natural gas Best 2 & & \\
\hline & 1st & 2nd & $3 r d$ & 4th & \\
\hline & Courtyard 2-D & Courtyard 1-D & Courtyard 2-C & Courtyard 1-C & \\
\hline Electricity [kWh] & 4611 & 4617 & 4733 & & 4756 \\
\hline Natural Gas [eKwh] & 15008 & 15244 & 15653 & & 16333 \\
\hline Energy use increase compared to base case & $18.07 \%$ & $19.53 \%$ & $22.68 \%$ & & $26.91 \%$ \\
\hline Electricity Cost [\$] & $\$ 984$ & $\$ 985$ & $\$ 1,010$ & & $\$ 1,015$ \\
\hline Natural Gas Cost [\$] & $\$ 1,060$ & $\$ 1,072$ & $\$ 1,093$ & & $\$ 1,128$ \\
\hline Utility Cost Increase compared to base case & $8.51 \%$ & $9.21 \%$ & $11.63 \%$ & & $13.72 \%$ \\
\hline Illuminance over 100lux [hrs/yr] & 4199 & 4230 & 4199 & & 4233 \\
\hline \multirow[t]{5}{*}{ More hours than base case [hrs/yr] } & 538 & 569 & 539 & & 572 \\
\hline & Priority scale 3 & & & & \\
\hline & Natural gas best 8 & Electricity best 4 & Illuminance best 2 & & \\
\hline & $1 \mathrm{st}$ & 2nd & $3 \mathrm{rd}$ & 4th & \\
\hline & Courtyard 1-D & Courtyard 2-D & Courtyard 4-C & Courtyard 3-D & \\
\hline Electricity [kWh] & 4617 & 4611 & 4619 & & 4581 \\
\hline Natural Gas [eKwh] & 15244 & 15008 & 14339 & & 14733 \\
\hline Energy use increase compared to base case & $19.53 \%$ & $18.07 \%$ & $14.09 \%$ & & $16.23 \%$ \\
\hline Electricity Cost [\$] & $\$ 985$ & $\$ 984$ & $\$ 986$ & & $\$ 977$ \\
\hline Natural Gas Cost [\$] & $\$ 1,072$ & $\$ 1,060$ & $\$ 1,026$ & & $\$ 1,046$ \\
\hline Utility Cost Increase compared to base case & $9.21 \%$ & $8.51 \%$ & $6.80 \%$ & & $7.42 \%$ \\
\hline Illuminance over 100lux [hrs/yr] & 4230 & 4199 & 4022 & & 3656 \\
\hline \multirow[t]{5}{*}{ More hours than base case [hrs/yr] } & 569 & 538 & 361 & & -5 \\
\hline & Priority scale 4 & & & & \\
\hline & Natural gas best 8 & Illuminance best 4 & Electricity best 2 & & \\
\hline & 1st & 2nd & $3 r d$ & 4th & \\
\hline & Courtyard 2-D & Courtyard 1-D & Courtyard 4-C & Courtyard 4-B & \\
\hline Electricity [kWh] & 4611 & 4617 & 4619 & & 4692 \\
\hline Natural Gas [eKwh] & 15008 & 15244 & 14339 & & 14686 \\
\hline Energy use increase compared to base case & $18.07 \%$ & $19.53 \%$ & $14.09 \%$ & & $16.62 \%$ \\
\hline Electricity Cost [\$\$] & $\$ 984$ & $\$ 985$ & $\$ 986$ & & $\$ 1,001$ \\
\hline Natural Gas Cost [\$] & $\$ 1,060$ & $\$ 1,072$ & $\$ 1,026$ & & $\$ 1,044$ \\
\hline Utility Cost Increase compared to base case & $8.51 \%$ & $9.21 \%$ & $6.80 \%$ & & $8.55 \%$ \\
\hline Illuminance over 100lux [hrs/yr] & 4199 & 4230 & 4022 & & 4022 \\
\hline \multirow[t]{5}{*}{ More hours than base case [hrs/yr] } & 538 & 569 & 361 & & 361 \\
\hline & Priority scale 5 & & & & \\
\hline & Electricity best 8 & Natural gas best 4 & Illuminance best 2 & & \\
\hline & 1 st & 2nd & 3rd & 4 th & \\
\hline & Courtyard 4-B & Courtyard 4-C & Courtyard 4-D & Courtyard 3-D & \\
\hline Electricity [kWh] & 4692 & 4619 & 4619 & & 4581 \\
\hline Natural Gas [eKwh] & 14686 & 14339 & 14339 & & 14733 \\
\hline Energy use increase compared to base case & $16.62 \%$ & $14.09 \%$ & $14.09 \%$ & & $16.23 \%$ \\
\hline Electricity Cost [\$] & $\$ 1,001$ & $\$ 986$ & $\$ 986$ & & $\$ 977$ \\
\hline Natural Gas Cost [\$] & $\$ 1,044$ & $\$ 1,026$ & $\$ 1,026$ & & $\$ 1,046$ \\
\hline Utility Cost Increase compared to base case & $8.55 \%$ & $6.80 \%$ & $6.80 \%$ & & $7.42 \%$ \\
\hline Illuminance over 100lux [hrs/yr] & 4022 & 4022 & 4022 & & 3656 \\
\hline \multirow[t]{5}{*}{ More hours than base case [hrs/yr] } & 361 & 361 & 361 & & -5 \\
\hline & Priority scale 6 & & & & \\
\hline & Electricity best 8 & Illuminance best 4 & Natural gas best 2 & & \\
\hline & 1st & 2nd & $3 \mathrm{rd}$ & 4th & \\
\hline & Courtyard 4-B & Courtyard 2-D & Courtyard 1-D & Courtyard 2-C & \\
\hline Electricity [kWh] & 4692 & 4611 & 4617 & & 4733 \\
\hline Natural Gas [eKwh] & 14686 & 15008 & 15244 & & 15653 \\
\hline Energy use increase compared to base case & $16.62 \%$ & $18.07 \%$ & $19.53 \%$ & & $22.68 \%$ \\
\hline Electricity Cost [\$] & $\$ 1,001$ & $\$ 984$ & $\$ 985$ & & $\$ 1,010$ \\
\hline Natural Gas Cost [\$] & $\$ 1,044$ & $\$ 1,060$ & $\$ 1,072$ & & $\$ 1,093$ \\
\hline Utility Cost Increase compared to base case & $8.55 \%$ & $8.51 \%$ & $9.21 \%$ & & $11.63 \%$ \\
\hline Illuminance over 100lux [hrs/yr] & 4022 & 4199 & 4230 & & 4199 \\
\hline More hours than base case [hrs/yr] & 361 & 538 & 569 & & 539 \\
\hline
\end{tabular}




\section{Appendix C - North Orientation Results - Courtyard 1 NORTH}
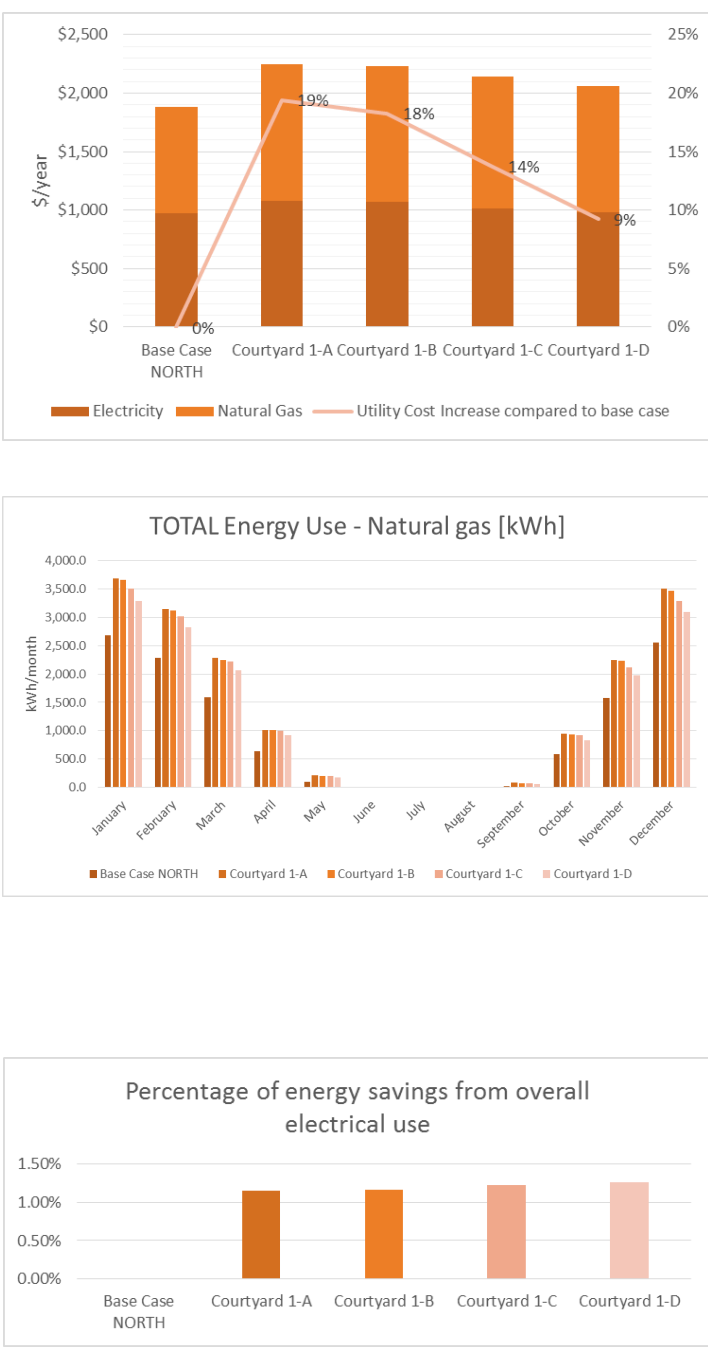

Range of extra hours between max. and min. window to wall ratio

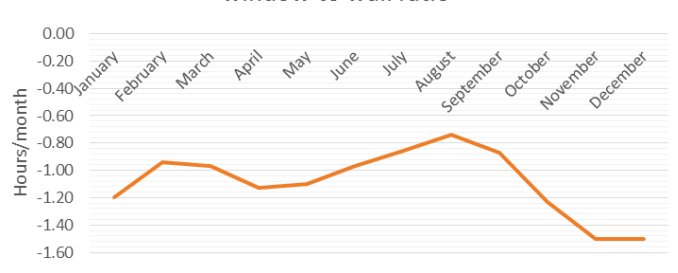

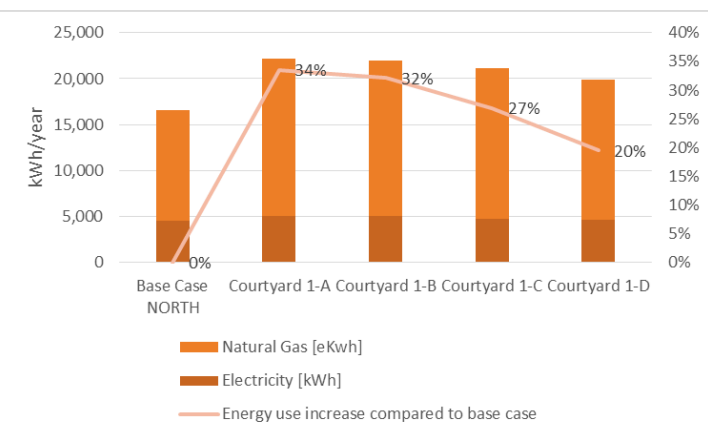
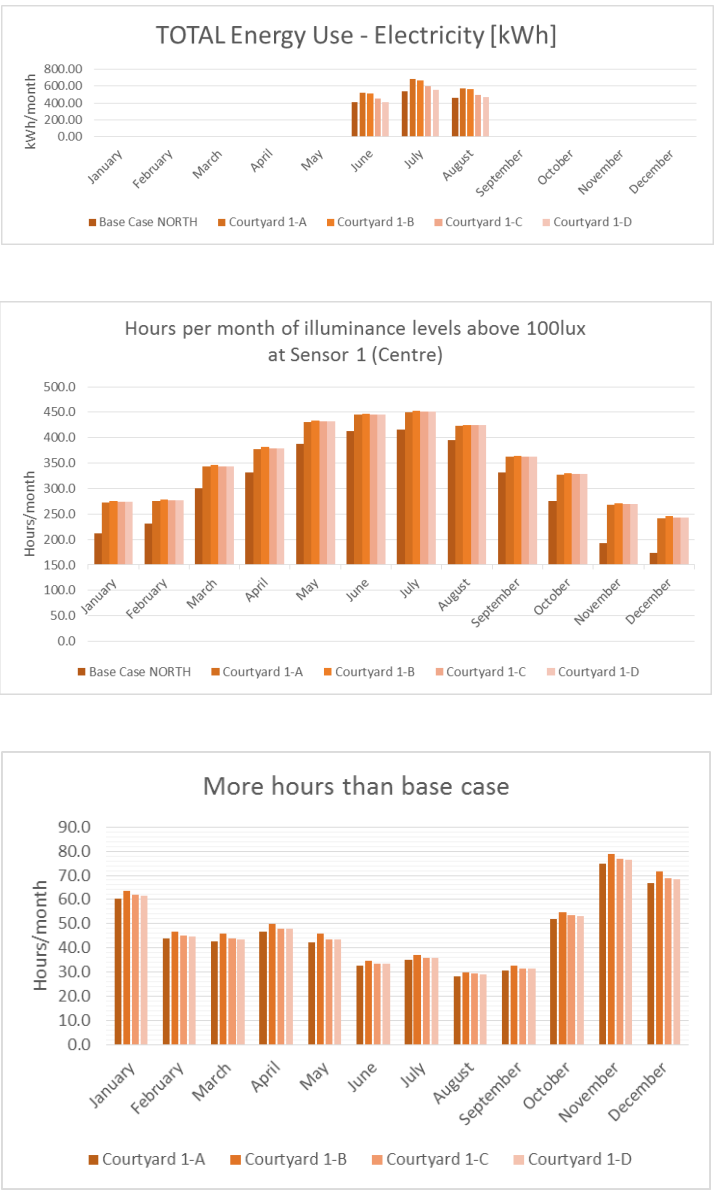


\section{Appendix C - North Orientation Results - Courtyard 2 NORTH}
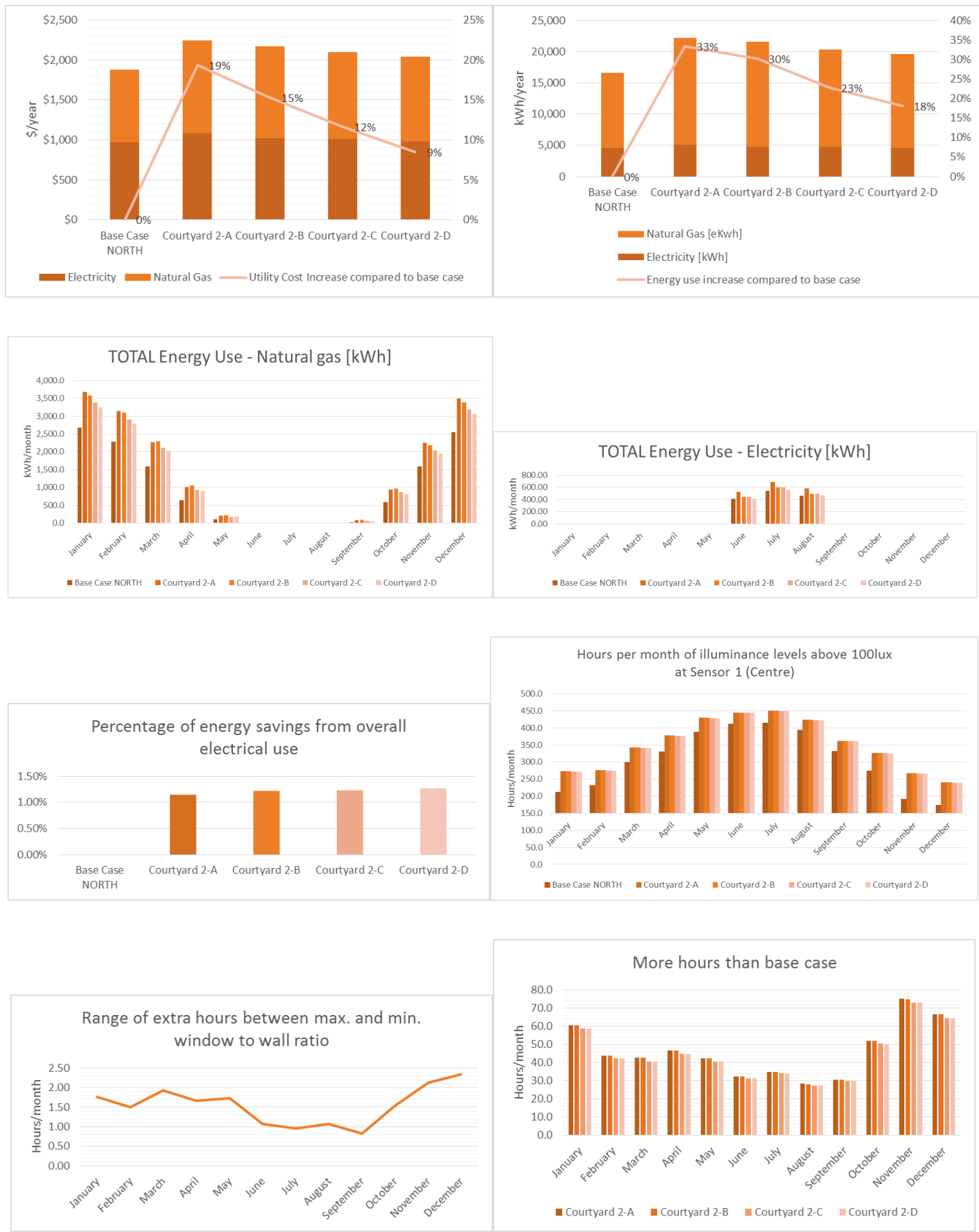


\section{Appendix C - North Orientation Results - Courtyard 3 NORTH}
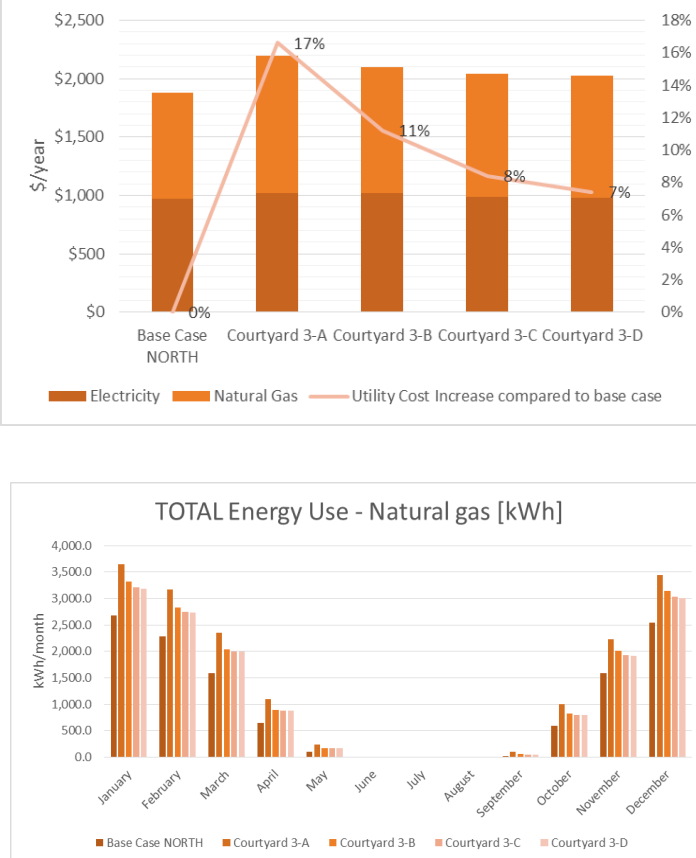

Percentage of energy savings from overall electrical use

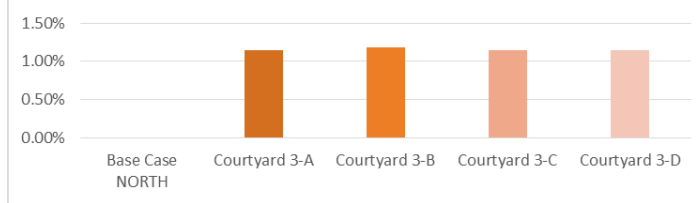

Range of extra hours between max. and min. window to wall ratio

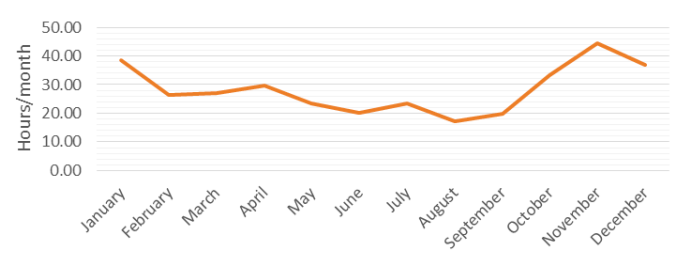

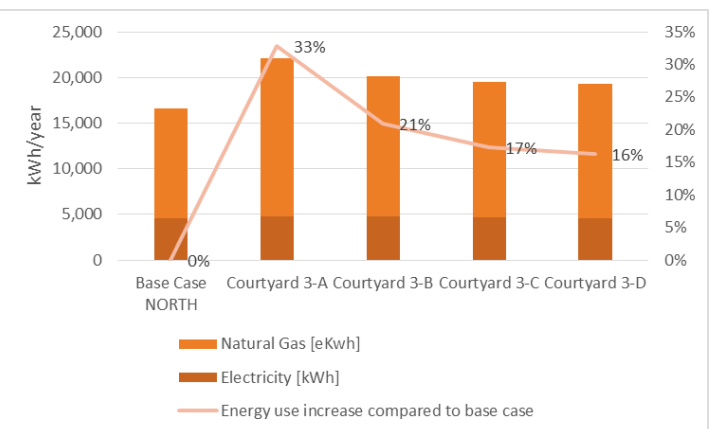

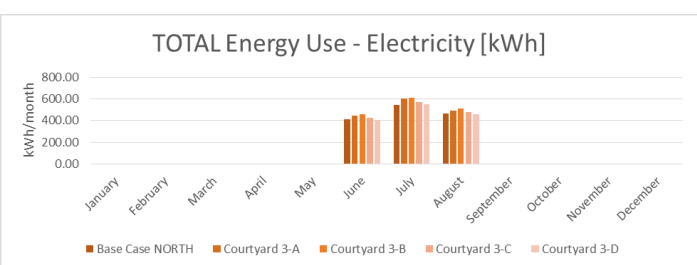

Hours per month of illuminance levels above 100 lux at Sensor 1 (Centre)

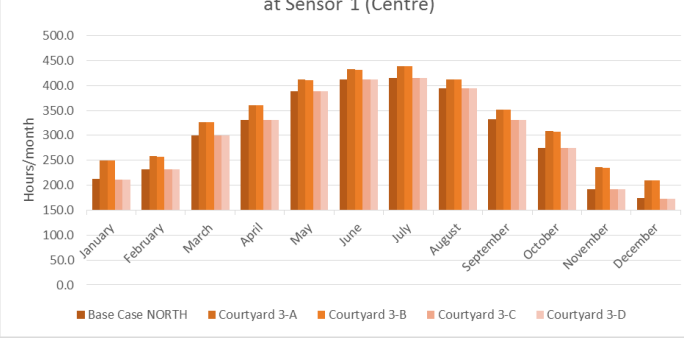

More hours than base case

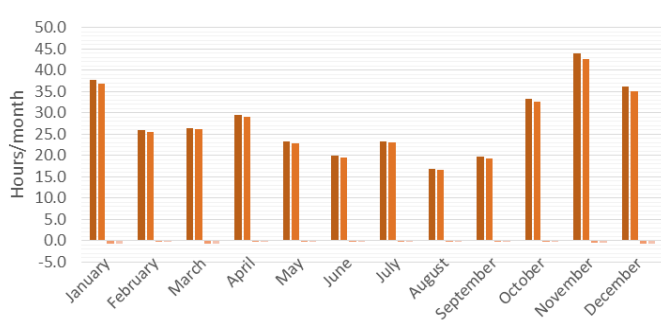

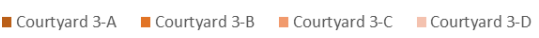




\section{Appendix C - North Orientation Results - Courtyard 4 NORTH}
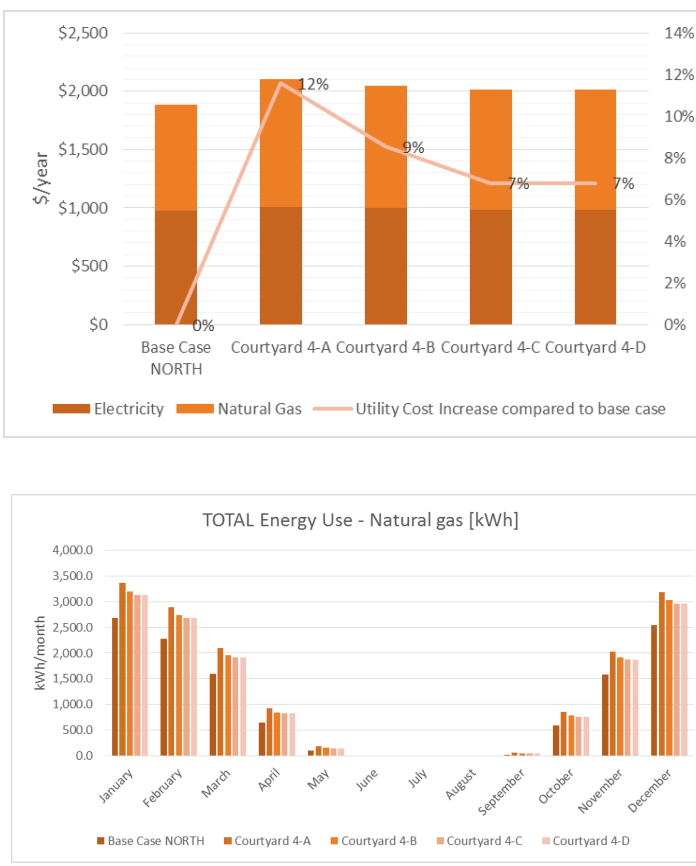
electrical use

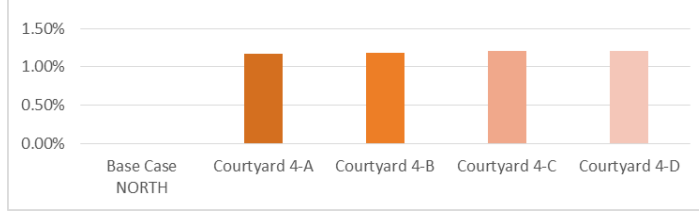

Range of extra hours between max. and min window to wall ratio

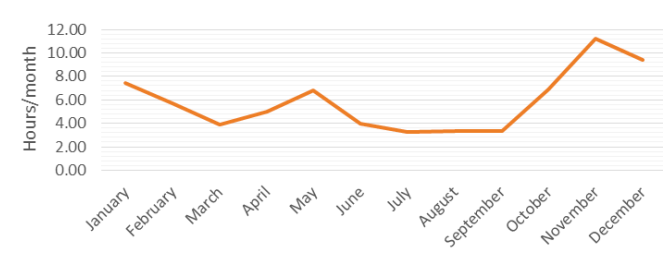

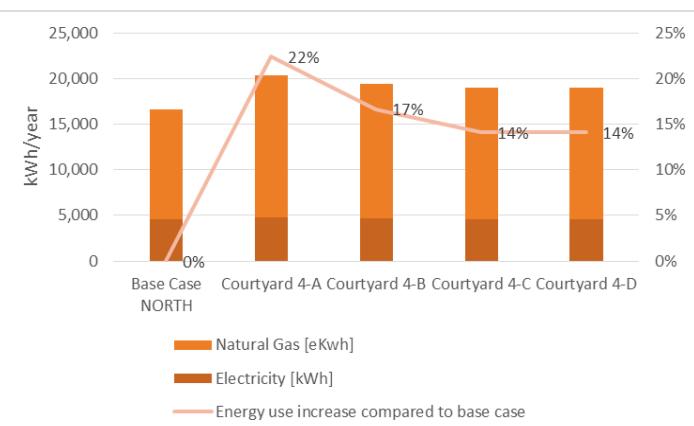

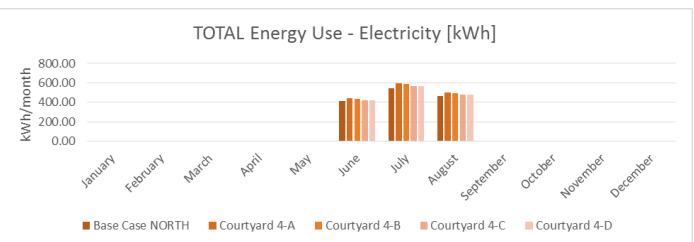

Hours per month of illuminance levels above 100 lux at Sensor 1 (Centre)

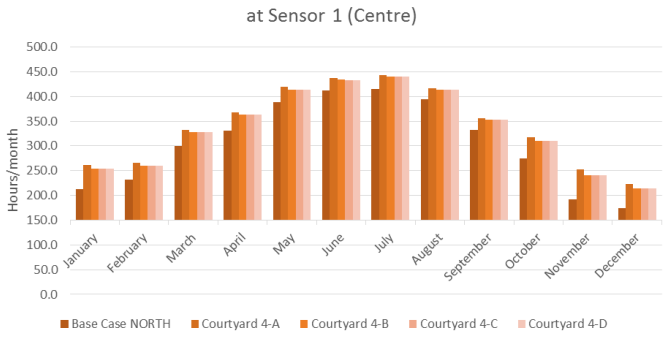

More hours than base case per month

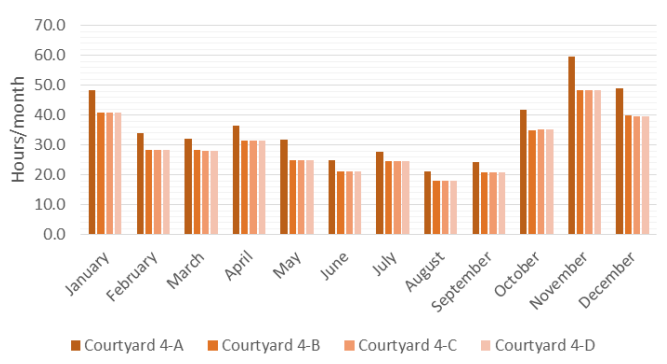




\section{Appendix D - West orientation results}

\begin{tabular}{|c|c|c|c|c|c|c|c|c|c|}
\hline \multicolumn{10}{|c|}{ West Orientation chart } \\
\hline \multirow{4}{*}{\multicolumn{2}{|c|}{$\begin{array}{c}\text { Courtyard \#1 } \\
\text { Rectangle 1:1.5 }\end{array}$}} & & & \multirow{4}{*}{\multicolumn{2}{|c|}{$\begin{array}{l}\text { Courtyard \#3 } \\
\text { Rectangle 1:2 }\end{array}$}} & \multirow{4}{*}{\multicolumn{2}{|c|}{$\begin{array}{l}\text { Courtyard \#4 } \\
\text { Rectangle 2:1 }\end{array}$}} & \multicolumn{2}{|c|}{ WEST BASE CASE } \\
\hline & & & & & & & & $\begin{array}{l}\text { Illuminance } \\
\text { [hrs/yr] }\end{array}$ & 3570 \\
\hline & & \multirow{2}{*}{$\begin{array}{l}\text { Courtyard \#2 } \\
\text { Squared } 1: 1\end{array}$} & & & & & & $\begin{array}{l}\text { Nat. gas } \\
\text { [kWh/yr] }\end{array}$ & 12417 \\
\hline & & & & & & & & $\begin{array}{l}\text { Electricity } \\
{[\mathrm{kWh} / \mathrm{yr}]}\end{array}$ & 4025 \\
\hline 4284 & $20.00 \%$ & 4213 & $18.01 \%$ & 3969 & $11.19 \%$ & 4072 & $14.05 \%$ & $\begin{array}{l}\text { Illuminance } \\
\text { [hrs/yr] }\end{array}$ & \multirow{3}{*}{$\begin{array}{c}\text { Window to Wall } \\
\text { Ratio } A: 75 \%- \\
100 \%\end{array}$} \\
\hline 16836 & \multirow{2}{*}{$31.20 \%$} & 17864 & \multirow{2}{*}{$35.48 \%$} & 17386 & \multirow{2}{*}{$31.91 \%$} & 15644 & \multirow{2}{*}{$21.88 \%$} & $\begin{array}{l}\text { Nat. gas } \\
{[\mathrm{kWh} / \mathrm{yr}]}\end{array}$ & \\
\hline 4736 & & 4411 & & 4303 & & 4394 & & $\begin{array}{l}\text { Electricity } \\
{[\mathrm{kWh} / \mathrm{yr}]}\end{array}$ & \\
\hline 4251 & $19.07 \%$ & 4212 & $17.98 \%$ & 3961 & $10.96 \%$ & 4072 & $14.06 \%$ & $\begin{array}{c}\text { Illuminance } \\
\text { [hrs/yr] }\end{array}$ & \multirow{3}{*}{$\begin{array}{l}\text { Window to Wall } \\
\text { Ratio B: } 55 \% \text { - } \\
65 \%\end{array}$} \\
\hline 16950 & \multirow{2}{*}{$30.34 \%$} & 16217 & \multirow{2}{*}{$25.24 \%$} & 15881 & \multirow{2}{*}{$22.15 \%$} & 15303 & \multirow{2}{*}{$19.07 \%$} & $\begin{array}{l}\text { Nat. gas } \\
\text { [kWh/yr] }\end{array}$ & \\
\hline 4481 & & 4375 & & 4203 & & 4275 & & $\begin{array}{l}\text { Electricity } \\
{[\mathrm{kWh} / \mathrm{yr}]}\end{array}$ & \\
\hline 4231 & $18.51 \%$ & 4193 & $17.44 \%$ & 3565 & $-0.14 \%$ & 3994 & $11.87 \%$ & Illuminance & \multirow{3}{*}{$\begin{array}{l}\text { Window to Wall } \\
\text { Ratio C: } 35 \%- \\
\quad 45 \%\end{array}$} \\
\hline 15581 & \multirow{2}{*}{$21.64 \%$} & 15553 & \multirow{2}{*}{$20.16 \%$} & 15139 & \multirow{2}{*}{$16.96 \%$} & 14831 & \multirow{2}{*}{$15.36 \%$} & Nat. gas & \\
\hline 4419 & & 4203 & & 4092 & & 4136 & & $\begin{array}{l}\text { Electricity } \\
{[\mathrm{kWh} / \mathrm{yr}]}\end{array}$ & \\
\hline 4227 & $18.41 \%$ & 4192 & $17.43 \%$ & 3565 & $-0.15 \%$ & 3993 & $11.86 \%$ & Illuminance & \multirow{4}{*}{$\begin{array}{l}\text { Window to Wall } \\
\text { Ratio D: } 20 \%- \\
35 \%\end{array}$} \\
\hline & \multirow{3}{*}{$17.64 \%$} & & \multirow{3}{*}{$18.04 \%$} & & \multirow{3}{*}{$15.70 \%$} & & \multirow{3}{*}{$13.30 \%$} & $\frac{[\mathrm{hrs} / \mathrm{yr}]}{\mathrm{Nat} \text { gas }}$ & \\
\hline 15219 & & 15308 & & 14933 & & 14533 & & {$[\mathrm{kWh} / \mathrm{yr}]$} & \\
\hline 4122 & & 4100 & & 4089 & & 4094 & & $\begin{array}{l}\text { Electricity } \\
{[\mathrm{kWh} / \mathrm{yr}]}\end{array}$ & \\
\hline
\end{tabular}

*Highlighted options correspond to the best performers in the priority scales

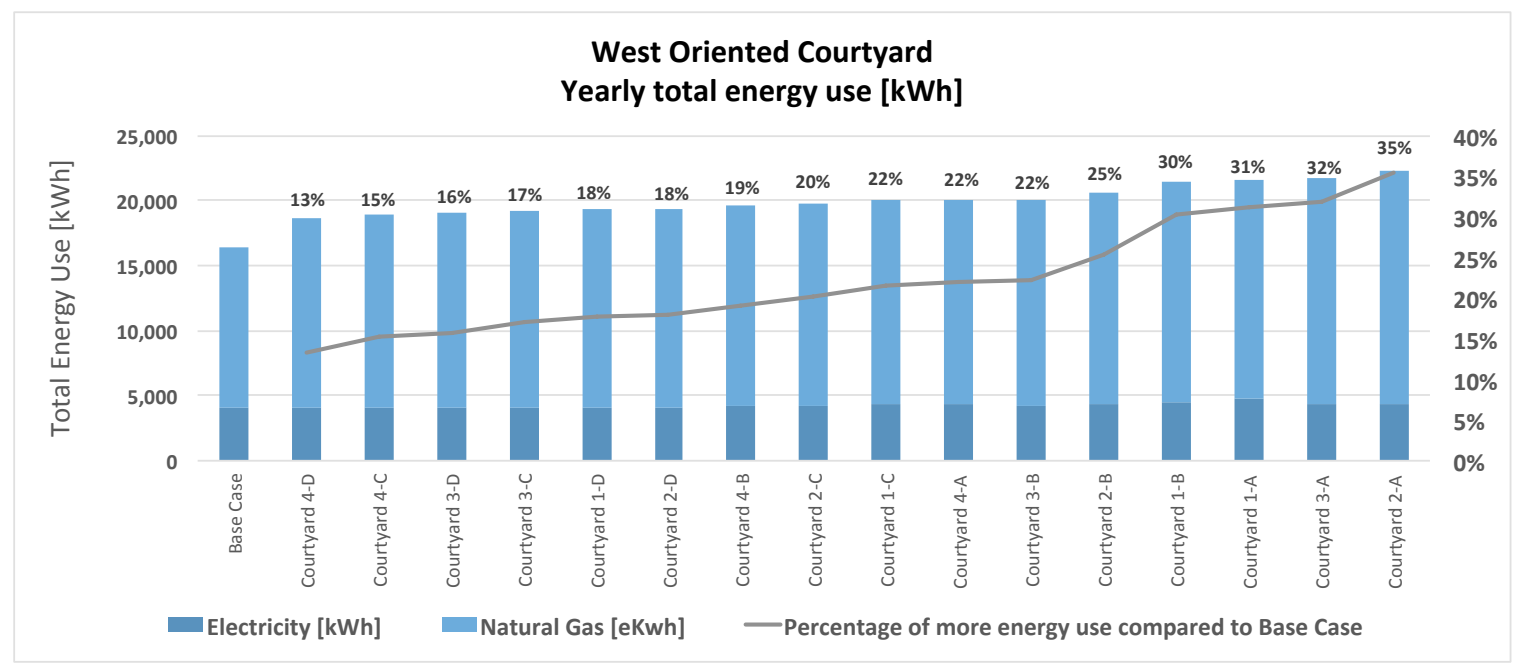



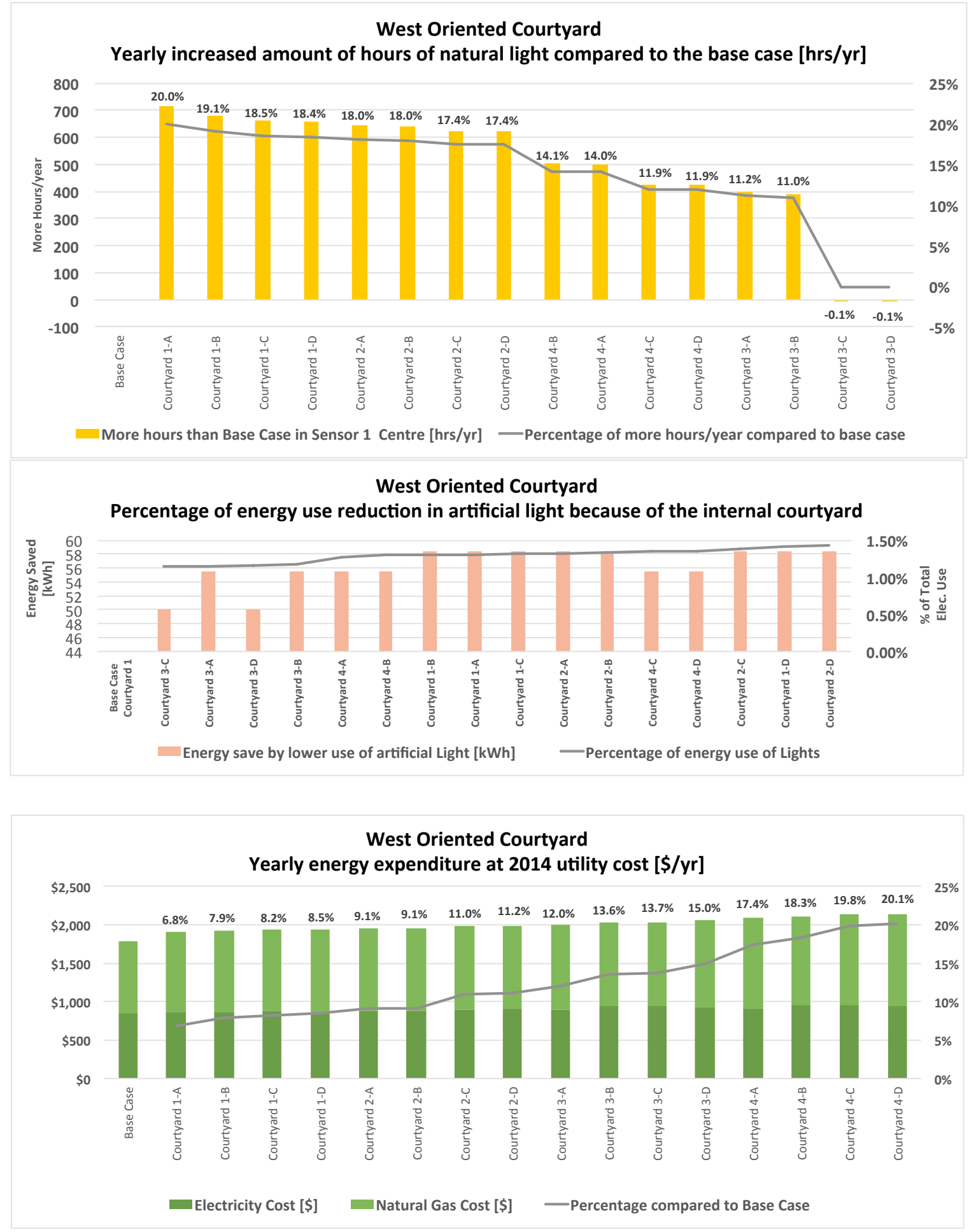
Appendix D - West Orientation Results
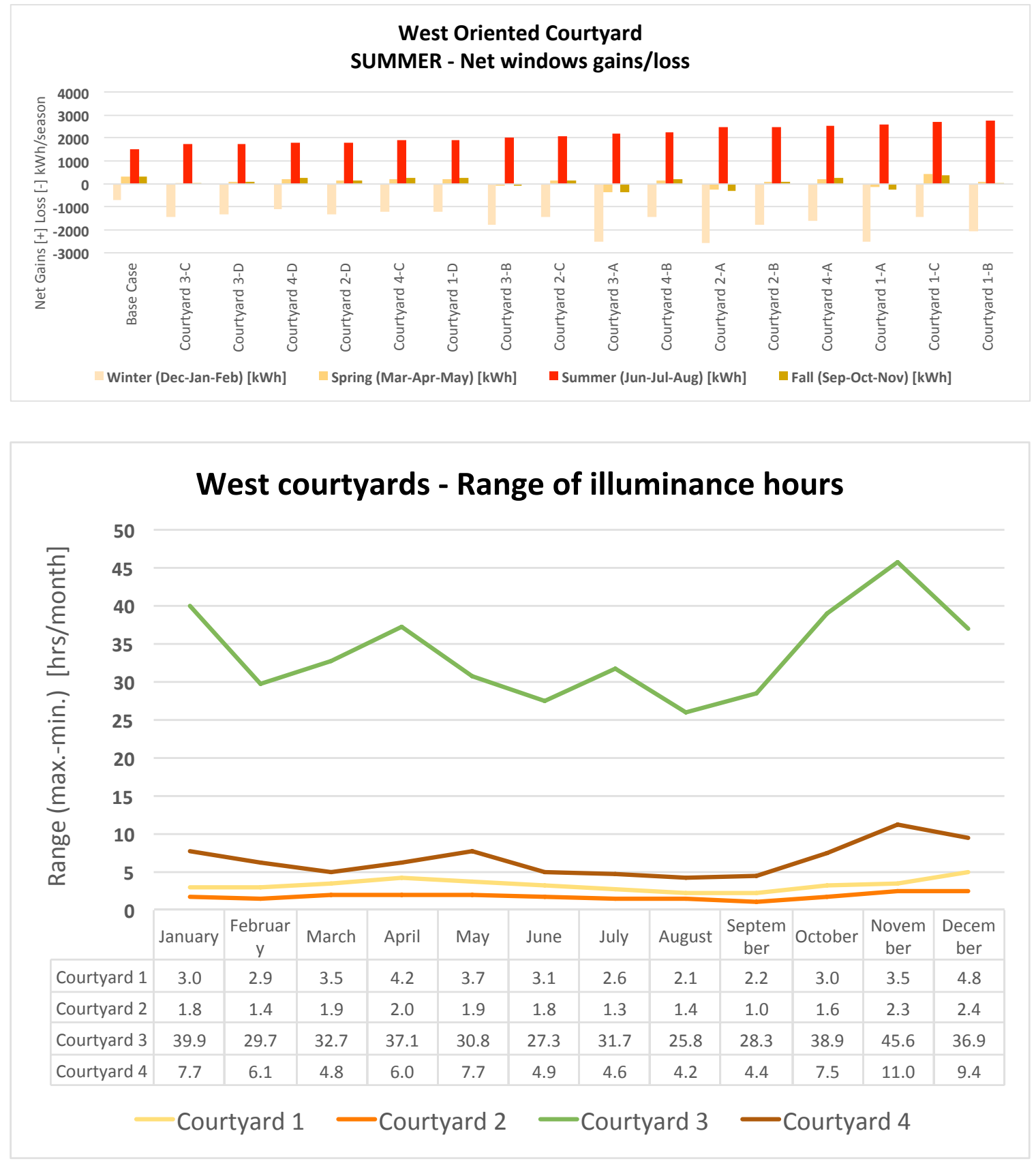


\section{Appendix D - West Orientation Results}

\begin{tabular}{|c|c|c|c|c|c|}
\hline & $\begin{array}{l}\text { Priority scale } \mathbf{1} \\
\text { Illuminance best } 8 \\
\text { 1st } \\
\text { Courtyard 2-D }\end{array}$ & $\begin{array}{l}\text { Natural gas best } 4 \\
\text { 2nd } \\
\text { Courtyard 1-D }\end{array}$ & $\begin{array}{l}\text { Electricity best } 2 \\
\text { 3rd } \\
\text { Courtyard 2-C }\end{array}$ & $\begin{array}{l}\text { 4th } \\
\text { Courtyard 1-C }\end{array}$ & \\
\hline Electricity $[k W h]$ & 4100 & 4122 & 4203 & & 4419 \\
\hline Natural Gas [eKwh] & 15308 & 15219 & 15553 & & 15581 \\
\hline Energy use increase compared to base case & $18.04 \%$ & $17.64 \%$ & $20.16 \%$ & & $21.64 \%$ \\
\hline Electricity Cost [\$] & $\$ 875$ & $\$ 880$ & $\$ 897$ & & $\$ 943$ \\
\hline Natural Gas Cost [\$] & $\$ 1,076$ & $\$ 1,071$ & $\$ 1,088$ & & $\$ 1,089$ \\
\hline Utility cost Increase compared to base case & $9.12 \%$ & $9.13 \%$ & $11.04 \%$ & & $13.70 \%$ \\
\hline Illuminance over 100lux [hrs/yr] & 4192 & 4227 & 4193 & & 4231 \\
\hline \multirow[t]{5}{*}{ More hours than base case $[\mathrm{hrs} / \mathrm{yr}]$} & 622 & 657 & 623 & & 661 \\
\hline & Priority scale 2 & & & & \\
\hline & Illuminance best 8 & Electricity best 4 & Natural gas Best 2 & & \\
\hline & & 2nd & 3 rd & 4th & \\
\hline & Courtyard 1-D & Courtyard 2-D & Courtyard 2-C & Courtyard 2-B & \\
\hline Electricity $[\mathrm{kWh}]$ & 4122 & 4100 & 4203 & & 4375 \\
\hline Natural Gas [eKwh] & 15219 & 15308 & 15553 & & 16217 \\
\hline Energy use increase compared to base case & $17.64 \%$ & $18.04 \%$ & $20.16 \%$ & & $25.24 \%$ \\
\hline Electricity Cost [\$] & $\$ 880$ & $\$ 875$ & $\$ 897$ & & $\$ 933$ \\
\hline Natural Gas Cost [\$] & $\$ 1,071$ & $\$ 1,076$ & $\$ 1,088$ & & $\$ 1,122$ \\
\hline Utility cost Increase compared to base case & $9.13 \%$ & $9.12 \%$ & $11.04 \%$ & & $14.98 \%$ \\
\hline Illuminance over 100lux [hrs/yr] & 4227 & 4192 & 4193 & & 4212 \\
\hline \multirow[t]{5}{*}{ More hours than base case [hrs/yr } & 657 & 622 & 623 & & 642 \\
\hline & Priority scale 3 & & & & \\
\hline & Natural gas best 8 & Electricity best 4 & Illuminance best 2 & & \\
\hline & & & 3rd & 4th & \\
\hline & Courtyard 2-D & Courtyard 4-D & Courtyard 3-C & Courtyard 3-D & \\
\hline Electricity [kWh] & 4100 & 4094 & 4092 & & 4089 \\
\hline Natural Gas [eKwh] & 15308 & 14533 & 15139 & & 14933 \\
\hline Energy use increase compared to base case & $18.04 \%$ & $13.30 \%$ & $16.96 \%$ & & $15.70 \%$ \\
\hline Electricity Cost [\$] & $\$ 875$ & $\$ 874$ & $\$ 873$ & & $\$ 872$ \\
\hline Natural Gas Cost [\$] & $\$ 1,076$ & $\$ 1,036$ & $\$ 1,067$ & & $\$ 1,057$ \\
\hline Utility cost Increase compared to base case & $9.12 \%$ & $6.85 \%$ & $8.54 \%$ & & $7.92 \%$ \\
\hline Illuminance over 100lux [hrs/yr] & 4192 & 3993 & 3565 & & 3565 \\
\hline \multirow[t]{5}{*}{ More hours than base case [hrs/yr } & 622 & 423 & -5 & & -5 \\
\hline & Priority scale 4 & & & & \\
\hline & Natural gas best 8 & Illuminance best 4 & Electricity best 2 & & \\
\hline & & & & 4th & \\
\hline & Courtyard 3-D & Courtyard 3-C & Courtyard 4-D & Courtyard 2-D & \\
\hline Electricity [kWh] & 4089 & 4092 & 4094 & & 4100 \\
\hline Natural Gas [eKwh] & 14933 & 15139 & 14533 & & 15308 \\
\hline Energy use increase compared to base case & $15.70 \%$ & $16.96 \%$ & $13.30 \%$ & & $18.04 \%$ \\
\hline Electricity Cost [\$] & $\$ 872$ & $\$ 873$ & $\$ 874$ & & $\$ 875$ \\
\hline Natural Gas Cost [\$] & $\$ 1,057$ & $\$ 1,067$ & $\$ 1,036$ & & $\$ 1,076$ \\
\hline Utility Cost Increase compared to base case & $7.92 \%$ & $8.54 \%$ & $6.85 \%$ & & $9.12 \%$ \\
\hline Illuminance over 100lux [hrs/yr] & 3565 & 3565 & 3993 & & 4192 \\
\hline \multirow[t]{5}{*}{ More hours than base case $[\mathrm{hrs} / \mathrm{yr}]$} & -5 & -5 & 423 & & 622 \\
\hline & Priority scale 5 & & & & \\
\hline & Electricity best 8 & Natural gas best 4 & Illuminance best 2 & & \\
\hline & 1st & 2nd & 3rd & 4th & \\
\hline & Courtyard 4-C & Courtyard 4-D & Courtyard 3-C & Courtyard 3-D & \\
\hline Electricity [kWh] & 4136 & 4094 & 4092 & & \\
\hline Natural Gas [eKwh] & 14831 & 14533 & 15139 & & 14933 \\
\hline Energy use increase compared to base case & $15.36 \%$ & $13.30 \%$ & $16.96 \%$ & & $15.70 \%$ \\
\hline Electricity Cost [\$\$] & $\$ 882$ & $\$ 874$ & $\$ 873$ & & $\$ 872$ \\
\hline Natural Gas Cost [\$] & $\$ 1,051$ & $\$ 1,036$ & $\$ 1,067$ & & $\$ 1,057$ \\
\hline Utility Cost Increase compared to base case & $8.19 \%$ & $6.85 \%$ & $8.54 \%$ & & $7.92 \%$ \\
\hline Illuminance over 100lux [hrs/yr] & 3994 & 3993 & 3565 & & 3565 \\
\hline \multirow[t]{5}{*}{ More hours than base case [hrs/yr] } & 424 & 423 & -5 & & -5 \\
\hline & Priority scale 6 & & & & \\
\hline & Electricity best 8 & Illuminance best 4 & Natural gas best 2 & & \\
\hline & & 2nd & 3 rd & 4th & \\
\hline & Courtyard 4-C & Courtyard 1-D & Courtyard 2-D & Courtyard 2-C & \\
\hline Electricity [kWh] & 4136 & 4122 & 4100 & & 4203 \\
\hline Natural Gas [eKwh] & 14831 & 15219 & 15308 & & \\
\hline Energy use increase compared to base case & $15.36 \%$ & $17.64 \%$ & $18.04 \%$ & & $20.16 \%$ \\
\hline Electricity Cost [\$] & $\$ 882$ & $\$ 880$ & $\$ 875$ & & $\$ 897$ \\
\hline Natural Gas Cost [\$] & $\$ 1,051$ & $\$ 1,071$ & $\$ 1,076$ & & $\$ 1,088$ \\
\hline Utility Cost Increase compared to base case & $8.19 \%$ & $9.13 \%$ & $9.12 \%$ & & $11.04 \%$ \\
\hline Illuminance over 100lux [hrs/yr] & 3994 & 4227 & 4192 & & 4193 \\
\hline More hours than base case [hrs/yr] & 424 & 657 & 622 & & \\
\hline
\end{tabular}




\section{Appendix D - West Orientation Results - Courtyard 1 WEST}
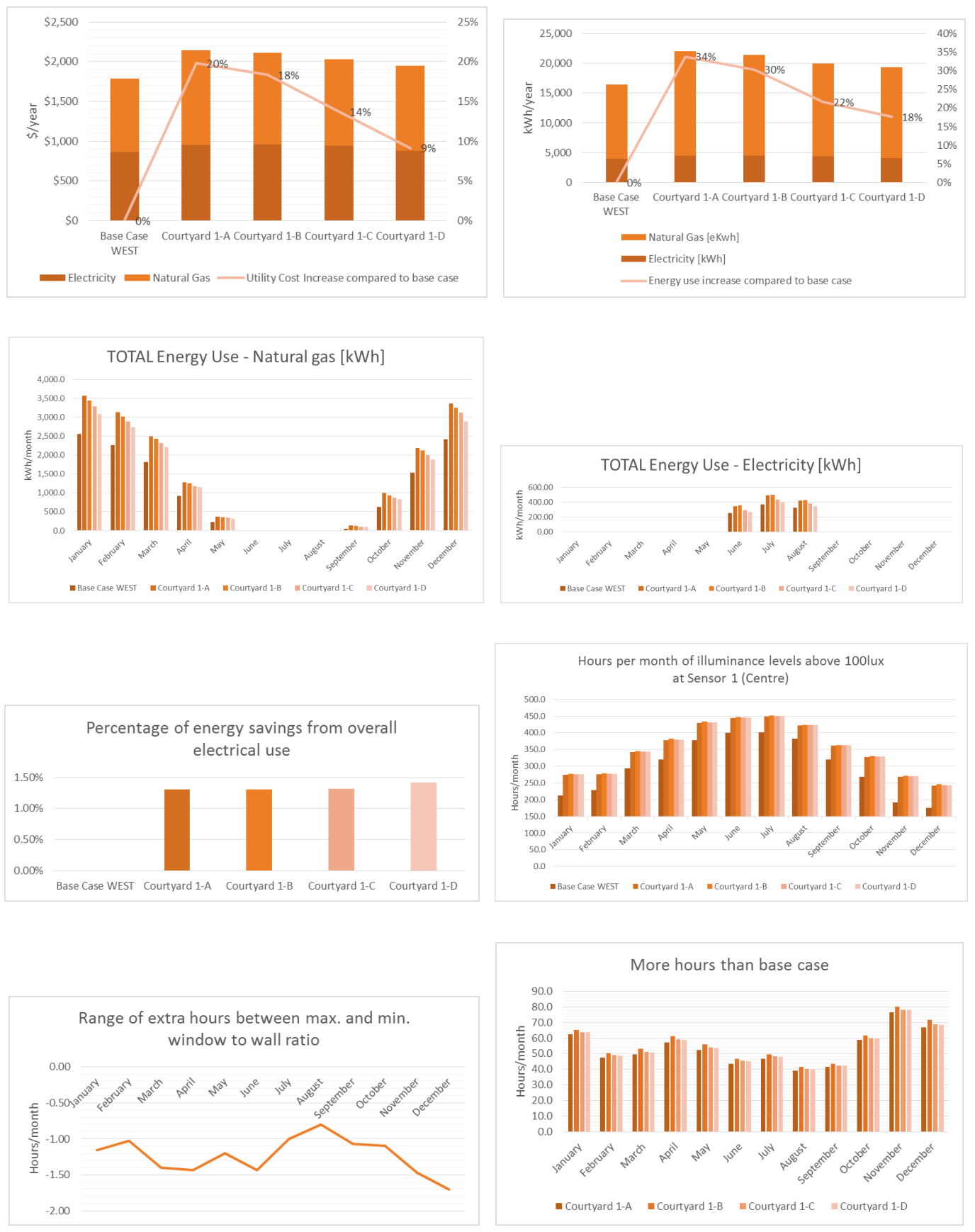


\section{Appendix D - West Orientation Results - Courtyard 2 WEST}
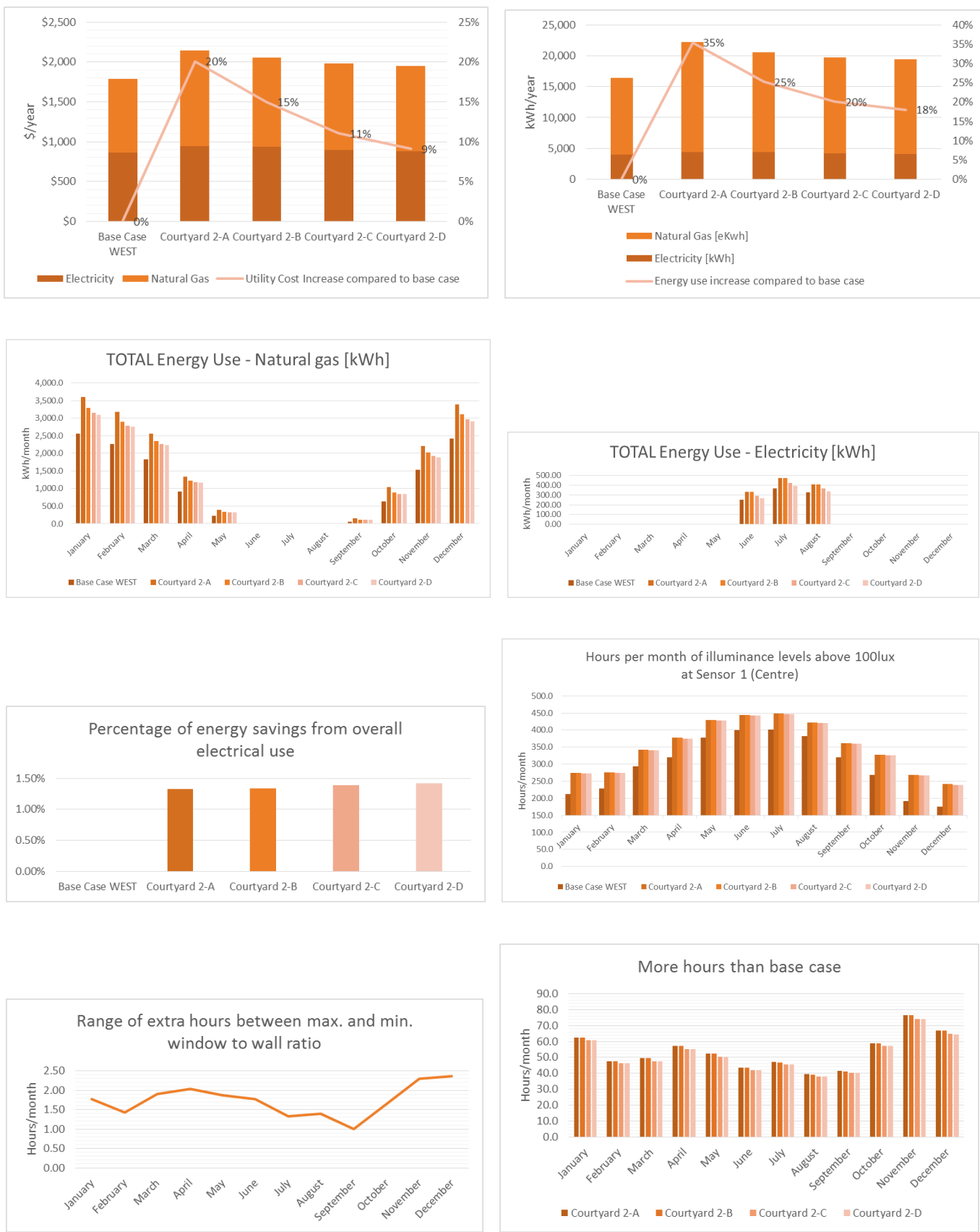


\section{Appendix D - West Orientation Results - Courtyard 3 WEST}
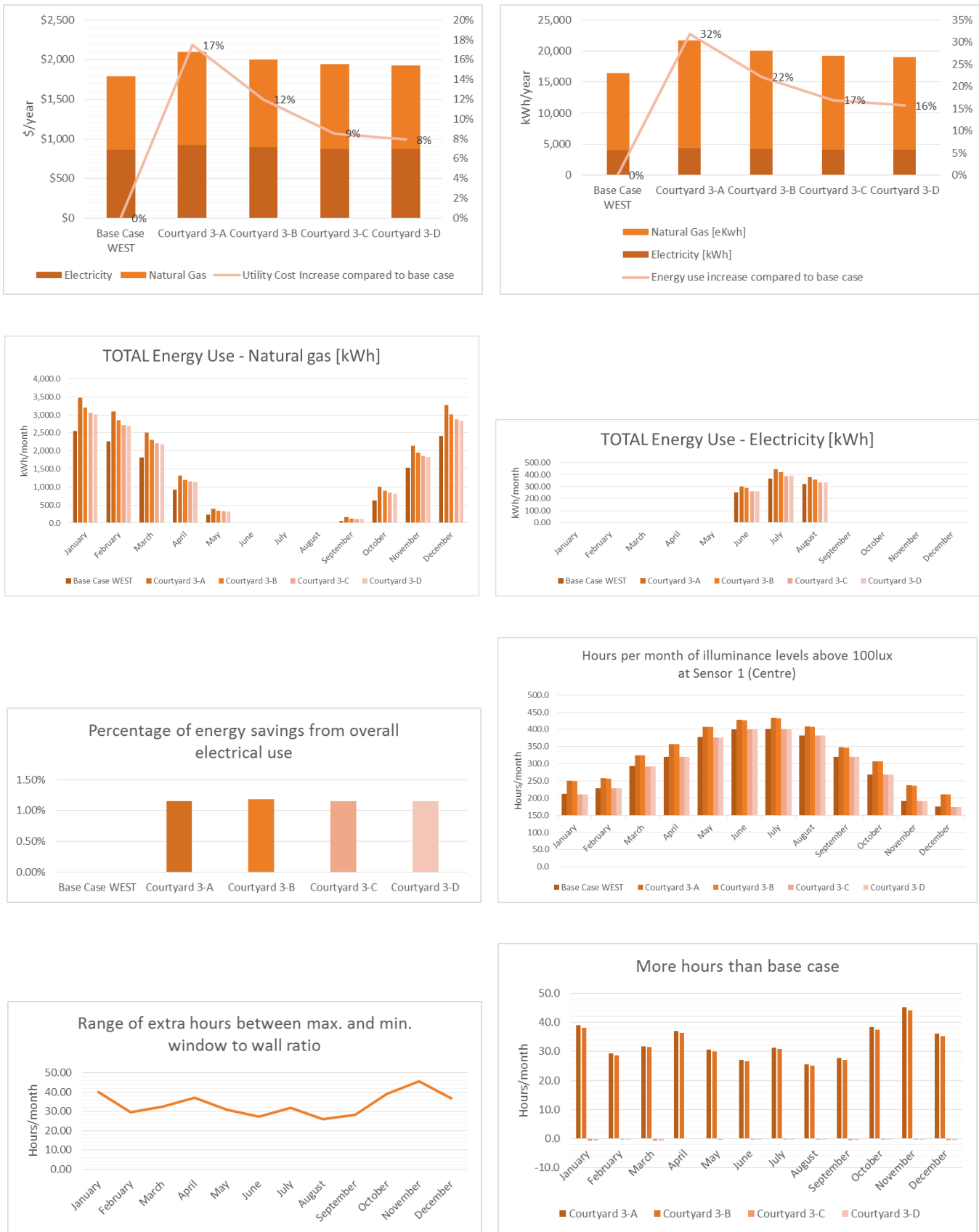


\section{Appendix D - West Orientation Results - Courtyard 4 WEST}
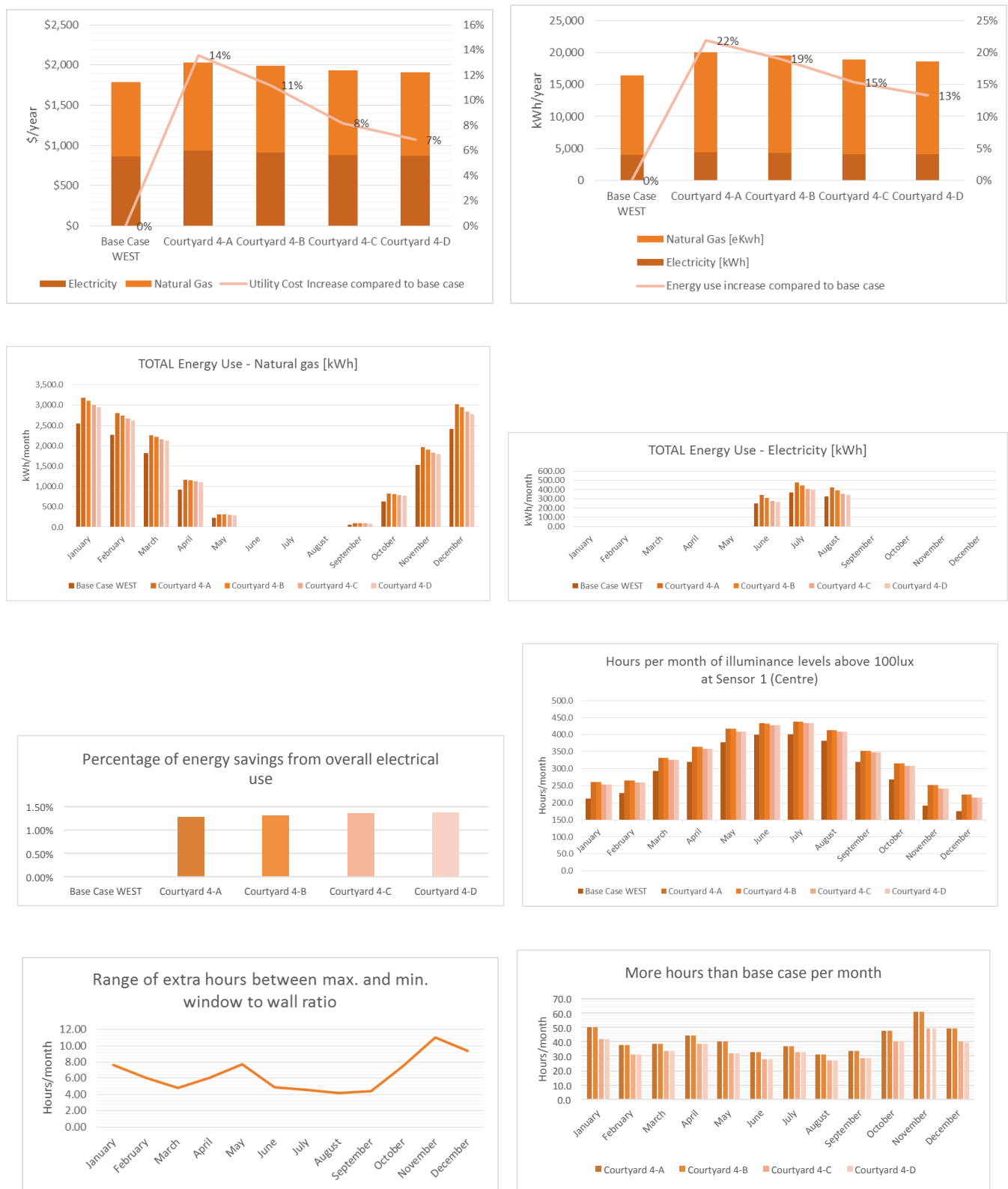


\section{Appendix E - Energy bills calibration}

\begin{tabular}{|c|c|c|c|c|c|c|c|c|c|c|c|c|c|}
\hline & May & Apr & Mar & Feb & Jan & Dec & Nov & Oct & Sep & Aug & Jul & Jun & Annual Total \\
\hline Electricity consumption (kWh) & 468.1 & 388.6 & 369.0 & 421.8 & 501.3 & 517.6 & 510.9 & 363.8 & 287.1 & 265.4 & 250.5 & 105.6 & 4449.7 \\
\hline Electricity charges & $\$ 81.3$ & $\$ 67.5$ & $\$ 67.8$ & $\$ 73.3$ & $\$ 85.6$ & $\$ 88.2$ & $\$ 87.0$ & $\$ 63.2$ & $\$ 49.9$ & $\$ 46.1$ & $\$ 43.5$ & $\$ 18.4$ & $\$ 771.8$ \\
\hline HST & $\$ 10.6$ & $\$ 8.8$ & $\$ 8.8$ & $\$ 9.5$ & $\$ 11.1$ & $\$ 11.5$ & $\$ 11.3$ & $\$ 8.2$ & $\$ 6.5$ & $\$ 6.0$ & $\$ 5.7$ & $\$ 2.4$ & $\$ 100.3$ \\
\hline Ontario clean energy & $\$ 8.1$ & $\$ 6.8$ & $\$ 6.8$ & $\$ 7.3$ & $\$ 8.6$ & $\$ 8.8$ & $\$ 8.7$ & $\$ 6.3$ & $\$ 5.0$ & $\$ 4.6$ & $\$ 4.4$ & $\$ 1.8$ & $\$ 77.2$ \\
\hline Monthly total & $\$ 100.1$ & $\$ 83.1$ & $\$ 83.4$ & $\$ 90.1$ & $\$ 105.2$ & $\$ 108.5$ & $\$ 107.0$ & $\$ 77.8$ & $\$ 61.4$ & $\$ 56.7$ & $\$ 53.5$ & $\$ 22.6$ & $\$ 949.4$ \\
\hline Gas consumption (m3) & 144 & 257 & 113 & 891 & 519 & 550 & 143 & 213 & 21 & 97 & 112 & 102 & 3162.0 \\
\hline ekWh & 1497.6 & 2672.8 & 1175.2 & 9266.4 & 5397.6 & 5720 & 1487.2 & 2215.2 & 218.4 & 1008.8 & 1164.8 & 1060.8 & $32,884.8$ \\
\hline Customer charge & $\$ 20.0$ & $\$ 20.0$ & $\$ 20.0$ & $\$ 20.0$ & $\$ 20.0$ & $\$ 20.0$ & $\$ 20.0$ & $\$ 20.0$ & $\$ 20.0$ & $\$ 20.0$ & $\$ 20.0$ & $\$ 20.0$ & $\$ 240.0$ \\
\hline \begin{tabular}{|l} 
Delivery \\
\end{tabular} & $\$ 11.3$ & $\$ 19.6$ & $\$ 8.9$ & $\$ 64.9$ & $\$ 38.0$ & $\$ 39.9$ & $\$ 11.0$ & $\$ 16.0$ & $\$ 1.7$ & $\$ 7.6$ & $\$ 8.8$ & $\$ 8.0$ & $\$ 235.6$ \\
\hline Cost adjustment & $\$ 5.8$ & $\$ 7.8$ & $\$ 0.3$ & $\$ 2.0$ & $\$ 1.1$ & $\$ 1.1$ & $\$ 0.3$ & $\$ 0.4$ & $\$ 0.0$ & $\$ 0.1$ & $\$ 0.2$ & $\$ 0.1$ & $\$ 19.0$ \\
\hline Admin Fee & $\$ 0.4$ & $\$ 0.4$ & $\$ 0.4$ & $\$ 0.4$ & $\$ 0.4$ & $\$ 0.4$ & $\$ 0.4$ & $\$ 0.4$ & $\$ 0.4$ & $\$ 0.4$ & $\$ 0.2$ & $\$ 0.2$ & 4.4 \\
\hline Transportation to Enbridge & $\$ 6.9$ & $\$ 12.3$ & $\$ 5.4$ & $\$ 51.5$ & $\$ 44.1$ & $\$ 46.8$ & $\$ 12.2$ & $\$ 18.1$ & $\$ 1.8$ & $\$ 8.2$ & $\$ 9.5$ & $\$ 8.7$ & $\$ 225.4$ \\
\hline Gas supply charge & $\$ 30.2$ & $\$ 53.9$ & $\$ 23.7$ & $\$ 208.1$ & $\$ 155.2$ & $\$ 164.5$ & $\$ 42.8$ & $\$ 63.7$ & $\$ 6.3$ & $\$ 29.0$ & $\$ 33.5$ & $\$ 30.5$ & $\$ 841.4$ \\
\hline HST & $\$ 9.7$ & $\$ 14.8$ & $\$ 7.6$ & $\$ 45.1$ & $\$ 33.7$ & $\$ 35.4$ & $\$ 11.3$ & $\$ 15.4$ & $\$ 3.9$ & $\$ 8.5$ & $\$ 9.4$ & $\$ 8.8$ & $\$ 203.6$ \\
\hline Monthly Total & $\$ 84.3$ & $\$ 128.7$ & $\$ 66.3$ & $\$ 392.0$ & $\$ 292.5$ & $\$ 307.9$ & $\$ 97.8$ & $\$ 134.1$ & $\$ 34.2$ & $\$ 73.7$ & $\$ 81.6$ & $\$ 76.2$ & $\$ 1,769.3$ \\
\hline
\end{tabular}




\section{Appendix F - Utility cost - 2014 base}
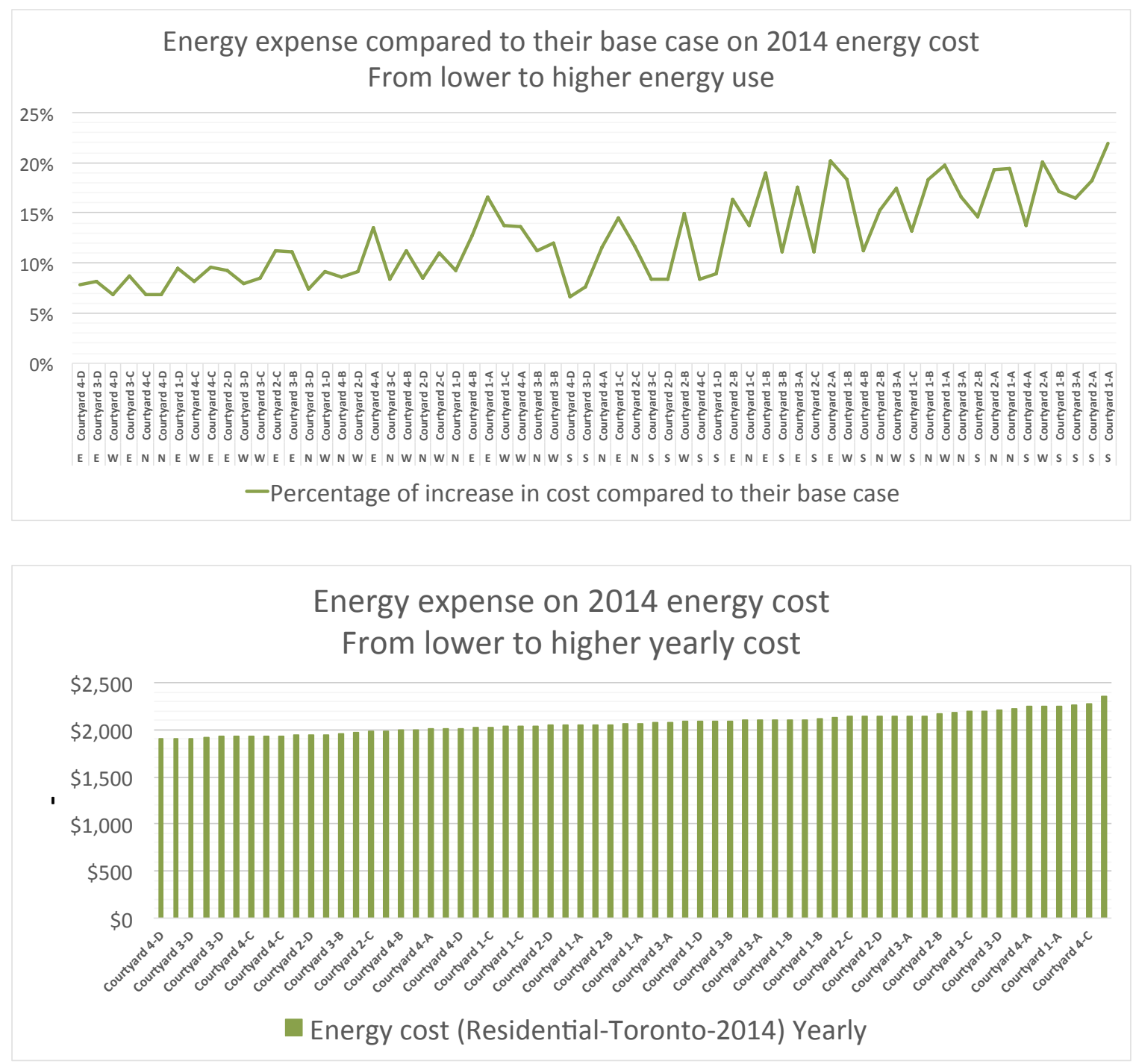

Annual utility cost based on 2014 utility bills for residential customers in the city of Toronto 


\title{
Appendix G - Building code and zoning
}

\author{
Table 2.1.2. A
}

ZONE 1 - Compliance Packages for Space Heating Equipment with AFUE $\geq 90 \%$ Forming Part of Sentence 2.1.1.2.(1)

\begin{tabular}{|c|c|c|c|c|c|c|c|c|c|c|c|c|c|}
\hline \multirow{2}{*}{ Component } & \multicolumn{13}{|c|}{ Compliance Package } \\
\hline & $A$ & $B$ & $\mathrm{C}$ & $\mathrm{D}$ & $E$ & $\mathrm{~F}$ & $G$ & $\mathrm{H}$ & 1 & $\mathrm{~J}$ & $\kappa^{(3)}$ & $L^{(4)}$ & $M^{(5)}$ \\
\hline $\begin{array}{l}\text { Ceing with Attic Space } \\
\text { Mrimum RSI (R)-Value }\end{array}$ & $\begin{array}{l}8.81 \\
(\mathrm{R} 50)\end{array}$ & $\begin{array}{l}8.81 \\
(R 50)\end{array}$ & $\begin{array}{l}8.81 \\
\text { (R50) }\end{array}$ & $\begin{array}{c}8.81 \\
\text { (R50) }\end{array}$ & $\begin{array}{l}8.81 \\
(R 50)\end{array}$ & $\begin{array}{l}8.81 \\
\text { (R50) }\end{array}$ & $\begin{array}{l}8.81 \\
\text { (R50) }\end{array}$ & $\begin{array}{l}8.81 \\
\text { (R50) }\end{array}$ & $\begin{array}{l}8.81 \\
\text { (R50) }\end{array}$ & $\begin{array}{l}8.81 \\
\text { (R50) }\end{array}$ & $\begin{array}{l}8.81 \\
\text { (R50) }\end{array}$ & $\begin{array}{l}8.81 \\
\text { (R50) }\end{array}$ & $\begin{array}{l}8.81 \\
\text { (R50) }\end{array}$ \\
\hline $\begin{array}{l}\text { Ceilng Without Attic Space } \\
\text { Minimum RSI (R)-Value }\end{array}$ & $\begin{array}{c}5.46 \\
(\mathrm{R} 31)\end{array}$ & $\begin{array}{l}5.46 \\
\text { (R31) }\end{array}$ & $\begin{aligned} 5.46 \\
(\mathrm{R} 31)\end{aligned}$ & $\begin{array}{c}5.46 \\
(\mathrm{R} 31)\end{array}$ & $\begin{array}{l}5.46 \\
(\mathrm{R} 31)\end{array}$ & $\begin{array}{r}5.46 \\
\text { (R31) }\end{array}$ & $\begin{aligned} 5.46 \\
(\mathrm{R} 31)\end{aligned}$ & $\begin{array}{c}5.46 \\
(\mathrm{R} 31)\end{array}$ & $\begin{array}{r}5.46 \\
(\mathrm{R} 31)\end{array}$ & $\begin{array}{r}5.46 \\
(\mathrm{R} 31)\end{array}$ & $\begin{array}{r}5.46 \\
(\text { (R31) }\end{array}$ & $\begin{array}{l}5.46 \\
(\mathrm{R} 31)\end{array}$ & $\begin{array}{l}5.46 \\
\text { (R31) }\end{array}$ \\
\hline $\begin{array}{l}\text { Exposed Floor } \\
\text { Mnimum RSI (R)-Value }{ }^{(1)}\end{array}$ & $\begin{array}{c}5.46 \\
\text { (R31) }\end{array}$ & $\begin{array}{l}5.46 \\
\text { (R31) }\end{array}$ & $\begin{array}{l}5.46 \\
\text { (R31) }\end{array}$ & $\begin{array}{c}5.46 \\
\text { (R31) }\end{array}$ & $\begin{array}{l}5.46 \\
\text { (R31) }\end{array}$ & $\begin{array}{l}5.46 \\
\text { (R31) }\end{array}$ & $\begin{array}{l}5.46 \\
\text { (R31) }\end{array}$ & $\begin{array}{l}5.46 \\
\text { (R31) }\end{array}$ & $\begin{array}{l}5.46 \\
\text { (R31) }\end{array}$ & $\begin{array}{l}5.46 \\
\text { (R31) }\end{array}$ & $\begin{array}{l}5.46 \\
\text { (R31) }\end{array}$ & $\begin{array}{l}5.46 \\
\text { (R31) }\end{array}$ & $\begin{array}{l}5.46 \\
\text { (R31) }\end{array}$ \\
\hline $\begin{array}{l}\text { Walls Above Grade } \\
\text { Mnimum RSI (R)-Value }\end{array}$ & $\begin{array}{l}4.23 \\
(\mathrm{R} 24)\end{array}$ & $\begin{array}{l}4.75 \\
\text { (R27) }\end{array}$ & $\begin{array}{r}4.75 \\
(\text { (R227) }\end{array}$ & $\begin{array}{r}4.23 \\
\text { (R24) }\end{array}$ & $\begin{array}{l}423 \\
(\mathrm{R} 24)\end{array}$ & $\begin{array}{r}4.23 \\
(\mathrm{R} 24)\end{array}$ & $\begin{array}{r}4.23 \\
(\mathrm{R} 224)\end{array}$ & $\begin{array}{r}4.23 \\
(\mathrm{R} 24)\end{array}$ & $\begin{array}{l}3.87 \\
\text { (R22) }\end{array}$ & $\begin{aligned} & 3.87 \\
&(\mathrm{R} 22)\end{aligned}$ & $\begin{aligned} 3.87 \\
(\mathrm{R} 22)\end{aligned}$ & $\begin{array}{l}4.23 \\
(\mathrm{R} 24)\end{array}$ & $\begin{aligned} 4.23 \\
(\mathrm{R} 24)\end{aligned}$ \\
\hline $\begin{array}{l}\text { Basement Walls } \\
\text { Mnimum RSI (R)-Value }{ }^{(1)}\end{array}$ & $\begin{array}{c}3.52 \\
\text { (R20) }\end{array}$ & $\begin{array}{l}3.52 \\
\text { (R20) }\end{array}$ & $\begin{array}{l}3.52 \\
\text { (R20) }\end{array}$ & $\begin{array}{c}3.52 \\
\text { (R20) }\end{array}$ & $\begin{array}{c}3.52 \\
\text { (R20) }\end{array}$ & $\begin{array}{c}2.11 \\
\text { (R12) }\end{array}$ & $\begin{array}{l}2.11 \\
\text { (R12) }\end{array}$ & $\begin{array}{c}2.11 \\
\text { (R12) }\end{array}$ & $\begin{array}{r}3.52 \\
\text { (R20) }\end{array}$ & $\begin{array}{c}2.11 \\
\text { (R12) }\end{array}$ & $\begin{array}{l}3.87 \\
\text { (R22) }\end{array}$ & $\begin{array}{c}3.87 \\
\text { (R22) }\end{array}$ & $\begin{array}{c}3.52 \\
\text { (R20) }\end{array}$ \\
\hline $\begin{array}{l}\text { Below Grade Slab } \\
\text { Entre surface > } 600 \mathrm{~mm} \\
\text { below grade } \\
\text { Mnimum RSI (R)-Value }{ }^{(1)}\end{array}$ & $\begin{array}{l}0.88 \\
\text { (R5) }\end{array}$ & - & - & - & - & - & - & - & - & - & - & - & - \\
\hline $\begin{array}{l}\text { Edge of Below Grade Slab } \\
\leq 600 \mathrm{~mm} \text { Below Grade } \\
\text { Mrimum RSI (R)-Value }\end{array}$ & $\begin{array}{c}1.76 \\
(\mathrm{R} 10)\end{array}$ & $\begin{array}{c}1.76 \\
\text { (R10) }\end{array}$ & $\begin{array}{l}1.76 \\
\text { (R10) }\end{array}$ & $\begin{array}{l}1.76 \\
\text { (R10) }\end{array}$ & $\begin{array}{r}1.76 \\
\text { (R10) }\end{array}$ & $\begin{array}{l}1.76 \\
\text { (R10) }\end{array}$ & $\begin{array}{l}1.76 \\
\text { (R10) }\end{array}$ & $\begin{array}{l}1.76 \\
\text { (R10) }\end{array}$ & $\begin{array}{l}1.76 \\
\text { (R10) }\end{array}$ & $\begin{array}{l}1.76 \\
\text { (R10) }\end{array}$ & $\begin{array}{l}1.76 \\
\text { (R10) }\end{array}$ & $\begin{array}{l}1.76 \\
(\mathrm{R} 10)\end{array}$ & $\begin{array}{l}1.76 \\
\text { (R10) }\end{array}$ \\
\hline $\begin{array}{l}\text { Heated Slab or } \\
\text { Slab } \leq 600 \mathrm{~mm} \text { below grade } \\
\text { Mnimum RSI (R)-Value }\end{array}$ & $\begin{array}{l}1.76 \\
(\mathrm{R} 10)\end{array}$ & $\begin{array}{c}1.76 \\
\text { (R10) }\end{array}$ & $\begin{array}{l}1.76 \\
\text { (R10) }\end{array}$ & $\begin{array}{r}1.76 \\
\text { (R10) }\end{array}$ & $\begin{array}{r}1.76 \\
\text { (R10) }\end{array}$ & $\begin{array}{r}1.76 \\
\text { (R10) }\end{array}$ & $\begin{array}{c}1.76 \\
\text { (R10) }\end{array}$ & $\begin{array}{c}1.76 \\
\text { (R10) }\end{array}$ & $\begin{array}{l}1.76 \\
\text { (R10) }\end{array}$ & $\begin{array}{r}1.76 \\
\text { (R10) }\end{array}$ & $\begin{array}{l}1.76 \\
\text { (R10) }\end{array}$ & $\begin{array}{l}1.76 \\
(\mathrm{R} 10)\end{array}$ & $\begin{array}{r}1.76 \\
\text { (R10) }\end{array}$ \\
\hline $\begin{array}{l}\text { Windows and Sliding Glass } \\
\text { Doors } \\
\text { Maximum U-Value }\end{array}$ & 1.6 & 1.6 & 1.8 & 1.8 & 1.8 & 1.8 & 1.8 & 2 & 1.8 & 1.8 & 1.8 & 1.8 & 1.8 \\
\hline $\begin{array}{l}\text { Skylights } \\
\text { Maximum U-Value }^{(2)}\end{array}$ & 2.8 & 2.8 & 2.8 & 2.8 & 2.8 & 2.8 & 2.8 & 2.8 & 2.8 & 2.8 & 2.8 & 2.8 & 2.8 \\
\hline $\begin{array}{l}\text { Space Heating Equipment } \\
\text { Mnimum AFUE }\end{array}$ & $90 \%$ & $90 \%$ & $94 \%$ & $94 \%$ & $90 \%$ & $94 \%$ & $92 \%$ & $94 \%$ & $92 \%$ & $94 \%$ & $90 \%$ & $94 \%$ & $90 \% \%^{187}$ \\
\hline $\begin{array}{l}\text { HRV } \\
\text { Mnimum Efficiency }\end{array}$ & - & - & - & - & $55 \%$ & $60 \%$ & $60 \%$ & $70 \%$ & $55 \%$ & $60 \%$ & - & - & - \\
\hline $\begin{array}{l}\text { Domestic Hot Water Heater } \\
\text { Mnimum EF }\end{array}$ & 0.57 & 0.57 & 0.62 & 0.67 & 0.57 & 0.57 & 0.62 & 0.67 & 0.62 & 0.67 & 0.57 & 0.57 & $0.80^{(8)}$ \\
\hline Column 1 & $\overline{2}$ & 3 & 4 & 5 & 6 & 7 & 8 & 9 & 10 & 11 & 12 & 13 & 14 \\
\hline
\end{tabular}

Notes to Table 2.1.1.2.A:

(1) The values listed are minimum RSI-Values for the thermal insulation component only. RSI-Values expressed in ( $\left.\mathrm{m}^{2} \cdot \mathrm{K}\right) \mathrm{W}$.

(2) U-Value is the overall coefficient of heat transfer expressed in $\mathrm{W} /\left(\mathrm{m}^{2}-\mathrm{K}\right)$.

(3) Compliance package K applies only to a buiding with both ICF basement walls and ICF above grade walls. Altematively, any other compliance package is permitted to be used for a bunding with both ICF basement walls and ICF above grade walls. The thermal insulation value of an ICF wall is the sum of the insulation value on both sides of the walls.

(4) Compliance package L applies only to a buiding with ICF basement walls. Alternatively, any other compliance package except compliance package K, is permitted to be used for a buiding with ICF basement walls. The thermal insulation value of an ICF wall is the sum of the insulation value on both sides of the walls.

(5) Applies to a building with combined space heating and domestic hot water heating system.

(6) Except as required in Subsection 9.32.3. of Division B in the Buiding Code, an HRV is only required as a part of the compliance package where a minimum efficiency level is specifed.

(7) The minimum efficiency of an HRV shall be based on a test temperature of $0^{\circ} \mathrm{C}$. In addition, where an $\mathrm{HRV}$ is installed to meet the requirements of Subsection 9.32.3. of Division B in the Bunding Code, the energy efficiency of the HRV shall also meet the minimum efficiency requirements of Sentence 9.32.3.11.(2).

(8) Combined space heating and domestic hot water heating equipment shall have minimum energy efficiency ratings specified or shall be of the condensing type.

SB-12 Page 10 


\section{Toronto Zoning Bylaw 438-86 - Zoning Information}

This information sheet lists the general requirements for each residential zone and is for convenience purposes only. For complete information, refer to Former City of Toronto Zoning By-law 483-386 as amended.

\section{Permitted Use(s)}

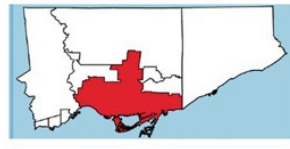

\begin{tabular}{l|c|c|c|c|c|c|c|c|c}
\multirow{2}{*}{ Type of Building } & \multicolumn{8}{|c}{ Zone } \\
\cline { 2 - 9 } & R1 & R1S & R2 & R3 & R4 & R4A & CR & MCR \\
\hline Row house & - & - & Yes & Yes & Yes & Yes & Yes & Yes \\
\hline Rowplex & - & - & - & Yes & Yes & Yes & Yes & Yes \\
\hline
\end{tabular}

\section{Requirements}

\begin{tabular}{|c|c|c|c|c|c|c|c|c|}
\hline $\begin{array}{l}\text { Duplex, Triplex, } \\
\text { Row House, } \\
\text { Rowplex }\end{array}$ & $\begin{array}{l}R \\
1\end{array}$ & R1S & R2 & R3 & R4 & R4A & CR & MCR \\
\hline $\begin{array}{l}\text { Max. Gross Floor } \\
\text { Area (Residential) }\end{array}$ & \multicolumn{6}{|c|}{$\begin{array}{l}0.35 \text { to } 2.5 \text { times lot area is the permitted density in } \\
\text { Residential Districts. The permitted density is indicated by } \\
\text { the number following the ' } Z \text { ' symbol. }\end{array}$} & \multicolumn{2}{|c|}{$\begin{array}{l}\text { See 'T', 'C' and } \\
\text { 'R' symbol for } \\
\text { permitted } \\
\text { density. }\end{array}$} \\
\hline $\begin{array}{l}\text { Front Yard } \\
\text { Setback }\end{array}$ & \multicolumn{6}{|c|}{$\begin{array}{l}\text { Avg. of front yard setbacks of two adjacent neighbours } \\
\text { (less than or equal to } 6.0 \mathrm{~m} \text { ) }\end{array}$} & $0.0 \mathrm{~m}$ & $0.0 \mathrm{~m}$ \\
\hline Side Setback & - & $3.0 \mathrm{~m}$ & & & & & & \\
\hline $\begin{array}{l}\text { where the side } \\
\text { wall has no doors } \\
\text { or windows }\end{array}$ & - & N/A & $0.45 \mathrm{~m}$ & $0.45 \mathrm{~m}$ & $0.45 \mathrm{~m}$ & $0.45 \mathrm{~m}$ & $0.0 \mathrm{~m}$ & $0.0 \mathrm{~m}$ \\
\hline $\begin{array}{l}\text { where the side } \\
\text { wall has doors or } \\
\text { windows }\end{array}$ & - & N/A & $1.2 \mathrm{~m}$ & $1.2 \mathrm{~m}$ & $1.2 \mathrm{~m}$ & $1.2 \mathrm{~m}$ & \multicolumn{2}{|c|}{$\begin{array}{l}\text { See Ont. Building } \\
\text { Code }\end{array}$} \\
\hline Rear Setback & - & $7.5 \mathrm{~m}$ & $7.5 \mathrm{~m}$ & $7.5 \mathrm{~m}$ & $7.5 \mathrm{~m}$ & $7.5 \mathrm{~m}$ & $0.0 \mathrm{~m}$ & $0.0 \mathrm{~m}$ \\
\hline Max. Depth & - & $14 \mathrm{~m}$ & $14 \mathrm{~m}$ & $14 \mathrm{~m}$ & $14 \mathrm{~m}$ & $14 \mathrm{~m}$ & N/A & $\mathrm{N} / \mathrm{A}$ \\
\hline Min. Landscaping & - & \multicolumn{5}{|c|}{$\begin{array}{c}\text { Density zone } 0.35 \text { to } 1.5: 30 \% \text {. Density zone } 2.0 \text { or } \\
\qquad 2.5: 35 \%\end{array}$} & N/A & N/A \\
\hline Min. Parking & - & \multicolumn{7}{|c|}{$\begin{array}{l}1.0 \text { parking space per dwelling unit - For Parking Space Sizes, refer to By- } \\
\qquad \text { law \# 494-2007 }\end{array}$} \\
\hline \multicolumn{9}{|c|}{ Additional Requirements: } \\
\hline Height & \multicolumn{8}{|c|}{$\begin{array}{l}\text { Height restrictions vary throughout the former City of Toronto. See Appendix 'B' } \\
\text { of the Zoning By-law }\end{array}$} \\
\hline $\begin{array}{l}\text { Min. lot frontage } \\
\text { (width) }\end{array}$ & \multicolumn{8}{|c|}{$\begin{array}{l}6.0 \mathrm{~m} \text { in all residential zones. Other restrictions may apply. See Appendix 'B' of } \\
\text { the Zoning By-law }\end{array}$} \\
\hline One house per lot & \multicolumn{8}{|c|}{ Only one house is permitted per lot, and no house behind another } \\
\hline $\begin{array}{l}\text { Setback to } \\
\text { Adjacent } \\
\text { Buildings }\end{array}$ & \multicolumn{8}{|c|}{$\begin{array}{l}\text { For most Residential buildings: the zoning by-law requires a setback to adjacent } \\
\text { buildings of } 1.2 \text { meters for adjacent building walls with any openings, and } 0.9 \\
\text { meters for adjacent building walls without openings } \odot \text { City of Toronto, 1998-2014 }\end{array}$} \\
\hline
\end{tabular}




\section{Appendix $\mathrm{H}$ - Existing house}

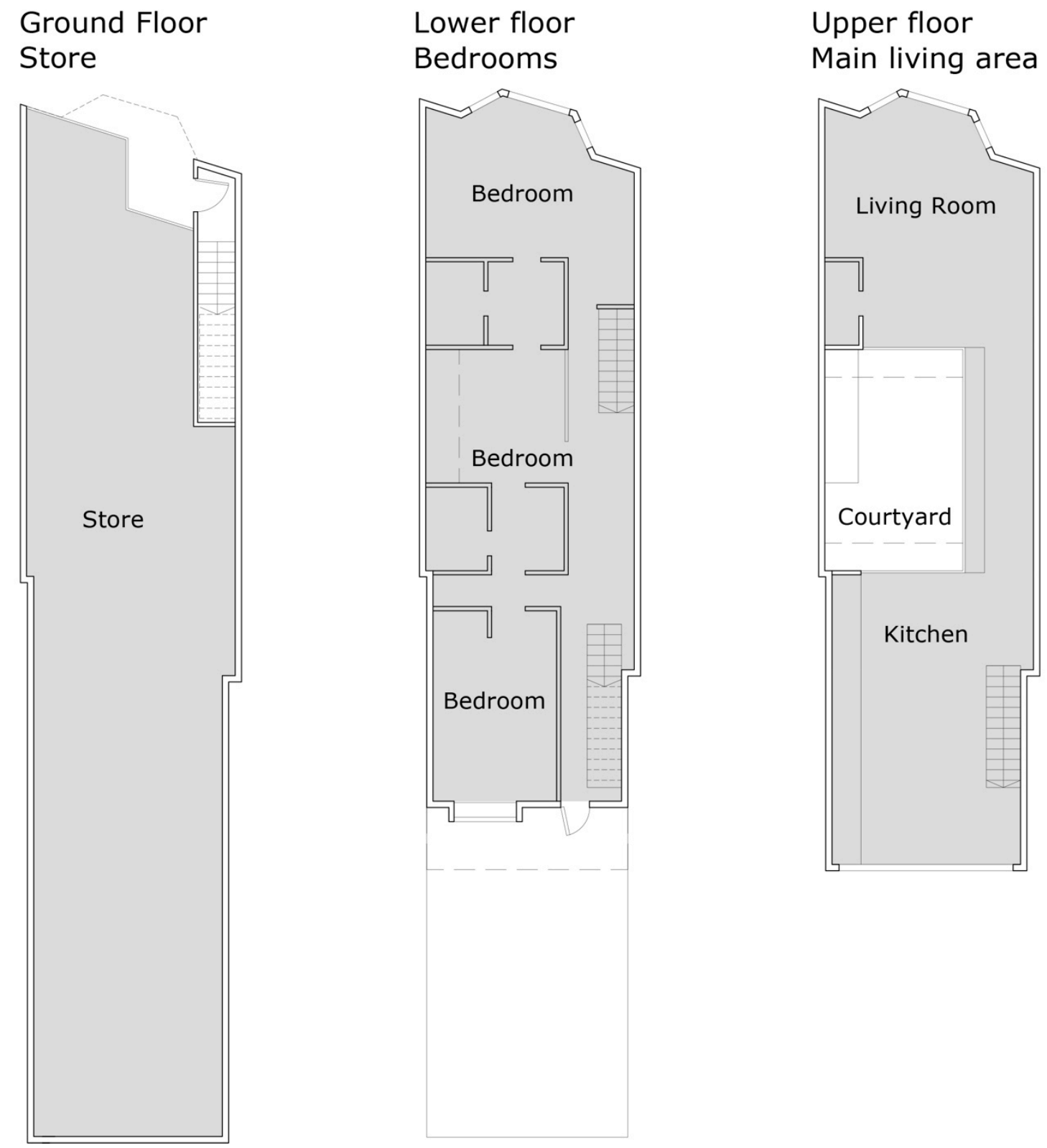

Current house plans 


\section{Appendix I - Illuminance increase vs. Heating and cooling energy increase}

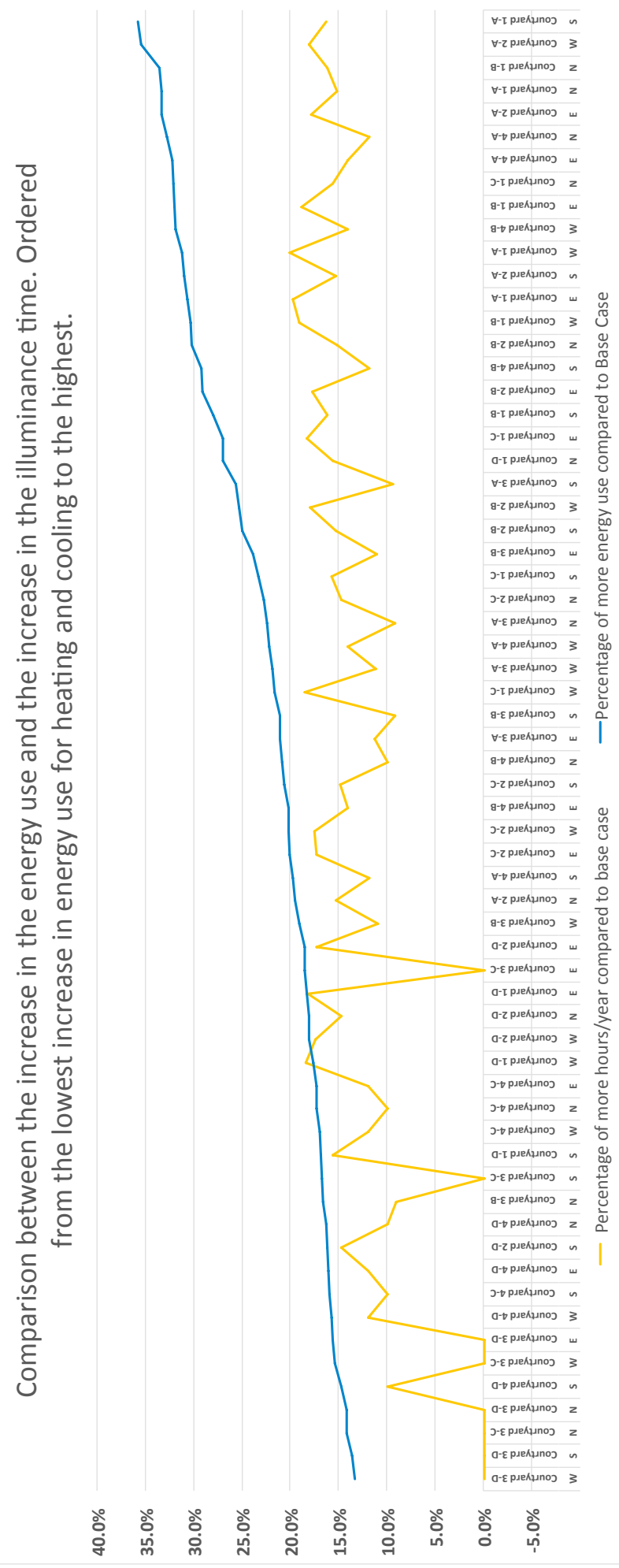




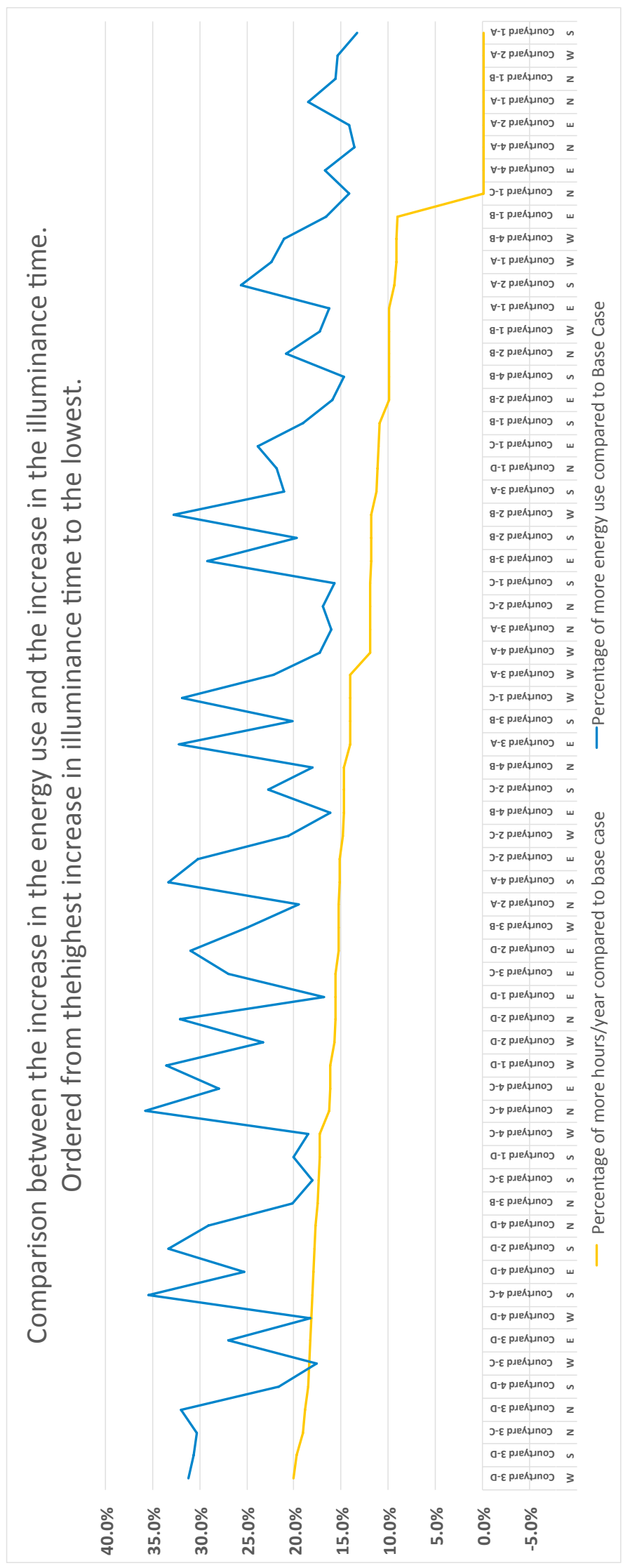




\section{References}

Aldawoud, A. (2008). Thermal performance of courtyard buildings. Energy and Buildings, 40(5), 906-910. doi:10.1016/j.enbuild.2007.07.007

Blitzer, W. F. (n.d.). Light in Design - An Application Guide.

Borbe, A. B. (1988). Planning and Building in Northern Cities: The Case of Hammerfest. In Jorma Mänty \& Norman Pressman (Eds.), Cities Designed for Winter. (pp. 251266). Helsinki: Building Book.

City of Toronto. (n.d.). Zoning bylaw 438-86. Toronto Building. Retreived on June 13th, 2014 from

http://www1.toronto.ca/wps/portal/contentonly?vgnextoid=6dac3f8a7d6c1410Vg nVCM10000071d60f89RCRD\&vgnextchannel=75461 ba53b450410VgnVCM100000 71d60f89RCRD

City of Toronto. [49h-22.dwg]. Toronto, ON: City of Toronto Property Data Maps (Febreuary22nd, 2010). Available: GMDC Ryerson Univeristy <http://library.ryerson.ca/gmdc/madar/geo-data/search/toronto/> (Accessed October 1, 2014).

Census Dictionary - Canada. (2012) (p. 166). Row House definition. doi:98-301X2011001

CMHC Canadian Mortgage and Housing Corporation. (2014). CHS-Demography 2013. Retrieved from http://www.cmhcschl.gc.ca/odpub/esub/64693/64693_2014_A01.pdf?fr=1402523963589

Crawley, D., et al. (2004). EnergyPlus: New, capable, and linked. Journal of Architecture and Planning Research 21(4), 292 - 302.

Culjat, B. (1988). Climate Responsive Social Space: A Scandinavian Perspective. In Jorma Mänty \& Norman Pressman (Eds.), Cities Designed for Winter Climate (1st ed., pp. 346-363). Helsinki: Building Book.

Cuttle, C. (2003). Ligthing by design. Oxford: Architectural Press.

De la Riva, R. (1997). "Plex" Housing A Renewed tradition. Ottawa. 
Dwell (Unknown drafter). (2014). [Drawings from a house located in Toronto]. Family Function. Dwell Magazine, Vol. 14 Issue 04 (pp. 84-89). Dwell Media, LLC. San Francisco.

EnergyPlus. (US Department of Energy). (2014). EnergyPlus Energy Simulation Software Weather data retrieved June $1^{\text {st }}, 2014$ from http://apps1.eere.energy.gov/buildings/energyplus/weatherdata_about.cfm

Edwards, L., \& Torcellini, P. (2002, July). A Literature Review of the Effects of Natural Light on Building Occupants. Golden, CO: National Renewable Energy Laboratory.

EnergyPlus. (US Department of Energy). (2013). The Encyclopedic Reference to EnergyPlus Input and Output. Retrieved on October 2014 from http://apps1.eere.energy.gov/buildings/energyplus/

Friedman, A. (2010). Narrow Houses. New Directons in Efficient Design. New York: Princeton Architectural Press.

Friedman, A. (2012). Town and Terraced Housing for Affordability and Sustainability. Londong and Ney York: Routledge.

Fortin, G. (Architect). (2014). [Untitled photograph from the interior space of a house]. Retrieved on June $20^{\text {th }}, 2014$ from www.gervaisfortin.com

Guzowski, M. (2010). Towards Zero Energy Architecture - New Solar Design. London: Laurence King.

Jermyn, D. (2014). Deep energy retrofits: Toronto's urban single family housing. MASc Graduate Building Science. Ryerson University. Toronto.

Klein, J. (1971). The Row House - Its Place in the Urban Community. Ottawa: The Canadian Housing Design Council.

Kpanen, M. (Photographer), Alvar Aalto Museum. (n.d.). [Untitled photograph part of the section The building runs round the courtyard], Retrieved October 17th 2014, from: http://www3.jkl.fi/saynatsalo/townhall/en-341.htm

Lawson, M.B.M. (Commissioner of Planning City of Toronto). (1963). Supplementary Report on Town Housing.

Liu, D. (1988). A Review of Harbin's Challenge to Winter. In N. Mänty, Jorma. Pressman (Ed.), Cities Designed for Winter Climates (1st ed., pp. 113-129). Helsinki: Building Book. 
Mänty, J. (1988). Cities Designed for Winter. In Jorma Mänty \& Norman Pressman (Eds.), Cities Designed for Winter. Helsinki: Building Book.

Moser, L. (Photographer), Alvar Aalto Museum. (n.d.). [Untitled photograph part of the section The building ages and adapt], Retrieved October 17th 2014, from: http://www3.jkl.fi/saynatsalo/townhall/en-464.htm

Muhaisen, A. S. (2006). Shading simulation of the courtyard form in different climatic regions. Building and Environment, 41(12), 1731-1741. doi:10.1016/j.buildenv.2005.07.016

Muhaisen, A. S., \& Gadi, M. B. (2006). Effect of courtyard proportions on solar heat gain and energy requirement in the temperate climate of Rome. Building and Environment, 41(3), 245-253. doi:10.1016/j.buildenv.2005.01.031

National Research Council Canada. (2014). [Sunrise and sunset time calculation]. Retrieved on January 3rd, 2014 from http://www.nrc-cnrc.gc.ca/eng/services/sunrise/

Natural Resources Canada. (2013a). Choosing and Using Appliances with Energuide. Natural Resources Canada. (2013b). Phase-out of Inefficient LIGHT best 8 Bulbs. Retrieved on April 1 ${ }^{\text {st }}, 2014$ from http://www.nrcan.gc.ca/node/6851.

Numerical Logics (Canadian Weather for Energy Calculations - CWEC). (1999). Users Manual and CD-ROM. Downsview, Ontario: Environment Canada.

Oldham, D. J., \& Mohsen, E. A. (1979). A Model Investigation of the Acoustical Performance of Courtyard Houses with Respect to Noise from Road Traffic. Apllied Acoustics, (12).

Onion Flats (Architecture firm). (n.d.). [Photographs of row houses from the architecture firm Onion Flats]. Retrieved on June 20th, 2014 from http://www.onionflats.com/\#/Work/

Ontario Ministry of Municipal Affairs and Housing. (2006). Ontario Building Code.

Ontario Ministry of Municipal Affairs and Housing. (2009). (2012 update).Ontario Building Code Supplementary Standard 12, 20.

Özkan, S. (2005). Foreword - Courtyard: A Typology that symbolises a culture. In B. Edwards, M. Sibley, M. Hakmi, \& P. Land (Eds.), Courtyard Housing. Past, Present and Future (p. 373). New York: Taylor \& Francis. 
Petruccioli, A. (2006). The Courtyard House: Typological variations. In B. Edwards, M. Sibley, M. Hakmi, \& P. Land (Eds.), Courtyard Housing. Past, Present and Future. New York: Taylor \& Francis.

Pfeifer, G., \& Brauneck, P. (2008). COURTYARD Houses: A Housing Typology. Boston: Birkhäuser.

Raydan, D., Ratti, C., \& Steemers, K. (2003). Building form and environmental performance: archetypes, analysis and an arid climate. Energy and Buildings, 35(1), 49-59. doi:10.1016/S0378-7788(02)00079-8

Shapton, D. (Photographer). (2014, March). [Untitled photograph from a house located in Toronto. Placed in the article Family Function]. DWELL Magazine (pp. 84-89).

Snøhetta (Architectural firm). (n.d.). [Design of the ZEB Pilot House, Larvik, Norway. 2014 from Snøhetta], Retrieved on January $3^{\text {rd }}, 2014$ from http://snohetta.com/project/188-zeb-pilot-house

Taleghani, M., Tenpierik, M., \& van den Dobbelsteen, A. (2014). Energy performance and thermal comfort of courtyard/atrium dwellings in the Netherlands in the light of climate change. Renewable Energy, 63, 486-497. doi:10.1016/j.renene.2013.09.028

Teittinen, U. (Drafter), Alvar Aalto Museum Archives. (n.d.). [Drawing adapted from the section The building ages and adapt], Retrieved October 17th 2014, from: http://www3.jkl.fi/saynatsalo/townhall/en-4.htm

Ward, P. (1999). A History of Domestic Space: Privacy and the Canadian Home. Vancouver: UBC Press.

Zirnhelt, H. E. 2013. Using calibrated simulation to quatify the energy savings from residential passive solar design in Canada. MASc Graduate. Ryerson University. Toronto. 